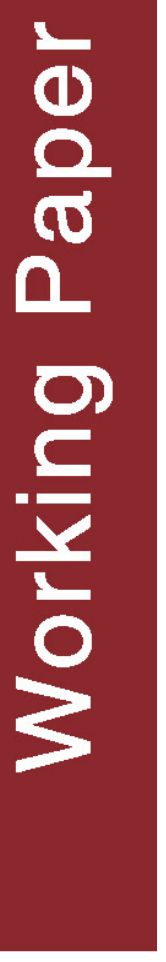

Widianto, Didik Suprayogo, Sudarto, Iva Dewi Lestariningsih 



\section{Implementasi Kaji Cepat Hidrologi (RHA) di Hulu DAS Brantas, Jawa Timur}

Widianto, Didik Suprayogo, Sudarto, Iva Dewi Lestariningsih 


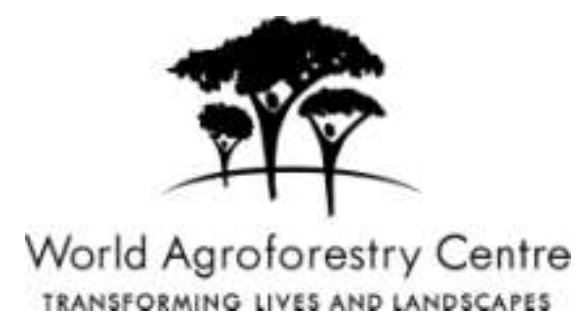

\section{Correct citation:}

Widianto, Suprayogo D, Sudarto, and Lestariningsih ID. 2010. Implementasi Kaji Cepat Hidrologi (RHA) di Hulu DAS Brantas, Jawa Timur. Working paper nr.121. Bogor, Indonesia. World Agroforestry Centre.133p. DOI: 10.5716/WP10338.PDF.

Titles in the Working Paper Series aim to disseminate interim results on agroforestry research and practices and stimulate feedback from the scientific community. Other publication series from the World Agroforestry Centre include: Agroforestry Perspectives, Technical Manuals and Occasional Papers.

Published by the World Agroforestry Centre

ICRAF Southeast Asia Regional Office

Jl. Cifor, Situ Gede, Sindang Barang, Bogor 16115

PO Box 161, Bogor 16001, Indonesia

Tel: +622518625415

Fax: +62 2518625416

Email: icraf-indonesia@ cgiar.org

Website: www.worldagroforestrycentre.org/sea

(C) World Agroforestry Centre 2010

Working Paper nr 121

Photos: RHA Team Universitas Brawijaya

Maps: RHA Team Universitas Brawijaya

Geographycal data: RHA Team Universitas Brawijaya

The views expressed in this publication are those of the author(s) and not necessarily those of the World Agroforestry Centre.

Articles appearing in this publication may be quoted or reproduced without charge, provided the source is acknowledged.

All images remain the sole property of their source and may not be used for any purpose without written permission of the source. 


\section{About the authors}

\section{Widianto}

Department of Soil Science, Faculty of Agriculture, Universitas Brawijaya Email:wied.widianto@telkom.net

\section{Didik Suprayogo}

Department of Soil Science, Faculty of Agriculture, Universitas Brawijaya Email: suprayogo@brawijaya.ac.id

\section{Sudarto}

Department of Soil Science, Faculty of Agriculture, Universitas Brawijaya

\section{Iva Dewi Lestariningsih}

Department of Soil Science, Faculty of Agriculture, Universitas Brawijaya Email: id.lestariningsih@gmail.com 


\section{Abstract}

Sumber Brantas Watershed is one out of five sub catchments of the Upper Brantas River, situated in Batu District, East Java, Indonesia and covering an area about $174 \mathrm{~km}^{2}$. Recently, the hydrology of the watershed was considered to be degraded in terms of the quality and quantity of water yield. Fast floods were more often during the rainy seasons, while droughts were more severe during the dry seasons. Much spring water dried out in the dry seasons and two-third of them dried out permanently in the last decade. The condition was often related to the rapid change of landuse in the watershed. The natural forest and agroforestry gardens were converted into rain fed agriculture. Analysis on land sat images from 1989 and 2002 showed that 3,702ha of natural forest and 1,153ha of agroforestry gardens has disappeared. Further analysis showed that the area of rain fed agriculture, settlements and shrubs were increasing during that period. This most likely related to the socio-economics conditions of local community as well as the variability of stakeholders' perception in best watershed management planning and practices.

The Rapid Hydrological Appraisal (RHA) implementation at the Sumber Brantas Watershed aimed to test the methodology, which is claimed to be rapid and cheap, and to validate the GenRiver Model - an important component of the methodology, to learn the stakeholders' perceptions on the watershed management and to build an understanding among stakeholders in order to select the best watershed management practices.

RHA itself is claimed as a rapid and cheap methodology that is important in the early steps of an environmental service activity. The method consists of three stages i.e. scooping, awareness and identifying partners. Scooping and identifying partners were reflected from information and data collection about study site, hydrological issues, and stakeholders who involved in the watershed management.

Watershed stakeholders consisted of three groups i.e. local community, policy makers and researchers or facilitators. Knowledge, perception and experiences from each group of stakeholders used to be called as LEK (Local Ecological Knowledge), PEK (Policy Ecological Knowledge), and MEK (Modeler Ecological Knowledge). Meanwhile, the data collection including spatial data, participatory landscape analysis, local and political knowledge assessment about watershed ecology, data analysis related on hydrological condition, and the stakeholders meeting constituted as a package of community awareness about watershed management at the study site.

In general, the perceptions on watershed hydrology among the three groups of stakeholders in Sumber Brantas Watershed (i.e. PEK, MEK and LEK) tend to be similar. The important hydrological issues in the Sumber Brantas Watershed are about flash-floods and drought, 
decrease of the number of springs in the watershed as well as their discharge, the decrease of water quality, and the more intensive soil loss due to erosion and landslide.

The three groups of stakeholders agreed that the discharge of main river (Upper Brantas River) depends on seasonal rainfall variability. During rainy seasons, the river discharge tends to be very high, while in dry seasons it dries up. The discharge ratio between rainy and dry season is high and tends to increase annually. The fluctuations of river discharge and the floods frequency is related to the percentage of forest area in the upstream. The above perception is supported by modelers (MEK) as indicated by the calculated discharge through simulation model under various scenarios of land cover areas. The amplitude of maximum and minimum discharges is affected by percentage of forest area in the watershed. Reduction of forest area in the watershed will increase the amplitude of maximum and minimum discharge. The simulation also shows extremely high discharges or flooding following heavy rainfall events.

LEK and PEK groups stated that the decreasing of the number of springs as well as the discharge of the springs in the watershed was affected by deforestation. The deforestation will reduce the recharge area, so that the absence of forest will affect the discharge of the springs nearby. However, the MEK group mentioned that the most relevant recharge area of a spring is not necessarily adjacent to the spring, dependent to geologic and topographic conditions of the area. The three groups perceived that the decrease of the water quality in the watershed is mainly due to sedimentation and water pollution. Sediment in the river is mostly coming from erosion of agricultural and landslides on road-cuts, river-banks and steep lands. Pollutants in the main Brantas River is usually coming from the waste of human activity along the river, such as intensive agriculture, agriculture-based industry, and tourism activities. The agriculture-based industry along the Sumber Brantas watershed that produced pollutants are mushroom and flowers growers, intensive small-scale horticulture practices (fruits, vegetables, and flowers), and small-scale food and beverage industries. Meanwhile, the tourism activity includes hotel and restaurant business. The LEK group believed that the soil material transported into the river is mostly coming from the forest-production area that has been converted into agriculture lands by local farmers (known as pesanggem). Usually, they grow rain fed vegetables such as carrot, potato, cabbage in the steep slopes without proper management. The group also thought that the conversion of forest into agriculture land will trigger landslide evidence on the steep slopes. They were quite sure that the absence of tree vegetation on the steep lands was the major cause of landslides and flooding. Actually, the perception of the PEK and MEK group on the erosion and landslide issues are not quite different from LEK group. However, they emphasized that slope is more prominent factor triggering landslides than the absence of trees. 
Comparing the simulated discharge using the GenRiver model to the actual field measurement shows a poor relation. The measured discharge data collected by PJT 1 (Perum Jasa Tirta I) seems to have unexpected trends that cannot be explained well by the available supporting data such as rainfall data. However, the simulated discharge upon some landuse scenarios indicates some acceptable preferences compared to the actual field condition.

In conclusion, the similarity of perception among stakeholders in the watershed will give chance to find the best management plan and practices in the near future. But there is still a problem to bring the stakeholders to sit together discussing their opinion, perception and hope on the future of the watershed. An appropriate system and mechanism of coordination and communication among stakeholders is certainly needed to build better understanding of the watershed. Environmental service mechanism can be potentially developed in Sumber Brantas watershed, since the early initiative has been explored and practiced by some stakeholders, such as Perum Jasa Tirta I.

\section{Keywords}

Environmental services, hydrological, modeling, local knowledge, watershed 


\section{Acknowledgements}

Working paper ini disusun oleh Tim RHA dari Departemen Ilmu Tanah, Fakultas Pertanian, Universitas Brawijaya bekerja sama dengan ICRAF SEA dalam Proyek Trees in multi-Use

Landscapes in Southeast Asia (TUL-SEA) yang didanai oleh Federal Ministry for Economic Cooperation and Development (BMZ) Germany. 


\section{Contents}

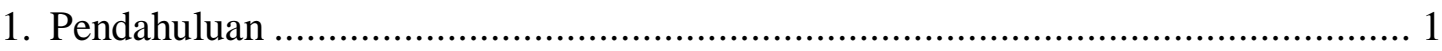

1.1. Assesmen hidrologi di DAS Sumber Brantas .................................................. 1

1.2. Tujuan dan keluaran................................................................................. 2

1.3. Pemeliharaan Fungsi DAS Sumber Brantas melalui Mekanisme Imbal Jasa.... 3

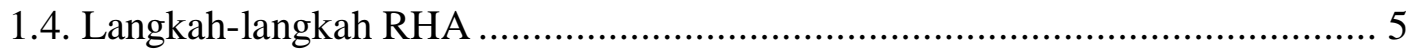

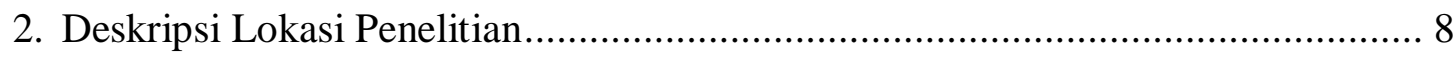

2.1. Studi Dokumentasi Data/ Laporan ...................................................... 8

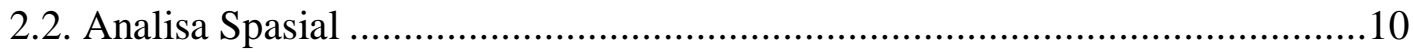

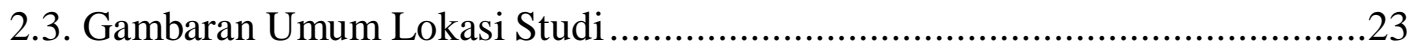

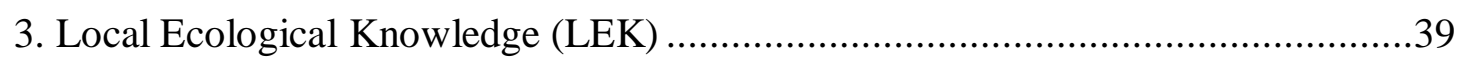

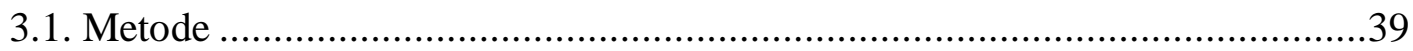

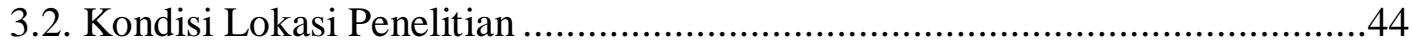

3.3. Kondisi Lahan di Kawasan DAS Mikro Kekep ..........................................48

3.4. Kondisi Aktual DAS Mikro Talun ............................................................52

3.5. Pengetahuan Lokal Hidrologi dan Pengelolaan DAS .....................................54

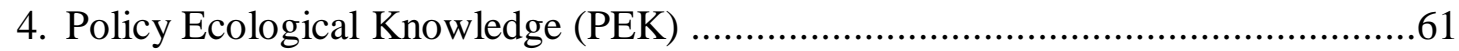

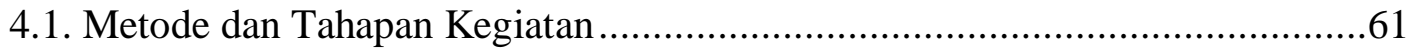

4.2. Persepsi dan Pengetahuan Para Pengambil Kebijakan terhadap Fungsi DAS ..65

4.3. Isu Hidrologi Menuju DAS yang Sehat ....................................................... 74

4.4. Evaluasi Pengalaman Stakeholder dalam membangun integrasi komunikasi

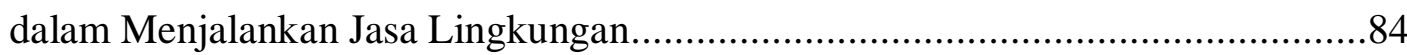

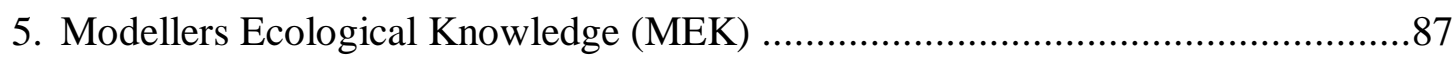

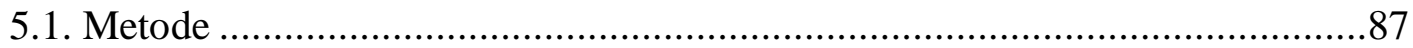

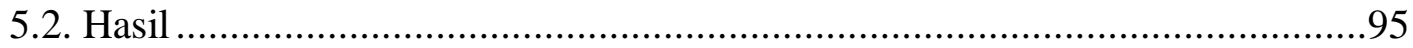

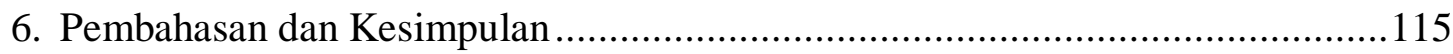

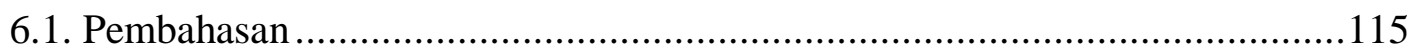

6.2. Penerapan Metodologi RHA di DAS Sumber Brantas .................................118

6.3. Peluang Pembayaran Jasa Lingkungan di DAS Sumber Brantas...................119

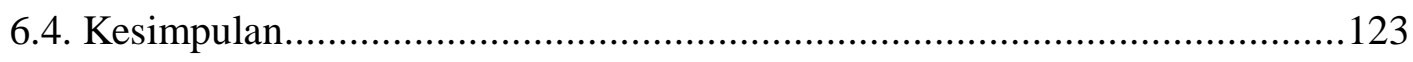

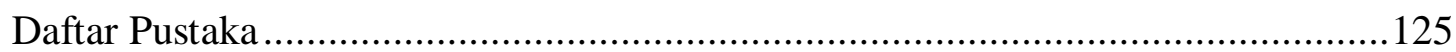




\section{Pendahuluan}

\subsection{Assesmen hidrologi di DAS Sumber Brantas}

DAS Sumber Brantas dikenal juga sebagai DAS Sumber Brantas, karena di kawasan ini terdapat beberapa mata air yang dinyatakan sebagai titik awal aliran Kali Brantas. Ada pihak-pihak yang menyebutkan bahwa DAS Sumber Brantas meliputi beberapa Sub-DAS diantaranya adalah SubDAS Sumber Brantas, SubDAS Amprong, SubDAS Bango, SubDAS Lesti, SubDAS Metro, SubDAS Lahor dan SubDAS Lemon. Total luas seluruh DAS Sumber Brantas $200 \mathrm{~km}^{2}$, dan semuanya merupakan daerah tangkapan air hujan dari Waduk Karangkates.

DAS Sumber Brantas adalah salah satu DAS paling kritis dari sekitar 29 DAS yang ada di Jawa Timur. Hampir separuh dari wilayah DAS ini termasuk dalam kategori lahan kritis (BKPH XI, 2006). Isu lingkungan yang paling menonjol di kawasan ini adalah (a) alih-guna lahan dari hutan menjadi tanaman sayur-sayuran, (b) penurunan kuantitas dan kualitas air, dan (c) degradasi lahan.

Perubahan penggunaan lahan (alih-guna lahan) di DAS Sumber Brantas sebenarnya sudah berlangsung sejak awal abad 20, tetapi terjadi secara lambat (gradual). Alih-guna lahan semakin cepat terjadi pada tahun 1960-an dan mencapai puncaknya pada akhir tahun 1990-an, tepatnya tahun 1998-1999 ketika terjadi situasi peralihan yang dikenal dengan masa reformasi. Perbandingan citra satelit kawasan ini yang diambil pada tahun 1991, 2001 dan 2005 menunjukkan adanya pengurangan tutupan lahan sebagai hutan alam dan hutan tanaman (produksi) dan meningkatnya luas penggunaan lahan untuk perkebunan, tegal, semak belukar dan pemukiman. Alihguna lahan hutan menjadi tegalan, yakni lahan tadah hujan ditanami sayuran, sangat berpotensi mengalami kerusakan akibat erosi. Hal ini juga sudah dipahami oleh masyarakat setempat (Studi Detail Konservasi Sub DAS Sumber Brantas, 2006). Sejak tahun 1970-an usaha tani hortikultura (sayuran dan bunga) merupakan sumber penghasilan utama sebagian besar petani di Kota Batu. Pada akhir tahun 1990-an terjadi penebangan hutan besarbesaran dimana sebagian besar dijadikan tegalan dan ditanami sayuran.

Penurunan kuantitas dan kualitas air di DAS Sumber Brantas diindikasikan dari seringnya terjadi banjir dan kekeringan di wilayah Kota Batu maupun bagian hilirnya. Banjir mulai terjadi pada tahun 2000, selanjutnya terjadi hampir setiap musim penghujan dan yang paling besar terjadi pada tahun 2004. Indikator lainnya adalah mengecilnya debit sebagian besar mata air di kawasan ini, dan bahkan dua per tiga jumlah mata air mengering atau mati selama satu dekade terakhir. Penurunan debit mata air juga sudah dirasakan dan dipahami oleh masyarakat setempat. Apabila sepuluh tahun lalu kebutuhan air warga Dusun Kekep (Tulungrejo) dapat 
dicukupi dari sebuah sumber air saja, saat ini air yang diperoleh dari empat sumber air ternyata masih belum mencukupi kebutuhan warga dusun tersebut (Studi Kelestarian Sumber-sumber Air di Kota Batu, 2006).

Kerusakan lahan diyakini oleh banyak pihak berawal dari proses pembukaan lahan hutan yang memiliki kelerengan curam untuk ditanami tanaman semusim terutama sayuran. Kehilangan tanah akibat erosi di beberapa kawasan DAS Mikro ditaksir sebesar 1,500 ton/ha/tahun.

Permasalahan sumberdaya alam di DAS Sumber Brantas selain disebabkan oleh faktor ekonomi juga oleh faktor sosial yang memicu terjadinya konflik-konflik di tingkat masyarakat maupun pemerintahan. Perbedaan cara pandang terhadap upaya pengelolaan sumberdaya alam di DAS ini jika dibiarkan akan memperparah kerusakan sumberdaya alam di wilayah ini. Oleh karena itu diperlukan upaya-upaya pemahaman bersama oleh seluruh stakeholder yang terkait tentang keadaan DAS Sumber Brantas serta apa yang tengah terjadi di sub DAS ini. Untuk mewujudkan hal itu perlu mengajak seluruh stakeholder agar dapat bersama-sama mencermati dan memahami kondisi dan permasalahan yang sedang terjadi di sub DAS Sumber Brantas serta mencarikan solusi dari permasalahan tersebut.

Untuk membangun komunikasi yang efektif antar stakeholder sehingga dapat menghasilkan pemahaman yang baik terhadap kondisi dan permasalahan DAS serta alternatif solusi, diperlukan alat-alat dan media untuk membantu proses dialog tersebut, khususnya dalam memahami kondisi dan perilaku DAS. Bermacam metode dapat dipergunakan untuk mengidentifikasi kondisi hidrologi secara cepat di lapangan, salah satunya adalah metode Rapid Hydrological Appraisal (RHA). Metode ini telah digunakan di beberapa wilayah antara lain yaitu di DAS Kapuas Hulu, DAS Talau, dan Way Besai dengan hasil cukup memuaskan. Oleh sebab itu instrumen RHA ini dipilih untuk diterapkan dalam proses pengelolaan DAS Sumber Brantas di mana kondisi hidrologi DAS merupakan isu utama. Implementasi RHA diharapkan dapat memberikan pemahaman dan cara pandang baru bagi seluruh stakeholder terhadap kondisi dan pengelolaan DAS Sumber Brantas.

\subsection{Tujuan dan keluaran}

\subsubsection{Tujuan Penelitian}

Tujuan kegiatan implementasi RHA di DAS Sumber Brantas adalah:

1. Melakukan uji penerapan metode RHA di DAS Sumber Brantas.

2. Menyamakan cara pandang dan persepsi seluruh stakeholder di DAS Sumber Brantas tentang kondisi dan pengelolaan DAS Sumber Brantas.

3. Melakukan uji validasi terhadap model GenRiver. 


\subsubsection{Keluaran yang Diharapkan}

1. Hasil yang diharapkan dari kegiatan implementasi RHA di DAS Sumber Brantas adalah:

2. Saran dan masukan tentang penerapan metode RHA yang sudah teruji di DAS Sumber Brantas.

3. Tumbuhnya persepsi yang sama diantara seluruh komponen atau stakeholder di DAS Sumber Brantas terhadap upaya pengelolaan di wilayah ini

4. Masukan dan saran terhadap penggunaan model GenRiver.

\subsection{Pemeliharaan Fungsi DAS Sumber Brantas melalui Mekanisme Imbal Jasa}

Masalah hidrologi DAS Sumber Brantas sebenarnya sudah dirasakan sejak awal tahun 1980-an, terutama oleh Proyek Brantas (sekarang Perum Jasa Tirta), yang membangun dan mengelola beberapa bendungan di sepanjang Kali Brantas sejak tahun 1970-an. Sementara masalah hidrologi di DAS Brantas sendiri sudah jauh lebih dulu muncul, sehingga mulai tahun 1960an sudah mulai direncanakan dan dibangun beberapa bendungan untuk mengendalikan banjir di sepanjang Kali Brantas.

Permasalahan yang dihadapi Proyek Brantas adalah besarnya tingkat sedimentasi di wadukwaduk akibat erosi yang terjadi di bagian hulu, termasuk DAS Sumber Brantas, yang jauh lebih besar dari yang diperkirakan. Pada saat itu masih belum dirasakan adanya masalah yang terkait dengan fluktuasi debit air. Upaya-upaya pencegahan erosi sudah dilaksanakan oleh beberapa institusi pemerintah, termasuk inisiatif dari Proyek Brantas yang selanjutnya diserahkan kepada PJT 1 sebagai pengelola. Upaya penghijauan dan reforestasi, bantuan kepada masyarakat (petani) untuk membuat bangunan konservasi (teras, drop structure, gully plug, saluran pembagi, penguat teras dsb), serta mendorong petani untuk menerapkan upaya konservasi tanah dan air dalam praktek pertanian mereka.

Upaya-upaya yang sudah menggunakan daya dan dana sangat besar itu ternyata tidak memberikan hasil seperti yang diinginkan. Sedimentasi di waduk tetap tinggi sehingga ada perkiraan terjadi penurunan kapasitas efektif waduk dibanding kapasitas yang direncanakan. Hasil studi JICA pada tahun 1998 dan survei yang dilakukan PJT antara tahun 1992-2003 menunjukkan bahwa kapasitas tampungan total waduk Sutami tinggal 50\% dari yang direncanakan semula (PJT I, 2005). Dalam kaitan ini, PJT 1 dan PT PJB (Pembangkitan JawaBali) adalah stakeholder yang berkepentingan langsung terhadap upaya perbaikan konservasi tanah dan air di DAS Sumber Brantas. Akibat pendangkalan waduk juga secara berantai dirasakan oleh masyarakat luas, antara lain melalui ketersediaan listrik (PLN). Dengan semakin 
berkembangnya aktivitas masyarakat di sepanjang Kali Brantas, semakin banyak pula aktivitas yang bergantung dari ketersediaan air sungai ini baik jumlah (kuantitas), kualitas, maupun kontinyuitasnya. Pemanfaatan air sungai ini antara lain untuk irigasi (sawah seluas $340.000 \mathrm{ha}$ ), industri (ratusan pabrik dan perusahaan kecil sampai besar), bahan baku air minum PDAM sebanyak 300 juta $\mathrm{m}^{3}$, menghasilkan enerji listrik 1 milliar $\mathrm{kWh} /$ tahun, dsb (PJT 1, 2006).

Kondisi hidrologi DAS Sumber Brantas sesudah tahun 2000 ternyata tidak semakin baik tetapi justru sebaliknya semakin kritis. Alih-guna lahan hutan menjadi lahan budidaya pertanian tidak saja memicu peningkatan erosi dan sedimentasi, tetapi juga mengakibatkan banjir dan kekeringan. Semakin banyak warga masyarakat tergantung dan terlibat dalam pengelolaan tanah/lahan di kawasan hulu sehingga permasalahan DAS Sumber Brantas semakin kompleks. Permasalahan pengelolaan DAS Sumber Brantas yang melibatkan ribuan warga masyarakat Kota Batu, Perum Perhutani, Tahura R. Soerjo dan Pemerintah Kota Batu ternyata tidak mudah diselesaikan. Salah satu alasan yang sering diungkapkan adalah minimnya reward terhadap upaya-upaya pengelolaan lahan dalam bentuk perhatian/ penghargaan dan dukungan dana. Kondisi terkini mengharuskan semua pihak baik masyarakat di hulu, tengah maupun hilir Kali Brantas untuk memikul tanggung jawab bersama dalam memelihara DAS dengan melakukan pengelolaan DAS secara tepat. Bentuk tanggung jawab setiap stakeholder perlu dirumuskan secara adil sesuai dengan tindakan/aksi yang bisa diperankan oleh masing-masing pihak. Salah satu upaya yang ditawarkan adalah mekanisme imbal-jasa lingkungan (Payment of Environmental Services - PES). Mekanisme yang sudah diterapkan di beberapa negara, juga sudah diujicobakan di beberapa tempat (DAS) di Indonesia. Mekanisme ini juga sudah pernah diteliti dan diujicobakan dalam skala kecil di DAS Brantas (Gunawan et al., 2005).

Hasil studi LP3ES bersama YPP dan PJT I (Gunawan et al., 2005) menunjukkan adanya potensi yang cukup besar untuk memperbaiki kondisi DAS Brantas melalui pengelolaan DAS yang disukung oleh mekanisme imbal-jasa lingkungan. Potensi ini ditanggapi secara positif oleh masyarakat di Jawa Timur, sehingga Pemerintah Provinsi Jawa Timur bersama DPRD dan masyarakat Jawa Timur sudah mulai menyiapkan Peraturan Daerah (Perda) mengenai mekanisme imbal-jasa lingkungan ini. Konsep Perda ini sedang dibahas secara intensif dengan melibatkan masyarakat luas (LSM, Perguruan Tinggi, petani, kalangan industri, pengusaha, dsb) sejak tahun 2007, namun sampai saat ini masih belum selesai.

Berdasarkan situasi, kondisi dan kebutuhan DAS Sumber Brantas, serta dengan memperhatikan konteks yang lebih luas (DAS Brantas dan Provinsi Jawa Timur), maka dapat disimpulkan bahwa mekanisme imbal jasa lingkungan sangat potensial untuk dikembangkan sebagai salah satu pilar pengelolaan DAS Sumber Brantas. Jika hal ini menjadi kesepakatan bersama untuk dilaksanakan maka masih banyak hal-hal yang perlu disiapkan oleh semua pihak yang terlibat di dalamnya. Dalam hal inilah RHA yang dikembangkan oleh World Agroforestry Centre (ICRAF) diharapkan bisa digunakan untuk membantu mempersiapkan implementasi mekanisme 
imbal jasa lingkungan secara tepat. Berikut ini (dalam Bab 1.4.) diuraikan secara ringkas prosedur RHA yang dikembangkan oleh ICRAF (Jeanes et al., 2006).

\subsection{Langkah-langkah RHA}

Tujuan utama RHA adalah:

1. Untuk memahami kondisi dan pola penggunaan lahan dalam kawasan DAS dan manfaat tata-guna lahan yang bisa dinikmati oleh berbagai pihak, mengidentifikasi alternatif pola tata-guna lahan yang bermanfaat, dan memahami faktor-faktor yang dapat mengendalikan perubahan.

2. Memahami dampak perubahan tata-guna lahan terhadap manfaat/jasa lingkungan sehingga bisa mengidentifikasi para pihak yang berpotensi penjadi pembeli jasa tersebut dan bersedia memberi insentif bagi pihak lain yang bisa mempertahankan dan bahkan meningkatkan manfaat tertentu.

Sasaran utama RHA adalah melakukan tahapan pelingkupan (scoping), sebagai bagian dari proses mempertemukan pihak penjual dan pembeli pada posisi yang setara dalam sebuah perundingan.

Tahapan kegiatan utama RHA dapat diringkas sebagai berikut:

1. Analisis Stakeholder

Kegiatan ini dimulai dari identifikasi lokasi (DAS) secara geografis, mencari dan mengumpulkan dokumen dan literatur, serta menggali informasi dari nara-sumber yang relevan. Berdasarkan jumlah, keragaman dan peran stakeholder, dirancang satu atau lebih pertemuan/ konsultasi kelompok untuk membuat daftar urutan permasalahan serta menganalisis penyebab dan usulan solusi menurut persepsi para pihak.

2. Dokumentasi dan analisa Local Ecological knowledge (LEK).

Pengetahuan lokal (LEK) tentang hutan, landscape (bentang lahan) yang terdiri dari penutupan lahan, air, aliran sungai dan kualitas air akan dieksplorasi, didokumentasikan dan dievaluasi dengan menggunakan suatu pendekatan sistem yang berbasiskan ilmu pengetahuan yang dikembangkan oleh University of Wales (Bangor, UK). Pendekatan ini sebelumnya telah diaplikasikan di beberapa tempat di Indonesia. Stratifikasi atau pengelompokan berdasarkan suku, gender dan kategori dilakukan pada pendekatan ini. Artikulasi yang jelas serta analisis pengetahuan dari kelompok wanita dan golongan masyarakat terpinggirkan lainnya digunakan dalam metode ini. Pengetahuan nonekologi (misalnya kepercayaan masyarakat dan hal-hal yang bersifat tabu) juga akan didokumentasikan dari masyarakat lokal. Training pada tingkat lokal ini akan dilakukan 
oleh staf lapangan. Representasi dari pengetahuan lokal ini akan didiskusikan bersama dalam group sebelum dibandingkan dengan pengetahuan lokal yang lainnya. Tahapan ini dapat dilakukan dalam waktu yang cepat (rapid) sekitar 2-3 minggu tergantung pada sumberdaya serta ketersediaan waktu.

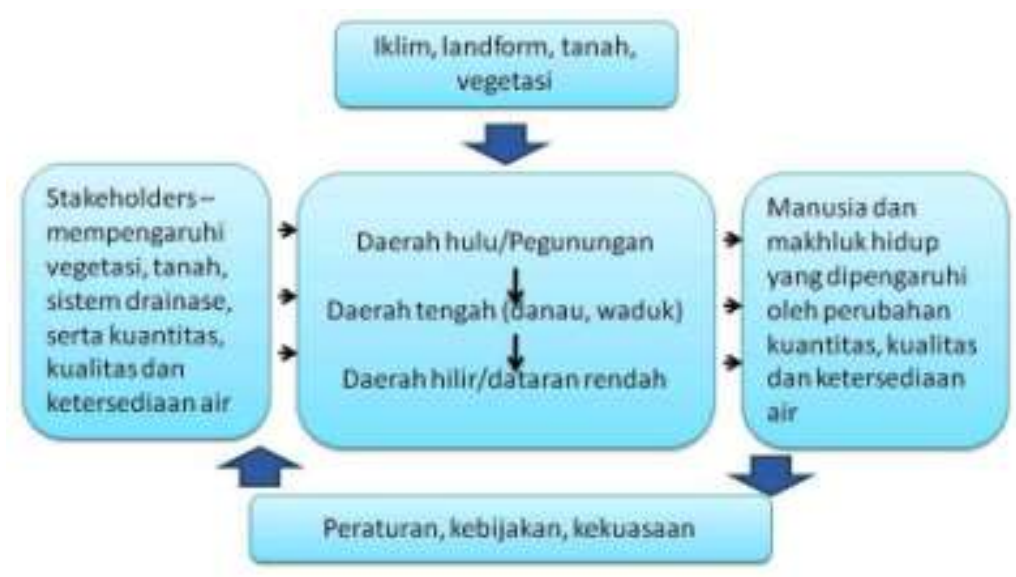

Gambar 1.1. Beberapa bentuk hubungan antara kinerja hidrologi DAS, manusia dan makhluk hidup sebagai pendorong, dan dampak alih-guna lahan

Participatory Landscape Analysis (PALA)

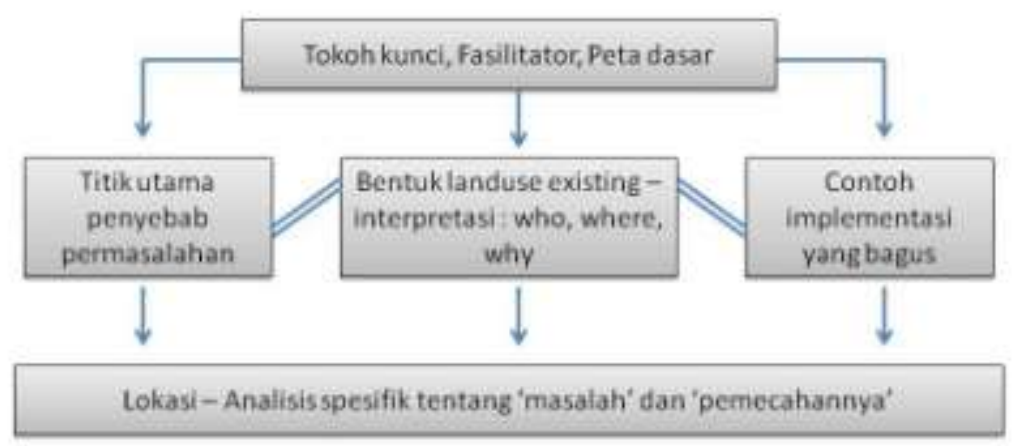

Gambar 1.2. Langkah dalam eksplorasi dan analisis lokal ecological knowledge secara partisipatif

3. Dokumentasi dan analisis pengetahuan ekologi lokal dari public \& policy-shapers.

Pengetahuan lokal tentang hidrologi dari pejabat pemerintahan, stakeholder hilir dan masyarakat umum/urban (PEK) di seluruh lokasi studi akan digali. Interview perorangan dari orang-orang yang mewakili dari stakeholder yang terpilih akan dilakukan untuk dengan mengadopsi pendekatan yang sama dengan pendekatan yang dilakukan dalam proses dokumentasi dan analisis LEK.

4. Spatial analysis.

Untuk mendukung keseluruhan konteks khususnya untuk pengumpulan data geospasial, prosesing dan analisa perlu dilakukan dengan cara yang komprehensif dan terintegrasi. 
Sejalan dengan konsep "penilaian cepat", sedapat mungkin dipilih data sekunder pemrosesan data mentah harus dilakukan untuk mengaplikasikan metode praktis.

Namun demikian, hal tersebut harus tetap menjamin kualitas dari informasi dan data yang dihasilkan.

5. Dokumentasi dan analisa Modeler/ Scientist Ecological Knowledge (MEK).

Penggunaan model water ballance yang dihubungkan dengan data hujan dan berbagai macam skenario penutupan lahan dan landuse untuk memprediksi aliran air ke dalam sungai (inflow to the lake) serta ketersediaan air dari turbin hidroelektrositas.

Perbandingan antara berbagai macam skenario (dengan bermacam tingkat penutupan lahan) dapat menjelaskan "servis lingkungan" sebagai akibat dari bentuk penggunaan lahan, disamping kondisi lain seperti degradasi tanah dan bentang lahan.

Tabel 1.1. Ringkasan Tahapan RHA

\begin{tabular}{|c|c|c|c|}
\hline Tahapan & $\begin{array}{l}\text { Penyedia : penjual jasa } \\
\text { lingkungan }\end{array}$ & $\begin{array}{l}\text { Perantara } \\
\text { (Intermediaries) }\end{array}$ & $\begin{array}{l}\text { Pemanfaat : pembeli jasa } \\
\text { lingkungan }\end{array}$ \\
\hline $\begin{array}{l}\text { Pelingkupan } \\
\text { (Scoping) }\end{array}$ & $\begin{array}{l}\text { - Hal menarik apa yang bisa } \\
\text { ditawarkan buat stakeholder } \\
\text { luar? } \\
\text { - Apa kebutuhan dasar untuk } \\
\text { melakukan konservasi dan } \\
\text { meningkatkan jasa? } \\
\text { - Apa segi positif bagi kita ketika } \\
\text { memelihara fungsi DAS? } \\
\text { - 'Kesadaran untuk membeli' } \\
\text { bagaimana yang kita harapkan? }\end{array}$ & $\begin{array}{l}\text { - 'alat penilai jasa } \\
\text { lingkungan' } \\
\text { - Membawa saling } \\
\text { pengertian, } \\
\text { kriteria dan } \\
\text { indikator }\end{array}$ & $\begin{array}{l}\text { - Di mana lokasi yang dikuasai } \\
\text { masyarakat sangat } \\
\text { memerlukan konservasi? } \\
\text { - Siapa paling efektif } \\
\text { mengendalikan lokasi ini? } \\
\text { - Apa 'wujud kesediaan untuk } \\
\text { mengelola' yang kita inginkan } \\
\text { dan berapa harganya? } \\
\text { - Apakah itu 'bermakna' untuk } \\
\text { kita? }\end{array}$ \\
\hline $\begin{array}{l}\text { Identifikasi } \\
\text { Mitra }\end{array}$ & $\begin{array}{l}\text { - Siapa seharusnya yang diajak } \\
\text { bicara? } \\
\text { - Dokumen apa yang dibutuhkan? }\end{array}$ & $\begin{array}{l}\text { Perantara yang } \\
\text { bisa mengurangi } \\
\text { biaya transaksi }\end{array}$ & $\begin{array}{l}\text { - Siapa yang paling efektif bisa } \\
\text { mewakili aktor lokal? }\end{array}$ \\
\hline Negosiasi & $\begin{array}{l}\text { - Bagaimana menyeimbangkan } \\
\text { antara keterbatasan kemampuan } \\
\text { dengan imbalan? }\end{array}$ & $\begin{array}{l}\text { - Dukungan } \\
\text { Proses }\end{array}$ & $\begin{array}{l}\text { - Bagaimana bisa tahu jika } \\
\text { penjual bisa dipercaya? } \\
\text { - Apakah jaminanbya } \\
\text { (garansinya)? }\end{array}$ \\
\hline $\begin{array}{l}\text { Kesepakatan } \\
\text { Monitoring }\end{array}$ & $\begin{array}{l}\text { - Bagaimana membuat } \\
\text { kesepakatan dengan defectors \& } \\
\text { free riders dalam masyarakat? } \\
\text { - Bagaimana bisa tahu kalau } \\
\text { pembeli puas? }\end{array}$ & $\begin{array}{l}\text { - Monitoring, } \\
\text { evaluasi dan } \\
\text { audit }\end{array}$ & $\begin{array}{l}\text { - Apakah jaminannya? } \\
\text { - Bagaimana bisa memantau } \\
\text { hasil atau keluaran? }\end{array}$ \\
\hline
\end{tabular}




\section{Deskripsi Lokasi Penelitian}

\subsection{Studi Dokumentasi Data/ Laporan}

Dokumen-dokumen yang berhubungan dengan kondisi wilayah DAS Sumber Brantas terdiri dari dua sumber utama. Literatur tentang studi terkait dan penelitian dari berbagai instansi maupun pihak (perorangan) merupakan sumber pertama yang dipergunakan untuk melengkapi informasi tentang kondisi DAS Sumber Brantas. Informasi lainnya didapatkan dari tulisan maupun artikel-artikel yang berasal dari media website (internet). Kedua sumber literatur ini diharapkan dapat memperlengkap dokumendokumen yang berisi informasi yang diperlukan untuk memperkuat analisis dalam studi yang dilakukan. Beberapa dokumen yang dimaksud di atas antara lain disebutkan pada tabel di bawah ini.

Tabel 2.1. Dokumen dan laporan-laporan bahan studi

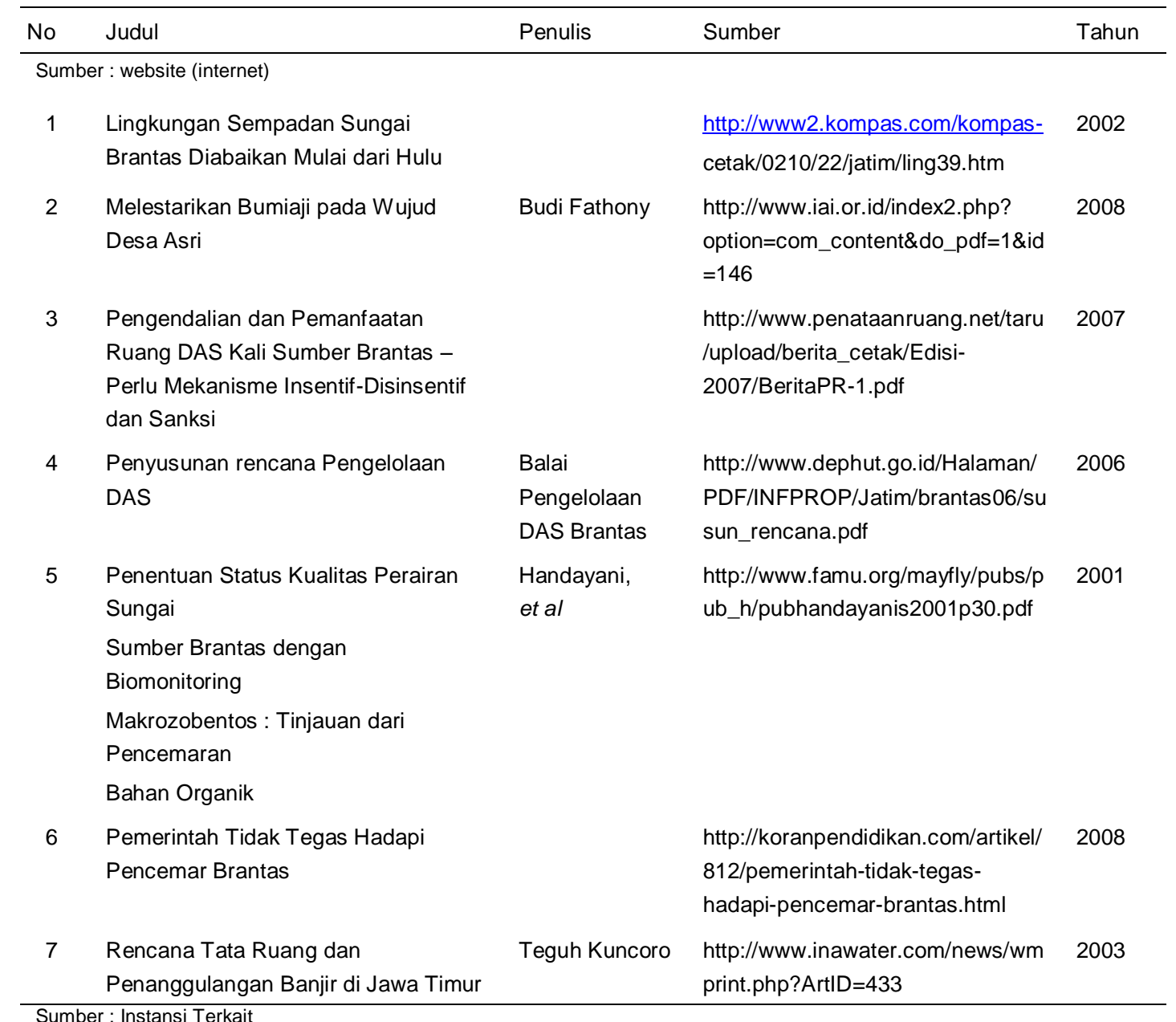




\begin{tabular}{|c|c|c|c|c|}
\hline No & Judul & Penulis & Sumber & Tahun \\
\hline 1 & $\begin{array}{l}\text { Penggunaan GenRiver (Generic } \\
\text { Model on River Flow) untuk Prediksi } \\
\text { Debit Sungai di DAS Brantas }\end{array}$ & Indah K & $\begin{array}{l}\text { Jurusan Tanah, Fakultas } \\
\text { Pertanian, UB }\end{array}$ & 2003 \\
\hline 2 & $\begin{array}{l}\text { Kajian Dampak Penebangan Hutan } \\
\text { terhadap Debit Air di DAS Brantas }\end{array}$ & $\begin{array}{l}\text { Ika Fida } \\
\text { Ernawati }\end{array}$ & $\begin{array}{l}\text { Jurusan Tanah, Fakultas } \\
\text { Pertanian, UB }\end{array}$ & 2003 \\
\hline 3 & $\begin{array}{l}\text { Kajian Kelestarian Sumber Air di Kota } \\
\text { Batu }\end{array}$ & & $\begin{array}{l}\text { Jurusan Tanah, Fakultas } \\
\text { Pertanian, UB }\end{array}$ & 2007 \\
\hline 4 & $\begin{array}{l}\text { Pemetaan Partisipatif-Penguasaan } \\
\text { Wengkon dan Sistem Pengelolaannya } \\
\text { untuk Mendukung Penyusunan } \\
\text { Rencana Strategi dan Operasional } \\
\text { LMDH Kota Batu }\end{array}$ & $\begin{array}{l}\text { Iva Dewi L, } \\
\text { Syahrul K, } \\
\text { Widianto }\end{array}$ & $\begin{array}{l}\text { ESP (Environmental Services } \\
\text { Program) Jawa Timur }\end{array}$ & 2006 \\
\hline 5 & $\begin{array}{l}\text { Laporan Sosial Ekonomi-Studi Detail } \\
\text { Konservasi Sub DAS Sumber Brantas }\end{array}$ & & $\begin{array}{l}\text { IPK-PWS Kali Brantas, DPU Dirjen } \\
\text { Sumberdaya Air }\end{array}$ & 2006 \\
\hline 6 & $\begin{array}{l}\text { Laporan Perencanaan Detail } \\
\text { Konservasi-Studi Detail Konservasi } \\
\text { Sub DAS Sumber Brantas }\end{array}$ & & $\begin{array}{l}\text { IPK-PWS Kali Brantas, DPU Dirjen } \\
\text { Sumberdaya Air }\end{array}$ & 2006 \\
\hline 7 & $\begin{array}{l}\text { Laporan Penyelidikan Tanah-Studi } \\
\text { Detail Konservasi Sub DAS Sumber } \\
\text { Brantas }\end{array}$ & & $\begin{array}{l}\text { IPK-PWS Kali Brantas, DPU Dirjen } \\
\text { Sumberdaya Air }\end{array}$ & 2006 \\
\hline 8 & $\begin{array}{l}\text { Rencana Aksi Pengelolaan Sub DAS } \\
\text { Sumber Brantas, Kota Batu, Jawa } \\
\text { Timur }\end{array}$ & & $\begin{array}{l}\text { Fokal Mesra (Forum Kajian Air } \\
\text { dan Lingkungan Menuju Selaras } \\
\text { Alam) }\end{array}$ & 2007 \\
\hline 9 & $\begin{array}{l}\text { Penilaian Kelas kesesuaian lahan } \\
\text { untuk pohon kayu putih (Eucalyptus } \\
\text { sp) dan kayu manis (Cinnamomum } \\
\text { burmanii) di arboretum, } \\
\text { Sumberbrantas Kodya Batu }\end{array}$ & Wibi Rikananto & $\begin{array}{l}\text { Jurusan Tanah, Fakultas } \\
\text { Pertanian, UB }\end{array}$ & 2005 \\
\hline 10 & $\begin{array}{l}\text { Penentuan tingkat kesesuaian lahan } \\
\text { tanaman apel, alpokad dan kopi } \\
\text { arabika di Sumberjo Batu }\end{array}$ & $\begin{array}{l}\text { Dwi Putra } \\
\text { Santosa }\end{array}$ & $\begin{array}{l}\text { Jurusan Tanah, Fakultas } \\
\text { Pertanian, UB }\end{array}$ & 2005 \\
\hline 11 & $\begin{array}{l}\text { Pengaruh sifat fisik tanah terhadap } \\
\text { jumlah pencucian nitrat di kawasan } \\
\text { arboretum Sumberbrantas }\end{array}$ & $\begin{array}{l}\text { Lovina Rahayu } \\
\text { Ratnawati }\end{array}$ & $\begin{array}{l}\text { Jurusan Tanah, Fakultas } \\
\text { Pertanian, UB }\end{array}$ & 2005 \\
\hline 12 & $\begin{array}{l}\text { Agretasi tanah pada berbagai } \\
\text { penggunaan lahan di Sumberbrantas }\end{array}$ & $\begin{array}{l}\text { Rhomadona } \\
\text { Herlis } \\
\text { Oktaviano }\end{array}$ & $\begin{array}{l}\text { Jurusan Tanah, Fakultas } \\
\text { Pertanian, UB }\end{array}$ & 2008 \\
\hline 13 & $\begin{array}{l}\text { Kajian bahaya longsor tebing jalan di } \\
\text { sub DAS Bango }\end{array}$ & Bayu Widarto & $\begin{array}{l}\text { Jurusan Tanah, Fakultas } \\
\text { Pertanian, UB }\end{array}$ & 2006 \\
\hline 14 & $\begin{array}{l}\text { Kajian penyebab terjadinya tanah } \\
\text { longsor tebing jalan di daerah aliran } \\
\text { sungai (DAS) Sumber Brantas Kota } \\
\text { Batu }\end{array}$ & Yahya Luthfi & $\begin{array}{l}\text { Jurusan Tanah, Fakultas } \\
\text { Pertanian, UB }\end{array}$ & 2006 \\
\hline 15 & $\begin{array}{l}\text { Perubahan sifat fisiko-kimia tanah } \\
\text { pada berbagai posisi lereng di } \\
\text { toposekuen Gunung Pucung Desa } \\
\text { Bulukerto Kecamatan Bumiaji }\end{array}$ & Sri WAhyuni & $\begin{array}{l}\text { Jurusan Tanah, Fakultas } \\
\text { Pertanian, UB }\end{array}$ & 2006 \\
\hline 16 & $\begin{array}{l}\text { Pengaruh sifat geomorfologi lahan dan } \\
\text { vegetasi terhadap longsor tebing } \\
\text { sungai bentuk V di Sub DAS Bango }\end{array}$ & Arie Wardani & $\begin{array}{l}\text { Jurusan Tanah, Fakultas } \\
\text { Pertanian, UB }\end{array}$ & 2006 \\
\hline
\end{tabular}




\begin{tabular}{|c|c|c|c|c|}
\hline No & Judul & Penulis & Sumber & Tahun \\
\hline 17 & $\begin{array}{l}\text { Pengaruh lereng tebing dan } \\
\text { penggunaan lahan di sempadan } \\
\text { sungai sub DAS Bango terhadap } \\
\text { longsor }\end{array}$ & $\begin{array}{l}\text { Whina Vinolia } \\
\text { Hayuningtias }\end{array}$ & $\begin{array}{l}\text { Jurusan Tanah, Fakultas } \\
\text { Pertanian, UB }\end{array}$ & 2006 \\
\hline 18 & $\begin{array}{l}\text { Hubungan ketinggian muka air tanah } \\
\text { dengan morfologi tanah di Arboretum, } \\
\text { Sumber Brantas, Kota Batu }\end{array}$ & $\begin{array}{l}\text { Nuryastuti } \\
\text { Dewi }\end{array}$ & $\begin{array}{l}\text { Jurusan Tanah, Fakultas } \\
\text { Pertanian, UB }\end{array}$ & 2006 \\
\hline 19 & $\begin{array}{l}\text { Kajian longsor di DAS Sumber } \\
\text { Brantas : Pendugaan biomassa } \\
\text { tanaman dan penutupan lahan } \\
\text { menggunakan NDVI (Natural Different } \\
\text { Vegetation Index) }\end{array}$ & Rendy Martino & $\begin{array}{l}\text { Jurusan Tanah, Fakultas } \\
\text { Pertanian, UB }\end{array}$ & 2007 \\
\hline 20 & $\begin{array}{l}\text { Kajian kekeringan lahan di DAS } \\
\text { Sumber Brantas : Validasi indeks } \\
\text { kekeringan palmer dengan } \\
\text { menggunakan penginderaan jauh dan } \\
\text { sistem informasi }\end{array}$ & $\begin{array}{l}\text { Erwin } \\
\text { Elyatalatof }\end{array}$ & $\begin{array}{l}\text { Jurusan Tanah, Fakultas } \\
\text { Pertanian, UB }\end{array}$ & 2007 \\
\hline 21 & $\begin{array}{l}\text { Studi perkembangan dan klarifikasi } \\
\text { tanah pada lereng selatan Gunung } \\
\text { Pucung Kecamatan Bumiaji Kodya } \\
\text { Batu }\end{array}$ & Fahmi Habib & $\begin{array}{l}\text { Jurusan Tanah, Fakultas } \\
\text { Pertanian, UB }\end{array}$ & 2008 \\
\hline
\end{tabular}

\subsection{Analisa Spasial}

\subsubsection{Lokasi Studi}

DAS Sumber Brantas terletak di Provinsi Jawa Timur, dengan luas sekitar 17.344ha. Wilayah DAS ini sebagian besar berada di wilayah Kota Batu dan sebagian kecil berada di Kabupaten Malang (Kecamatan Pujon dan Karangploso). Bagian hulu termasuk kawasan Taman Hutan

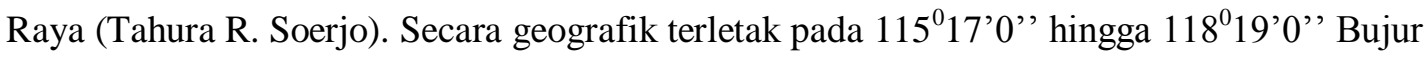
Timur dan 7055'30', hingga 7057'30', Lintang Selatan. Letak DAS Sumber Brantas di wilayah Malang Raya (Kabupaten Malang, Kota Malang dan Kota Batu) disajikan pada gambar 2.1.

Berbagai peta digital dikumpulkan dan/atau didigitasi dari peta analog. Peta digital diturunkan dari peta Rupa Bumi Indonesia (RBI) skala 1:25,000 dalam format AutoCad. Peta RBI menurunkan beberapa peta antara lain:

- Jalan

- Sungai

- Batas administrasi dan

- Kontur

Sementara itu, peta yang dihasilkan dari proses digitasi antara lain adalah:

- Peta Geologi, skala 1:100,000 dan

- Peta Satuan Lahan (bentuk lahan) dan Peta Tanah (skala 1:50,000) 


\subsubsection{Komponen Data Geospasial}

Data spasial pada umumnya mempunyai berbagai macam format dan parameter geografi. Dalam meng-overlay-kan antara satu peta dan peta lainnya, format dan parameter yang berbeda-beda tersebut haruslah disamakan terlebih dahulu. Hal-hal yang perlu diperhatikan dari peta-peta yang akan di-overlay antara lain adalah:

- Proyeksi

- Sistem Koordinat (Coordinate system)

- Ellipsoid dan/ atau Datum

1. Proyeksi

Proyeksi dalam suatu peta merupakan upaya untuk melukiskan permukaan bumi dalam bentuk bidang atau permukaan yang datar. Beberapa distorsi jarak, arah, skala dan area selalu dihasilkan dalam proses ini. Proyeksi terkadang mengurangi distorsi, namun menambah eror pada bagian yang lainnya.

2. Sistem Koordinat

Sistem koordinat digunakan untuk menandai posisi muka bumi pada peta yang dibuat. Terdapat berbagai macam sistem koordinat yang dipergunakan pada saat ini antara lain sistem koordinat yang dibuat berdasarkan keragaman datum, unit, proyeksi dan sistem referensi. Dua macam sistem koordinat yang biasa digunakan dalam pembuatan peta di Indonesia adalah sistem latitude-longitude (derajad) dan sistem UTM (metric).

3. Ellipsoid \& Geodetic Datum

Dua parameter geodesi (elipsoid dan datum) menentukan koordinat dalam dua sistem proyeksi yang digunakan. Model elipsoid membatasi sistem referensi yang mendiskripsikan ukuran dan bentuk dari permukaan bumi. Dengan kata lain, dua parameter ini menggambarkan permukaan bumi dalam wilayah tertentu dan digunakan sebagai parameter dalam proses proyeksi.

Semua data spasial yang diperoleh dari berbagai sumber yang dipergunakan dalam studi ini mempunyai proyeksi dan elipsoid (datum) yang berbeda. Namun demikian, dalam studi ini sistem koordinat yang dipergunakan adalah sistem proyeksi UTM dan datum WGS84.

\subsubsection{Digital Elevation Models (DEM) dan Atribut Turunannya}

Sebuah peta DEM diperlukan untuk menghasilkan informasi-informasi tentang kondisi topografi dan atribut-atribut hidrologi. DEM yang dibuat berupa format raster dengan resolusi $15 \mathrm{~m}$. Bahan yang digunakan untuk membuat DEM ini adalah kontur pada Peta Rupa Bumi Indonesia (RBI). 
Peta Rupa Bumi diperoleh dari Bakosurtanal Bogor. DAS Sumber Brantas terliput oleh enam lembar Peta RBI, yaitu: Lembar Panglungan, Lembar Trawas, Lembar Pujon, Lembar Bumiaji, Lembar Banjarrejo dan Lembar Batu.

Kontur yang terdapat pada RBI tersebut masih terdapat kesalahan elevasi, sehingga harus dilakukan editing elevasi pada beberapa kontur yang tidak benar.

\section{Acquisition and processing}

Lembar peta RBI yang digunakan dalam kegiatan ini ada enam lembar (sheet), yaitu: Lembar Panglungan, Trawas, Pujon, Bumiaji, Sumberrejo dan Batu seperti yang disajikan dalam Gambar 2.1.

Garis kontur dari RBI seringkali mengandung kesalahan informasi ketinggian garis kontur. Oleh karena itu, perlu melihat kesalahan tersebut dengan membuat TIN. Salah satu contoh ketinggian yang salah dan hasil revisinya seperti yang disajikan pada Gambar 2.2. Perbaikan dilakukan pada kontur yang menghasilkan elevasi yang salah. Setelah perbaikan elevasi, layer kontur pada masing-masing lembar digabung (merge) menjadi satu layer, hasilnya seperti yang disajikan pada Gambar 2.3. 


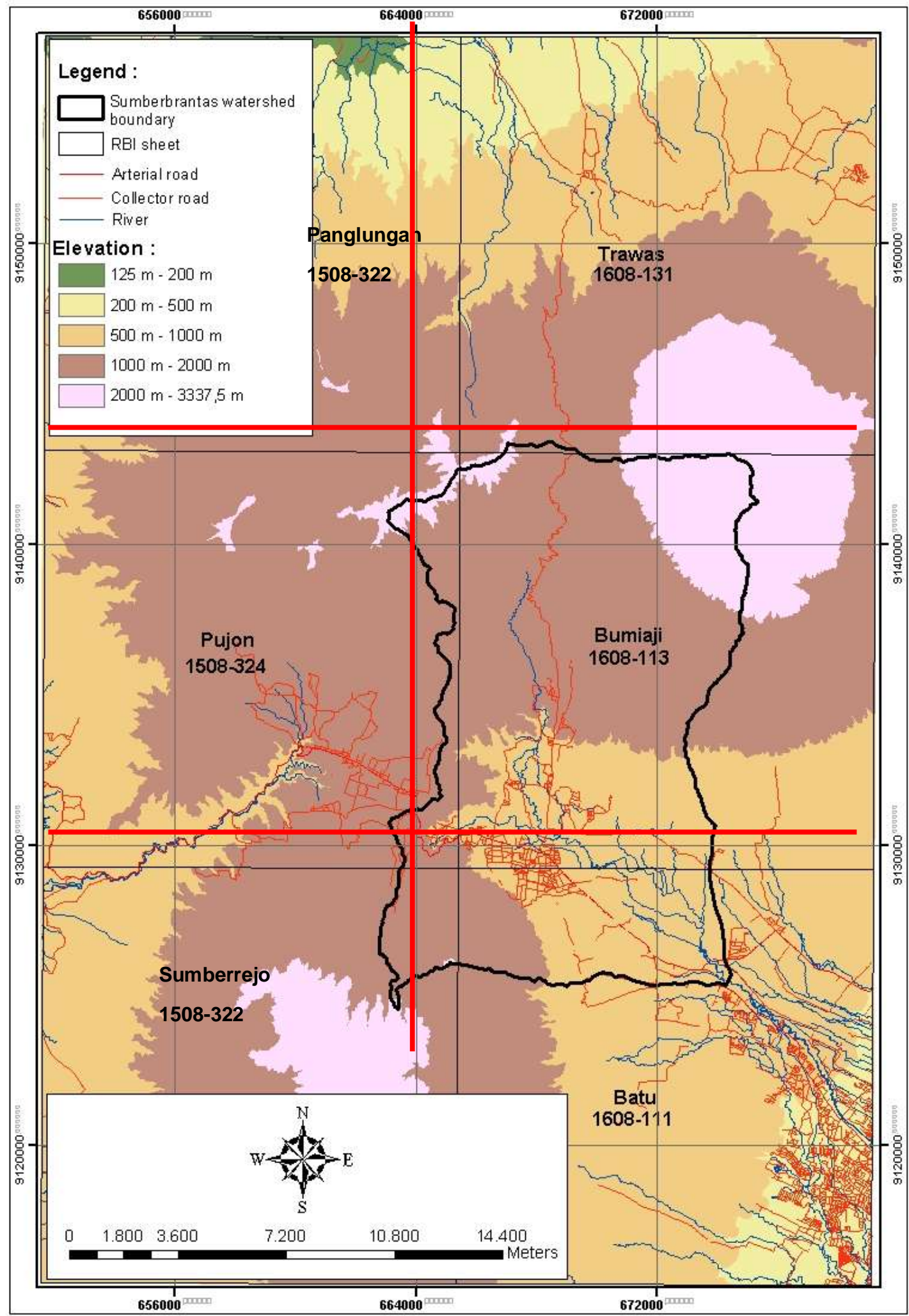

Gambar 2.1. Potongan peta RBI yang meliputi wilayah DAS Sumber Brantas 

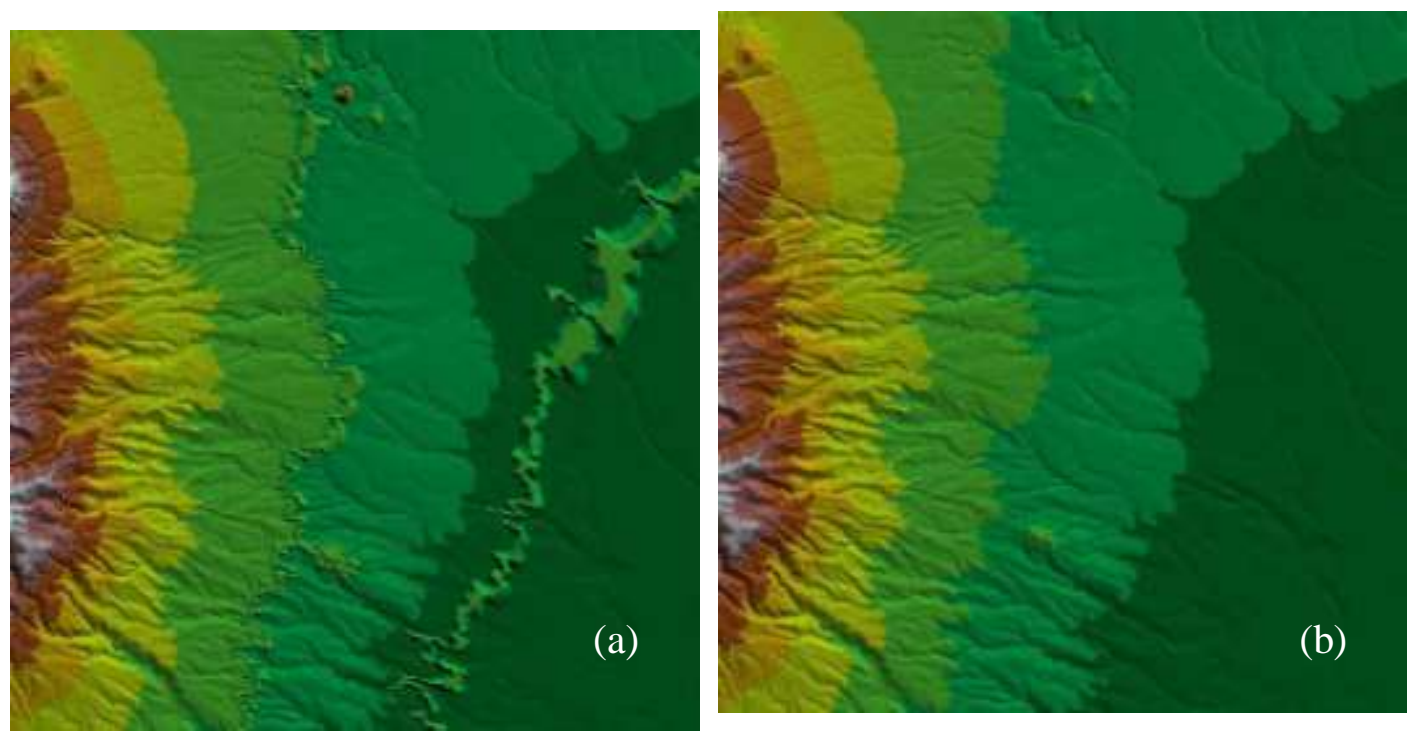

Gambar 2.2. (a) TIN Peta RBI lembar Batu dengan kesalahan ketinggian garis kontur, dan (b) TIN setelah kesalahan ketinggian pada kontur diperbaiki

\section{Batas Catchment dan SubCatchment}

Dari peta DEM yang ada akan diperoleh slope (deskripsi landform), saluran drainase (stream), batas-batas subcatchment dan routing distance. Selanjutnya, batas subcatchment serta routing distance merupakan input yang akan dipergunakan dalam model GenRiver. Metode atau alur kerja yang dipergunakan untuk menentukan batas subcatchment serta routing distance disajikan pada gambar berikut.

Batas catchment diketahui melalui penelurusan arah aliran dari outlet yang telah diketahui. Sementara itu, batas micro catchment dalam suatu catchment ditentukan dengan mengunakan nilai batas (threshold value). Penggabungan beberapa micro catchment pada akhirnya akan menghasilkan batas subcatchment. Pengujian terhadap batas-batas catchment dan subcatchment yang telah dibuat dilakukan baik secara spasial (dengan menggunakan skala yang lebih halus) maupun dilakukan dengan pengecekan langsung di lapang. 


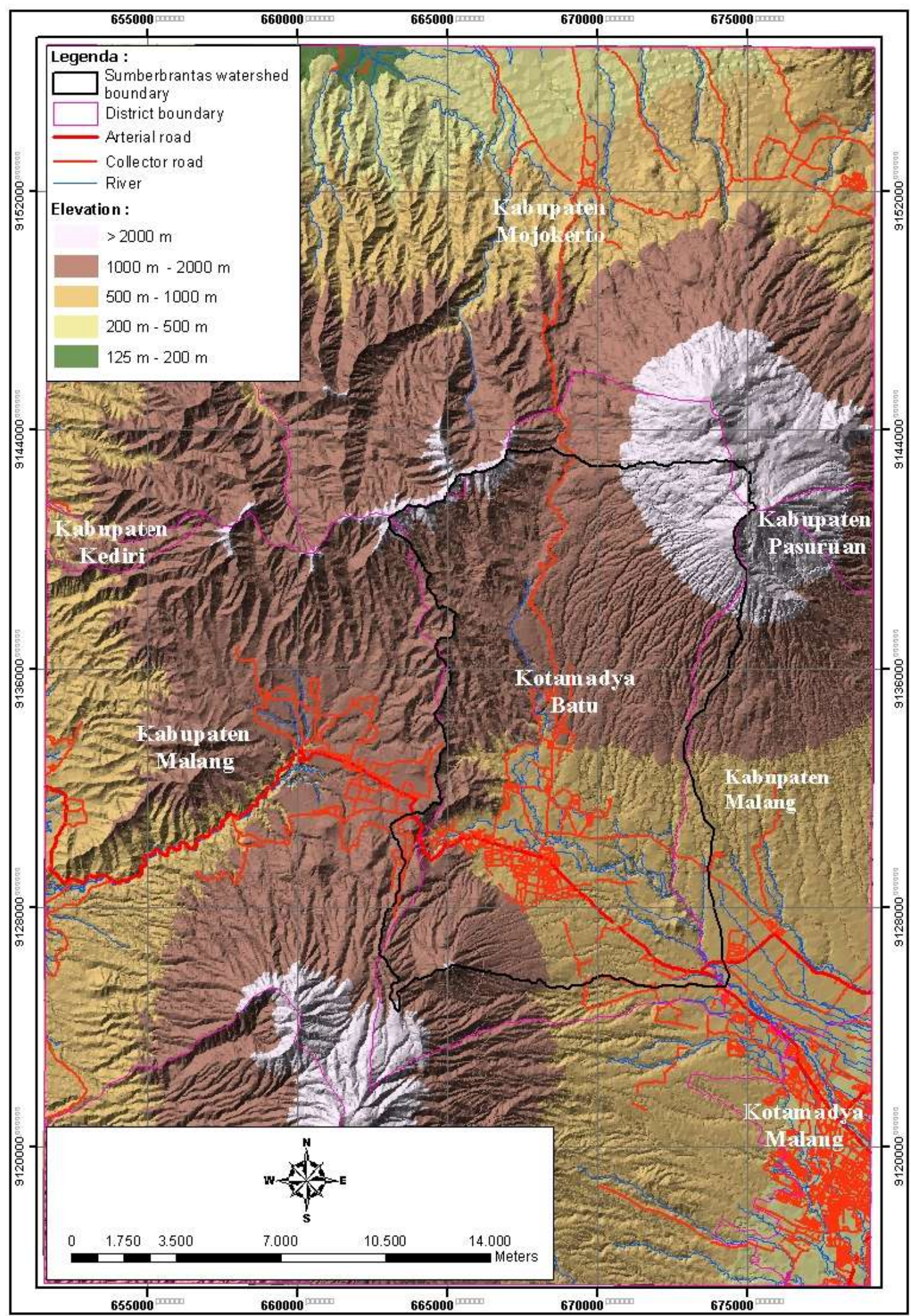

Gambar 2.3. Peta Digital Elevation Model DAS Sumber Brantas yang diperoleh dari peta RBI 


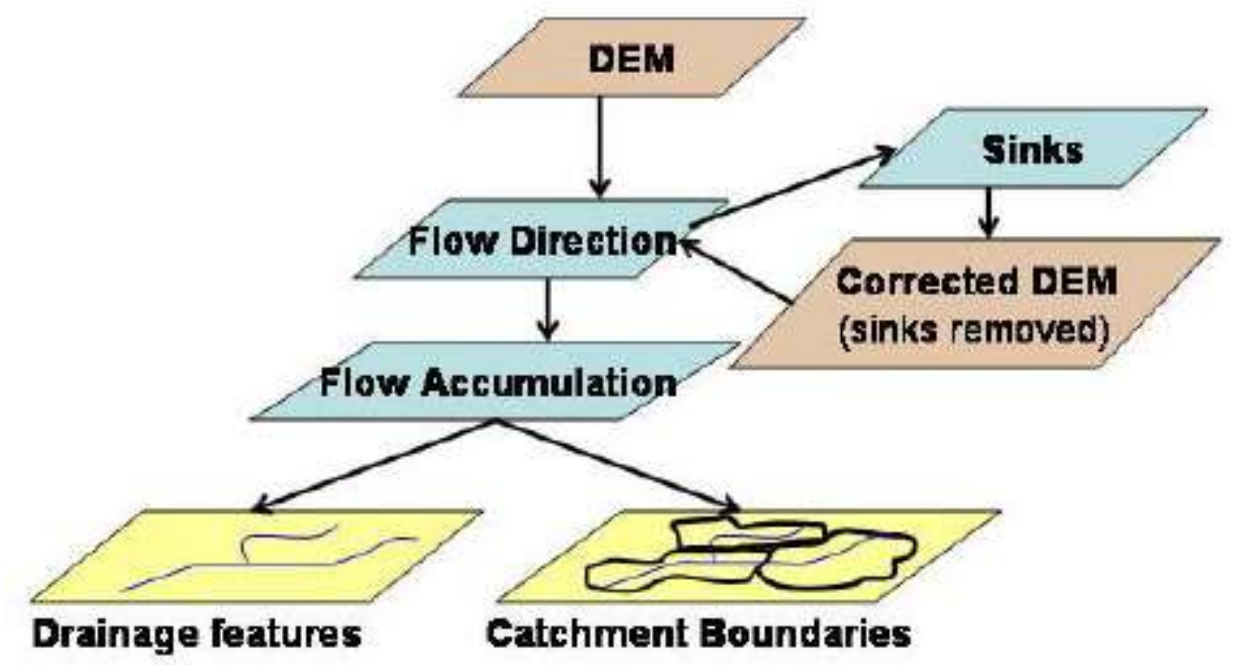

Gambar 2.4. Alur kerja dalam penentuan batas subcathcment dan saluran drainase dalam DAS

\section{Penentuan Routing Distance}

Dalam model GenRiver ada dua macam routing distance yang dijadikan sebagai input untuk model ini. Pertama adalah routing distance to the lake (routing distance ke arah outlet). Kedua adalah routing distance yang ditarik dari titik observasi yang telah ditentukan. Penentuan titik awal dari suatu routing distance pada setiap subcatchment dilakukan dengan menetapkan terlebih dahulu titik tengah (centroid) dari subcatchment. Setelah itu, routing distance dihitung melalui pengukuran panjang sungai dari bagian sungai yang terdekat dengan titik tengah subcatchment ke arah outlet yang telah ditentukan.

\subsubsection{Metode Klasifikasi Penutupan Lahan}

Metode atau alur kerja yang dipergunakan dalam klasifikasi penutupan lahan disajikan pada gambar 2.5. Langkah pertama yang dilakukan adalah pemotongan Citra (Image) Landsat sesuai dengan ukuran yang dikehendaki. Setelah itu, baru dilakukan koreksi geometrik. 


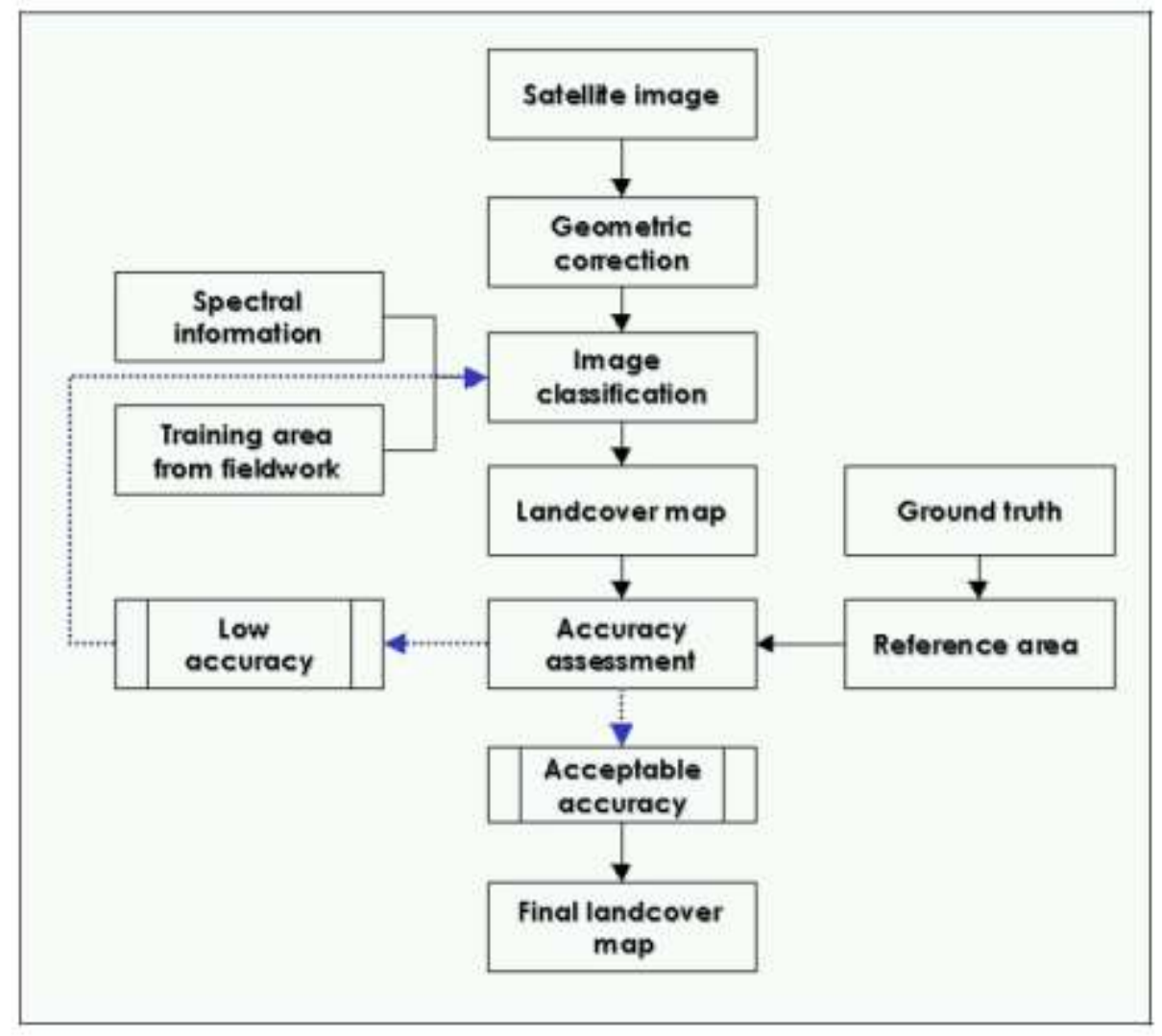

Gambar 2.5. Alur kerja dalam proses klasifikasi penutupan lahan

\section{Acquisition and Processing}

Informasi tentang kondisi penutupan lahan di DAS Sumber Brantas diperoleh dari image Landsat ETM yang telah terkoreksi secara geometrik. Penutupan lahan yang dimaksud adalah tanaman atau bentukan-bentukan lahan lainnya (buatan manusia) yang secara nyata menjadi penutup permukaan lahan. Penentuan jenis landcover penting sebagai input data untuk model GenRiver dalam metode RHA. Jenis landcover dalam hal ini dapat menghasilkan parameter yang berpengaruh terhadap kondisi hidrologi DAS. Parameter-parameter tersebut adalah infiltrasi dan evapotranspirasi.

Citra landsat ETM (Enhanced Thematic Mapper) yang diperoleh dari Bidang Penyajian Data Pusat Data Pengindraan Jauh LAPAN dan Tropical Rain Forest Information Centre (TRFIC) (http://brsi.msu.edu/trfic) digunakan dalam studi ini untuk memperoleh peta penutupan lahan di wilayah DAS Sumber Brantas. Table Deskripsi tentang spesifikasi citra landsat tersebut disajikan pada tabel 2.2. Sementara itu, Citra Landsat ETM 7 tahun 2002 disajikan pada Gambar 2.6. 


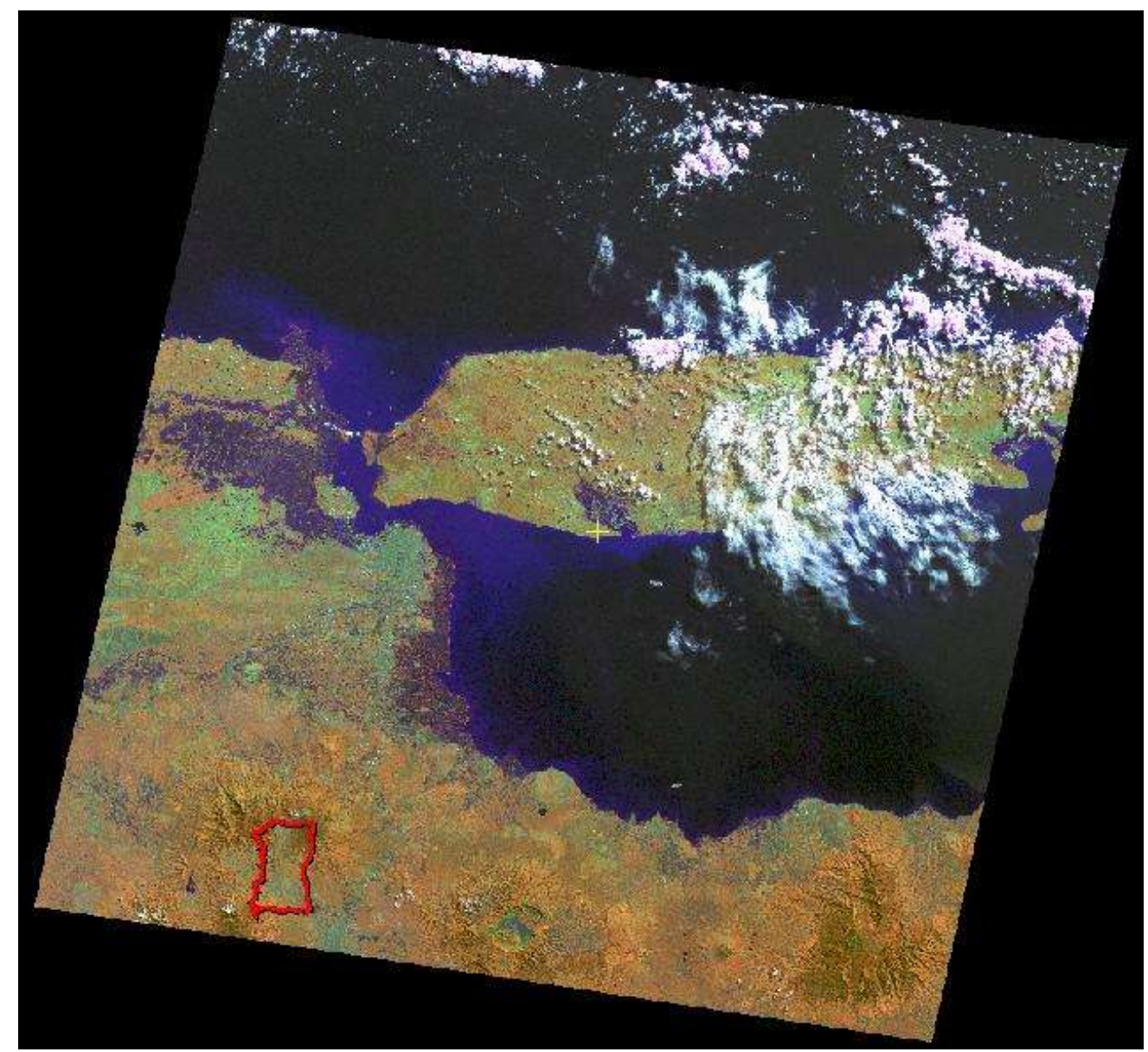

Gambar 2.6. Citra Landsat ETM 7 P116 R 065 tahun 2002

Table 2.2. Spesifikasi Citra Landsat ETM

\begin{tabular}{lcc}
\hline Specifications & P118 R065 & P118 R065 \\
\hline Acquisition date & August, 28 & February, 18th 1989 \\
Number of channels & 8 & 8 \\
Sun azimuth & 53,97 & $*$ \\
Sun elevation & 52,43 & $*$ \\
Cloud cover & $0,34 \%$ & $4,10 \%$ \\
\hline
\end{tabular}

Note: $P=$ path $R=$ row

\section{Koreksi Geometrik}

Koresi geometrik dilakukan dengan pembetulan citra satelit melalui penentuan titik acuan (ground control point $=$ GCP) pada sebuah sistem koordinat. GCP diletakkan pada lokasi-lokasi yang mudah dikenali seperti perempatan jalan, jembatan atau percabangan sungai. Pengukuran manual terhadap posisi lokasi-lokasi yang dimaksud dilakukan dari peta topografi karena peta topografi tersebut hanya tersedia dalam bentuk hard copy. Pengukuran manual seperti ini 
mempunyai nilai error sebesar $0.5 \mathrm{~mm}$. Ketepatan dari hasil pengukuran akan menunjukkan kemungkinan kesalahan terkecil yang diharapkan setelah dilakukan proses koreksi geometrik. Dalam hal ini, ketepatan $0.5 \mathrm{~mm}$ pada peta topografi dengan skala $1: 25,000$ berarti $12.5 \mathrm{~m}$ atau sekitar 2 piksel dari Citra Landsat ETM dengan resolusi 30m.

Tabel 2.3 menunjukkan total jumlah dari titik kontrol yang digunakan dalam proses koreksi geometrik, nilai rata-rata root mean square error (RMSE) dan nilai maksimum dan minimum residual erros dari semua titik acuan (GCP). Rata-rata nilai RMSE menunjukkan bahwa peluang dari semua distorsi dari image yang terkoreksi adalah sekitar 50m pada seluruh arah. Nilai RMSE ini juga digunakan dalam proses akurasi planimetrik dari citra satelit dan produk-produk turunannya. Hasil koreksi geometri bagi citra Landsat P118 R065 tahun 2002 disajikan pada Gambar 2.7.

Table 2.3. Hasil koreksi geometrik

\begin{tabular}{llcc}
\hline No & Factors & Landsat 118/065 (2002) & Landsat 118/065 (1989) \\
\hline 1 & Number of GCP & 8 & 8 \\
2 & RMSE on x-axis ( m ) & 18.75 & 27.82 \\
3 & RMSE on y-axis ( m ) & 49.53 & 45.45 \\
4 & Average RMSE (m) & 52.96 & 53.29 \\
\hline
\end{tabular}




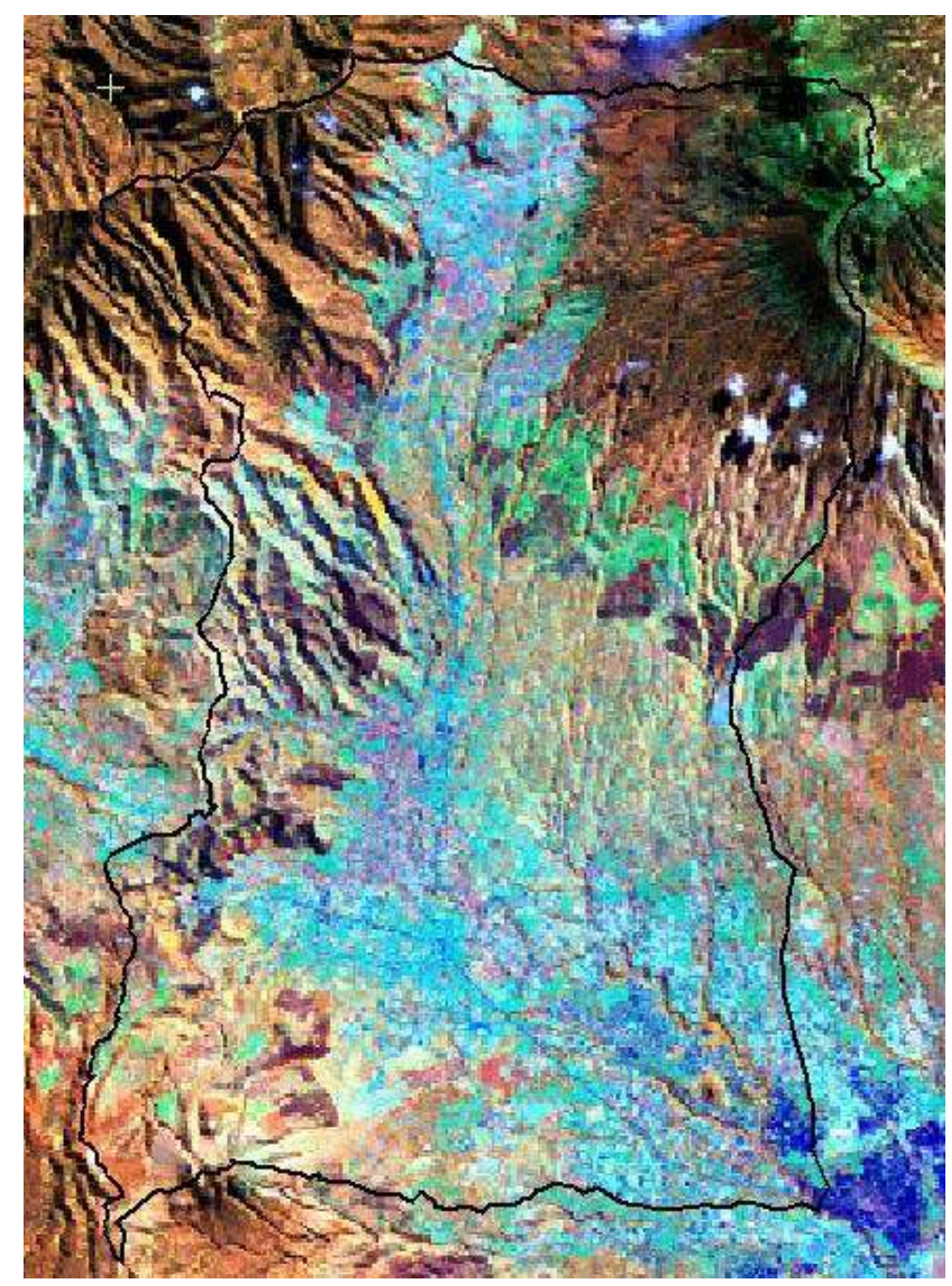

Gambar 2.7. Citra Landsat ETM 7 tahun 2002

\section{Survei Lapang Penentuan Jenis Penutupan Lahan}

Survei lapang dilakukan pada bulan Oktober 2008. Pada survei ini diperoleh banyak informasi tentang kondisi eksisting lahan serta jenis penutupan lahan di lokasi studi. Informasi yang didapatkan dipergunakan sebagai dasar penentuan tipe dan karakteristik penutupan lahan di DAS Sumber Brantas. Terdapat 8 jenis penutupan lahan utama yang digunakan dalam proses pengklasifikasian landcover di DAS Sumber Brantas, antara lain:

\section{a. Hutan}

Hutan didefinisikan sebagai suatu wilayah yang dicirikan dengan luasnya pohon-pohon alami. Pohon-pohon dalam hutan bervariasi dalam hal spesies, distribusi diameter, total basar area pada tiap kelas umur. Klasifikasi hutan di DAS Sumber Brantas terdiri dari hutan primer (natural forest) dan hutan sekunder (hutan terganggu). 
b. Agroforestry berbasis pohon

Ada dua macam agroforestry berbasis pohon di wilayah studi, yaitu: hutan pinus dan kebun campuran (mixed garden) di kawasan budidaya. Hutan pinus merupakan hutan tanaman industri dengan jenis tanaman yang monokultur. Kebun campuran (mixed garden) merupakan campuran tanaman kayu-kayuan (dan bambu) dengan tanaman buah-buahan seperti alpukat, nangka, klengkeng, dll.

c. Kebun

Kebun yang dijumpai di DAS Sumber Brantas adalah kebun apel, jeruk dan aneka bunga.

d. Lahan Pertanian

Lahan pertanian dalam hal ini adalah lahan-lahan yang ditanami tanaman hortikultura seperti sayuran. Tanaman sayuran ini merupakan jenis penutupan lahan yang sangat intesif dikelola di DAS Sumber Brantas.

\section{e. Rice field}

Lahan sawah didefinisikan sebagai suatu lahan yang ditanami oleh tanaman padi, baik itu padi di lahan irigasi maupun dari padi yang ditanam di dataran tinggi. Pada umumnya lahan sawah berada di sekitar pemukiman, dataran aluvial (dekat sungai).

\section{f. Semak}

Semak dicirikan dengan adanya tanaman rumput yang tumbuh bersama-sama dengan tanaman semak (kayu-kayuan). Semak di wilayah DAS Sumber Brantas pada umumnya adalah lahan bekas hutan yang ditebang kayunya. Biasanya terletak pada kelerengan yang cukup curam untuk dapat dikelola oleh masyarakat sekitar.

g. Wilayah Pemukiman

Pemukiman merupakan wilayah yang dipergunakan oleh manusia sebagai tempat tinggalnya. Wilayah pemukiman termasuk dalam hal ini wilayah pedesaan dan jalan-jalan utama.

\section{Object-based Classification}

Klasifikasi berdasarkan obyek (object-based classification) merupakan suatu pendekatan baru dalam metode pengklasifikasian citra. Dalam metode ini, dipergunakan image objects sebagai pengganti dari piksel tunggal. Image object merupakan unit utama dalam observasi yang dipergunakan dalam proses klasifikasi. Image object lebih jauh adalah satu set piksel yang homogen yang diasumsikan dapat merepresentasikan suatu obyek aktual yang ada di permukaan bumi. Piksel-piksel yang homogen tersebut diidentifikasi melalui proses segementasi image 
dengan mempertimbangkan bentuk, skala, dan warna (kesamaan spektrum). Ada dua langkah dalam proses ini yaitu metode segmentasi dan klasifikasi penutupan lahan secara hierarki, yaitu:

\section{a. Segmentasi}

Segmentasi dilakukan berkali-kali agar menghasilkan image object dengan skala yang berbeda sehingga menggambarkan ukuran yang berbeda tentang suatu obyek di permukaan bumi. Sebagai contoh, skala yang lebih halus akan diperlukan untuk mengklasifikasikan jalan dan sungai. Namun demikian, skala tersebut tidak akan diperlukan untuk mengklasifikasikan obyek lain yang lebih besar seperti lahan pertanian atau hutan. Dalam hal ini, proses segmentasi sebagian besar ditentukan oleh pengamatan visual, atau jika tersedia akan peta dengan resolusi yang sangat tinggi akan sangat membantu proses segementasi ini. Hasil dari proses segmentasi adalah sebuah sebuah struktur yang disebut sebagai multiresolution image objects.

\section{b. Hierarki Klasifikasi Penutupan Lahan}

Struktur hierarki dipergunakan untuk menandai suatu obyek dalam suatu kelas pengklasifikasian. Masing-masing level mempunyai jenis spektrum dan informasi spasial yang berbeda, ukuran obyek, dan karakteristik masing-masing landcover. Hierarki dalam hal ini berperan dalam mengorganisir informasi yang sangat banyak yang ada dalam citra satelit.

Gambar 2.8 menunjukkan struktur hierarki klasifikasi penutupan lahan di DAS Sumber Brantas.

Gambar 2.8. Hierarki Klasifikasi Landuse di DAS Sumber Brantas

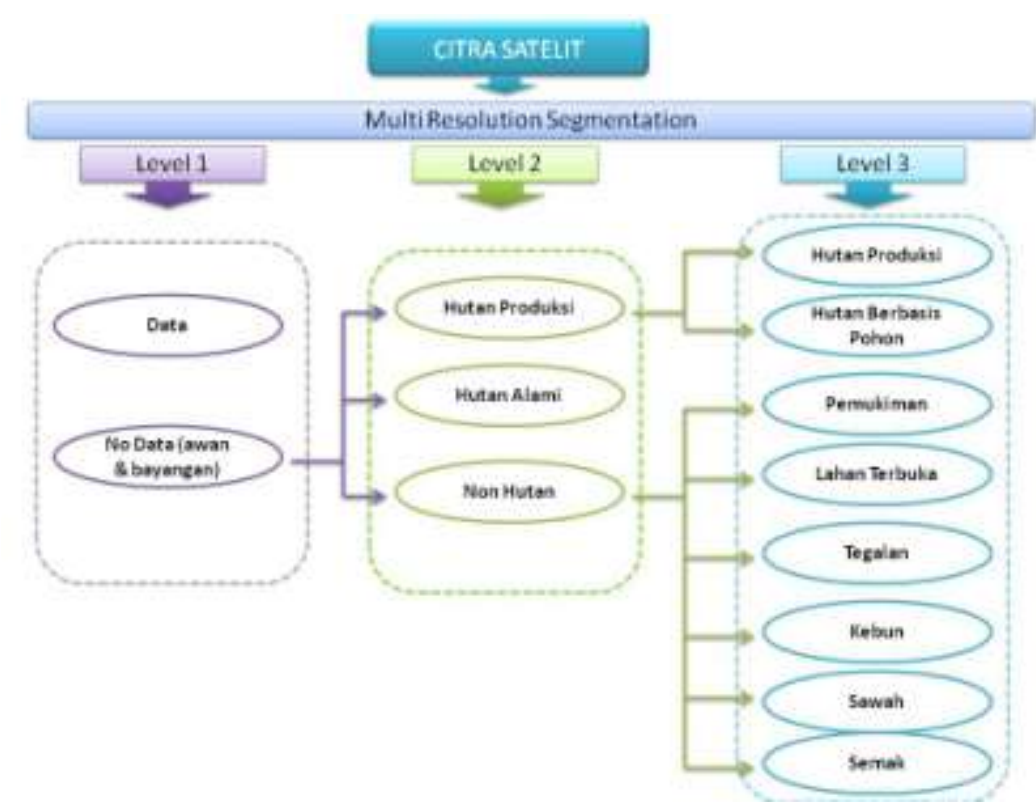

c. Land Cover information extraction

Image yang telah diklasifikasi di rubah dalam bentuk atau format vektor dan digabung dengan informasi spasial lainnya agar dapat menghasilkan informasi yang diperlukan oleh model GenRiver misalnya atau proporsi penutupan lahan di DAS Sumber Brantas di setiap 
subcatchment. Overlaying antara peta batas wilayah (misalnya subcatchment) dengan peta penutupan lahan dapat dipergunakan untuk mengetahui proporsi penutupan landcover di tiaptiap wilayah yang dikehendaki.

\subsection{Gambaran Umum Lokasi Studi}

\subsubsection{Kondisi landscape dan iklim, geologi DAS Sumber Brantas}

\section{Kondisi Landscape}

DAS Sumber Brantas terletak di bagian tengah Provinsi Jawa Timur, dengan luas sekitar 17,343.77ha. Wilayah DAS ini sebagian besar berada di Kota Madya Batu dan sebagian kecil berada di Kabupaten Malang (Kecamatan Pujon dan Karangploso). Bagian hulu termasuk kawasan Taman Hutan Raya (Tahura Suryo). Secara geografik terletak pada 115017'0' hingga 118019'0', Bujur Timur dan 7055'30', hingga 7057'30', Lintang Selatan.

DAS Sumber Brantas ini berada di wilayah pegunungan vulkanik yang mengelilinginya, yaitu: Gunung Arjuna-Welirang, Gunung Anjasmara dan Gunung Kawi-Butak. Gambaran relief dan kompleks pegunungan yang membatasi DAS Sumber Brantas telah disajikan pada pada Gambar 2.3 .

\section{Kondisi Iklim}

Secara kuantitas, nilai curah hujan tahunan rerata di sekitar DAS Sumber Brantas dan sekitarnya sesuai yang tercatat pada stasiun penakar adalah relatif besar. Sepanjang periode 30 tahun terakhir (1975 - 2004), curah hujan rerata tahunan pada daerah studi sebesar 1,876.70mm dengan nilai terkecil sebesar 1,009.9mm yang terjadi pada tahun 2004 dan terbesar sebesar 3,060.7mm yang terjadi pada tahun 1992. Bulan kering biasa terjadi pada bulan Mei sampai dengan Oktober, sedangkan bulan basah biasa terjadi antara awal bulan November sampai dengan April. Curah hujan rerata bulanan terbesar adalah $398.98 \mathrm{~mm}$ pada bulan Januari dan terkecil sebesar $10.98 \mathrm{~mm}$ pada bulan Agustus.

Dari hasil pencatatan pada Stasiun Tlekung selama 5 (lima) tahun terakhir (1996 - 2000), diperoleh nilai suhu udara rerata bulanan minimum sebesar $22.80^{\circ} \mathrm{C}$ yang terjadi pada bulan Januari dan maksimum sebesar $25.12^{\circ} \mathrm{C}$ yang terjadi pada bulan Mei. Kelembaban udara relatif tahunan rata-rata sebesar $85.33 \%$. Kelembapan udara maksimum sebesar $88.60 \%$ terjadi pada bulan April dan minimum sebesar $81.20 \%$ yang terjadi pada bulan Februari. 


\section{Kondisi Geologi}

Informasi Geologi diperoleh dari Peta Geologi skala 1:100,000 Lembar Malang (Santosa et.al., 1992). Secara umum tanah yang berkembang di DAS Sumber Brantas berkembang dari bahan vulkanik hasil gunung api, yang dipengaruhi oleh Gunung Arjuno dan Anjasmoro di bagian utara, dan Gunung Panderman di bagian selatan.

Berdasarkan Peta Geologi Lembar Malang (Santosa et.al., 1992), formasi geologi yang dijumpai di kawasan Kota DAS Sumber Brantas ada lima, berturut-turut dari yang paling luas yaitu: 1) Qvaw (Batuan Gunungapi Arjuna Welirang), 2) Qpat (Batuan Gunungapi Anjasmara Tua), 3) Qvp (Batuan Gunungapi Panderman), 4) Qpvkb (Batuan Gunungapi Kawi-Butak) dan 5) Qpva (Batuan Gunungapi Anjasmara Muda). Sebaran masing-masing formasi disajikan pada Gambar 2.9. Ditinjau dari umur batuan, Kompleks Pegunungan Anjasmara-Lalijiwa adalah pegunungan tua yang telah mati dan mengalami perusakan bentuk kerucut Gunung api. Kompleks pegunungan yang aling muda adalah Arjuna-Welirang, dimana Gunung Arjuna sedang istirahat dan Gunung Welirang masih aktif dengan mengeluarkan gas (belerang). 


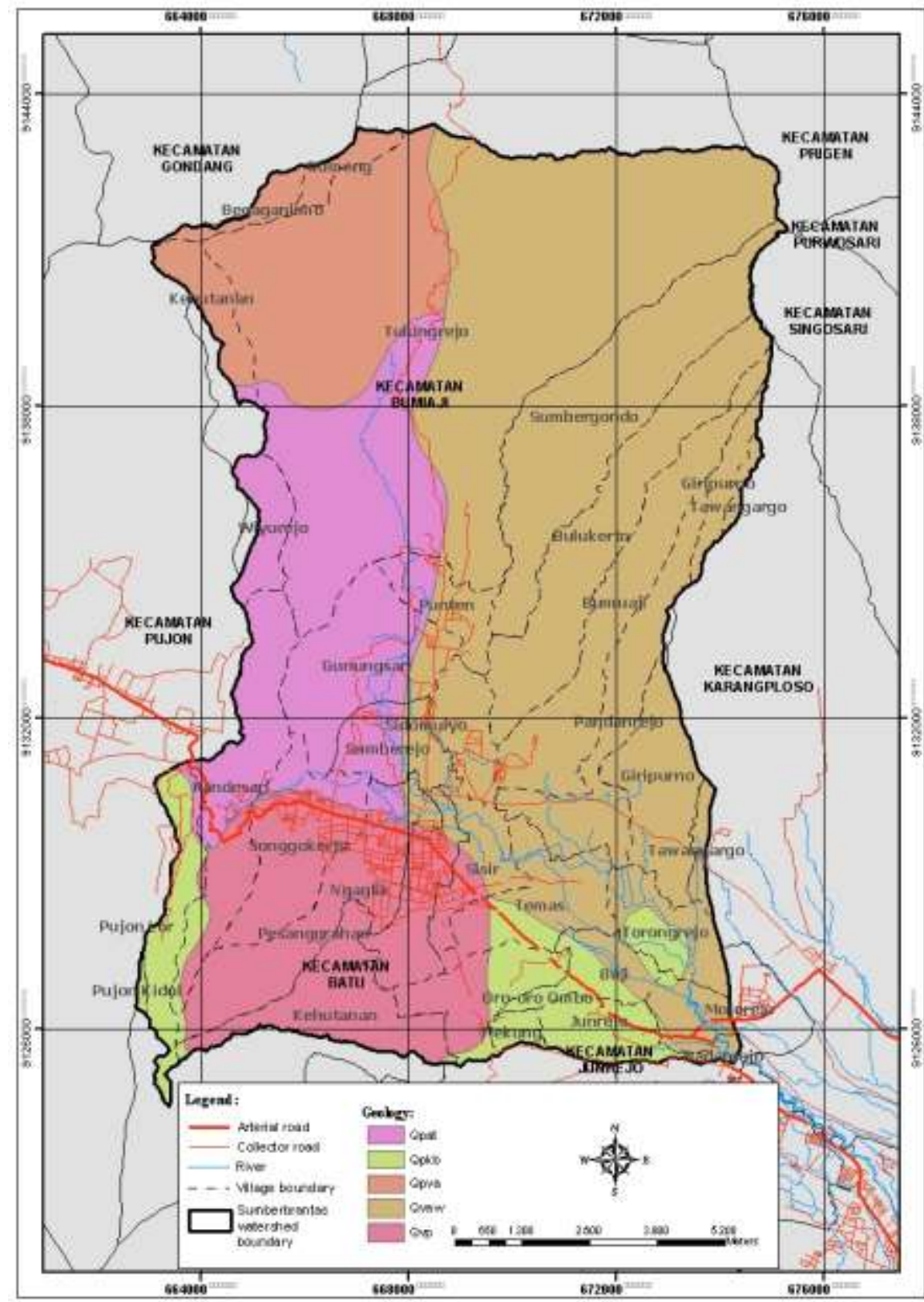

Qpvkb Kawi-Butak Volcanic Product

Qpva Young Anjasmara Volcanic Product

Qvaw Arjuna-Welirang Volcanic Product

Qvp

Panderman Volcanic Product

Gambar 2.9. Peta geologi DAS Sumber Brantas

\section{Kondisi Landform}

Kondisi geologi dan proses pembentukan lahan menghasilkan bentuk lahan yang dipengaruhi oleh proses vulkanisme. Berdasarkan reliefnya, bentuk lahan di Kota Batu dapat dibagi menjadi empat macam, yaitu: (1) jalur pelembahan sempit (Ac) dan jalur aliran lahar (Al), (2) dataran $(\mathrm{P})$, (3) perbukitan $(\mathrm{H})$, dan (4) pegunungan $(\mathrm{M})$, dimana, berdasarkan posisinya pada suatu lereng dan kemiringan lerengnya, masih dapat dibagi lagi menjadi berbagai macam bentuk lahan. Sebaran masing-masing bentuk lahan disajikan pada Gambar 2.10. 


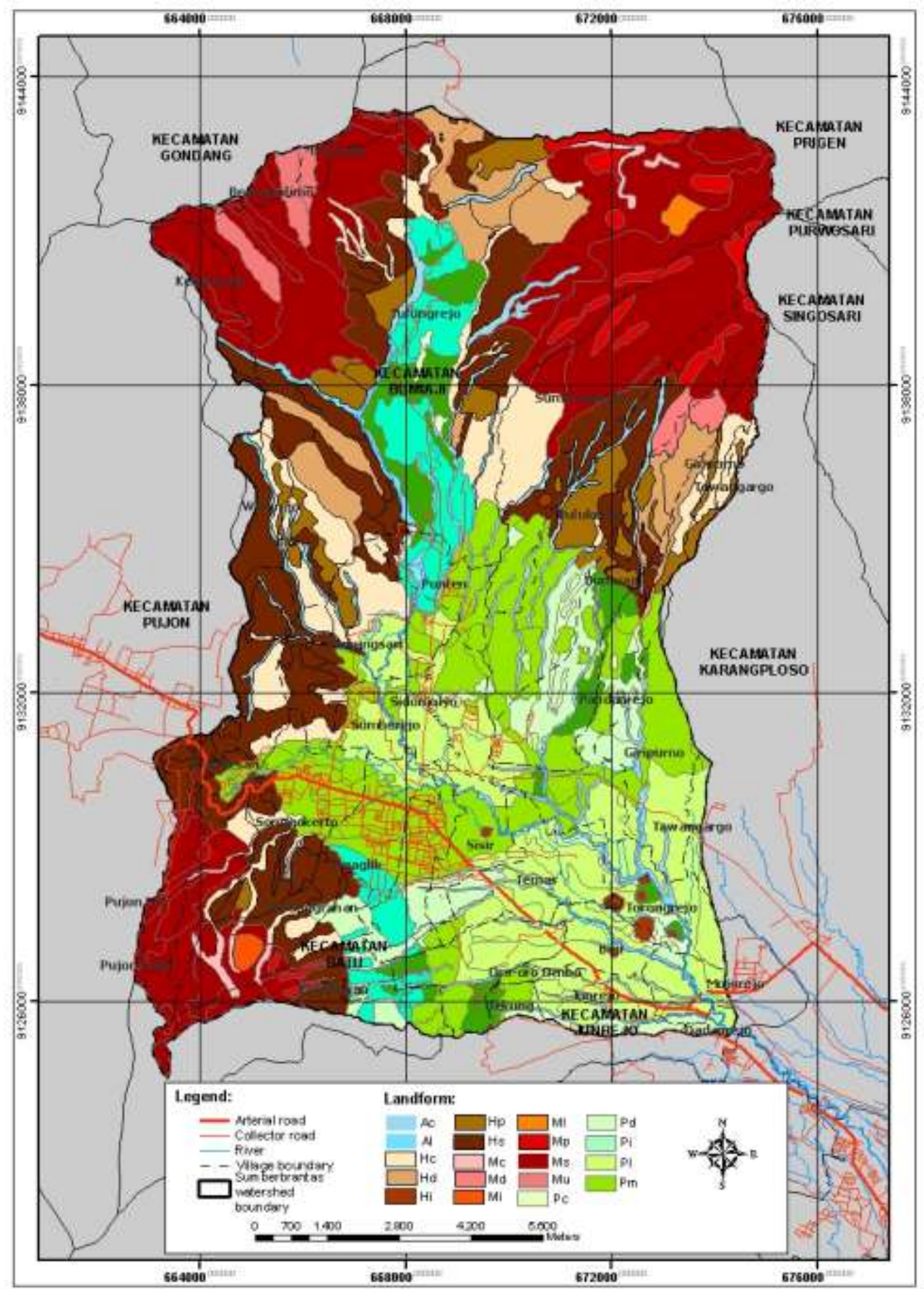

Gambar 2.10. Peta landform DAS Sumber Brantas

Jalur perlembahan tersebar di seluruh lokasi merupakan hasil proses denudasional/ pengikisan dari bentuk lahan asalnya. Pada beberapa jalur, ditumpuki oleh sedimentasi lahar tua atau debris. Kedalaman, lebar dan bentuknya tergantung lokasi jalur ini. Di bagian lereng atas pegunungan umumnya cukup lebar dan dalam dengan lemah bentuk V. Di bagian dataran, tidak terlalu lebar, tidak terlalu dalam dan berbentuk $\mathrm{U}$. 
Sistem dataran dijumpai di bagian tengah, merupakan dataran vulkanik antar pegunungan yang terbentuk oleh berbagai bahan hasil letusan dan atau sedimentasi hasil erosi dan atau longsor dari kawasan perbukitan/ pegunungan di atasnya. Berdasarkan atas posisi dan proses pegikisan yang dapat dibagi lagi ke beberapa subsistem, yaitu: dataran bagian bawah $(\mathrm{Pl})$, bagian tengah $(\mathrm{Pm})$, bagian atas $(\mathrm{Pu})$, dataran yang tertoreh $(\mathrm{Pd})$ dan bagian dataran yang mengalami erosi berlebihan (Ps).

Sistem perbukitan dijumpai di bagian lereng tengah atau kaki kompleks pegunungan yang ada di sekitarnya. Relief perbukitan memiliki amplitudo ketinggian antara 50-300m. Berdasarkan atas posisi dan kemiringan lerengnya dapat dibedakan atas: puncak/ punggung perbukitan (Hp), pereng perbukitan (Hs), kaki perbukitan (Hc), dan lereng perbukitan yang tertoreh ( $\mathrm{Hd})$.

Sistem Pegunungan berapa di bagian lereng atas kompleks pegunungan yang ada, yaitu Gunung Arjuna-Welirang, Anjasmara dan Kawi-Butak. Berdasarkan atas konfigurasi permukaannya, grup ini dapat dikelompokkan menjadi beberapa kelompok, yaitu: Plato, spurs dan punggung gunung (Mp), kerucut gunung vulkanik pada bagian lereng atas $(\mathrm{Mu})$, lereng-lereng gunung curam (Ms), bahan tertimbun akibat longsoran di gunung (Mc ), gunung tertoreh dengan punggung tajam sejajar (Md), Kerucut gunung vulkanik terisolir, curam sampai sangat curam (Mi), dan bekas longsoran tanah di gunung (Ml).

\section{Kondisi Lereng}

Kemiringan lereng di DAS Sumber Brantas sangat bervariasi dari datar sampai sangat curam. Lereng datar dijumpai pada dataran antar gunung api di bagian tengah, termasuk dataran sempit antara Gunung Arjuna dan Anjasmara. Lereng terjal umumnya dijumpai pada tebing lereng hampir di semua lokasi. Lereng datar sampai agak datar $(<8 \%)$ sekitar $19.18 \%$ luas areal berada pada dataran vulkanik antar pegunungan. Sebagian besar berada di Kecamatan Junrejo dan Batu dan sebagian kecil di Kecamatan Bumiaji. Di Kecamatan Bumiaji biasanya diusahakan untuk tanaman pangan (padi dan jagung), sedangkan di Kecamatan Batu dan Bumiaji untuk tanaman sayuran. Lereng landai (8-15\%) sekitar 16.8\% luas wilayah pada dataran berombak di kaki perbukitan yang dimanfaatkan untuk lahan budidaya (tanaman pangan di Kecamatan Bumiaji dan Batu), dan sayuran dan/ atau buah-buahan di Kecamatan Bumiaji. Lereng agak curam (15$25 \%$ ) sekitar $15.45 \%$ luas wilayah pada dataran berombak-bergelombang di kaki perbukitan yang budidaya tanaman pangan dan kebun campuran (Kecamatan Junrejo dan Batu) dan kebun apel dan/ atau sayuran di Kecamatan Bumiaji. Lereng curam (25-40) sekitar $15.47 \%$ luas wilayah pada kawasan kaki perbukitan atau tebing lembah yang ada di DAS Sumber Brantas. Penggunaan lahan berupa kebun campuran, tanaman pangan atau sayuran. Lereng sangat curam sampai terjal (>40\%) sekitar $33.10 \%$ dijumpai di kawasan perbukitan pegunungan dan tebing sungai. Lahan ini umumnya berupa hutan, semak belukar atau bambu (di pinggir sungai di kawasan budidaya). 


\section{Kondisi Jenis Tanah}

Tanah yang terbentuk cukup bervariasi dari tanah-tanah muda sampai tanah yang cukup tua. Tanah muda (Entisol) dijumpai pada di jalur pelembahan atau lereng pegunungan yang memiliki solum tanah sangat dangkal. Andisol dijumpai di lereng atas dan tengah pegunungan yang ada di sekeliling DAS Sumber Brantas. Inseptisol dijumpai pada hampir seluruh lahan dataran dan beberapa lokasi di lereng pegunungan. Molisol umumnya merupakan tanah-tanah Inceptisol yang memiliki warna hitam di permukaan, sehingga umumnya dijumpai pada dataran bergelombang di kawasan hutan. Alfisol umumnya dijumpai pada dataran di kaki-kaki perbukitan di Sekitar Kota Batu. Sebaran jenis tanah disajikan pada Gambar 2.12.

\section{Penciri (atribut) Hidrologi}

Sesuai dengan bahan induk pembentuk Lansekap dan penyusun tanahnya, maka karakteristik hidrologi DAS Sumber Brantas dapat dibedakan atas tiga kelompok (Gambar 2.13). Ketiga kelompok karakteristik hidrologi tersebut dijelaskan sebagai berikut:

\section{a. Bagian Timur Laut (Lereng Gunung Arjuna)}

Aliran sungai radian berasal dari puncak kerucut Gunung Arjuna. Punggung bukit dan lembah sungai memanjang dari puncak sampai bagian kaki perbukitan, dengan pola drainase dendritik agak parallel. Pola drainase dikontrol oleh proses volkanisme yang berupa stratovolcano, sehingga membentuk sungai memanjang dari puncak kerucut gunung api sampai bagian dataran. Batuan singkapan pada bagian atas menyebabkan limpasan permukaan cukup tinggi di wilayah ini, untungnya mulai lereng tengah ke bawah tumpukan material tufa vulkanik cukup tebal sehingga resapan air cukup tinggi. Pada kenyataannya, tidak banyak mata air yang muncul pada lereng pegunungan ini. 


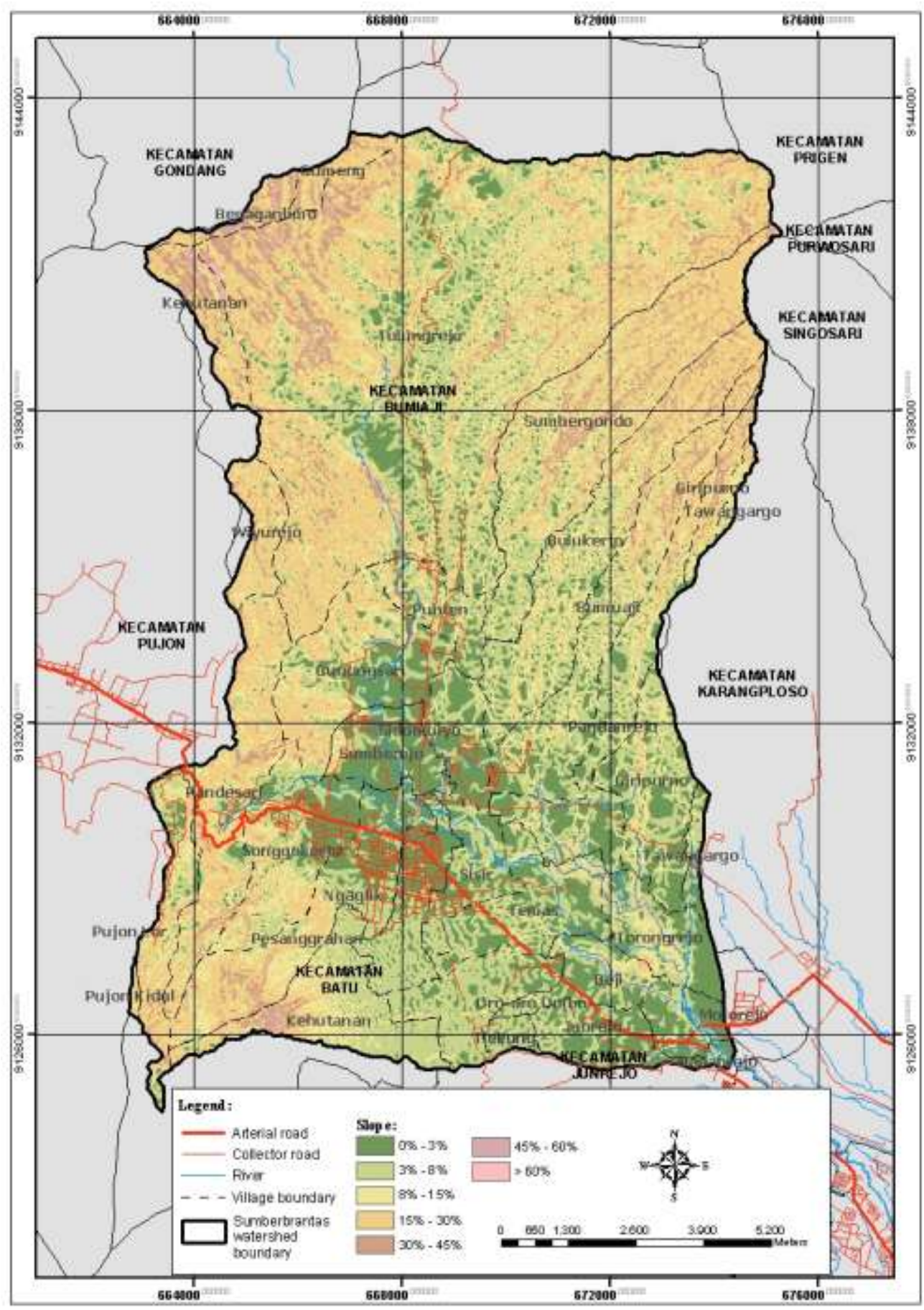

Gambar 2.11. Peta kelerengan DAS Sumber Brantas 


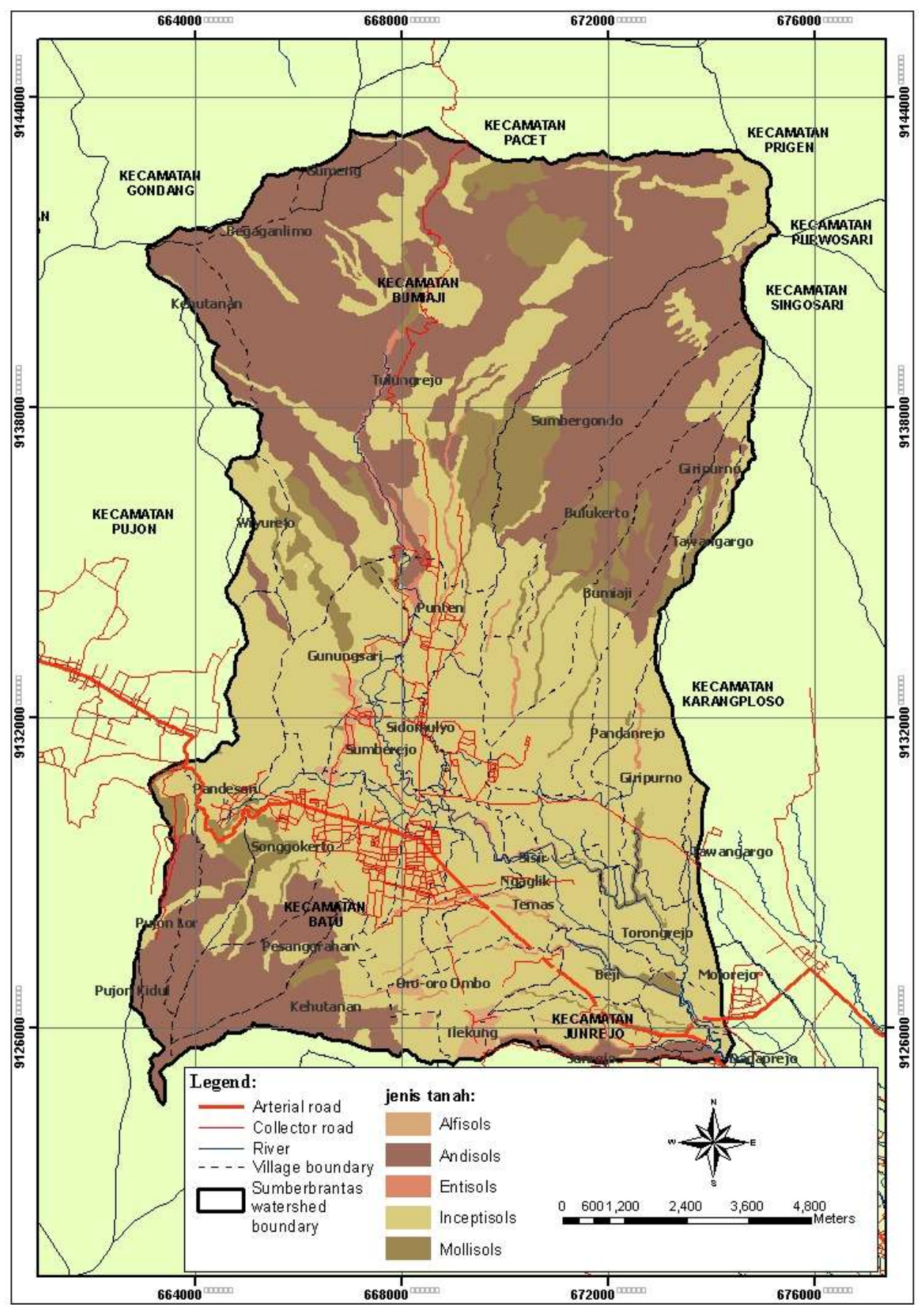

Gambar 2.12. Peta jenis tanah DAS Sumber Brantas 


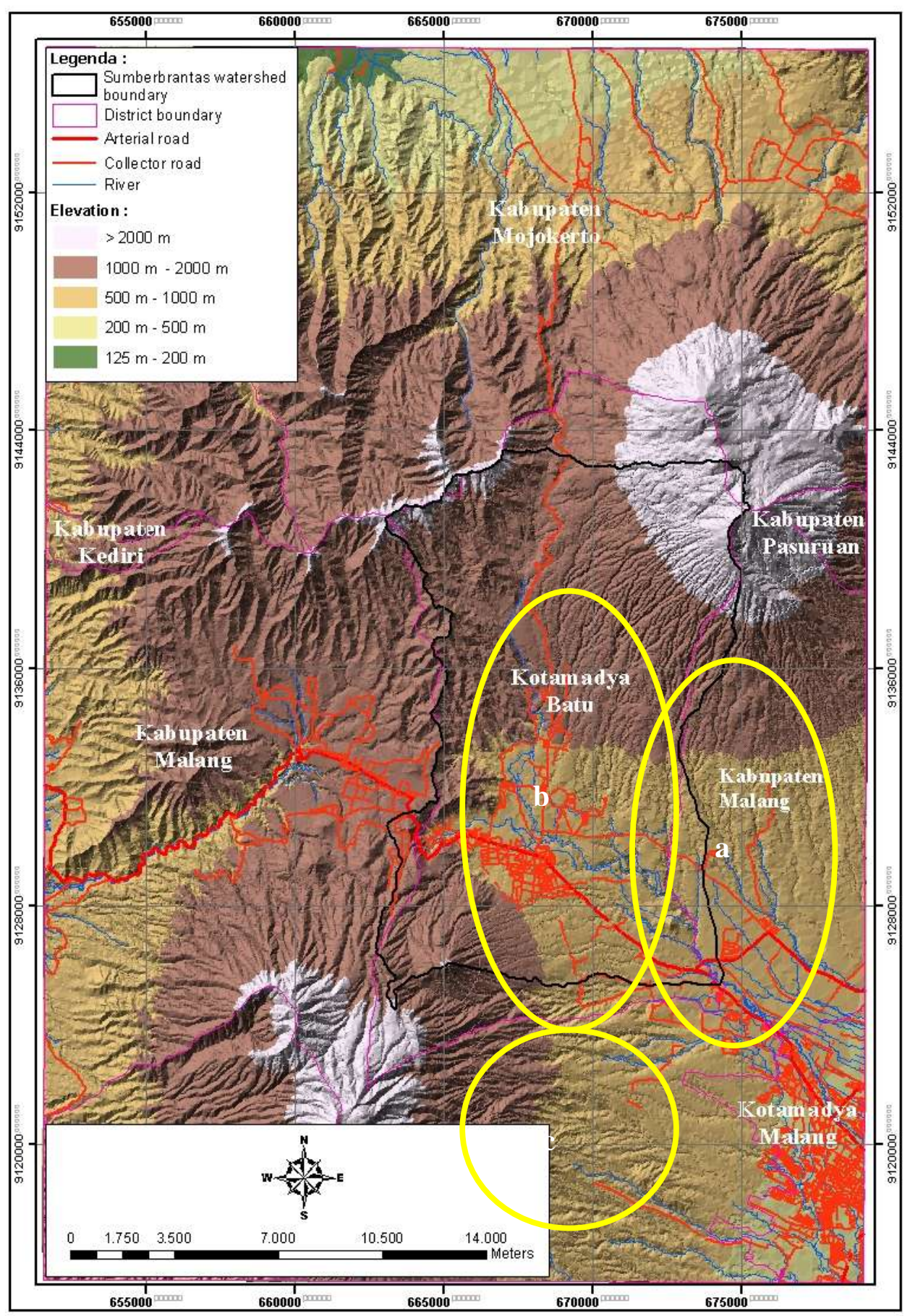

Gambar 2.13. Peta pembagian pola drainase sebagai pengaruh dari kondisi geologi di DAS Sumber Brantas 
b. Bagian Barat (Lereng Gunung Anjasmara),

Batuan yang berasal dari leleran lava menyebabkan terdapatnya batuan impermeable di bagian bawah lapisan tufa vulkanik di sebagian besar lereng ini. Relief lebih kasar karena sifat bahan induk dan proses perusakan krucut vulkanik oleh gempa vulkanik di masa yang lampau. Pola drainase dendritik dengan panjang sungai tidak terlalu panjang pada lembah dalam dan curam. Pada kenyataannya, banyak dijumpai mata air dari kawasan ini.

c. Bagian Selatan (Lereng Gunung Panderman dan Kawi)

Pola drainase dendritik berasal dari kaki Gunung Kawi-Butak dan Panderman. Tanah solum dangkal dengan batuan kokoh di bagian bawah menyebabkan sebagian besar air hujan akan mengalami mengalir di permukaan. Tanah dalam umumnya yang dipengaruhi oleh bahan dari Gunung Kawi-Butak. Mata air yang muncul di wilayah ini lebih banyak dipengaruhi oleh Gunung Kawi dan Butak.

Sementara itu, atribut-atribut hidrologi DAS Sumber Brantas yang dihasilkan dari peta DEM ditunjukkan pada gambar 2.14. Terdapat 15 subDAS dengan daftar dan luasan seperti yang disajikan pada Tabel 2.4 .

Table 2.4. Luas subcatchment di DAS Sumber Brantas

\begin{tabular}{ccc}
\hline & & Area \\
Subcatctment ID & Ha & $\%$ \\
\hline 1 & 876.788 & 5.06 \\
2 & 1850.898 & 10.67 \\
3 & 1520.337 & 8.77 \\
4 & 129.836 & 0.75 \\
5 & 1076.827 & 6.21 \\
6 & 740.345 & 4.27 \\
7 & 1327.340 & 7.65 \\
8 & 2162.346 & 12.47 \\
9 & 793.625 & 4.58 \\
10 & 962.241 & 5.55 \\
11 & 1090.600 & 6.29 \\
12 & 440.990 & 2.54 \\
13 & 1895.813 & 10.93 \\
14 & 1151.678 & 6.64 \\
15 & 1324.116 & 7.63 \\
\hline Total & 17343.780 & 100 \\
\hline
\end{tabular}




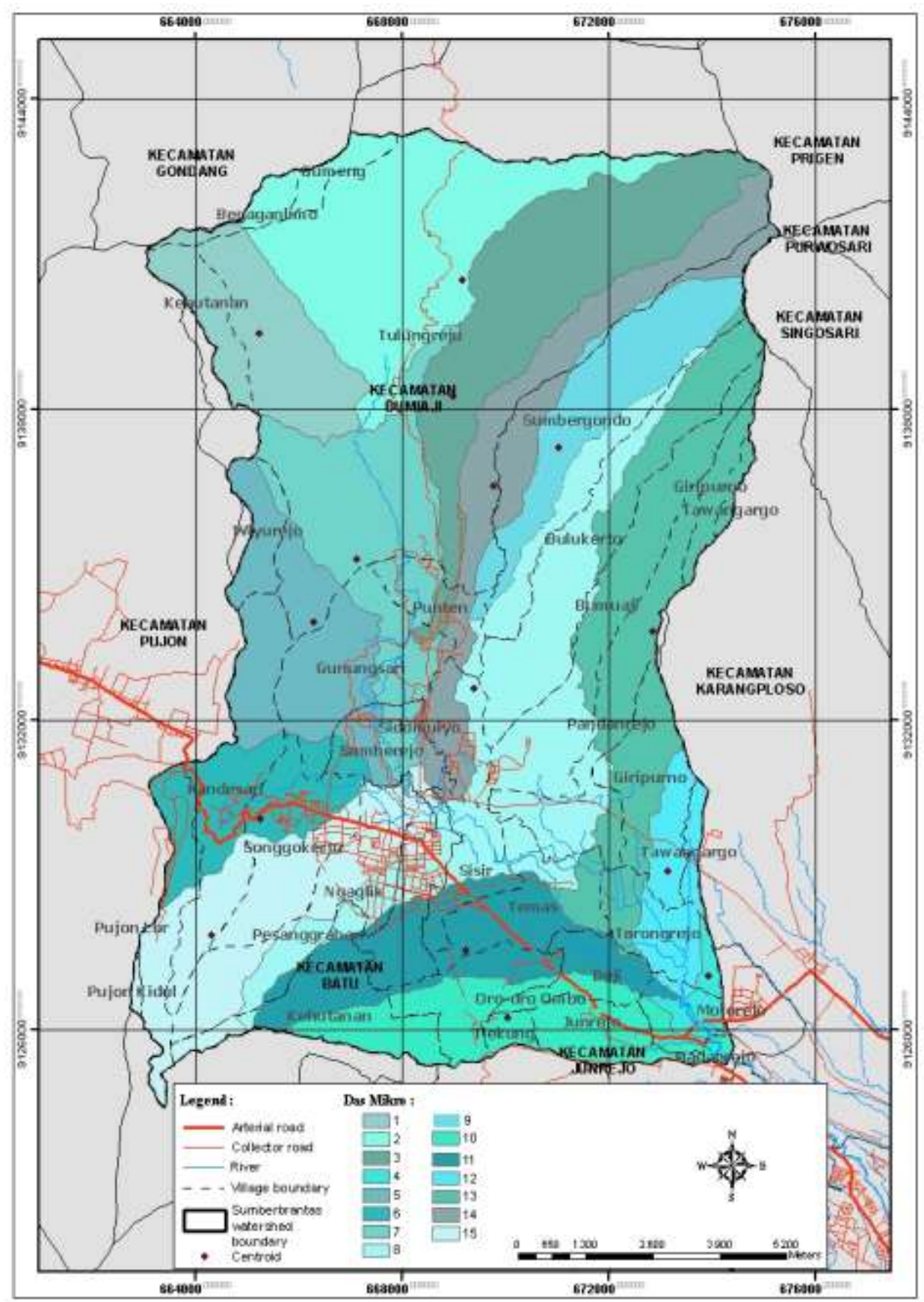

Gambar 2.14. Peta pembagian subcatchment di DAS Sumber Brantas 
Routing distance dari setiap subDAS ke outlet DAS di ujung Sungai Brantas di Pendem disajikan pada Tabel 2.5.

Table 2.5. Routing distance dari titik tengah subcathment ke outlet sungai Brantas di Pendem

\begin{tabular}{cc}
\hline Subcatctment ID & RoutDist-Pendem $(\mathbf{k m})$ \\
\hline 1 & 21.319 \\
2 & 24.090 \\
3 & 19.269 \\
4 & 2.149 \\
5 & 16.176 \\
6 & 15.117 \\
7 & 16.179 \\
8 & 11.184 \\
9 & 17.770 \\
10 & 4.529 \\
11 & 6.418 \\
12 & 4.974 \\
13 & 10.462 \\
14 & 11.081 \\
15 & 15.202 \\
\hline
\end{tabular}

\subsubsection{Klasifikasi Penutupan Lahan di DAS Sumber Brantas}

Hasil dari proses klasifikasi penutupan lahan dengan metode hierarki adalah peta penutupan lahan di DAS Sumber Brantas, Jawa Timur. Luas setiap penggunaan lahan di DAS Sumber Brantas pada tahun 1989 dan 2002 disajikan pada Tabel 2.6. Sedangkan penyebaran setiap penggunaan lahan pada tahun 1989 dan 2002 berturut-turut disajikan pada Gambar 2.16 dan 2.17 .

Tabel 2.6. Luas penggunaan lahan di DAS Sumber Brantas.

\begin{tabular}{llcrrr}
\hline \multirow{2}{*}{ No } & Landuse & \multicolumn{2}{c}{$\mathbf{1 9 8 9}$} & \multicolumn{2}{c}{$\mathbf{2 0 0 2}$} \\
& & Ha & Ha & \multicolumn{1}{c}{$\%$} \\
\hline 1 & Ricefield & 714.15 & 4.11 & 672.39 & 3.87 \\
2 & Dryland & $1,655.55$ & 9.52 & $2,297.97$ & 13.22 \\
3 & Garden & $4,023.60$ & 23.14 & $2,928.42$ & 16.84 \\
4 & Natural Forest & $5,357.16$ & 30.82 & $4,034.52$ & 23.21 \\
5 & Production Forest & $1,222.47$ & 7.03 & $1,655.64$ & 9.52 \\
6 & Shurb & $2,332.26$ & 13.42 & $3,742.38$ & 21.53 \\
7 & Bareland & 31.85 & 0.18 & 25.83 & 0.15 \\
8 & Settlement & 240.57 & 1.38 & $1,346.67$ & 7.75 \\
9 & No Data (Cloud and Shadow & 1.806 .90$. & 10.39 & 680.69 & 3.91 \\
\hline
\end{tabular}

Selama 13 tahun terdapat beberapa perubahan penggunaan lahan. Beberapa macam penggunaan lahan mengalami penurunan yang cukup nyata, yaitu kebun dan hutan alami. Sedangkan beberapa penggunaan lahan mengalami peningkatan luasan, antara lain: tegalan, hutan produksi, 
semak belukar dan pemukiman. Secara spasial perubahan ini cukup rumit dari satu bentuk penggunaan ke bentuk penggunaan yang lain. Perubahan penggunaan lahan pada tahun 1989 dan 2002 disajikan pada Gambar 2.15.

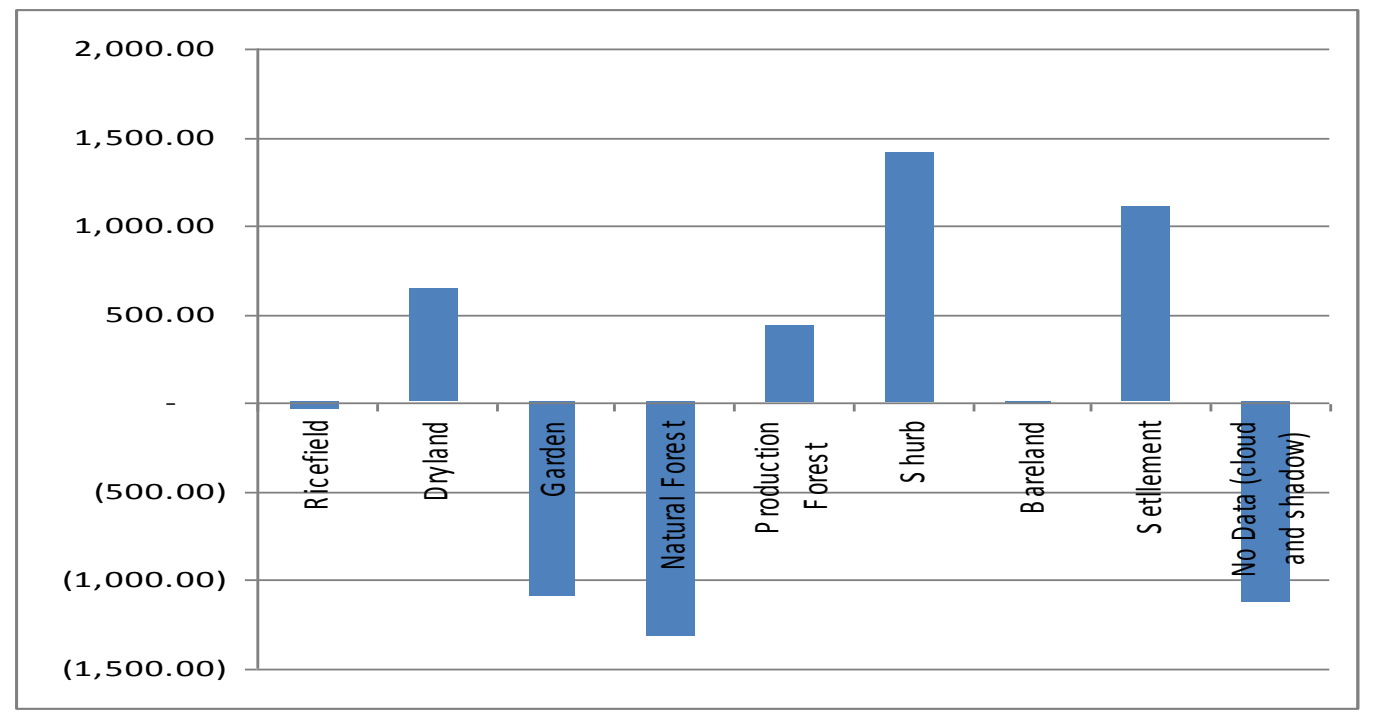

Gambar 2.15. Perubahan penggunaan lahan antara tahun 1989 ke tahun 2002.

Tersedianya citra yang diambil pada waktu yang berbeda, dimana citra tahun 1989 direkam pada bulan Februari (musim basah), sedangkan citra tahun 2002 direkam pada bulan Agustus. Terlepas dari adanya alihguna lahan yang memang banyak terjadi di kawasan ini, kondisi ini juga berdampak pada luasnya lahan bervegetasi (daun penuh) pada tahun 1989 dan daun gugur pada tahun 2002. Berkurangnya luas kebun (apel dan jeruk) tampaknya karena pengaruh hal ini, karena pada bulan-agustus banyak apel yang sudah selesai masa panen dan mengalami perompesan sehingga terkesan tidak bervegetasi.

Gambar 2.18 menunjukkan bahwa landuse utama di DAS Sumber Brantas adalah lahan sawah $(3.87 \%)$, tanaman pertanian (agricultural land $=13.22 \%$ dan kebun $=16.84 \%$ ) serta hutan (hutan alami $=9.37 \%$, hutan terganggu $=13.84 \%$ dan agroforestry berbasis pohon $=9.52 \%$ )

Lahan sawah umumnya dijumpai pada wilayah datar di bawah ketinggian 800m di Kecamatan Junrejo dan Batu. Wilayah datar yang tidak cukup mendapatkan air hujan biasanya digunakan sebagai lahan tegalan dengan tanaman ketela atau jagung. Wilayah datar dengan ketinggian lebih $800 \mathrm{~m}$ banyak digunakan untuk budidaya sayuran dan/ atau bunga. 


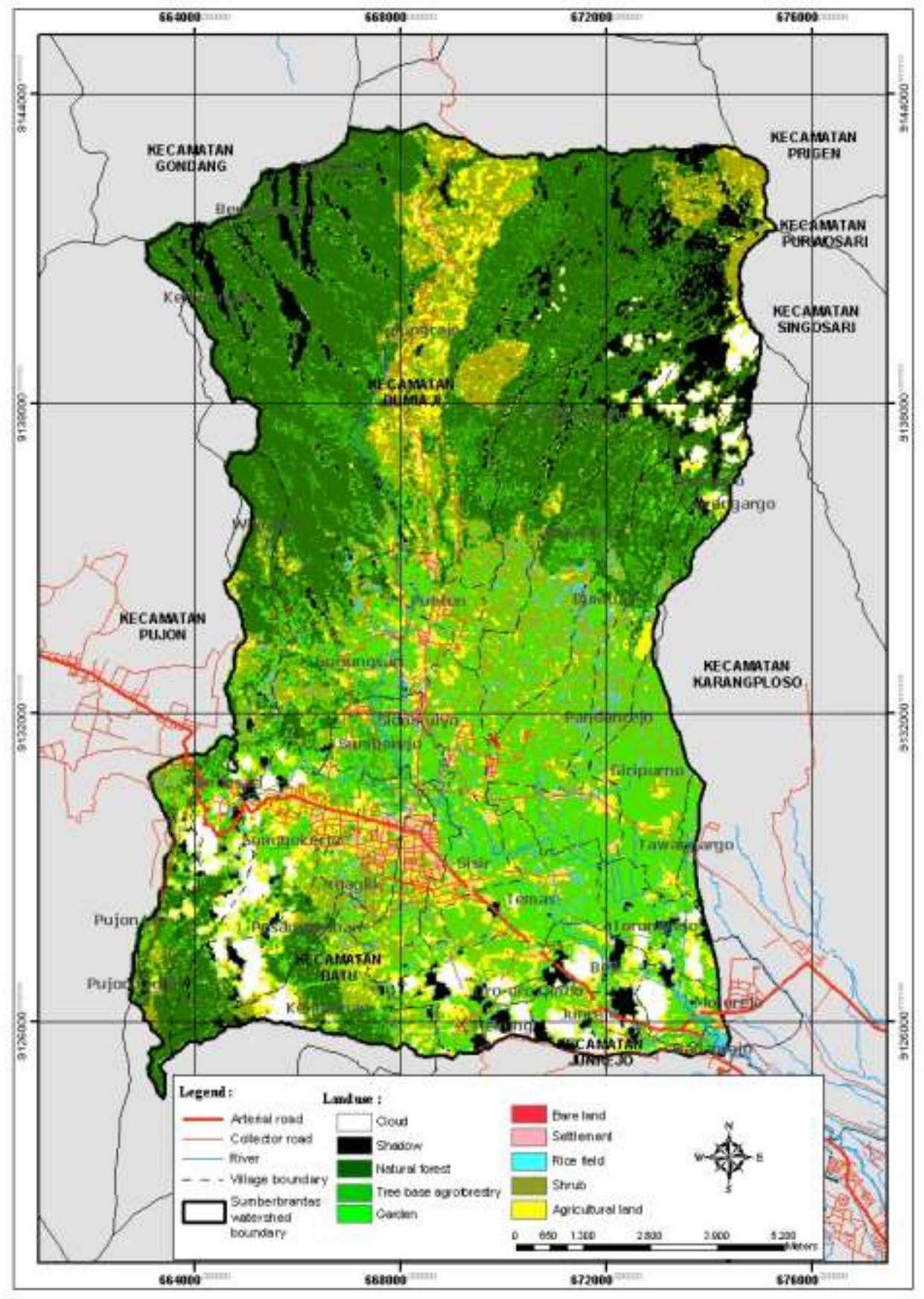

Gambar 2.16. Penggunaan lahan pada tahun 1989 di DAS Sumber Brantas 


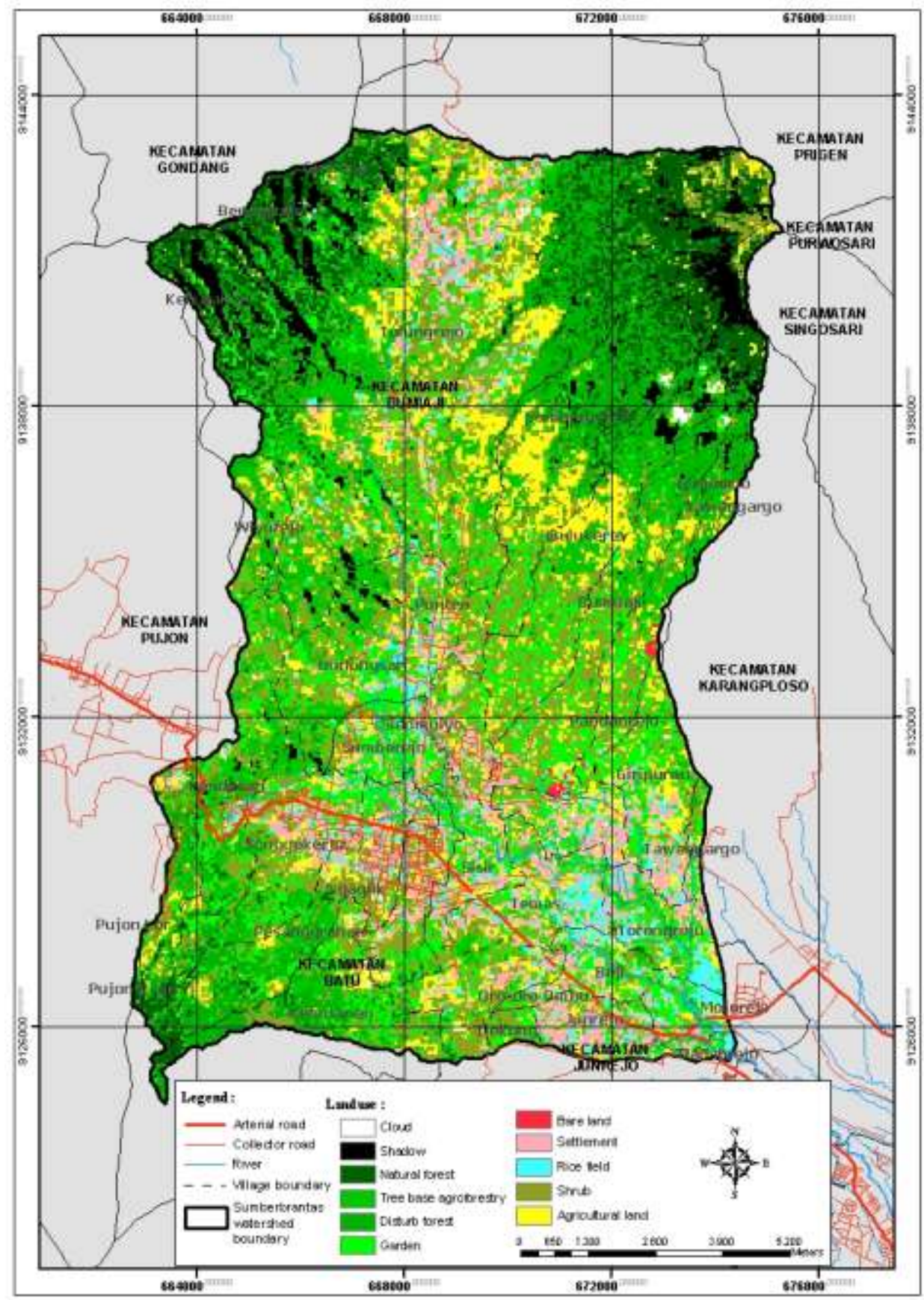

Gambar 2.17. Peta penggunaan lahan pada tahun 2002 di DAS Sumber Brantas

Sayuran seperti kobis, wortel, kacang-kacangan banyak diusahakan pada dataran berombakbergelombang dengan ketinggian antara 800-1000m di Kecamatan Batu dan Bumiaji bagian bawah. Sedangkan kentang bisanya ditanam pada lahan berombak dan bergelombang dengan ketinggian lebih dari 1000m, khususnya di Kecamatan Bumiaji.

Kebun campuran dengan aneka tanaman kayu-kayuan dan buah-buahan banyak dijumpai pada kawasan dataran bergelombang atau perbukitan dengan lereng curam (>25\%) di lereng Gunung 
Panderman di bagian selatan DAS Sumber Brantas. Pada lereng Gunung Arjuna dan Anjasmara umumnya, kalau tidak lahan kering dengan tanaman sayuran biasanya berupa hutan produksi.

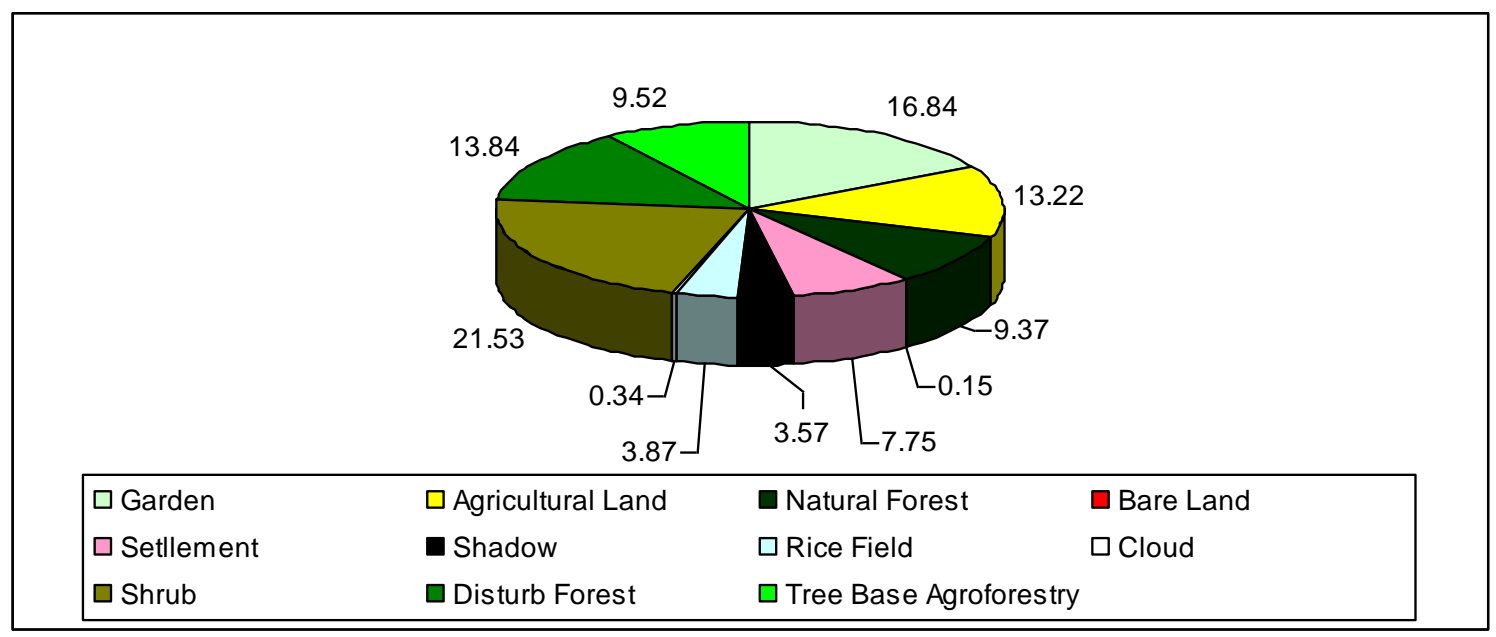

Gambar 2.18. Penggunaan lahan di DAS Sumber Brantas tahun 2002

Di bawah tegakan tanaman muda pada hutan produksi biasanya juga ditanami sayuran dan atau tanaman pangan sampai kanopi tanaman kayu-kayuan cukup rapat. Penggunaan lahan monokultur dengan pemberian pupuk yang tidak seimbang menyebabkan terjadinya degradasi kesuburan tanah. Hal ini ditandai dengan semakin tingginya jumlah pupuk, baik pupuk yang diberikan melalui tanah maupun yang diberikan melalui penyemprotan daun. Untungnya, bahan induk yang berupa bahan vulkanik yang memiliki kandungan hara tinggi masih memiliki cadangan hara yang cukup tinggi. Sebagian besar kebun apel ditengarai telah mengalami degradasi kesuburan tanah, meskipun secara fisik masih cukup baik bagi berbagai usaha tani.

Selain karena usaha tani monokultur dengan pemberian pupuk yang tidak seimbang, degradasi tanah di wilayah ini juga disebabkan oleh erosi dan longsor karena penggunaan lahan yang tidak sesuai dengan daya dukungnya. Erosi dan longsor cukup tinggi di wilayah ini, khususnya di Kecamatan Bumiaji yang memiliki lahan dengan kemiringan cukup curam dan digunakan untuk budidaya tanaman kentang. Kentang yang tidak menghendaki genangan, menyebabkan air hujan sebagian besar melimpas di permukaan sehingga menyebabkan terjadinya erosi dan longsor teras.

\subsubsection{Accuracy Assesment}

Secara khusus tidak dilakukan pengujian akurasi hasil interpretasi citra dengan kenyataan di lapangan. Tetapi, jika dilakukan pengujian terbalik dari titik-titik pengujian penggunaan lahan di lapangan menunjukkan bahwa akurasi hasil analisis adalah $67 \%$. 


\section{Local Ecological Knowledge (LEK)}

\subsection{Metode}

\subsubsection{Tujuan Survei LEK}

Tujuan umum survei LEK (Local Ecological Knowledge) dalam konteks pelaksanaan RHA (Rapid Hydrological Appraisal) di DAS Sumber Brantas adalah untuk memahami dan merumuskan pengetahuan, pengalaman dan persepsi yang dimiliki oleh komunitas lokal (masyarakat Kota Batu) yang mempunyai pengaruh langsung terhadap pengelolaan DAS Sumber Brantas.

Sementara itu, tujuan spesifik dari pelaksanaan survei LEK di DAS Sumber Brantas ini adalah:

- Menerapkan metode cepat untuk memahami isu utama, masalah serta pemahaman dan pengetahuan terkait dengan hidrologi diantara stakeholder lokal khususnya masyarakat Kota Batu

- Untuk menguji metode RHA yang akan diterapkan di DAS Sumber Brantas dalam konteks fungsi hidrologi DAS.

\subsubsection{Tahapan Survei LEK}

Tahapan kegiatan survei LEK di DAS Sumber Brantas dilaksanakan sesuai dengan metode yang dikembangkan World Agroforestry Centre - ICRAF, namun disesuaikan dan mengikuti dinamika situasi masyarakat Kota Batu. Tahapan kegiatan survei LEK adalah sebagai berikut:

1. Pelingkupan (scoping)

Kegiatan-kegiatan yang dilaksanakan dalam tahap scoping ini meliputi:

a. Sosialisasi program kepada masyarakat.

Anggota peneliti dalam tim survei RHA ini pada umumnya sudah mengenal dengan baik kawasan DAS Sumber Brantas karena telah sering mengadakan kegiatan dan penelitian di kawasan ini sejak beberapa tahun lalu. Oleh sebab itu, pengenalan terhadap wilayah dan masyarakat kawasan DAS Sumber Brantas oleh para peneliti sudah sangat baik. Namun demikian, adanya kegiatan baru seperti survei RHA ini perlu diperkenalkan dan disosialisikan kepada tokoh-tokoh masyarakat di Kota Batu serta desa-desa yang akan dipilih sebagai lokasi penelitian. 
Kegiatan ini memerlukan waktu 2 - 3 hari untuk mengunjungi beberapa desa yang dianggap penting dan menemui tokoh-tokoh masyarakat setempat.

b. Pemahaman wilayah survei

Sebagaimana disebutkan, para peneliti sudah memiliki pengalaman cukup banyak di kawasan DAS Sumber Brantas, sehingga pemahaman wilayah ini dilakukan untuk mempertajam pandangan peneliti terkait dengan RHA. Salah satu upaya yang dilakukan adalah melakukan studi data sekunder dan laporan-laporan kegiatan yang sudah pernah dilakukan. Sebagaimana biasa dijumpai diberbagai lokasi lain, kesulitan utama dalam tahap ini adalah mencari dan mengumpulkan dokumen yang diperlukan. Dokumen-dokumen penting seringkali tidak tersimpan secara baik, sehingga sulit menemukannya kembali. Demikian pula tempat atau lokasi penyimpanan domuken-dokumen yang dibutuhkan itu tersebar pada berbagai instansi dan personil di instansiinstansi tersebut.

Proses pemahaman wilayah dan masyarakat terkait dengan isu hidrologi dikuti oleh penetapan strategi pelaksanaan survei RHA, meliputi penetapan Sub DAS dan desa pewakil, menyiapkan peta-peta, dokumen yang relevan beserta kelengkapannya, dan menyiapkan proses pemilihan stakeholder. Upaya mengumpulkan bahan dan dokumen yang relevan untuk studi RHA ini memakan waktu yang lumayan banyak. Total waktu yang diperlukan untuk kegiatan ini, mengumpulkan bahan dan dokumen serta mempelajari dan mendiskusikan dalam tim memakan waktu sekitar 20 hari.

c. Persiapan peta dan dokumen penunjang Persiapan berikutnya adalah menyediakan peta-peta, foto udara dan citra satelit yang relevan dengan lokasi studi. Dalam kegiatan lain yang pernah dilakukan oleh para peneliti, sudah dibuat peta-peta manual dan digital untuk wilayah DAS Sumber Brantas. Kegiatan persiapan peta-peta, foto udara, citra satelit serta dokumen pendukungnya ditujukan untuk menyesuaikan dengan tema RHA.

DAS Sumber Brantas dibagi-bagi menjadi bagian-bagian lebih kecil menurut hirarki Sub-DAS, Sub-sub-DAS, dan seterusnya sehingga diperoleh wilayah yang paling kecil dan homogen dinamakan DAS Mikro. DAS Sumber Brantas dibagi menjadi 15 Sub-DAS dan selanjutnya dibagi lagi menjadi sekitar 43 buah DAS Mikro, yang masing-masing luasnya antara 15ha sampai 250ha.

Dalam penyiapan peta, foto udara dan citra satelit ini sekaligus juga dilakukan identifikasi dan pemilihan lokasi DAS mikro yang representatif untuk survei RHA. Dalam tahapan ini dipilih DAS Mikro Talun yang 
melewati Dusun Kekep, salah satu wilayah Desa Tulungrejo, Kecamatan Bumiaji, Kota Batu, sebagai lokasi kegiatan survei LEK.

Kegiatan ini secara keseluruhan memerlukan waktu sekitar 5 hari kerja.

d. Identifikasi stakeholder kunci

Berdasarkan informasi dan diskusi dari tokoh-tokoh masyarakat khususnya di desa Tulungrejo, Kecamatan Bumiaji dan pengalaman peneliti bekerja-sama dengan berbagai pihak di Kota Batu, maka peneliti dapat memetakan stakeholder lokal yang relevan dalam kegiatan RHA ini. Beberapa kelompok stakeholder yang dapat diidentifikasi adalah petani, pengusaha, tokoh desa, dan LSM lokal, termasuk di dalamya adalah tokoh-tokoh perempuan. Stakeholder terbesar adalah petani, yang tergabung dalam berbagai kelompok menurut kegiatan atau wilayah kerjanya. Dua kelompok utama stakeholder petani adalah kelompok petani hutan (LMDH) dan kelompok petani di luar kawasan hutan. Jika dilihat dari komoditas yang diusahakan, maka petani di kawasan budidaya dapat dibedakan menjadi beberapa kelompok lagi misalnya kelompok tani bunga, kelompok tani buah, kelompok tani anekatanaman dan kelompok peternak sapi perah. Namun seringkali seorang petani memiliki beberapa macam usaha tani sekaligus, sehingga bisa termasuk dalam beberapa kelompok tani itu. Sebagian anggota kelompok tani ini juga menjadi anggota kelompok atau asosiasi petani pemakai air atau yang dikenal dengan HIPPA (Himpunan Petani Pemakai Air).

Kelompok stakeholder berikutnya yang perlu mendapat perhatian menyangkut isu hidrologi dan pengelolaan DAS adalah para pengusaha kecil di tingkat desa. Mereka umumnya tidak tergabung dalam kelompok formal, tetapi peran mereka mungkin sangat penting. Beberapa contoh pengusaha kecil skala rumah tangga misalnya pengusaha atau pemilik usaha industri seperti pabrik tahu, pembuat janggelan, pembuatan makanan dan minuman kemasan (keripik, sari buah, dsb), pengusaha warung, villa atau penginapan, dsb. Dalam kelompok ini juga dimasukkan HIPPAM (organisasi pengelola air minum tingkat desa).

Sementara itu di Kota Batu terdapat beberapa Lembaga Swadaya Masyarakat lokal yang memiliki kegiatan di bidang lingkungan hidup. Beberapa LSM yang cukup sering terdengar memiliki kegiatan bersama masyarakat adalah Fokal Mesra, Serikat Petani Gunung Biru (SPGB), Yayasan Pusaka, Yayasan Kali Watu dan sebagainya. Dengan pertimbangan jangkauan kegiatan dan tingkat kemampuan SDM yang dimiliki, maka LSM di Kota Batu dimasukkan kedalam kelompok stakeholder tingkat Kota Batu. 


\begin{tabular}{ll}
\hline Kelompok Stakeholder & Anggota \\
\hline Petani & \\
- Petani Hutan & Pesanggem atau petani penggarap lahan di hutan kelompok \\
& LMDH (Lembaga Masyarakat Desa Hutan), peternak sapi \\
& perah \\
& Petani sayur, petani bunga, petani buah (apel, dsb), peternak \\
& sapi perah, HIPPA \\
& Pengusaha : wisata, hotel dan restoran (PHRI), air minum \\
& (PDAM, HIPPAM), jamur, industri rumah tangga (pabrik tahu, \\
& janggelan, minuman, dsb). \\
Pengusaha & Fokal Mesra, Serikat Petani Gunung Biru (SPGB), Kali Watu, \\
& Yayasan Pusaka, dsb \\
\hline
\end{tabular}

2. Pertemuan Kelompok Masyarakat secara Partisipatif

Penggalian persepsi dan pemahaman masyarakat lokal dirancang melalui sebuah kegiatan pertemuan kelompok secara partisipatif. Pertama-tama dilakukan identifikasi anggota masyarakat di dusun Kekep yang mewakili kelompok-kelompok stakeholder sebagaimana disebutkan di atas. Masing-masing kelompok masyarakat dari unsur petani hutan (LMDH), petani luar kawasan, peternak, pengusaha, tokoh masyarakat, pamong desa/ dusun, perempuan dan pemuda/ karang taruna diundang untuk menghadiri pertemuan yang dilaksanakan selama 2 hari.

Tahapan pertemuan dengan masyarakat adalah sebagai berikut:

- Penetapan tujuan/sasaran pertemuan: mengidentifikasi potensi dan masalah untuk menyusun rancangan program konservasi yang akan dijadikan dokumen dusun/desa dan diusulkan melalui RPJM Desa atau MUSRENBANG

- Diagnosa: proses diagnosa dilakukan melalui dua langkah kegiatan memakai alat-alat PRA : (a) kegiatan dalam ruangan yaitu focus group discussion (FGD), penelusuran sejarah dusun/desa, analisis kalender musim, analisis time-line dan trend line, analisis ranking, dan analisis kelembagaan (diagram Venn), serta (b) kegiatan lapangan penelusuran transek dan pemetaan partisipatif.

- Penyusunan RTL (rencana tindak lanjut): Langkah ketiga ini sebenarnya tidak menjadi agenda survei LEK, tetapi antara peneliti dan masyarakat desa telah bersepakat agar pertemuan ini menghasilkan sesuatu yang bermanfaat bagi desa/ dusun. Hasil kesepakatan itu adalah bahwa masyarakat akan difasilitasi untuk menyusun rencana tindak lanjut kegiatan ini sehingga dapat menjadi sebuah usulan program partisipatif yang akan dibahas dalam musyawarah pembangunan tingkat desa (Musrenbangdes) dan dimasukkan dalam Rencana Pembangunan Jangka Menengah Desa (RPJMD). Selanjutnya, RPJMD diangkat oleh Desa ke 
musyawarah pembangunan Kecamatan untuk diusulkan menjadi program pembangunan di tingkat Kota Batu pada tahun yang akan datang.

- Refleksi: oleh peserta pertemuan

Jumlah warga setempat yang hadir dalam beberapa kegiatan dalam pertemuan kelompok masyarakat Dusun Kekep antara sebanyak 28 - 32 orang ditambah para peneliti RHA yang berperan sebagai fasilitator, serta beberapa orang tamu sebagai pengamat seperti pamong desa, LSM, dsb.

3. Artikulasi Pengetahuan Masyarakat

Penelusuran transek dan pemetaan partisipatif potensi DAS mikro Talun dengan warga masyarakat Dusun Kekep dilakukan selama satu hari penuh. Peserta dibagi menjadi 4 (empat) kelompok, masing-masing dipandu oleh satu orang fasilitator. Penelusuran dimulai dari bagian puncak DAS Mikro Talun, yakni pada titik terdekat dengan kawasan Taman Hutan Raya R. Soerjo. Setiap kelompok melewati jalur-jalur yang sudah disepakati dan jalur kelompok yang satu berbeda dengan jalur kelompok yang lain.

Dalam penelusuran ini pertama-tama dilakukan pengamatan (observasi) kondisi lahan aktual di beberapa lokasi yang sudah direncanakan menurut toposekuen. Hasil observasi berupa fakta-fakta di lapangan yang dituangkan dalam gambar transek. Kegiatan kedua adalah mencari permasalahan di wilayah sekitar lokasi (diperluas radiusnya), mendiskusikan kemungkinan penyebab dan mengusulkan alternatif solusinya. Hasilnya digambarkan dalam sketsa peta yang menunjukkan lokasi yang bermasalah, macam permasalahan dan solusi.

Proses ini berjalan agak lambat, karena terjadi interaksi yang sangat dinamis diantara peserta. Kesan pertama yang diungkapkan oleh peserta adalah bahwa inilah kesempatan pertama kali mereka mengamati dan memperhatikan sungguh-sungguh dan detil kondisi lingkungan sekitar mereka. Biasanya mereka hanya sekedar lewat dan melihat sambil lalu sehingga menjadi pemandangan yang sangat biasa dan tidak berkesan. Melalui pengamatan dan pemetaan ini terjadi diskusi diantara para peserta anggota kelompok tentang isu-isu aktual, potensi sumberdaya alam, pengelolaan, dan permasalahan yang dihadapi terkait dengan hidrologi DAS menurut pandangan dan pengetahuan peserta.

Hasil gambar transek dan peta sketsa serta catatan yang dibuat setiap kelompok menjadi bahan diskusi dalam pertemuan lanjutan yang dilaksanakan pada malam hari setelah kegiatan lapangan di siang harinya. Hasil yang diperoleh setiap kelompok bisa serupa dan saling menguatkan, tetapi bisa saling bertentangan satu dengan yang lain. 
Hasil transek dan peta sketsa keempat kelompok yang cukup beragam ini kemudian disatukan menjadi sebuah potret kondisi DAS Mikro Talun.

4. Pengolahan Data dan Evaluasi

Dalam pertemuan pleno seluruh peserta, setiap kelompok menyampaikan hasil penelusuran dan pemetaan partisipatif masing-masing kelompok untuk ditanggapi dan dibahas bersama. Pembahasan berlangsung sangat dinamis karena setiap peserta memiliki pengalaman yang sama dalam proses ini, sehingga pada ahirnya dicapai kesepakatan dan diperoleh kesimpulan yang dituangkan dalam hasil pertemuan. Hasil ini disampaikan dalam laporan tentang kondisi aktual dan identifikasi potensi dan permasalahan di DAS Mikro Talun. Laporan pertemuan ini merupakan kompilasi data tentang pengetahuan dan pemahaman masyarakat terhadap berbagai aspek yang terkait dengan fungsi hidrologi DAS Mikro Talun.

\subsection{Kondisi Lokasi Penelitian}

\subsubsection{Kondisi Umum}

Penelitian ini dilaksanakan di Dusun Kekep, Desa Tulungrejo Kecamatan Bumiaji Kota Batu. Lokasi dusun ini berada lebih-kurang di tengah wilayah Kota Batu. Bagian hulu dusun merupakan kawasan hutan Perhutani dan bagian hilirnya merupakan kawasan pertanian hortikultura yang sangat intensif dan pemukiman yang sangat padat.

Dusun ini terletak dalam wilayah sebuah Sub-DAS kecil atau DAS Mikro bagian dari DAS Sumber Brantas, yang dinamai DAS Mikro Talun karena di hulu dusun ini terdapat sebuah tempat wisata air terjun Coban Talun. Kawasan wisata ini terletak ditengah-tengah hutan pinus Perhutani. Di kawasan wisata ini terdapat tempat untuk berkemah (camping ground) di antara pohon-pohon pinus yang sudah cukup tua.

DAS mikro ini luasnya lebih-kurang 200ha, terletak pada ketinggian antara 1,200 sampai 1,500m di atas permukaan laut. Kondisi biofisik DAS mikro ini cukup seragam karena hampir seluruhnya merupakan perbukitan vulkanik yang curam sampai terjal dan tertoreh. Tanah berkembang dari abu vulkanik yang sangat dalam dan umumnya subur.

Sekitar 90\% dari luasan DAS mikro ini merupakan kawasan Perhutani, sisanya adalah kawasan Tahura di bagian hulu dan kawasan milik masyarakat di bagian hilir. DAS mikro ini bermuara pada Kali Brantas disebelah selatan Dusun Kekep, Tulungrejo. Sekitar 66\% dari DAS mikro ini merupakan lahan terbuka (gundul), sementara $31 \%$ berupa semak-semak dan hanya 3\% merupakan hutan pinus bercampur semak (Gambar 3.2.). Hampir dua pertiga kawasan memiliki lereng curam (lebih dari $40 \%$ ) dan sepertiga lainnya sangat curam $(>60 \%)$ 
dengan panjang lereng antara $150 \mathrm{~m}$ sampai $700 \mathrm{~m}$. Setengah dari kawasan ini sudah diteras, tetapi hanya sebagian saja yang kondisinya cukup baik.

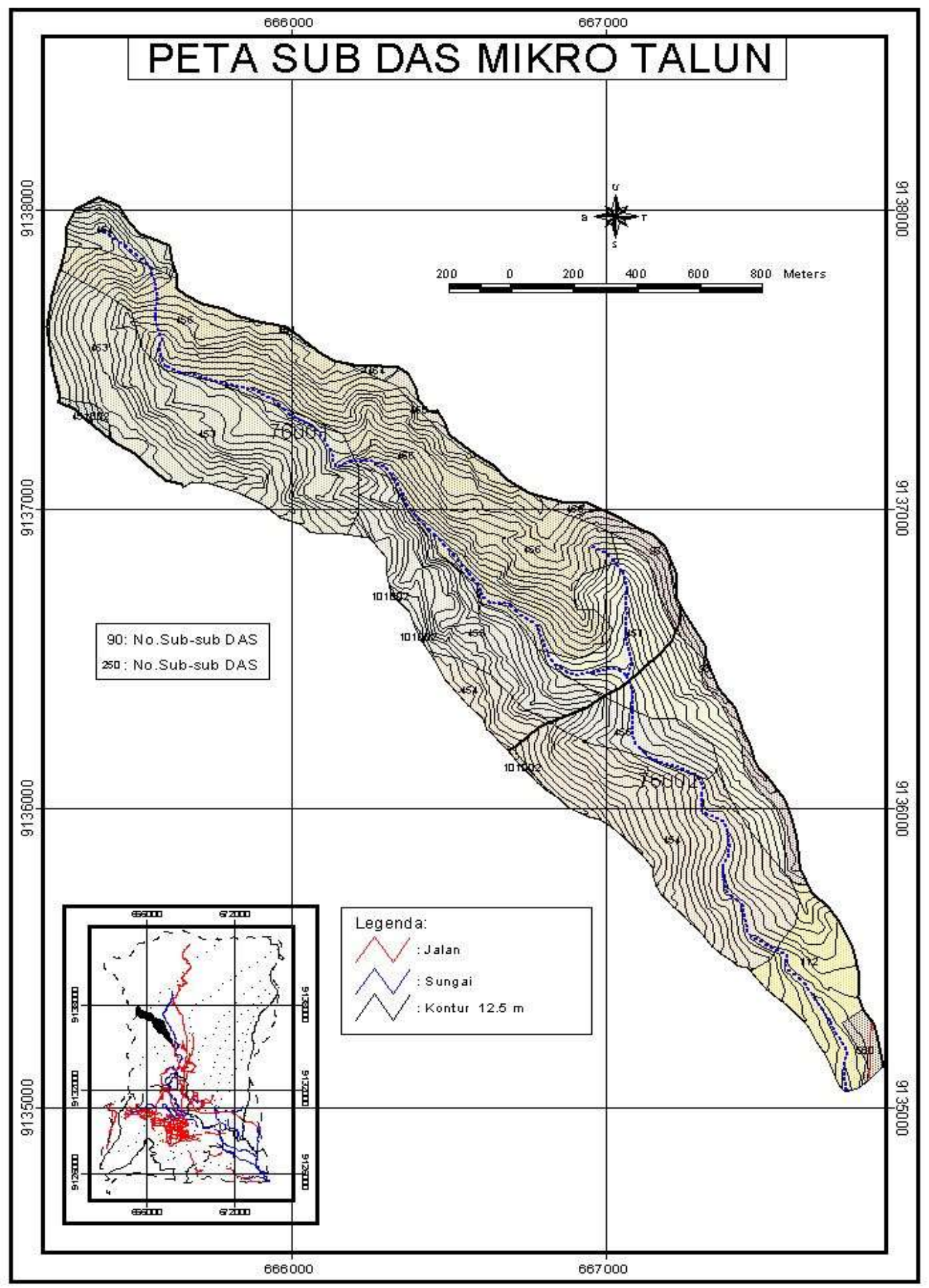

Gambar 3.1. Peta Sketsa DAS Mikro Talun, sebagai bagian dari DAS Sumber Brantas 

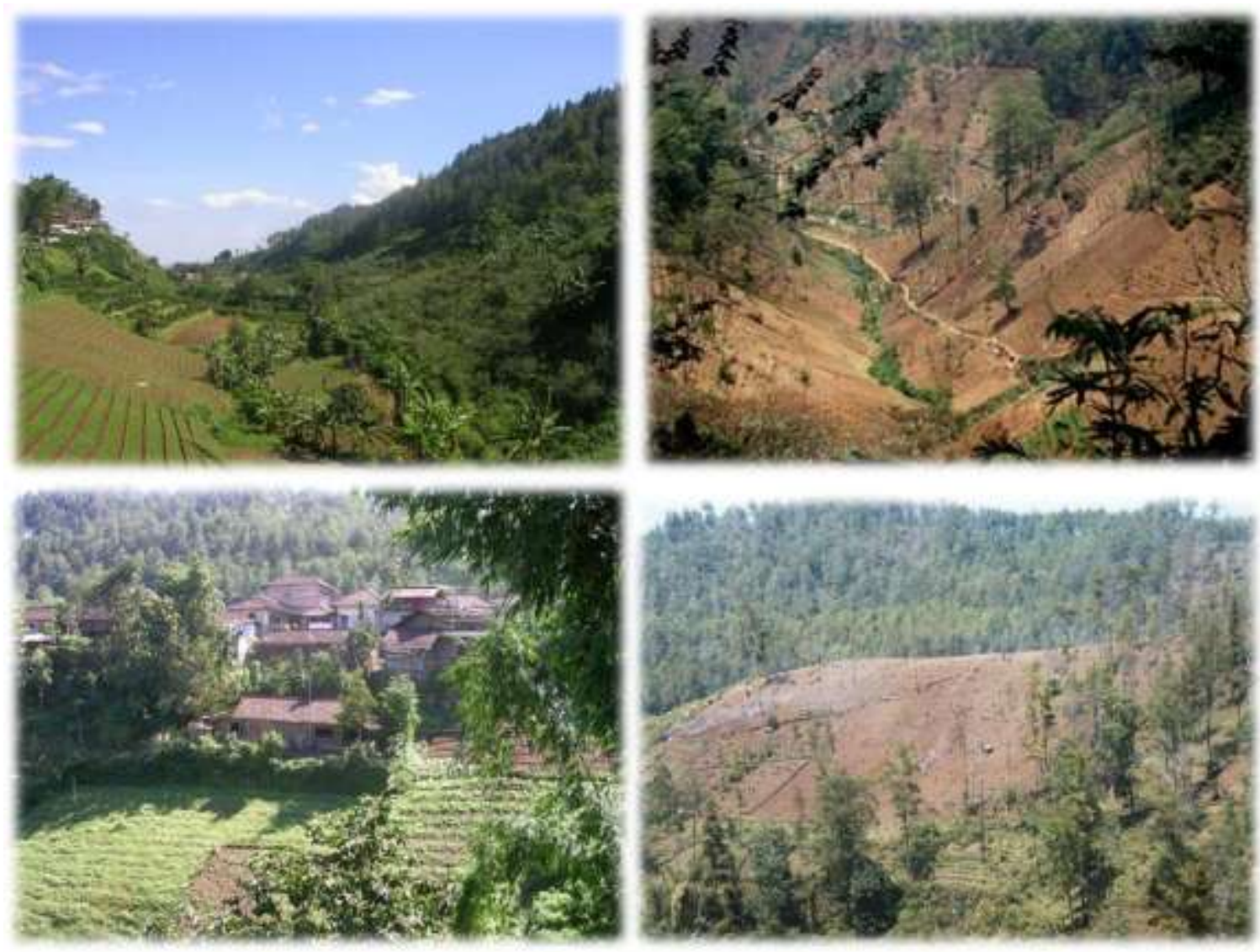

Gambar 3.2.Gambaran Kondisi Umum Dusun Kekep: Kondisi DAS Mikro disekitar pemukiman (foto kiri) dan Kondisi di bagian hulu yang merupakan wilayah Perhutani (foto kanan atas)

Beberapa kejadian atau bencana yang pernah menimpa dusun ini disebutkan antara lain terjadinya banjir bandang pada tahun 2000 sehingga menghancurkan dan menghanyutkan bendungan air yang sudah dibangun sejak jaman kolonial Belanda. Tahun-tahun berikutnya juga selalu terjadi banjir besar setiap musim penghujan walaupun dampaknya tidak separah tahun 2000 .

Di hulu dusun ini terdapat beberapa sumber atau mata air yang menjadi sumber air bersih bagi warga dusun Kekep maupun desa-desa di hilirnya. Namun sejak tahun 2000an, beberapa sumber semakin mengecil debitnya dan bahkan ada beberapa mata air yang mati.

Pada tahun 2007 terjadi musibah dengan tumbangnya beberapa batang pohon pinus tua yang berada di kawasan wisata Coban Talun akibat adanya angin kencang (angin puyuh). Dan salah satu pohon yang tumbang itu menimpa siswa-siswi sekolah yang sedang berkemah disana mengakibatkan seorang meninggal dunia. Akibatnya, beberapa pohon tua yang ada di kawasan itu ditebang untuk menghindari kejadian serupa, karena adanya angin puting beliung yang semakin sering terjadi pada akhir-akhir ini. 


\subsubsection{Sejarah Dusun Kekep}

Tidak diketahui secara pasti kapan dusun ini terbentuk namun beberapa orang sudah bertempat tinggal dan bermukim di lokasi ini sejak awal abad ke-20. Dari ingatan beberapa orang mengatakan bahwa pada tahun 1958 jumlah keluarga yang bermukim di dusun ini masih sekitar belasan keluarga. Pada saat itu dusun ini hanya dapat dicapai melalui jalan setapak yang menghubungkan dengan kawasan pemukiman lain.

Hampir semua penduduk adalah petani yang mengerjakan lahan di sekitar pemukiman dengan menanam padi dan ketela pohon. Selain tanaman semusim, disekitar pemukiman juga ditanami dengan beraneka tanaman tahunan, misalnya anggrung, dadap, dsb. Lahan pertanian mereka berbatasan langsung dengan kawasan hutan, tetapi mereka tidak berani masuk ke dalah hutan karena menurut meraka ada larangan masuk ke hutan dan menebang pohon di hutan.

Sekitar tahun 1963, masyarakat mulai menanam sayur-sayuran dan mulai ada yang menanam di kawasan hutan atas seijin pihak Jawatan Kehutanan (sekarang Perhutani). Pada tahun 1968 dilakukan pelebaran jalan setapak menjadi jalan kampung yang bisa dilewati kendaraan roda 4, walaupun masih berupa jalan tanah yang sulit dilewati apabila hujan. Jumlah luasan tanaman sayuran semakin bertambah, dan pada tahun 1970 di kawasan hutan dijumpai tanaman sayuran yang juga semakin luas. Pada tahun 1998 mulai terjadi penebangan hutan di mana-mana termasuk di kawasan Kota Batu, sehingga pada tahun 2001 tanaman kayu-kayuan di hutan sudah habis ditebang.

Menurut pengamatan beberapa orang anggota masyarakat Dusun Kekep, kondisi air sungai mengalami perubahan dibandingkan sepuluh tahun yang lalu (sebelum 1998). Perubahan yang diamati adalah penurunan debit pada musim kemarau bahkan seringkali sangat kecil, dan pada musim penghujan sering terjadi banjir yang lebih besar dibanding waktu lampau.

Sumber air yang terdapat di wilayah dusun ini juga digunakan oleh desa-desa lainnya di bagian hilir. Tidak ada insentif atau kompensasi dalam penggunaan air tersebut kepada desa Tulungrejo. Pada saat ini terdapat 57 titik mata air yang tersebar di seluruh kawasan desa Tulungrejo. Pengambilan air dari sumber air atau dari sungai sebenarnya harus mendapatkan ijin dari Dinas Pengairan dan Bina Marga Kota Batu (dulu Dinas Sumberdaya Air dan Enerji). Namun fakta di lapangan menunjukkan bahwa tidak ada pihak yang merasa memberikan ijin pengambilan air tersebut.

Pada saat reformasi dilakukan penebangan hutan secara besar-besaran. Setelah reformasi terjadi bencana alam angin puyuh, banyak pohon tumbang. Pinus masuk ke dusun Kekep sekitar 30 tahun yang lalu, sedangkan di Selekta sudah hampir 40 tahun. Pinus masuk bersamaan dengan tanaman pertanian (ketela rambat dan jagung). Program pemerintah masuk 
dusun Kekep pada tahun 2004 setelah terjadi banjir bandang besar pada musim hujan tahun sebelumnya.

\subsection{Kondisi Lahan di Kawasan DAS Mikro Kekep}

Penelusuran transek DAS Mikro Talun dilaksanakan oleh kelompok masyarakat Dusun Kekep untuk melihat apa yang sebenarnya terjadi di lapangan. Sebelumnya tidak pernah dilakukan penelusuran secara bersama-sama, tetapi ada beberapa orang yang pernah menelusuri transek ini secara individual dan tidak khusus mengamati kondisi DAS mikro. Hasil berikut ini merupakan rangkuman dari proses pembuatan gambar transek secara partisipatif yang dilakukan oleh warga masyarakat Dusun Kekap.

Hasil pengamatan bersama terutama dilakukan terhadap penggunaan lahan (land use) yang dituangkan dalam uraian berikut ini. Ternyata apa yang diamati oleh masyarakat Dusun Kekep di DAS Mikro Talun hampir sama dengan yang terjadi di kawasan lain DAS Sumber Brantas (Bab 2). Hasil pengamatan landuse di DAS Mikro Talun dapat dikelompokkan menjadi beberapa macam dengan ciri-cirinya yang terkait dengan fungsi lahan untuk konservasi dan hidrologi:

\subsubsection{Hutan Alam (primer atau sekunder)}

Hutan alam dijumpai di bagian paling hulu DAS mikro Talun, dicirikan dengan kerapatan dan keragaman jenis (species) pohon dan tajuk. Permukaan tanah tertutup rapat oleh tumbuhan bawah dan seresah, serta memiliki relief mikro dan makro yang alami. Hutan alam ini merupakan bagian dari wilayah Taman Hutan Raya R. Soerjo. Dalam penelusuran ditemukan tanda-tanda bekas longsor dengan skala kecil yang mungkin terjadi beberapa tahun lalu.

\subsubsection{Hutan Tanaman (Hutan Produksi)}

Bagian ini dikenal oleh masyarakat sebagai kawasan hutan produksi yang dikelola oleh Perum Perhutani KPH Malang. Kawasan ini seharusnya ditanami dengan jenis pohon pinus (Pinus mercusii) secara monokultur mengikuti aturan atau ketentuan Perhutani (misalnya jarak tanam, cara pengelolaan, dsb). Dilihat dari kondisi penutupan lahan, masyarakat bisa mengelompokkan kawasan hutan ini menjadi beberapa macam:

1. Lahan Gundul: yaitu lahan-lahan bekas tebangan yang belum ditanami oleh Perhutani, sehingga ditumbuhi oleh rumput dan semak-semak. Sebagian besar lahan semacam ini sudah dibagikan kepada petani pesanggem untuk ditanami tanaman semusim. Pada musim kemarau kelihatan tertutup semak, tetapi menjelang musim hujan petani biasanya sudah membersihkan semak tersebut sehingga kelihatan terbuka atau gundul. 
2. Lahan dengan tanaman pinus muda (umur kurang dari 4 tahun): lahan bekas tebangan yang sedang atau sudah ditanami pinus. Tanaman pinus masih kecil sehingga belum tampak karena tertutup oleh rapatnya tanaman semusim yang ditanam disela-sela tegakan. Sesuai aturan, petani sebenarnya hanya bisa menanam tanaman semusim sampai pinus berumur tiga atau empat tahun.

3. Lahan dengan tanaman pinus berumur 4-8 tahun: Secara teoritis tanaman pinus yang sudah berumur lebih dari 4 tahun telah memiliki tajuk tanaman yang rapat sehingga tidak memungkinkan lagi ada tanaman semusim disela-selanya. Namun kenyataan di lapangan menunjukkan bahwa walaupun pinus sudah berumur 4-8 tahun ternyata dibawahnya masih ditanami tanaman semusim. Salah satu upaya yang dilakukan petani hutan adalah melakukan pemangkasan daun pinus sehingga mengurangi kerimbunan tajuknya.

4. Lahan dengan tanaman pinus tua (umur lebih dari 8 tahun): Pohon pinus yang sudah berumur lebih dari 8-10 tahun memiliki sistem perakaran dan tajuk yang sudah sangat rapat, sehingga mempengaruhi komposisi seresah dan relief bawah tegakan.

Demikian pula tumbuhan bawah sudah mulai tumbuh rapat sementara tanaman semusim (tanaman pangan) sudah hampir tidak ada lagi, yang ditanam umumnya rumput gajah. Namun kenyataannya, di kawasan ini dijumpai hutan pinus yang sudah berumur lebih dari 8 tahun tetapi kerapatan pohonnya (populasi) jarang sehingga di bawah tegakan masih bisa diusahakan tanaman semusim.

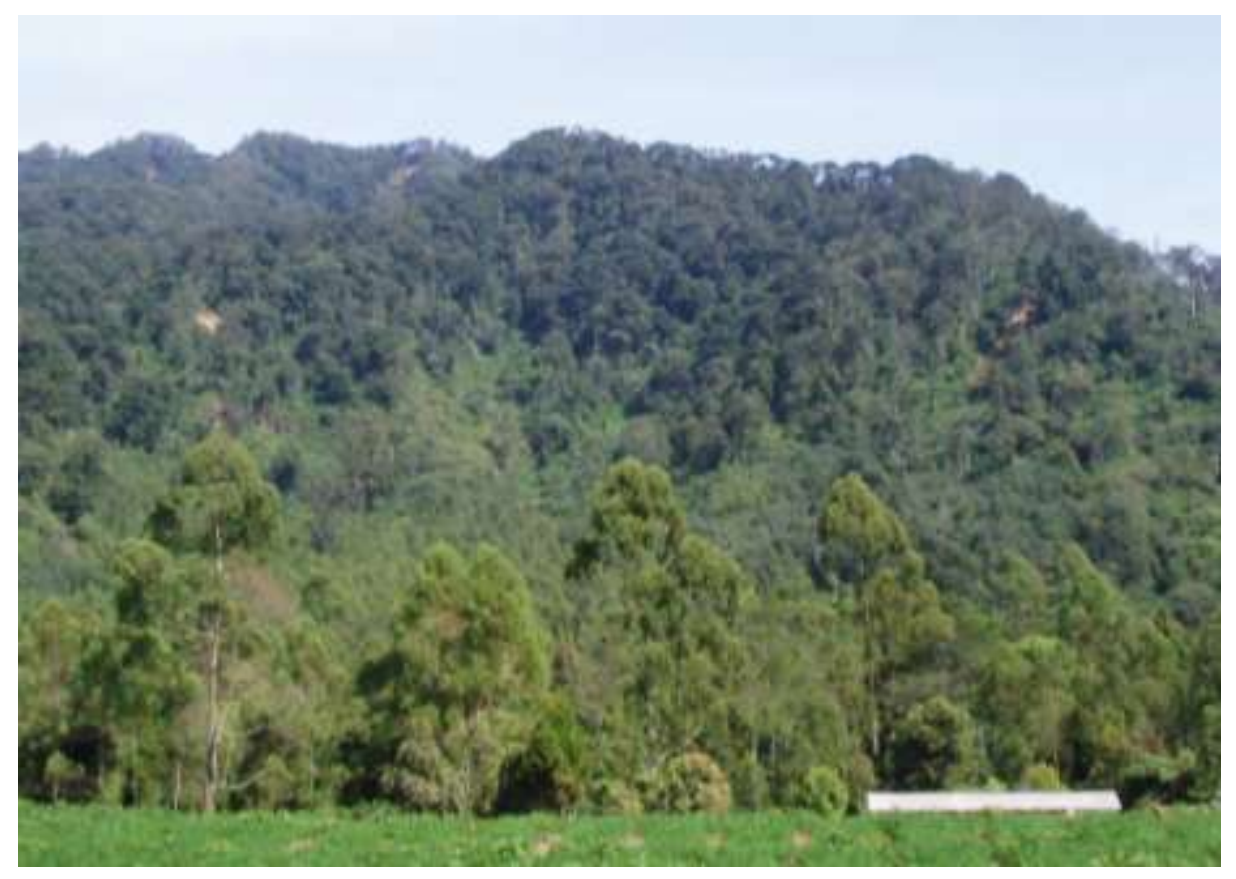

Gambar 3.3. Kondisi Hutan Alam di bagian hulu DAS Mikro Talun termasuk wilayah Taman Hutan Raya Raden Soerjo, luasnya hanya sekitar $5 \%$ dari luas DAS mikro ini. 

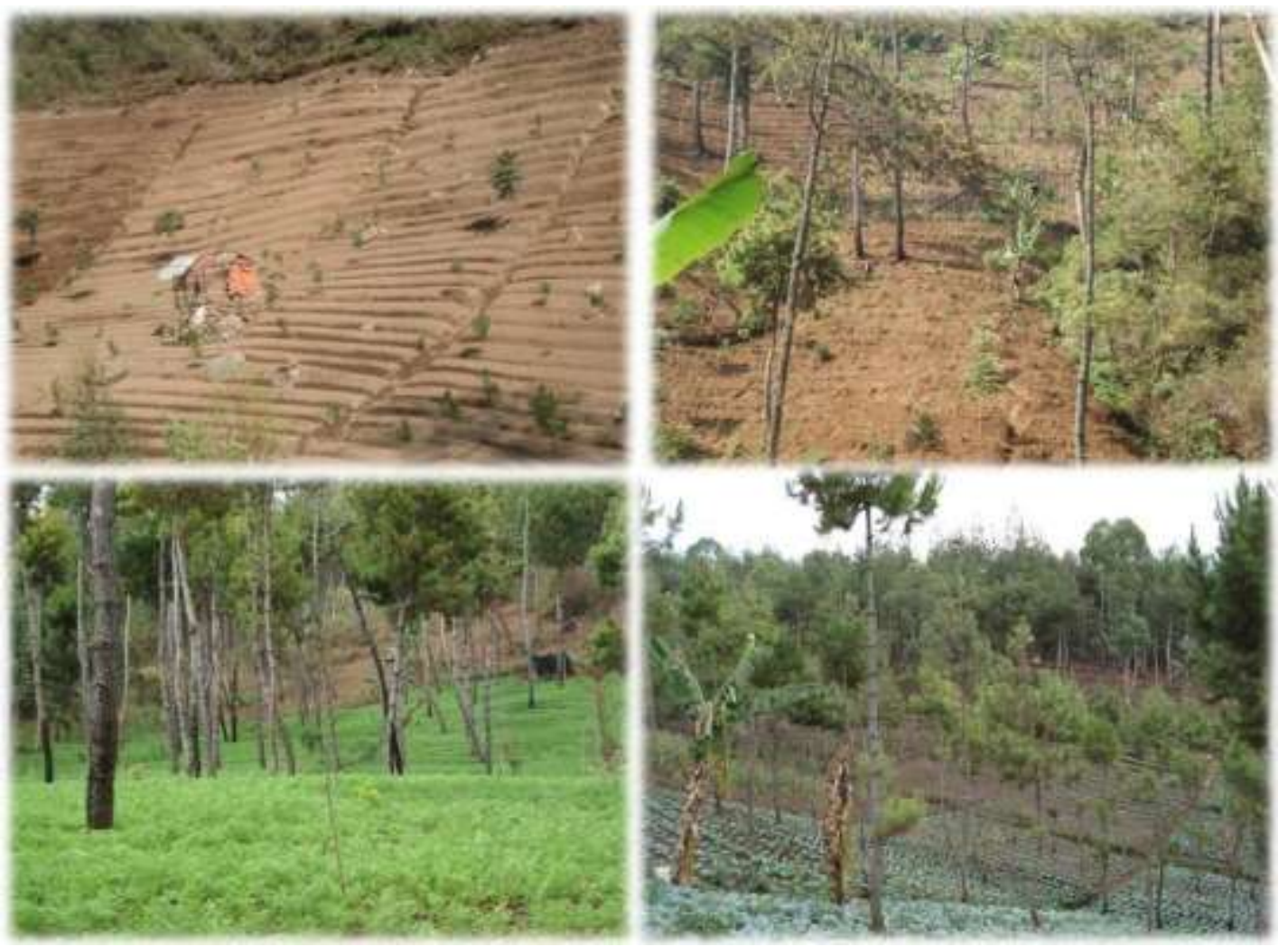

Gambar 3.4. "Hutan Pinus" dengan macam-macam umur pinus dan pengelolaan bawah tegakan pinus

\subsubsection{Lahan pertanian dan kebun buah-buahan}

Bagian hilir DAS mikro Talun di sekitar pemukiman umumnya merupakan lahan milik masyarakat. Lahan disini sudah dikelola masyarakat untuk usaha pertanian secara intensif. Lahan bisa dibagi menjadi dua kelompok, yaitu lahan tadah hujan dan lahan irigasi. Lahan irigasi dijumpai di bagian lembah, permukaan tanah diratakan, dibuat datar dan teras bertingkat-tingkat sehingga bisa diairi dengan cara penggenangan. Lahan ini mungkin pernah ditanami padi tetapi sekarang tidak lagi. Sementara itu, lahan tadah hujan terdapat di bagian lereng, sudah diteras atau hanya digulud saja tetapi permukaan tanah tidak selalu dibuat datar. Mendapatkan air dari hujan atau jika diairi dengan menggunakan gembor atau sprinkler sederhana. Kedua kelompok lahan ini ditanami dengan dua kelompok tanaman yaitu tanaman buah-buahan (apel dan jeruk) dan tanaman semusim (tanaman pangan, sayur, atau bunga).

Persiapan tanah meliputi pengolahan tanah, pembuatan bedengan atau guludan, pembuatan teras bangku atau teras sederhana dan pemberian bahan organik. Pemeliharaan sangat intensif meliputi pemupukan, pengendalian hama dan penyakit, drainasi (untuk musim hujan) dan bahkan pemberian air irigasi pada musim kemarau dengan memakai sprinkler atau penyemprotan dengan pompa air. 


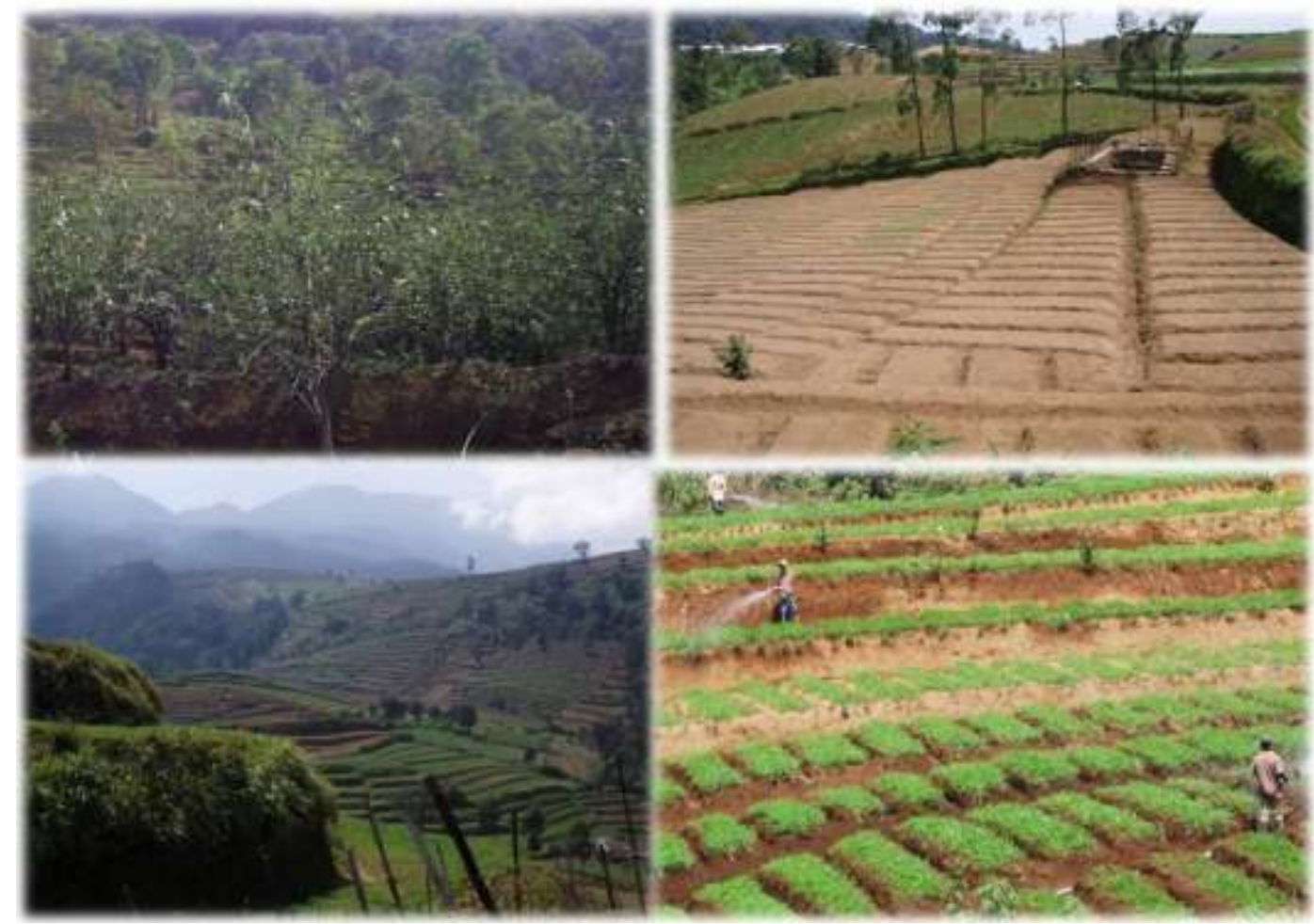

Gambar 3.5. Kawasan budidaya yang digunakan untuk pertanian tanaman buah-buahan, sayur-sayuran dan bunga-bungaan.

\subsubsection{Kawasan Pemukiman atau Bangunan}

Penggunaan lahan untuk pemukiman atau bangunan merupakan salah satu bentuk penggunaan lahan yang menutup kawasan resapan dengan bangunan berupa gedung, jalan atau yang lainnya. Di bagian hulu DAS Sumber Brantas (tetapi di luar wilayah DAS mikro Talun) terdapat perusahaan jamur dengan bangunan yang sangat banyak (Gambar 3.6.).

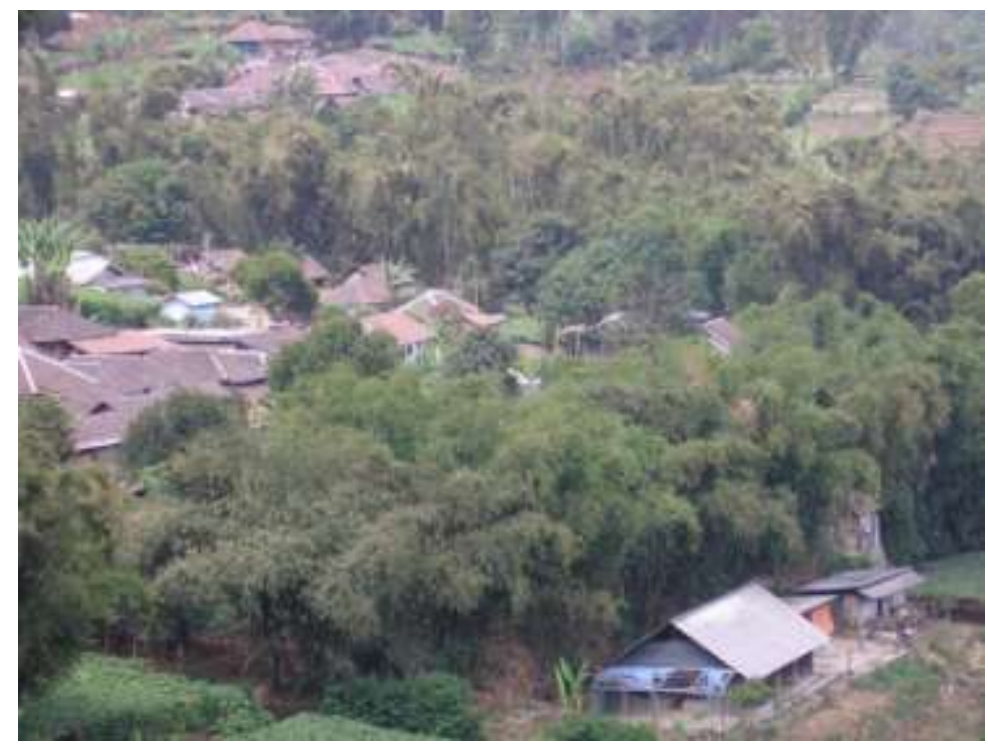

Gambar 3.6. Kawasan Pemukiman dan/atau tertutup oleh Bangunan 


\subsection{Kondisi Aktual DAS Mikro Talun}

Dalam beberapa pertemuan dengan masyarakat dan pejabat birokasi Kota Batu selalu dikemukakan bahwa telah terjadi kerusakan hutan akibat "penebangan liar" yang mengakibatkan banyak lahan yang gundul kemudian ditanami sayuran, selanjutnya mengakibatkan kekeringan dimusim kemarau dan banjir dimusim penghujan. Pernyataan atau statement seperti itu sudah sering terdengar di berbagai kesempatan dan dilontarkan oleh berbagai pihak. Namun, jika ditanyakan lebih detil lagi di mana lahan yang kritis, berapa luasnya, bagaimana kondisinya, dst ternyata tidak banyak yang bisa memberi penjelasan secara tepat dan akurat.

Oleh sebab itu ketika rencana penelusuran DAS Mikro Talun dilontarkan kepada peserta pertemuan di Dusun Kekep, mereka sangat antusias untuk melakukannya. Menurut pengakuan peserta ini adalah kegiatan pertama kali yang dilakukan oleh warga masyarakat setempat secara bersama-sama. Penelusuran DAS Mikro Talun bersama masyarakat ditujukan untuk mengetahui kondisi aktual kawasan ini dan isu-isu terkait dengan kuantitas dan kualitas hasil air. Proses penelusuran dikemas dalam kegiatan pembuatan transek DAS Mikro Talun dan Pemetaan Partisipatif untuk menginventarisasi potensi, masalah dan solusi terkait dengan aspek hidrologi dalam pengelolaan DAS.

Beberapa fakta yang dianggap penting oleh peserta penelusuran terkait dengan isu-isu hidrologi DAS Mikro Talun adalah:

\section{- Luas Hutan}

Keberadaan hutan alam di DAS Mikro Talun ternyata hanya sebagian kecil dari luasan DAS Mikro (informasi: taksiran dari foto udara hanya 5\%). Setelah tahu kondisi ini masyarakat bertekad ikut serta melindungi hutan dari upaya pencurian kayu khususnya dari kawasan Tahura R. Soerjo.

- Mata Air

Beberapa titik mata air yang dulu pernah ada di kawasan hutan produksi ternyata sekarang sudah tidak mengeluarkan air lagi atau mati. Beberapa orang berusaha menunjukkan lokasi bekas mata air tersebut. Hal ini dihubungkan dengan kondisi penutupan lahan di sekitarnya, di mana sudah tidak ada pohon-pohon besar yang bisa menahan air, digantikan oleh tanaman semusim.

- Pengambilan dan Penggunaan Air

Pada saat penelusuran sepanjang sungai, ditemukan adanya upaya menyedot air dengan pompa mesin di beberapa titik sungai dan sumber air. Pengambilan air ini digunakan untuk irigasi lahan yang terletak di atas sungai tersebut atau bahkan ada 
yang beberapa kilometer jauhnya. Masyarakat mengeluhkan pengambilan air yang mengakibatkan debit sungai semakin mengecil pada musim kemarau. Timbul dugaan bahwa ada oknum dari instansi yang berwenang memberi ijin secara tidak semestinya (ilegal).

\section{- Debit Sungai}

Debit air sungai pada saat penelusuran di bulan Agustus (pertengahan musim kemarau) sangat kecil dibandingkan sekitar sepuluh tahun yang lalu. Debit sungai yang kecil ini dikaitkan dengan kondisi lahan yang sudah gundul dan banyaknya pengambilan air dengan cara disedot dengan mesin pompa di hulu bahkan di mata air untuk irigasi tanaman sayuran milik petani kaya dan untuk industri dan perusahaan besar.

- Tutupan Lahan: Hutan

Kondisi hutan produksi (hutan tanaman) di kawasan ini sebagian besar tidak ada tegakannya, jika ada umumnya masih kecil sehingga dari jauh kelihatan gundul. Hanya sebagian kecil saja kawasan ini yang masih terdapat pohon pinus berusia lebih dari 20 tahun, tetapi populasinya sudah tidak rapat lagi. Hampir seluruh kawasan hutan produksi sudah dibagi habis oleh petani hutan (pesanggem) sebagai penggarap yang pada umumnya menanam tanaman pangan atau sayur-sayuran disela-sela tanaman pokok (tegakan).

\section{- Tutupan Lahan: Tanaman Semusim}

Pada saat penelusuran (akhir bulan Agustus), sebagian besar lahan sudah mulai dikerjakan oleh petani sebagai persiapan menanam jagung atau sayur yakni berupa pembersihan tanah dan pembuatan guludan. Masyarakat paham jika sewaktu-waktu terjadi hujan deras, maka sebagian lapisan tanah yang terbuka itu akan hanyut sebagai walet (erosi) yang mengakibatkan sungai menjadi keruh. Erosi atau kehilangan tanah ini menurut pendapat masyarakat bukan sebagai penyebab utama menurunnya produksi tanaman, melainkan diakibatkan oleh penggunaan pupuk kimia yang berlebihan sehingga tanah menjadi keras (krokos).

- Longsor

Di beberapa titik ditemukan tanah longsor atau bekas longsor, yang umumnya pada lereng sangat curam dan tidak ada atau sedikit pepohonan. Sebagian besar peserta penelusuran tidak menyangka jika dijumpai beberapa titik bekas longsor yang sudah lama ataupun longsor yang baru terjadi musim hujan sebelumnya. 
- Tutupan Lahan: Pemukiman dan Bangunan

Banyak bangunan baru berupa perumahan, hotel atau bangunan dari perusahaan industri/ pertanian/ peternakan yang menempati areal cukup luas di bagian hulu DAS Sumber Brantas tetapi di luar DAS Mikro Talun.

Pengamatan langsung terhadap sumberdaya lahan di lapangan yang disaksikan oleh beberapa orang warga dusun setempat membuat masyarakat menjadi lebih "terbuka" akan apa yang sebenarnya telah terjadi. Dua kejadian penting adalah (a) tumbuhnya kesadaran bahwa telah terjadi kesalahan yang mengakibatkan kerusakan alam, dan (b) tumbuhnya komitmen dan kebersamaan diantara masyarakat untuk membangun dan memperbaiki kerusakan alam yang terjadi. Hasil penelusuran dan pemetaan ditambah dengan analisis yang dilakukan dengan bantuan alat-alat PRA menjadi dokumen milik kelompok masyarakat Dusun Kekep yang kemudian dipakai dalam beberapa kegiatan seperti pembuatan rancangan pembangunan dusun, dan sebagai pegangan dalam negosiasi dengan beberapa pihak misalnya dengan Perum Perhutani, dan dinasdinas di Kota Batu.

\subsection{Pengetahuan Lokal Hidrologi dan Pengelolaan DAS}

Berdasarkan fakta yang ditemukan melalui penelusuran untuk membuat transek dan peta partisipatif, peserta mengembangkan permasalahan yang bisa dilihat di lapangan dengan pengetahuan dan pengalaman masing-masing. Berikut ini hasil pengembangan diskusi, berupa rangkuman permasalahan utama di DAS Mikro Talun baik yang sudah terjadi maupun yang berpotensi untuk menjadi masalah dikemudian hari.

1. Banjir

Tipe banjir yang terjadi di DAS Mikro Talun adalah banjir bandang, berupa aliran air yang sangat besar dan kuat datang secara tiba-tiba dan tidak berlangsung lama.

Menurut warga setempat, adalah normal jika debit sungai bertambah besar pada musim hujan, karena ada bagian air hujan yang masuk ke sungai. Istilah "banjir" dimaksudkan sebagai peningkatan debit sungai sehingga permukaan air sungai naik beberapa meter dibanding biasanya (kondisi normal), namun tidak sampai meluap ke luar badan sungai. Pada saat "banjir" tersebut, air sungai lebih keruh dari biasanya.

Beberapa tahun yang lalu, tepatnya pada tahun 2000 terjadi banjir bandang tidak seperti yang terjadi sebelumnya. Air sungai meluap dan merusak lahan pertanian di kanan-kiri sungai, membawa batang dan ranting kayu kecil sampai besar dan batubatu besar serta berwarna sangat keruh. Aliran air ini merusak tebing sungai dan 
menghancurkan beberapa bangunan sungai seperti cek-dam dan jembatan. Hal ini terus terjadi setiap tahun dan puncaknya terjadi banjir besar pada tahun 2004 .

- Banjir besar (banjir bandang) disebabkan oleh penebangan atau penggundulan hutan terutama di kawasan Perhutani.

- Air hujan yang jatuh tidak ada lagi yang mampu menahan, sehingga langsung masuk ke sungai sambil mengangkut sisa-sisa tebangan kayu, terjadilah banjir yang besar.

- Banjir bandang bisa dicegah apabila lahan yang sudah gundul dihutankan kembali (reforestasi).

- Jenis tanaman yang bisa dipakai untuk reforestasi adalah pohon-pohon hutan (mahoni, suren, pinus, akasia, dsb).

- Tidak semua jenis tanaman tahunan atau pohon bisa mencegah banjir, Selain pohon hutan pohon buah-buahan yang batangnya besar seperti durian, nangka, dsb yang bisa mencegah banjir.

2. Erosi

Kejadian erosi dapat dilihat dari dua sudut, pertama dari aspek kehilangan tanah di lahan dan kedua dari aspek pengendapan material tanah yang terangkut oleh aliran air (sedimen). Masyarakat di Dusun Kekep tidak melihat adanya masalah erosi yang terkait dengan sedimentasi, karena di sepanjang DAS Mikro Talun tidak dijumpai adanya pengendapan lumpur kecuali batu-batuan. Terkait dengan erosi, yang dapat dirasakan oleh masyarakat adalah kekeruhan air sungai. Sebenarnya masyarakat tidak terganggu oleh keadaan ini karena mereka tidak berhubungan dengan air yang keruh tersebut. Namun, ternyata pada saat-saat itu air minum (yang diperoleh langsung dari sumber air atau melalui PDAM Desa atau HIPPAM) juga menjadi keruh. Kekeruhan air untuk kebutuhan domestik yang inilah yang membuat masyarakat merasa terganggu dengan adanya erosi.

Sementara itu, aspek kehilangan tanah tidak terlalu dirisaukan atau bahkan tidak dihiraukan sama sekali oleh masyarakat. Masyarakat tidak merasa rugi/dirugikan oleh adanya erosi, karena tidak ada hal-hal yang langsung dirasakan ketika erosi terjadi. Sebenarnya, melalui analisis kecenderungan (trend analysis) yang telah dibuat oleh masyarakat ketika pertemuan survei LEK terungkap bahwa memang telah terjadi perubahan secara gradual yang terjadi pada tanah/lahan di DAS Mikro Talun akibat erosi. Perubahan yang bersifat negatif dapat dikenali melalui beberapa indikator yang disebutkan oleh masyarakat seperti (a) kebutuhan pupuk yang semakin meningkat, (b) 
produksi yang terus menurun (misalnya apel), (c) adanya tanaman yang dulu bisa tumbuh baik tetapi sekarang tidak (misalnya kentang).

- Erosi hanya terjadi pada lahan miring yang tidak diteras.

- Besarnya erosi tidak dipengaruhi oleh jenis tanaman semusim yang ditanam, tetapi oleh ada atau tidaknya teras yang baik.

- Erosi dapat dikurangi dengan membuat teras-teras.

- Rumpun bambu di kanan dan kiri sungai (kakisu) dapat menghambat tanah yang tererosi sehingga tidak semua masuk ke sungai.

3. Longsor

Ada beberapa macam longsor menurut persepsi masyarakat berdasarkan lokasi kejadiannya: longsor di kawasan pemukiman, longsor (tebing) jalan, longsor (tebing) sungai, longsor di kawasan budidaya pertanian dan longsor di kawasan hutan. Masyarakat menganggap kejadian longsor suatu peristiwa penting apabila kejadian itu mengakibatkan korban jiwa atau setidak-tidaknya merusak bangunan dan harta benda. Dari penelusuran sejarah (time-line), di dusun Kekep belum pernah terjadi longsor yang seperti dibayangkan oleh masyarakat, sehingga masyarakat selalu mengatakan tidak pernah ada kejadian longsor di dusun mereka.

Namun setelah melakukan penelusuran dan pemetaan partisipatif bersama-sama, akhirnya diketahui ternyata bahwa banyak kejadian longsor di sekitar lokasi dusun mereka. Karena biasanya longsor itu berskala kecil (dengan volume longsoran antara $\left.1-10 \mathrm{~m}^{3}\right)$, dan menurut mereka tidak ada dampaknya, kejadian itu tidak diperhitungkan sebagai peristiwa longsor. Melalui pengamatan ini akhirnya disepakati pengertian baru atau definisi tentang longsor, sehingga menurut mereka kejadian longsor memang sering terjadi.

- Longsor dipahami oleh masyarakat setempat sebagai kejadian runtuhnya material tanah dari tebing yang curam dalam volume yang besar sehingga mengakibatkan kerusakan harta benda dan korban jiwa. Jika volume material tanah yang runtuh kecil $\left(1-10 \mathrm{~m}^{3}\right)$ dan tidak sampai merusak infrastruktur, harta benda dan bahkan korban jiwa, maka kejadian itu tidak dianggap sebagai longsor.

- Longsor disebabkan oleh hujan deras yang menggerus dan meruntuhkan material tanah pada tebing sangat curam. Kejadian longsor dihubungkan dengan air yang berlebihan, baik dari hujan maupun aliran deras (permukaan dan sungai).

- Sementara itu, kejadian hujan deras dan aliran air berhubungan dengan kerusakan hutan di bagian hulu desa. 
- Secara tidak langsung kejadian longsor di semua lokasi termasuk kawasan pemukiman dan lahan budidaya dipicu oleh penebangan pohon-pohon di hutan.

4. Pencemaran Air oleh Sampah/ Limbah

Bagian hulu DAS Mikro Talun merupakan kawasan yang tertutup karena tidak ada akses untuk memasukinya kecuali jalan setapak. Kegiatan manusia di bagian hulu kawasan ini sangat minim karena hanya para petani dan pencari rumput yang setiap hari keluar-masuk kawasan. Namun, DAS mikro Talun berbatasan dengan sebuah kawasan wisata air terjun Coban Talun, yang seringkali dipakai untuk kegiatan camping, menghasilkan sampah yang sangat banyak. Masyarakat belum melihat timbunan sampah tersebut sebagai masalah. Demikian pula ketika di pinggir-pinggir jalan ada timbunan sampah industri rumah tangga yang dibuang (mungkin) oleh pengusaha dari tempat (desa) lain, masyarakat belum menganggap hal itu sebagai masalah bagi mereka.

Pembuangan sampah organik di dekat mata air juga dianggap biasa, bukan sebagai masalah karena menurut mereka hal itu tidak mengganggu. Jika air menjadi tercemar (bau atau warna), mereka biasanya mencari alternatif mata air yang lain untuk sementara, karena biasanya "pencemaran" itu akan hilang lagi.

Pembuangan sampah domestik (rumah tangga), sampah pertanian dan kotoran ternak padat di kawasan pemukiman dilakukan di tempat sampah berupa lubang galian tanah atau ditumpuk saja, sementara untuk sampah cair bisa dibuang ke selokan yang akhirnya masuk sungai. Bau "busuk" dari sampah tidak dihiraukan, karena seringkali hanya bersifat sementara nantinya akan hilang juga. Toleransi antar tetangga terhadap masalah sampah sangat tinggi karena hampir semua warga melakukan tindakan yang sama terhadap sampah di dusun itu.

- Sungai berfungsi untuk membersihkan sampah dan limbah.

- Jika aliran sungai sangat deras (banjir), sungai dapat menghanyutkan sampahsampah yang ada di dusun sehingga dusun mereka menjadi bersih.

- Sampah pertanian biasanya cukup ditimbun di sekitar lahan dan akhirnya alan membusuk dan bisa menyuburkan tanah.

- Sisa-sisa panen atau limbah pertanian yang menyebabkan munculnya hama dan penyakit (tanaman), harus segera dibakar atau dihanyutkan ke sungai.

- Hujan, aliran permukaan, aliran selokan dan aliran sungai yang deras menjadi sarana untuk membersihkan sampah atau kotoran di dusun dan juga di lahan pertanian. 


\section{Ketersediaan Air}

Air Kali Brantas digunakan oleh masyarakat untuk berbagai keperluan sehari-hari, mulai dari kebutuhan domestik rumah-tangga (air minum, mandi-cuci), pertanian (irigasi dan ternak), dan industri dan lain-lainnya. Air yang dapat digunakan harus memenuhi kriteria tertentu, khususnya kualitas, kuantitas dan kontinyuitasnya.

Beberapa tahun terakhir ini masyarakat Kota Batu dan sekitarnya (bagian hilir) mulai mengeluhkan ketersediaan air yang tidak lagi sesuai dengan kebutuhannya. Beberapa permasalahan penyediaan air yang dikeluhkan masyarakat menyangkut kualitas air (misalnya sedimen dan pencemaran kimia) dan distribusi air pada musim kemarau dan musim hujan.

Masalah yang dinilai potensial terjadi di masa mendatang adalah perebutan air bersih untuk keperluan domestik dengan keperluan lain seperti irigasi dan industri di musim kemarau. Ketika menelusuri DAS Mikro Talun dijumpai pengambilan air langsung dari sungai dan mata air dengan memakai pompa untuk irigasi bagi tanaman sayuran yang diusahakan pada musim kemarau. Di balik fakta perebutan sumberdaya air yang mulai langka, terdapat dua isu penting menyangkut ketidak-adilan yang dikemukakan masyarakat terkait dengan gejala ini, yaitu:

a. Penggunaan mesin pompa untuk menyedot air hanya bisa dilakukan oleh pemilik modal besar (petani/pengusaha kaya). Mereka akan memperoleh keuntungan lebih banyak dari hasil panen sayuran di musim kemarau, karena harga dan kualitas produk yang dihasilkan pada off-season sangat baik. Fakta ini dapat mendorong para petani lainnya untuk ikut-ikutan menanam sayuran yang bernilai ekonomi tinggi secara besar-besaran pada musim kemarau, sehingga terjadi proses seperti bola salju.

b. Berdasarkan peraturan, pengambilan air langsung dari sungai dan mata air (air permukaan) harus dengan ijin atau sepengetahuan pihak berwenang. Namun untuk kasus di Kota Batu, berbagai pihak saling lempar tanggungjawab dan saling menuduh pihak lain yang memberi ijin. Masyarakat mencurigai adanya permainan dibalik ini semua, maksudnya pengambil air sudah membayar sejumlah uang kepada pihak atau oknum tertentu agar tidak dilarang mengambil air.

Isu-isu yang muncul di kalangan masyarakat bukannya tanpa dasar yang kuat. Analisis ekonomi menunjukkan bahwa usaha pertanian sayur dimusim kemarau sangat menguntungkan dapat dibuktikan melalui pengalaman petani di Kota Batu. Hambatan untuk produksi di musim kemarau adalah ketersediaan air bagi tanaman. Apabila air dapat dipenuhi walaupun dengan mengeluarkan biaya untuk instalasi 
jaringan pipa irigasi dan operasi pompa air, keuntungan yang diperoleh dari nilai produksi off-season masih sangat besar. Hal ini akan mendorong petani-petani lain di kawasan DAS Sumber Brantas untuk berlomba-lomba menggunakan sistem irigasi pompa.

Yang menjadi kekhawatiran adalah meluasnya praktek pengambilan air pada musim kemarau yang bisa mengakibatkan perebutan air oleh masyarakat dan yang kedua adalah bahwa praktek semacam ini hanya bisa dilakukan petani yang memiliki modal besar. Jika hal ini dibiarkan terus, dikuatirkan timbul konflik horisontal masyarakat Kota Batu.

- Menurunnya debit sungai pada musim kemarau disebabkan oleh sumber-sumber air yang mengecil dan mati karena penebangan hutan besar-besaran

- Pohon pinus mempunyai sifat rakus air dan pada musim kemarau menyerap air dari sumber air disekitarnya sehingga mata air menjadi kecil

- Pengambilan air di bagian hulu Kali Brantas untuk pertanian (irigasi) dan industri atau perusahaan yang marak terjadi akhir-akhir ini juga dianggap sebagai penyebab penurunan debit sungai pada musim kemarau.

- Mata air bisa dipulihkan kembali asal di sekitarnya ditanami pohon-pohonan, terutama yang bisa menghasilkan air seperti beringin, elo, aren, dsb.

6. Batas Penguasaan Lahan

Hutan, bagi sebagian besar masyarakat lokal adalah wilayah di mana secara tradisi merupakan kawasan yang ditumbuhi pohon-pohonan secara alami atau yang sengaja ditanam oleh negara (mulai jaman kolonial Belanda kemudian menjadi Jawatan Kehutanan dan sekarang Perum Perhutani). Bagi masyarakat lokal, tanpa adanya tanda-tanda bataspun mereka sudah mengetahui mana kawasan hutan dan mana lahan pemajakan (lahan milik warga). Namun dalam perkembangannya, ada pengaturan baru oleh Pemerintah, misalnya di DAS Sumber Brantas terdapat wilayah yang dikelola oleh Dinas Kehutanan Provinsi Jawa Timur, yakni kawasan Taman Hutan Raya R. Soerjo dengan status sebagai hutan lindung. Sebagian hutan yang lain dibawah pengelolaan Perum Perhutani KPH Malang, dengan status sebagai kawasan lindung dan kawasan produksi. Di lapangan, tidak banyak warga setempat yang mengetahui adanya perbedaan pengelolaan antara Perhutani dan Tahura. Mereka menganggap bahwa semua itu adalah hutan negara, dan siapapun pengelolanya tidak penting. Namun, ketika masyarakat mempunyai urusan terkait dengan wilayah hutan yang mereka ketahui adalah petugas di lapangan yaitu mantri dan mandor. 
Seiring dengan perkembangan dan dinamika masyarakat Kota Batu, sudah banyak warga setempat yang mengetahui apa sebenarnya terjadi di lapangan. Baik Tahura maupun Perhutani telah membuat patok-patok untuk menandai batas pengelolaan mereka walaupun belum seluruhnya terjangkau. Pemberian tanda batas wilayah tidak selalu berjalan baik, tetapi justru sering menimbulkan masalah dengan warga masyarakat sekitar. Seringkali terjadi perbedaan persepsi posisi batas wilayah hutan antara masyarakat dengan petugas. Petugas bekerja berdasarkan dokumen seperti peta $\mathrm{dsb}$, sementara masyarakat memiliki pemahaman tradisional yang dituturkan oleh orang tuanya. Petugas kebanyakan merupakan "orang baru" atau "orang luar" yang kurang mengenal sejarah lokasi tersebut. Selain itu dokumen yang digunakan sebagai dasar juga sering kurang akurat, misalnya skala peta yang terlalu kecil sehingga tidak bisa menunjukkan detil wilayah.

Perbedaan pemahaman tentang batas-batas wilayah pengelolaan hutan di Kota Batu tidak sampai menimbulkan masalah sengketa lahan antara masyarakat lokal dengan Perhutani, Perkebunan (PTPN) atau Lembaga Negara yang lain seperti yang terjadi di Kabupaten Malang (Malang Selatan). Namun, kasus-kasus kecil yang melibatkan warga secara individu dengan Perhutani dan Tahura memang terjadi di beberapa lokasi. Kesepahaman batas di lapangan perlu dituntaskan oleh berbagai pihak yang terlibat, supaya ada kejelasan tentang hak-hak dan tanggung jawab bagi pengelolanya. Hal ini akan sangat mendukung program konservasi lahan dan pengelolaan DAS Sumber Brantas.

- Hutan adalah kawasan yang ditumbuhi oleh pohon-pohonan secara alami (hutan alam) atau yang sengaja ditanami (hutan produksi) dan secara tradisi dikuasai oleh negara.

- Walaupun pohon/tegakan sudah tidak ada, kawasan ini masih tetap disebut sebagai hutan. 


\section{Policy Ecological Knowledge (PEK)}

\subsection{Metode dan Tahapan Kegiatan}

Secara umum ada tiga macam metode atau pendekatan yang digunakan dalam PEK. Metode atau pendekatan yang dimaksud dijelaskan sebagai berikut:

1. Metode interview mendalam (indepth interview).

2. Pertemuan stakeholder yang berkepentingan dengan DAS Sumber Brantas.

Pertemuan ini dihadiri baik oleh masyarakat lokal maupun instansi terkait di wilayah studi sebagai pengambil kebijakan.

3. Review hasil indepth interview dan pertemuan-pertemuan yang telah dilakukan oleh peneliti.

Meskipun dilakukan dengan cara yang berbeda, pada dasarnya kedua pendekatan ini ditujukan untuk menggali dan mengkaitkan pengetahuan, pengalaman serta persepsi dari stakeholder-stakeholder yang mempunyai peran dan pengaruh langsung terhadap pengelolaan DAS Sumber Brantas, khususnya stakeholder yang berasal dari institusi pemerintahan (pengambil keputusan).

Sesuai dengan metode yang dikembangkan oleh World Agroforestry Centre tentang "Rapid Hydrological Appraisal in the context of Environmental Services Reward", beberapa tahapan kegiatan yang dilakukan dalam studi PEK antara lain adalah:

1. Scoping (identifikasi secara cepat) isu-isu yang berkembang di wilayah studi.

2. Penentuan kerangka kerja spasial berupa penentuan lokasi survei baik untuk survei PEK maupun LEK. Penentuan lokasi survei ini dilakukan melalui analisa spasial yang akan memberikan informasi tentang batas-batas catchment dan administrasi.

3. Perencanaan interview untuk survei PEK.

4. Identifikasi stakeholder dan isu di lapangan.

5. Knowledge articulation. Merupakan kegiatan pengumpulan persepsi stakeholder melalui interview yang telah dijadwalkan.

6. Kompilasi dan evaluasi data persepsi dan pengetahuan stakeholder dari kelompok pengambil kebijakan (policy maker). 
Namun demikian, karena kondisi di DAS Sumber Brantas sendiri yang berbeda serta adanya kemungkinan keterbatasan waktu dari stakeholder akibat dari kesibukan mereka untuk melaksanakan wawancara mendalam, maka beberapa penyesuaian dilakukan terhadap metode PEK yang dilakukan pada studi RHA di DAS Sumber Brantas. Tahapan kegiatan yang dilakukan dalam kegiatan survei PEK ini dituangkan dalam langkah atau tahapan sebagai berikut.

\subsubsection{Scoping}

A. Pada fase scoping, informasi dikumpulkan melalui pengumpulan database yang relevan dengan studi yang didapatkan dari literatur baik dari web site (internet) maupun laporan-laporan lainnya tentang kondisi fisik, sosial, ekonomi dan politik yang berhubungan dengan kondisi hidrologi di DAS Sumber Brantas.

B. Diskusi internal peneliti dilaksanakan untuk mengumpulkan isu dan permasalahan di lokasi studi. Isu dan permasalahan yang didiskusikan merupakan hasil pengalaman peneliti di DAS Sumber Sumber Brantas.

C. Pengumpulan laporan-laporan serta data spasial berupa peta-peta yang dipergunakan untuk mengidentifikasi isu permasalahan serta stakeholder yang mungkin untuk menjadi narasumber (responden).

D. Kegiatan selanjutnya adalah ikut serta dalam acara "Semiloka dan Diskusi Sehari DAS Brantas" yang dilakukan pada bulan Juli 2008. Pada kegiatan ini, mulai dikumpulkan isu-isu serta permasalahan di lokasi studi dari stakeholder terkait.

\subsubsection{Spatial Framework}

A. Pada tahap ini, pengumpulan peta-peta topografi dilakukan sebagai bahan informasi untuk pelaksanaan survei PEK maupun LEK serta persiapan database spasial yang diperlukan.

B. Dari peta batas catchment yang didapatkan, DAS Sumber Brantas sebagian besar wilayahnya terletak di Kota Batu dan sebagian kecil di wilayah Kabupaten Malang. Kondisi geografi ini berpengaruh terhadap pemilihan responden di tingkat institusi. Beberapa institusi yang dipilih sebagian besar berasal dari Kota Batu. Namun demikian, beberapa institusi yang berdomisili di Kabupaten Malang juga tak kalah penting berperan di DAS ini, misalnya Perum Jasa Tirta I, Perhutani KPH Malang dan PDAM Kota Malang. Stakeholder dari propinsi juga berperan banyak dalam memberikan pendapat tentang DAS Sumber Brantas dalam studi RHA. 


\subsubsection{Perencanaan Survei PEK}

A. Beberapa hal yang digali dari survei PEK adalah :

1. Apa kepentingan masing-masing pihak dalam pengelolaan DAS Sumber Brantas?

2. Apa peran yang telah dilakukan masing-masing pihak dalam pengelolaan DAS Sumber Brantas?

3. Bagaimana persepsi dan pengetahuan masing-masing pihak tentang pencapaian DAS yang sehat?

4. Apa saja isu-isu serta permasalahan yang dikemukakan masing-masing pihak tentang kondisi yang terjadi di DAS Sumber Brantas?

B. Dilakukannya kegiatan transek yang dilakukan bersama-sama dengan masyarakat lokal dan perguruan tinggi yang ditujukan agar pihak pengambil kebijakan pada khususnya mengetahui permasalahan dan kondisi nyata DAS Sumber Brantas di lapang.

\subsubsection{Identifikasi Isu dan Stakeholder}

A. Identifikasi responden yang dilakukan dalam tahap scoping kemudian dilanjutkan dengan pengidentifikasian di lapang. Informasi didapatkan pada waktu dilakukannya interview terhadap responden-responden yang telah ditetapkan sebelumnya.

B. Daftar responden yang menjadi narasumber pada studi ini berasal dari dua level pemerintahan yaitu tingkat Propinsi Jawa Timur dan tingkat Kota Batu. Daftar masing-masing institusi dari kedua level pemerintahan tersebut dijelaskan sebagai berikut.

Responden Tingkat Propinsi Jawa Timur:
a. BAPEDALDA Jatim
b. BBWS Kali Brantas
c. Dinas Kehutanan
d. Tahura R. Soerjo
e. BPDAS Brantas
f. Perum Perhutani KPH Malang
g. Perum Jasa Tirta I
h. DPU Pengairan
i. Dinas Energi dan Sumberdaya Daya Mineral (ESDM)
j. Dinas Kesehatan (Sanimas) Jatim 
k. PDAM Kota Malang

1. ESP USAID

Responden pemerintahan, legislatif dan muspika Kota Batu:

a. DPRD dan Walikota Batu

b. BAPEDA

c. Dinas Pertanian dan Kehutanan

d. Dinas Lingkungan Hidup

e. Dinas SDA dan Energi

f. Dinas Kesehatan

g. Dinas Pemukiman dan Bina Marga

h. Kantor Pemberdayaan Masyarakat

i. Kantor Koperasi dan UKM

j. PDAM Kota Batu

k. Muspika

1. LSM Harapan Pulih Sentosa

m. Yayasan Pengembangan Pedesaan (YPP)

n. Yayasan Pusaka

o. LSM Paramitra

p. Kelompok Tani Tahura (KTT)

q. Lembaga Masyarakat Desa Hutan (LMDH)

r. IPPHTI

s. HIPPAM

t. HIPPA

u. Fokal Mesra

v. Kelompok Tani

w. Serikat Petani Gunung Biru (SPGB)

x. Persatuan Pengusaha Hotel.

\subsubsection{Penggalian, Kompilasi dan Analisis Data}

Informasi yang didapatkan dari keseluruhan responden diperoleh dari interview-interview yang dilakukan oleh peneliti, baik dari pengalaman terdahulu maupun dari interview yang dilakukan pada waktu dilaksanakannya studi. Informasi-informasi yang didapatkan baik yang tercatat maupun terekam dalam alat perekam kemudian dikumpulkan dan didiskusikan antar peneliti. Point-point yang didapatkan dari hasil interview kemudian dipilah-pilah sesuai dengan topik pertanyaan yang telah ditetapkan, untuk kemudian dianalisa lebih lanjut. 


\subsection{Persepsi dan Pengetahuan Para Pengambil Kebijakan terhadap Fungsi DAS}

\section{Analisis Stakeholder: kepentingan dan perannya}

Analisa stakeholder menunjukkan bahwa perhatian terhadap fungsi DAS relatif tinggi, namun diantara stakeholder masih belum jelas integrasi target-target pengelolaan DAS yang digarap serta indikator kinerja yang dihasilkan dalam memperbaiki kondisi hidrologi DAS. Setiap stakeholder merencanakan dan melakukan tindakan pengelolaan DAS secara sektoral yang disesuaikan dengan kepentingan dan mandat masing-masing instansi. Rencana dan tindakan pengelolaan DAS oleh setiap instansi ini bisa berbeda tetapi tidak jarang terjadi tumpangtindih kegiatan maupun sasaran yang dituju. Koordinasi sudah sangat sering diwacanakan bahkan pertemuan koordinasi antar pihak juga sudah menjadi agenda bersama, namun istilah koordinasi masih sebatas pertemuan belum sampai pada tindakan nyata. Sampai sejauh ini perencanaan dan tindakan pengelolaan DAS belum didasarkan pada integrasi kesepakatan stakeholder dalam menetapkan prioritas pengelolaan DAS.

Dalam analisis kepentingan dan peran stakeholder pengelolaan hidrologi DAS di Kota Batu berikut ini dipisahkan antara stakeholder dari luar (tingkat Provinsi dan Pusat) dan stakeholder dari dalam wilayah Kota Batu.

\subsubsection{Kepentingan dan Peran Stakeholder Tingkat Pusat dan Provinsi}

Kegiatan perencanaan dan pengelolaan hidrologi DAS yang terkait dengan stakeholder tingkat Provinsi Jawa Timur dan tingkat pusat baik secara langsung maupun tidak langsung ternyata cukup banyak dilakukan di wilayah Kota Batu, walaupun luasnya "hanya" sekitar $170 \mathrm{~km}^{2}$ ini. Beberapa instansi pada tingkat lebih tinggi sangat berkepentingan dengan kawasan ini, yang merupakan bagian hulu dari sebuah DAS yang dihuni oleh penduduk yang sangat besar jumlahnya di bagian yang paling strategis dari Provinsi Jawa Timur.

Beberapa stakeholder di tingkat Provinsi Jawa Timur yang terkait dengan pengelolaan hidrologi DAS Sumber Brantas adalah Badan Pengendalian Dampak Lingkungan Daerah (Bapedalda), Dinas Kehutanan, Dinas Pekerjaan Umum Pengairan, Dinas Kesehatan, Dinas Enerji dan Sumberdaya Mineral. Sementara itu beberapa dinas dan instansi lain yang secara tidak langsung juga sering berhubungan dengan isu DAS adalah Dinas Pertanian, Dinas Peternakan dan Badan Pemberdayaan Masyarakat (Bapemas). Kelompok berikutnya adalah instansi atau lembaga pusat yang beroperasi di daerah seperti Balai Besar Wilayah Sungai (BBWS) Kali Brantas, Perum Jasa Tirta I (PJT), Perum Perhutani KPH Malang, dan Balai Pengelolaan DAS Brantas (BP DAS). Pihak lain yang berperan dalam bidang ini di Kota Batu adalah Environmental Services Program (ESP)-USAID Jawa Timur, sebuah LSM international yang memiliki kegiatan di tingkat nasional. Sebenarnya masih ada pihak luar 
lain yang juga berperan yakni dari Perguruan Tinggi yang ada di Kota Malang seperti Universitas Brawijaya (UB), Universitas Islam Malang (UNISMA) dan Universitas Muhamadiyah Malang (UMM).

Berikut ini diuraikan secara ringkas dalam matriks kepentingan setiap pihak dalam pengelolaan DAS, kemudian peran yang sudah dilakukan dalam pengelolaan DAS Sumber Brantas serta persepsi dan pengetahuan masing-masing stakeholder terhadap pencapaian DAS yang sehat (Tabel 4.1.).

Tabel 4.1. Kepentingan dan Peran Stakeholder Pemerintah/non-Pemerintah Tingkat Pusat dan Provinsi dalam Pengelolaan DAS Sumber Brantas

\begin{tabular}{|c|c|c|c|}
\hline $\begin{array}{l}\text { Stakeholder } \\
\text { (Stakeholder) }\end{array}$ & $\begin{array}{l}\text { Kepentingan dalam } \\
\text { pengelolaan DAS }\end{array}$ & $\begin{array}{l}\text { Peran yang dilakukan dalam } \\
\text { pengelolaan DAS Sumber Brantas }\end{array}$ & $\begin{array}{l}\text { Persepsi dan } \\
\text { Pengetahuan tentang } \\
\text { pencapaian DAS yang } \\
\text { sehat }\end{array}$ \\
\hline BAPEDALDA Jatim & $\begin{array}{l}\text { 1. Konservasi Sumber Air } \\
\text { 2. Perlindungan Kualitas Air } \\
\text { 3. Pendidikan Lingkungan } \\
\text { 4. Penerapan Kebijakan } \\
\text { PROKASIH }\end{array}$ & $\begin{array}{l}\text { 1. Inventarisasi dan identifikasi } \\
\text { sumber-sumber air dan sumber } \\
\text { pencemar } \\
\text { 2. Menetapkan pedoman perhitungan } \\
\text { daya tamping beban pencemaran } \\
\text { 3. Menetapkan persyaratan } \\
\text { pembuangan air limbah ke air atau } \\
\text { sumber air } \\
\text { 4. Memantau kualitas air pada } \\
\text { sumber air dan badan sungai }\end{array}$ & $\begin{array}{l}\text { Sungai Brantas merupakan } \\
\text { salah satu bahan baku air } \\
\text { minum bagi penduduk Jawa } \\
\text { Timur telah tercemari oleh } \\
\text { buangan limbah domestik } \\
\text { dan limbah industri, untuk } \\
\text { itu perlu dibentuk lembaga } \\
\text { tersendiri dalam } \\
\text { menetapkan kebijakan, } \\
\text { perencanaan, pengendalian } \\
\text { dan pengawasan bidang } \\
\text { pembangunan lingkungan } \\
\text { hidup }\end{array}$ \\
\hline BBWS Kali Brantas & Pengelolaan air sungai & $\begin{array}{l}\text { 1. Perencanaan konservasi } \\
\text { sumberdaya air dalam DAS } \\
\text { 2. Pembangunan ckhek Dam untuk } \\
\text { mengurangi sedimentasi waduk }\end{array}$ & $\begin{array}{l}\text { Infrastruktur pengelolaan } \\
\text { sumberdaya air di } \\
\text { sepnajang sungai } \\
\text { terganggu fungsinya karena } \\
\text { sedimentasi, sampah dan } \\
\text { banjir }\end{array}$ \\
\hline $\begin{array}{l}\text { Dinas Kehutanan } \\
\text { Jawa Timur }\end{array}$ & $\begin{array}{l}\text { Koordinasi antar lembaga } \\
\text { teknis untuk pengelolaan } \\
\text { hutan yang disesuaikan } \\
\text { dengan kebijakan Gubernur } \\
\text { dalam pengelolaan hutan }\end{array}$ & $\begin{array}{l}\text { 1. Koordinasi Forum DAS yang } \\
\text { ditetapkan berdasarkan SK } \\
\text { Gubernur, } \\
\text { 2. Koordinasi pelaksanaan Gerakan } \\
\text { Nasional Rehabilitasi Hutan dan } \\
\text { Lahan (GN-RHL), } \\
\text { 3. Inisiasi Kebijakan Perda untuk } \\
\text { pengetrapan Jasa Lingkugan }\end{array}$ & $\begin{array}{l}\text { Pendayagunaan potensi } \\
\text { sumberdaya alam, hutan, } \\
\text { sarana prasarana serta } \\
\text { pemberdayaan masyarakat } \\
\text { untuk mendorong } \\
\text { perekonomian rakyat }\end{array}$ \\
\hline Tahura R Soerjo & $\begin{array}{l}\text { Konservasi biodiversitas } \\
\text { hutan, konservasi } \\
\text { sumberdaya air. }\end{array}$ & $\begin{array}{l}\text { Perlindungan hutan melalui } \\
\text { pembentukan dan memfungsikan } \\
\text { Kelompok Tani Tahura (KTT), } \\
\text { Paguyuban Kepala Desa dan Jaga } \\
\text { Wana dari masyarakat setempat }\end{array}$ & \\
\hline BP DAS Brantas & $\begin{array}{l}\text { Implementasi Pengelolaan } \\
\text { DAS melalui pendekatan DAS } \\
\text { Mikro, Mengaktifkan forum } \\
\text { DAS, Monitoring dan evaluasi } \\
\text { kinerja DAS }\end{array}$ & $\begin{array}{l}\text { 1. Koordinasi implementasi Gerakan } \\
\text { Nasional Rehabilitasi Hutan dan } \\
\text { Lahan (GN-RHL), } \\
\text { 2. Penyelenggaraan pertemuan rutin } \\
\text { forum DAS, } \\
\text { 3. Monitoring dan evaluasi hidrologi } \\
\text { DAS }\end{array}$ & $\begin{array}{l}\text { Implementasi DAS Mikro } \\
\text { sebagai kegiatan Forum } \\
\text { DAS dapat membantu } \\
\text { penyehatan DAS }\end{array}$ \\
\hline $\begin{array}{l}\text { Perum Perhutani } \\
\text { KPH Malang }\end{array}$ & $\begin{array}{l}\text { Pengusahaan hutan melalui } \\
\text { pendekatan Pengelolaan } \\
\text { Hutan Bersama Masyarakat } \\
\text { (PHBM) }\end{array}$ & $\begin{array}{l}\text { 1. Perencanaan, Pemeliharaan dan } \\
\text { Pengawasan usaha di sektor } \\
\text { kehutanan baik di kawasan hutan } \\
\text { lindung maupun produksi, } \\
\text { 2. Fasilitasi Lembaga Masyarakat } \\
\text { Desa Hutan dalam implementasi } \\
\text { PHBM, }\end{array}$ & $\begin{array}{l}\text { Kerjasama pengelolaan } \\
\text { hutan melalui PHBM } \\
\text { dengan masyakat dan } \\
\text { stakeholder yang } \\
\text { berkepentingan dalam } \\
\text { pengelolaan hutan atas } \\
\text { dasar Forest Resource }\end{array}$ \\
\hline
\end{tabular}




\begin{tabular}{|c|c|c|c|}
\hline $\begin{array}{l}\text { Stakeholder } \\
\text { (Stakeholder) }\end{array}$ & $\begin{array}{l}\text { Kepentingan dalam } \\
\text { pengelolaan DAS }\end{array}$ & $\begin{array}{l}\text { Peran yang dilakukan dalam } \\
\text { pengelolaan DAS Sumber Brantas }\end{array}$ & $\begin{array}{l}\text { Persepsi dan } \\
\text { Pengetahuan tentang } \\
\text { pencapaian DAS yang } \\
\text { sehat }\end{array}$ \\
\hline & & 3. Rehabilitasi hutan rusak & $\begin{array}{l}\text { Management dan } \\
\text { Community Based Forest } \\
\text { Management dapat } \\
\text { mengembalikan fungsi } \\
\text { hidrologi hutan }\end{array}$ \\
\hline Perum Jasa Tirta I & $\begin{array}{l}\text { Pengusahaan sumberdaya air } \\
\text { dengan pemanfaatan } \\
\text { infrastruktur bangunan air di } \\
\text { sepanjang sungai Kali } \\
\text { Brantas, namun menghadapi } \\
\text { masalah bahwa sumber daya } \\
\text { air yang dikelola } 85 \% \text { bukan } \\
\text { dialokasikan untuk kegiatan } \\
\text { komersil. }\end{array}$ & $\begin{array}{l}\text { 1. Implementasi konsep jasa } \\
\text { lingkungan hulu-hilir melalui } \\
\text { pemberdayaan desa contoh, } \\
\text { 2. Monitoring kualitas dan kuantitas } \\
\text { air, } \\
\text { 3. Rehabilitasi lahan di bantaran } \\
\text { sungai, } \\
\text { 4. Pemeliharaan bangunan air dan } \\
\text { sungai di K. Brantas } \\
\text { 5. Inisiator Gerakan Nasional } \\
\text { Kemitraan Penyelamatan Air (GN- } \\
\text { KPA) dengan memfasilitasi } \\
\text { Penyusunan Rencana Konservasi } \\
\text { Tanah Desa (RKTD) dan } \\
\text { implementasinya. } \\
\text { Mendukung kegiatan GN-RHL }\end{array}$ & $\begin{array}{l}\text { Kerusakan hutan dan lahan } \\
\text { berdampak terhadap } \\
\text { tingginya tingkat erosi dan } \\
\text { sedimentasi dan } \\
\text { mengancam kelestarian } \\
\text { sumberdaya air. Kondisi ini } \\
\text { dapat menurunkan fungsi } \\
\text { infrastruktur bangunan air } \\
\text { yang telah di bangun } \\
\text { dengan investasi yang } \\
\text { sangat tinggi. }\end{array}$ \\
\hline $\begin{array}{l}\text { Dinas Pekerjaan } \\
\text { Umum Pengairan } \\
\text { Jatim }\end{array}$ & $\begin{array}{l}\text { Koordinasi antar lembaga } \\
\text { teknis untuk pengelolaan } \\
\text { sumber daya air yang } \\
\text { disesuaikan dengan kebijakan } \\
\text { Gubernur dalam pengelolaan } \\
\text { SDA }\end{array}$ & $\begin{array}{l}\text { Perencanaan infrastruktur jaringan } \\
\text { irigasi }\end{array}$ & $\begin{array}{l}\text { Pemanfaatan sumberdaya } \\
\text { air untuk irrigasi }\end{array}$ \\
\hline $\begin{array}{l}\text { Dinas Energi dan } \\
\text { Sumber daya } \\
\text { Mineral Jatim }\end{array}$ & $\begin{array}{l}\text { Pemanfaatan dan konservasi } \\
\text { sumber daya air bawah tanah }\end{array}$ & Kajian geo-hidrologi (geo-listrik) & $\begin{array}{l}\text { Pemenuhunan kebutuhan } \\
\text { air melalui cadangan air } \\
\text { bawah tanah }\end{array}$ \\
\hline $\begin{array}{l}\text { Dinas Kesehatan } \\
\text { (Sanimas) Jatim }\end{array}$ & $\begin{array}{l}\text { Peningkatan kesehatan } \\
\text { masyarakat melalui sanitasi } \\
\text { lingkungan }\end{array}$ & $\begin{array}{l}\text { Penanganan limbah industri dan } \\
\text { domestik di Desa Temas secara } \\
\text { komunal dengan bangunan "wetland" }\end{array}$ & $\begin{array}{l}\text { Peningkatan kualitas air di } \\
\text { badan sungai dan kualitas } \\
\text { air yang dikonsumsi } \\
\text { masyarakat }\end{array}$ \\
\hline PDAM Kota Malang & $\begin{array}{l}\text { Mempertahankan pasokan air } \\
\text { untuk kebutuhan air minum } \\
\text { kota Malang yang secara } \\
\text { historis infrastrukturnya telah } \\
\text { dibangun sejak Jaman } \\
\text { Belanda, namun dengan } \\
\text { otonomi daerah saat ini } \\
\text { masuk wilayah Kota batu }\end{array}$ & $\begin{array}{l}\text { Pengembangan negoisasi harga air } \\
\text { baku dengan Pemkot Batu }\end{array}$ & $\begin{array}{l}\text { Konservasi sumber air baku } \\
\text { dibutuhkan untuk } \\
\text { keberlanjutan penyediaan } \\
\text { air baku warga Kota Malang }\end{array}$ \\
\hline $\begin{array}{l}\text { Environmental } \\
\text { Service Propram } \\
\text { (ESP)- USAID }\end{array}$ & $\begin{array}{l}\text { Penanganan kesehatan balita } \\
\text { terhadap diare melalui } \\
\text { pendidikan kesehatan } \\
\text { masyarakat, sanitasi } \\
\text { lingkungan, penanganan } \\
\text { sampah, penyediaan air } \\
\text { bersih masyarakat dan } \\
\text { perlindungan air melalui } \\
\text { pengelolaan DAS }\end{array}$ & $\begin{array}{l}\text { Pemberdayaan masyarakat melalui } \\
\text { sekolah lapangan pengelolaan } \\
\text { lingkungan, fasilitasi LMDH untuk } \\
\text { implementasi PHBM, pengelolaan } \\
\text { sampah dan sanitasi masyarat, inisiasi } \\
\text { pembentukan forum pengelolaan } \\
\text { lingkungan, Fasilitasi komunikasi tree } \\
\text { parties dalam pengelolaan lingkungan }\end{array}$ & $\begin{array}{l}\text { Integrasi hulu hilir terhadap } \\
\text { pengelolaan sumberdaya } \\
\text { air untuk mendukung } \\
\text { kesehatan balita terhadap } \\
\text { diare. }\end{array}$ \\
\hline $\begin{array}{l}\text { UB (Universitas } \\
\text { Brawijaya) }\end{array}$ & $\begin{array}{l}\text { Penelitian, Pendidikan dan } \\
\text { Pengabdian pada Masyarakat }\end{array}$ & $\begin{array}{l}\text { 1. Fasilitasi Pemkot dan Masyarakat } \\
\text { Kota Batu dalam pengelolaan DAS } \\
\text { 2. Peningkatan kualitas SDM lewat } \\
\text { pelatihan dan pendampingan } \\
\text { langsung dan tidak langsung } \\
\text { 3. Peningkatan kapasitas Pemkot } \\
\text { danLSM lokal } \\
\text { 4. Fasilitasi pengembangan konsep } \\
\text { pengelolaan DAS }\end{array}$ & \\
\hline $\begin{array}{l}\text { UNISMA } \\
\text { (Universitas Islam } \\
\text { Malang) }\end{array}$ & $\begin{array}{l}\text { Penelitian, Pendidikan dan } \\
\text { Pengabdian pada Masyarakat }\end{array}$ & $\begin{array}{l}\text { 1. Fasilitasi Masyarakat Kota Batu } \\
\text { dalam peningkatan pendapatan } \\
\text { melalui berbagai program kegiatan } \\
\text { masyarakat } \\
\text { 2. Peningkatan kapasitas masyarakat }\end{array}$ & \\
\hline
\end{tabular}




\begin{tabular}{llll}
\hline $\begin{array}{l}\text { Stakeholder } \\
\text { (Stakeholder) }\end{array}$ & $\begin{array}{l}\text { Kepentingan dalam } \\
\text { pengelolaan DAS }\end{array}$ & $\begin{array}{l}\text { Peran yang dilakukan dalam } \\
\text { pengelolaan DAS Sumber Brantas }\end{array}$ & $\begin{array}{l}\text { Persepsi dan } \\
\text { Pengetahuan tentang } \\
\text { pencapaian DAS yang } \\
\text { sehat }\end{array}$ \\
\hline $\begin{array}{l}\text { UMM (Universitas } \\
\begin{array}{l}\text { Muhamadiyah } \\
\text { Malang) }\end{array}\end{array}$ & $\begin{array}{l}\text { Penelitian, Pendidikan dan } \\
\text { Pengabdian pada Masyarakat }\end{array}$ & $\begin{array}{l}\text { 3. Fasilitasi Pemkot dan Masyarakat } \\
\text { Kota Batu dalam pengelolaan DAS } \\
\text { (GNKPA) } \\
\text { Fasilitasi pengembangan konsep } \\
\text { pengelolaan DAS }\end{array}$ \\
\hline
\end{tabular}

\subsubsection{Kepentingan dan Peran Stakeholder Tingkat Kota}

Identifikasi terhadap stakeholder yang berperan dalam kegiatan perencanaan dan pengelolaan hidrologi DAS Sumber Brantas menghasilkan sederet stakeholder baik dari lembaga pemerintah maupun non-pemerintah di Kota Batu.

Stakeholder yang terkait dengan pengelolaan DAS dari lembaga pemerintah adalah lembaga legislatif (DPRD), Walikota Batu, Badan Perencanaan Pembangunan Daerah (Bappeda), Dinas Pertanian dan Kehutanan, Dinas Lingkungan Hidup, Dinas Bina Marga dan Pengairan, Dinas Kesehatan, Dinas Cipta Karya dan Pemukiman, Kantor Pemberdayaan Masyarakat dan Kantor Koperasi dan UKM, PDAM Kota Batu, dan MUSPIKA (Musyawarah Pimpinan Kecamatan) Batu, Bumiaji dan Junrejo.

Daftar stakeholder non-pemerintah yang berperan aktif dalam konteks pengelolaan DAS di Kota Batu adalah Harapan Putih Sentosa, Yayasan Pengembangan Pedesaan (YPP), Yayasan Pusaka, Paramitra Jawa Timur, Fokal Mesra, (dari kelompok LSM), dari kelompok petani seperti Kelompok Tani Tahura (KTT), Lembaga Masyarakat Desa Hutan (LMDH), IPPHTI, Kelompok Tani (Buah, Bunga dan Sayur), dan Serikat Petani Gunung Biru (SPGB), serta dari kelompok pengusaha HIPPAM, Persatuan Hotel dan Restoran Indonesia (PHRI).

Sebagai sebuah catatan sejarah, bahwa sebelum tahun 1990an Batu merupakan kota kecamatan yang menjadi salah satu bagian dari Kabupaten Malang. Pada 6 Maret 1993, dibentuk dan diresmikan Kota Administrasi Batu yang meliputi wilayah Kecamatan Batu, Kecamatan Bumiaji dan Kecamatan Junrejo. Barulah pada 21 Juni 2001 status Batu resmi menjadi Kota berdasarkan UU No 11 Tahun 2001. Kota Batu menjadi daerah otonomi dipimpin seorang Walikota. Walikota Batu pertama, Imam Kabul menjabat pada periode 2001 s/d 2007. Sebelum pilkada bulan Oktober 2007, Walikota meninggal dunia (26 Agustus 2007), sehingga jabatan walikota Batu dipegang oleh seorang pelaksana harian (plh), sampai terpilihnya walikota definitif. Pilkada baru dilaksanakan 5 Nopember 2007 dan terpilih pasangan Walikota Eddy Rumpoko dan Wakil Walikota H. Achmad Budiono, SH. MM, yang dilantik pada pada hari Senin 23 Desember 2007, setelah memenangkan pilkada pada 5 November 2007 lalu. 
Terjadi ketidak-pastian di kalangan birokrasi Kota Batu sejak meninggalnya Walikota Imam Kabul sehingga banyak hal yang menyangkut kebijakan seolah diambangkan karena menunggu kepastian walikota yang baru. Demikian pula sejak walikota Eddy Rumpoko dilantik sampai masih terjadi suasana yang mengambang, karena adanya isu perubahan organisasi dan mutasi jabatan di lingkungan SKPD Kota Batu. Hal ini ternyata sangat berpengaruh terhadap sikap dan kebijakan yang diambil oleh beberapa dinas, khususnya yang terkait dengan penelitian RHA, yakni sebagai stakeholder dari lembaga pemerintah (PEK). Isu tersebut akhirnya menjadi kenyataan pada bulan Desember 2008, di mana terjadi perubahan yang cukup besar di beberapa SKPD yang terkait dengan penelitian RHA ini. Selain mutasi pejabat atau pimpinan SKPD ternyata juga ada perubahan struktur organisasi beberapa SKPD. Perubahan SKPD yang terkait dengan isu pengelolaan DAS pada bulan Desember 2008 adalah sebagai berikut :

\begin{tabular}{lll} 
2001-Desember 2008 & Mulai Desember 2008 \\
\hline Dinas Kehutanan dan Lingkungan Hidup & menjadi & Dinas Lingkungan Hidup \\
Dinas Sumberdaya Air dan Enerji & menjadi & Dinas Pengairan dan Bina Marga \\
Dinas Pertanian dan Peternakan & menjadi & Dinas Pertanian dan Kehutanan \\
\hline
\end{tabular}

Berikut ini diuraikan secara ringkas dalam matriks kepentingan setiap pihak dalam pengelolaan DAS, kemudian peran yang sudah dilakukan dalam pengelolaan DAS Sumber Brantas serta persepsi dan pengetahuan masing-masing stakeholder terhadap pencapaian DAS yang sehat (Tabel 4.2.). 
Tabel 4.2. Kepentingan dan Peran Stakeholder Pemerintah/non-Pemerintah Tingkat Kota Batu dalam Pengelolaan DAS Sumber Brantas

\begin{tabular}{|c|c|c|c|}
\hline $\begin{array}{l}\text { Stakeholder } \\
\text { (Stakeholder) }\end{array}$ & Kepentingan dalam pengelolaan DAS & Peran yang dilakukan dalam pengelolaan DAS Sumber Brantas & $\begin{array}{c}\text { Persepsi dan Pengetahuan } \\
\text { tentang pencapaian DAS yang } \\
\text { sehat }\end{array}$ \\
\hline $\begin{array}{l}\text { DPRD dan Wali } \\
\text { Kota }\end{array}$ & $\begin{array}{l}\text { Implementasi visi tahun 2003-2007 "Batu, } \\
\text { Agropolitan bernuansa pariwisata dengan } \\
\text { masyarakat madani", menuju visi } 2007-2012 \text { : } \\
\text { Kota Batu sebagai sentra pariwisata berbasis } \\
\text { pertanian, didukung oleh sumberdaya manusia, } \\
\text { sumberdaya alam, dan sumberdaya budaya } \\
\text { serta pemerintahan yang kreatif, inovatif, dan } \\
\text { bersih bagi seluruh rakyat yang dijiwai keimanan } \\
\text { dan ketaqwaan kepada Tuhan Yang Maha Esa }\end{array}$ & $\begin{array}{l}\text { 1. Penetapan Missi : (a) Pening-katan SDM untuk mengelola Sumber Daya } \\
\text { Alam berbasis pertanian dan pariwisata yang berwawasan lingkungan, } \\
\text { dan (b) Perwujudan peningkatan lingkungan hidup dan terkenda-linya } \\
\text { tata ruang daerah } \\
\text { 2. Penerbitan Peraturan Daerah No. } 6 \text { / } 2005 \text { tentang Perlin-dungan dan } \\
\text { Pengelolaan Air Bawah Tanah dan Air Permukaan } \\
\text { 3. Meningkatkan peran Kota Batu sebagai Kota pertanian (agro-politan), } \\
\text { khususnya untuk jenis tanaman sayur, buah dan bunga serta } \\
\text { menguatnya perdagangan hasil pertanian dan industri pertanian (agro- } \\
\text { industri) yang diperhitungkan, } \\
\text { 4. Meningkatkan posisi dan peran Kota Batu dari "Kota Wisata" menjadi } \\
\text { "sentra Wisata" yang diperhitungkan di tingkat regional atau bahkan } \\
\text { nasional }\end{array}$ & $\begin{array}{l}\text { Pengembangan agropolitan dan } \\
\text { wisata yang didukung penerapan } \\
\text { motto "Batu Hijau Lestari" dengan } \\
\text { pendekatan kultural dan struktural }\end{array}$ \\
\hline BAPPEDA & $\begin{array}{l}\text { Mewujudkan Tata Ruang Daerah dengan } \\
\text { Penetapan Kawasan Lindung, Luasnya sekitar } \\
52 \%(10,352 \mathrm{Ha}) \text { dan Kawasan Budidaya } 48 \% \\
(9,555 \mathrm{Ha}) \text { dari luas wilayah Kota Batu. }\end{array}$ & $\begin{array}{l}\text { 1. Pemetaan dan penyusunan data spatial untuk perencanaan tata ruang, } \\
\text { 2. Koordinasi Instansi terkait untuk implementasi tararuang daerah }\end{array}$ & $\begin{array}{l}\text { Penerapan tata ruang daerah dapat } \\
\text { menciptakan lingkungan yang sehat }\end{array}$ \\
\hline $\begin{array}{l}\text { Dinas Pertanian } \\
\text { dan Kehutanan }\end{array}$ & $\begin{array}{l}\text { Peningkatan Peran Serta Masyarakat dalam } \\
\text { Rehabilitasi Hutan dan Lahan } \\
\text { Peningkatan kualitas lingkungan } \\
\text { hidup dengan penanganan lahan kritis, baik di } \\
\text { dalam maupun di luar kawasan } \\
\text { hutan. }\end{array}$ & $\begin{array}{l}\text { 1. Bantuan Ternak untuk mendu-kung rehabilitasi hutan } \\
\text { 2. membina Kelompok Tani LMDH dan RLKT; } \\
\text { 3. Sosialisasi Pencegahan dan Dampak Kebakaran Hutan dan Lahan } \\
\text { 4. Perlindungan dan Pengamatan Hutan Terpadu }\end{array}$ & $\begin{array}{l}\text { Pengelolaan hutan dengan } \\
\text { pemberdayaan perikehidupan dan } \\
\text { perekonomian masyakat solusi } \\
\text { konservasi dan rehabilitasi hutan dan } \\
\text { kerusakan sumberdaya lahan dan } \\
\text { mengupayakan mitigasi dan adaptasi } \\
\text { pemanasan global }\end{array}$ \\
\hline $\begin{array}{l}\text { Dinas Lingkungan } \\
\text { Hidup }\end{array}$ & $\begin{array}{l}\text { Pengelolaan lingkungan hidup untuk menjamin } \\
\text { kualitas air dan sanitasi masyarakat }\end{array}$ & $\begin{array}{l}\text { 1. Pengembangan Teknologi Persampahan dan Pemantauan Kualitas } \\
\text { Lingkungan } \\
\text { 2. maupun Pengkajian Dampak Lingkungan termasuk Pembuatan } \\
\text { Teknologi Biogas Limbah Ternak; } \\
\text { 3. Pengelolaan Prokasih; Pengadaan Sarana dan Prasarana Pemantauan } \\
\text { Kualitas Air ; } \\
\text { 4. Peningkatan Konservasi Daerah Tangkapan Air serta Pembuatan Dam } \\
\text { Penahan; } \\
\text { 5. Pengembangan Data dan Informasi Lingkungan serta Penyuluhan } \\
\text { 6. Pengendalian Polusi dan Pencemaran; } \\
\text { 7. Penghijauan Kanan Kiri Jalan, } \\
\text { 8. Pengadaan dan Pemeliharaan Sarana dan Prasarana Pencegahan } \\
\text { Bahaya Kebakaran dan Pengelolaan Persampahan/Pemeliharaan dan }\end{array}$ & $\begin{array}{l}\text { Peningkatan peran serta masyarakat } \\
\text { dalam menjaga kelestarian } \\
\text { lingkungan hidup kota Batu }\end{array}$ \\
\hline
\end{tabular}




\begin{tabular}{|c|c|c|c|}
\hline $\begin{array}{l}\text { Stakeholder } \\
\text { (Stakeholder) }\end{array}$ & Kepentingan dalam pengelolaan DAS & Peran yang dilakukan dalam pengelolaan DAS Sumber Brantas & $\begin{array}{c}\text { Persepsi dan Pengetahuan } \\
\text { tentang pencapaian DAS yang } \\
\text { sehat }\end{array}$ \\
\hline & & $\begin{array}{l}\text { Pengembangan } \\
\text { 9. Ruang Terbuka Hijau. }\end{array}$ & \\
\hline $\begin{array}{l}\text { Dinas Bina Marga } \\
\text { dan Pengairan }\end{array}$ & $\begin{array}{l}\text { mewujudkan pola } \\
\text { pengelolaan sumber daya air yang terpadu dan } \\
\text { berkelanjutan, terkendalinya } \\
\text { pemanfaatan air tanah, meningkatnya } \\
\text { kemampuan pemenuhan kebutuhan air } \\
\text { bagi rumah tangga, permukiman, pertanian, dan } \\
\text { industri, dengan prioritas utama } \\
\text { untuk kebutuhan pokok masyarakat serta } \\
\text { berkurangnya dampak bencana banjir } \\
\text { dan kekeringan. }\end{array}$ & $\begin{array}{l}\text { 1. Pembangunan dan pemeliharaan saluran irigasi, dam, pembuatan } \\
\text { plengsengan dan penguatan tebing sungai, } \\
\text { 2. Pelayanan Sistem Irigasi } \\
\text { 3. Pengembangan penampungan air melalui waduk mini untuk penyediaan } \\
\text { air bersih } \\
\text { 4. Pemberdayaan petani pemakai air (HIPPA) } \\
\text { 5. Pemanfaatan sumber-sumber air bersih } \\
\text { 6. Perencanaan pembangunan dan pembuatan jaringan irigasi, perencanan } \\
\text { dan pembuatan jaringan air bersih/minum. } \\
\text { 7. Pengembangan sumur bor dan reservoir untuk pengadaan air bersih } \\
\text { 8. Pengawasan Air Bersih dan Pelatihan HIPPAM serta Wasdal } \\
\text { 9. Pemanfaatan Air Bawah Tanah dan Mata Air. } \\
\text { 10. Pengembangan energi alternatif dengan biogas }\end{array}$ & $\begin{array}{l}\text { Pengelolaan sumberdaya air melalui } \\
\text { pemulihan debit sumber air utama } \\
\text { dan penataan pemanfaatan } \\
\text { sumberdaya air berdasarkan regulasi } \\
\text { pemerintah daerah }\end{array}$ \\
\hline Dinas Kesehatan & Mewujudkan Kebijakan Lingkungan Hidup Sehat & Penyelenggaraan Penyehatan Lingkungan di tempat Penyediaan Air Bersih & $\begin{array}{l}\text { Perbaikan kesehatan masyarakat } \\
\text { melalui perbaikan sanitasi konsumsi } \\
\text { air masyakarat }\end{array}$ \\
\hline $\begin{array}{l}\text { Dinas Cipta Karya } \\
\text { dan Pemukiman }\end{array}$ & $\begin{array}{l}\text { perencanaan pembangunan infrastruktur } \\
\text { pembangunan } \\
\text { Jaringan Air Minum/Air Bersih }\end{array}$ & Penyediaan jaringan air bersih baik dalam fasilitasi PDAM dan HIPAM & $\begin{array}{l}\text { Pemanfaatan sumberdaya air untuk } \\
\text { pemerataan penyediaan air bersih } \\
\text { warga masyarakat }\end{array}$ \\
\hline $\begin{array}{l}\text { Kantor } \\
\text { Pemberdayaan } \\
\text { Masyarakat }\end{array}$ & $\begin{array}{l}\text { Pengembangan usaha produktif dan } \\
\text { perlindungan lingkungan melalui bantuan } \\
\text { peberdayaan masyakat oleh aparat desa dan } \\
\text { organisasi kemasyarakatan di tingkat desa }\end{array}$ & $\begin{array}{l}\text { Bantuan dana segar untuk kegiatan masyakarat sesuai kebutuhan desa } \\
\text { yang disusun dari RESBANG Desa. }\end{array}$ & $\begin{array}{l}\text { Penguatan kelembagaan desa untuk } \\
\text { memaduan kemajuan pembangunan } \\
\text { dan perlindungan lingkungan }\end{array}$ \\
\hline $\begin{array}{l}\text { Kantor Koperasi } \\
\text { dan UKM }\end{array}$ & $\begin{array}{l}\text { Pembinaan, pelatihan dan } \\
\text { pendampingan dalam bidang kewirausahaan } \\
\text { maupun pengelolaam manajemen } \\
\text { koperasi }\end{array}$ & $\begin{array}{l}\text { Pembentukan Kelompok Kerja Program Pengembangan Usaha Kecil dan } \\
\text { Mikro serta Perkuatan Struktur Keuangan Koperasi. }\end{array}$ & $\begin{array}{l}\text { Pembinaan perekonomian } \\
\text { masyakarat desa sekitar hutan } \\
\text { melalui pengembangan koperasi }\end{array}$ \\
\hline PDAM Kota Batu & $\begin{array}{l}\text { Pengusahaan sumberdaya air untuk penyediaan } \\
\text { air bersih masyarakat }\end{array}$ & $\begin{array}{l}\text { Melakukan managemen pemafaatan air dan penyediaan infrastruktur untuk } \\
\text { penyediaan air bersih masyarakat dan industry serta perhotelan }\end{array}$ & $\begin{array}{l}\text { Pengelolaan restribusi air yang } \\
\text { sebagian digunakan untuk } \\
\text { penyelamatan sumber air disekitar } \\
\text { mata air }\end{array}$ \\
\hline MUSPIKA & $\begin{array}{l}\text { Penegakan hukum UU No } 23 \text { tahun } 1997 \\
\text { tentang Pengelolaan Hidup, UU No } 7 \text { Tahun } \\
2004 \text { tentang Sumberdaya Air, Kep Men LH No } \\
07 \text { tahun } 2001 \text { tentang Pejabat dan Pengawas } \\
\text { Lingkungan Hidup Daerah, Keputusan Bersama } \\
\text { Kementrian LH, Kejaksaaan dan Kepolisian No }\end{array}$ & $\begin{array}{l}\text { Pengawas_Penyidik bidang lingkungan hidup, Pembuktian Tindak Pidana } \\
\text { Lingkungan Hidup, Mendukung Kebijakan Pemerintah Daerah, dan } \\
\text { memfasilitasi peran masyarakat dalam mentaati peraturan perundang- } \\
\text { undangan di bidang lingkungan }\end{array}$ & $\begin{array}{l}\text { Penegakan hukum dapat mencegah } \\
\text { kerusakan lingkungan }\end{array}$ \\
\hline
\end{tabular}




\begin{tabular}{|c|c|c|c|}
\hline $\begin{array}{l}\text { Stakeholder } \\
\text { (Stakeholder) }\end{array}$ & Kepentingan dalam pengelolaan DAS & Peran yang dilakukan dalam pengelolaan DAS Sumber Brantas & $\begin{array}{c}\text { Persepsi dan Pengetahuan } \\
\text { tentang pencapaian DAS yang } \\
\text { sehat }\end{array}$ \\
\hline & $\begin{array}{l}\text { KEP -04/ MENLH/04/2004, KEP } \\
\text { 208/A/JA/04/2004, No Pol: Kep-19/IV/2004 } \\
\text { tentang Penegakan Hukum Lingkungan Hidup } \\
\text { Terpadu, Keputusan Gubernur Jatim No } 45 \\
\text { tahun } 2002 \text { tentang baku mutu limbah cair bagi } \\
\text { industry atau kegiatan usaha lainnya di Jawa } \\
\text { Timur }\end{array}$ & & \\
\hline $\begin{array}{l}\text { LSM Harapan Pulih } \\
\text { Sentosa }\end{array}$ & Fasilitasi Rehabilitasi hutan & Fasilitasi kegiatan PHBM oleh LMDH dan Perhutani & $\begin{array}{l}\text { Penguatan masyarakat untuk } \\
\text { merehabilitasi hutan }\end{array}$ \\
\hline YPP & Fasilitasi penerapan Jasa Lingkungan Hulu-hilir & $\begin{array}{l}\text { Penguatan kelembagaan kelompok tani untuk rehabilitasi lahan dan hutan, } \\
\text { menjadi mediator dalam rehabilitasi lahan }\end{array}$ & $\begin{array}{l}\text { Penguatan Kelembagaan } \\
\text { Masyarakat dapat sebagai roda } \\
\text { penggerah rehabilitasi lahan dan } \\
\text { hutan yang efektif }\end{array}$ \\
\hline Yayasan Pusaka & $\begin{array}{l}\text { Fasilitasi dan advokasi permasalahan } \\
\text { lingkungan }\end{array}$ & $\begin{array}{l}\text { Pengembangan kegiatan Gerakan Rehabilitasi Hutan dengan program } \\
\text { GIRAB }\end{array}$ & $\begin{array}{l}\text { Pendekatan cultural dan structural } \\
\text { dapat sebagai penggerak efektif } \\
\text { dalam rehabilitasi hutan dan lahan }\end{array}$ \\
\hline LSM Paramitra & $\begin{array}{l}\text { Pengembangan Jasa Linglkungan melalui } \\
\text { mekanise pengembangan peraturan daerah }\end{array}$ & $\begin{array}{l}\text { Fasilitasi pengembangan peraturan daerah tentang jasa lingkungan, fasilitasi } \\
\text { koordinasi kegiatan Tahura R Soerjo dengan masyarakat, Pengembangan } \\
\text { Perdes Lingkungan }\end{array}$ & $\begin{array}{l}\text { Penguatan kelembagaan masyarakat } \\
\text { dapat sebagai pendorong percepatan } \\
\text { rehabilitasi lahan dan hutan serta } \\
\text { konservasi kawasan lindung }\end{array}$ \\
\hline $\begin{array}{l}\text { Kelompok Tani } \\
\text { Tahura (KTT) }\end{array}$ & $\begin{array}{l}\text { Pengembangan kegiatan konservasi } \\
\text { biodiversitas dan pemanfaan fungsi hutan non } \\
\text { kayu untuk usaha produktif }\end{array}$ & $\begin{array}{l}\text { Pengembangan rencana aksi untuk konservasi biodiversitas dan } \\
\text { pemanfaatan fungsi hutan non kakyu dan pengembangan sistem } \\
\text { pengamanan hutan }\end{array}$ & $\begin{array}{l}\text { Konservasi biodiversitas hutan dapat } \\
\text { menjaga kelestarian sumberdaya air }\end{array}$ \\
\hline $\begin{array}{l}\text { Lembaga } \\
\text { Masyarakat Desa } \\
\text { Hutan (LMDH) }\end{array}$ & $\begin{array}{l}\text { Perbaikan perikehidupan anggota melalui peran } \\
\text { aktif dalam implementasi PHBM }\end{array}$ & $\begin{array}{l}\text { Penguatan pesanggem dalam rangka mendukung implementasi PHBM di } \\
\text { wilayah Perhutani }\end{array}$ & $\begin{array}{l}\text { Perbaikan perekonomian } \\
\text { pesanggem, dan kebersamaan dank } \\
\text { e solidan organisasi LMDH dapat } \\
\text { mendukung pengembangan fungsi } \\
\text { ekologis hutan }\end{array}$ \\
\hline IPPHTI & $\begin{array}{l}\text { Impelentasi pengendalian hama penyakit } \\
\text { terpadu dalam usaha budidaya pertanian }\end{array}$ & $\begin{array}{l}\text { Pengembangan dan implementasi pengendalian hama penyakit terpadu } \\
\text { yang menekan sekecil mungkin kontaminasi pestisida dalam aliran air }\end{array}$ & $\begin{array}{l}\text { Perbaikan kualias air melalui } \\
\text { implementasi Pengendalian Hama- } \\
\text { Penyakit Terpadu ( PHT) }\end{array}$ \\
\hline HIPPAM & $\begin{array}{l}\text { Penyediaan air bersih masyarakat pedesaan } \\
\text { yang murah dengan managemen masyarakat } \\
\text { desa itu sendiri }\end{array}$ & $\begin{array}{l}\text { Perencanaan, pengembangan dan pemanfaatan sumber air untuk } \\
\text { penyediaan dan pemerataan air bersih masyarakat pedesaan }\end{array}$ & $\begin{array}{l}\text { Konservasi sumber air penting untuk } \\
\text { keberlanjutan penyediaan air besih } \\
\text { kebutuhan rumah tangga }\end{array}$ \\
\hline HIPA & $\begin{array}{l}\text { Pemanfaatan dan pengelolaan air untuk irrgiasi } \\
\text { baik di lahan perkebunan apel, lahan kering dan } \\
\text { lahan sawah }\end{array}$ & Pengaturan kebutuhan air baku untuk irrigasi & $\begin{array}{l}\text { Konservasi sumber air penting untuk } \\
\text { keberlanjutan penyediaan air irigasi } \\
\text { dalam pendukung usaha pertanian }\end{array}$ \\
\hline
\end{tabular}




\begin{tabular}{|c|c|c|c|}
\hline $\begin{array}{l}\text { Stakeholder } \\
\text { (Stakeholder) }\end{array}$ & Kepentingan dalam pengelolaan DAS & Peran yang dilakukan dalam pengelolaan DAS Sumber Brantas & $\begin{array}{c}\text { Persepsi dan Pengetahuan } \\
\text { tentang pencapaian DAS yang } \\
\text { sehat }\end{array}$ \\
\hline FOKAL MESRA & $\begin{array}{l}\text { Pemantauan kondisi lingkungan dan } \\
\text { pemberdayaan masyarakat untuk pengelolaan } \\
\text { lingkungan }\end{array}$ & $\begin{array}{l}\text { Fasilitasi Masyarakat untuk pengelolaan lingkungan dan rehabilitasi hutan } \\
\text { dan lahan, pemantauan kualitas air di badan sungai }\end{array}$ & $\begin{array}{l}\text { Pemanfaatan sumberdaya alam } \\
\text { untuk kesejahteraan masyarakat } \\
\text { harus selaras alam }\end{array}$ \\
\hline Kelompok Tani & Pemanfaatan sumberdaya air untuk irrigasi & Penggunaan pestisida yang dapat menyebabkan kontaminasi aliran air & $\begin{array}{l}\text { Pengaturan pemanfaatan air yang } \\
\text { lebih efisien dan pengembangan } \\
\text { pengendalian HPT dapat } \\
\text { memperbaiki kondisi lingkungan }\end{array}$ \\
\hline $\begin{array}{l}\text { Serikat Petani } \\
\text { Gunung Biru } \\
\text { (SPGB) }\end{array}$ & $\begin{array}{l}\text { Memperjuangan anggotanya yang mayoritas } \\
\text { tidak memiliki lahan untuk mendapatkan lahan } \\
\text { garapan dihutan dengan menjaga kelestarian } \\
\text { hutan }\end{array}$ & $\begin{array}{l}\text { Pemanfaatan lahan hutan dengan mengusahakan tanaman dibawah } \\
\text { tegakan }\end{array}$ & $\begin{array}{l}\text { Konservasi Gunung Biru dengan } \\
\text { menyertakan masyarakat untuk } \\
\text { peningkatan ekonominya dapat } \\
\text { melestarikan sumberdaya air. }\end{array}$ \\
\hline $\begin{array}{l}\text { Persatuan } \\
\text { Pengusaha Hotel } \\
\text { dan Restauran } \\
\text { (PHRI) }\end{array}$ & $\begin{array}{l}\text { Pemanfaatan sumber air untuk kebutuhan usaha } \\
\text { perhotelan }\end{array}$ & Berpartisipasi dalam rehabilitasi hutan & $\begin{array}{l}\text { Pasokan air baku untuk kebutuhan } \\
\text { usaha perhotelan penting melalui } \\
\text { rehabilitasi hutan }\end{array}$ \\
\hline
\end{tabular}


PEK terkait dengan RHA di DAS Sumber Brantas menjadi sangat menarik akibat adanya periode transisi di Kota Batu. Terlihat bahwa kebijakan yang diambil oleh Dinas-dinas sangat tergantung dari figur pimpinan daerah dalam hal ini walikota. Salah satu isu penting terkait dengan RHA yang bisa dijadikan contoh adalah hubungan antara hutan dan air (banjir dan kekeringan). Semua komponen di Kota Batu tampaknya sepakat bahwa penurunan fungsi hidrologi di kawasan ini disebabkan oleh penebangan pohon di hutan kawasan Perhutani yang tidak segera dihutankan kembali. Hampir semua komponen masyarakat dan pemerintah menyadari bahwa untuk memperbaiki keadaan tersebut adalah dengan cara menghutankan kembali kawasan Perhutani dan Tahura yang gundul dan rusak. Namun kesepakatan semacam ini tidak langsung bisa diimplementasikan.

Proses penghutanan kembali terhambat oleh kegiatan masyarakat sekitar hutan yang menanami tanah-tanah gundul tersebut dengan tanaman semusim khususnya sayur-sayuran. Tanaman sayur ternyata memberikan hasil yang luar biasa besar bagi para petani, sehingga mereka enggan menghentikan kegiatannya itu. Program-program yang dikembangan pemerintah untuk membatasi penanaman sayur ternyata tidak mampu menghentikannya.

Penghutanan kembali atau menanam pohon kehutanan 100\% di lahan Perhutani jelas sudah tidak memungkinkan lagi akibat adanya keterlibatan masyarakat didalam kawasan hutan. Masyarakat tidak mungkin disingkirkan atau diusir dari kawasan itu, sehingga satu-satunya jalan adalah melibatkan mereka dalam pengelolaan hutan (konsep PHBM oleh Perhutani). Salah satu kompromi yang ditawarkan oleh Perhutani adalah mengganti tanaman sayuran dengan tanaman tahunan. Dari berbagai pilihan, ditawarkan porang dan kopi untuk ditanam disela-sela tanaman pokok (tegakan). Namun usulan masyarakat dan Perhutani ini tidak disetujui oleh birokrasi Pemkot Batu. Namun setelah pergantian walikota, justru ide ini menjadi program Pemkot Batu untuk menghentikan penanaman sayur sebagai tanaman sela di lahan Perutani dan menggantinya dengan tanaman kopi. Bahkan di awal tahun 2009 ini Pemkot Batu memberikan berbagai bentuk insentif untuk mempercepat pelaksanaan penanaman kopi ini.

Itulah salah satu contoh perubahan yang mendasar dari kebijakan yang sangat dipengaruhi oleh figur kepala daerah dalam era otonomi daerah seperti sekarang ini. Kesimpulannya, PEK yang digali dari unsur birokasi (lembaga pemerintah daerah) dapat berubah karena pengaruh dari pimpinan tertinggi di daerah tersebut.

\subsection{Isu Hidrologi Menuju DAS yang Sehat}

Perhatian utama pengambil keputusan di tingkat Pemerintah Kota Batu terkait dengan isu-isu hidrologi di DAS Sumber Brantas akan diuraikan sebagai berikut. 


\subsubsection{Tarik ulur kepentingan budidaya hortikultura di kawasan pegunungan dengan implementasi tata ruang daerah}

DAS Sumber Brantas yang sebagian besar masuk wilayah Kota Batu ditetapkan sebagai salah satu wilayah resapan air DAS Brantas. Untuk itu Pemerintah Kota Batu menetapkan Tata Ruang Wilayah dengan menetapkan kawasan lindung yang luasnya sekitar 10.352 ha atau $52 \%$ dari wilayah Kota Batu dan kawasan budidaya seluas 9.555ha atau 48\%. Sementara itu, kondisi kawasan lindung yang ada di Kota Batu pada saat ini baru mencapai 33\%. Wilayah yang semestinya sebagai kawasan lindung saat ini masih berupa semak belukar (13\%), sebagian lagi digunakan sebagai usaha tani sayuran dan kebun apel (5\%) dan sisanya sebagai lahan kering berupa tegalan yang juga diusahakan untuk usaha tani sayur-mayur.

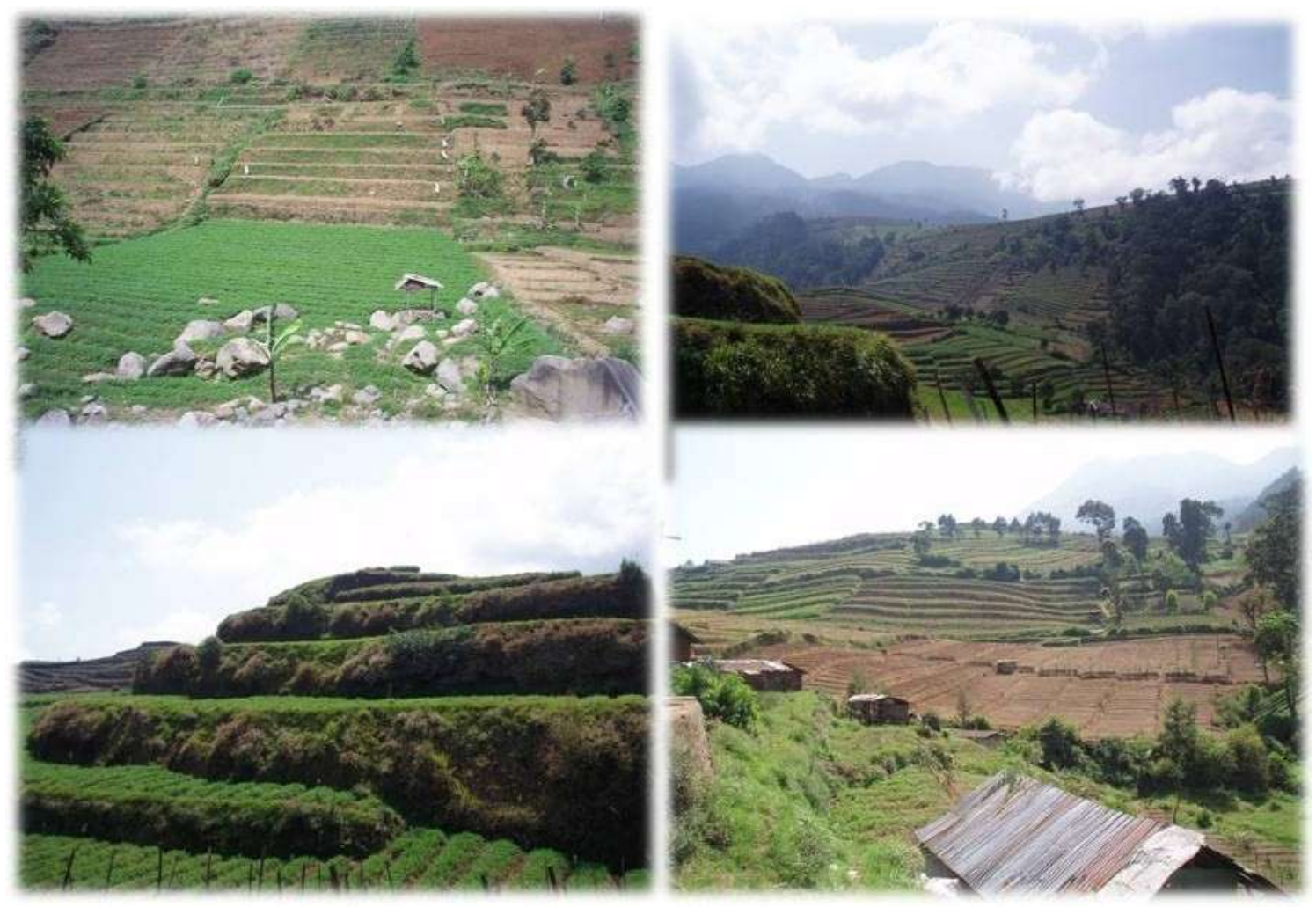

Gambar 4.1. Beberapa sudut kawasan budidaya di DAS Sumber Brantas, wilayah Kota Batu.

Secara demografis, Kota Batu yang luasnya 199,1 km² memiliki jumlah penduduk mencapai 182.885 jiwa pada tahun 2007, sehingga tingkat kepadatan penduduk di wilayah ini termasuk sangat tinggi yakni mencapai sebesar 919 orang $/ \mathrm{km}^{2}$. Demikian pula tingkat pendidikan sebagian besar masyarakat Kota Batu atau sekitar 34\% adalah tamatan SD, sementara lulusan SLTP dan SLTA masing-masing 17\%, dan sekitar 6\% adalah tamatan perguruan tinggi. Sementara itu yang tidak/belum sekolah dan tidak lulus SD mencapai sekitar $26 \%$ dari penduduk Kota Batu. 
Kondisi demografi dan tingkat pendidikan yang demikian serta didukung oleh kondisi tanah yang subur menyebabkan sebagian besar masyarakat menjatuhkan pilihan mata-pencaharian pada bidang pertanian. Sektor pertanian hortikultura (sayur, bunga dan buah-buahan) menjadi andalan masyarakat Kota Batu. Nilai ekonomi komoditas hortikultura yang sangat tinggi membuat masyarakat Kota Batu "kelaparan lahan" sehingga setiap jengkal tanah tidak ada yang tidak dimanfaatkan untuk kegiatan pertanian. Adanya kesempatan menanam sayuran di lahan Perhutani tidak disia-siakan oleh masyarakat yang tidak memiliki lahan maupun yang sudah memiliki lahan sendiri.

Pola kehidupan yang demikian memberikan dampak positif terhadap pendapatan dan pendapatan per-kapita masyarakat Kota Batu. Pendapatan per kapita masyarakat Kota Batu memperlihatkan fenomena kenaikan yang signifikan selama beberapa tahun terakhir, yaitu dari Rp 3.752.924,84 pada tahun 2001 menjadi Rp 3.865.829,88 pada tahun 2002, dan tahun 2003 sebesar Rp 3.949.952,17 kemudian pada tahun 2004 meningkat menjadi Rp 4.066.437,47 pada tahun $2005 \mathrm{Rp}$ 4.258.056,20 serta tahun 2006 menjadi Rp 4.394.253,80.

Namun sayang usaha pertanian tersebut dilakukan di kawasan resapan air dan sistem budidaya pertanian yang dilakukan seringkali kurang mengindahkan prinsip-prinsip konservasi tanah dan air. Upaya untuk mengalihkan jenis komoditas sayuran menjadi tanaman tahunan menjadi kurang menarik bagi masyarakat, mungkin karena imbalan pendapatan yang diterima tidak sepadan dengan praktek yang sekarang.

Telah terjadi tarik-ulur antara Pemerintah Kota Batu, Perum Perhutani dan masyarakat khususnya di lahan Perhutani untuk mengganti tanaman sayuran dengan tanaman tahunan yang dapat melindungi tanah dan air. Perkembangan terakhir menunjukkan bahwa sudah mulai ada titik temu antara ketiga pihak tersebut untuk mengganti tanaman sayuran dengan tanaman kopi yang akan ditanam disela-sela tegakan pohon (pinus dsb).

\subsubsection{Kerusakan ekologi hutan akibat perambahan hutan untuk budidaya tanaman sayur}

DAS Sumber Brantas yang luasnya 17.344ha atau sekitar 9.6\% dari total luas DAS Sumber Brantas merupakan salah satu bagian dari kawasan resapan sistem Kali Brantas di Jawa Timur. Antara tahun 1997 sampai tahun 2001, telah terjadi deforestasi di DAS Sumber Brantas seluas 1.597ha, yang dialih-gunakan (sementara) sebagai kawasan pertanian tanaman semusim khususnya sayuran dengan kondisi konservasi tanah dan air yang sangat memprihatinkan.

Sebagian besar deforestasi diakibatkan oleh penebangan tegakan pohon secara ilegal di kawasan hutan Perhutani, sebagai akibat ketidak-pastian ekonomi dan politik pada masa krisis moneter dan sebagai dampak dari proses otonomi daerah Kota Batu. Hal serupa juga terjadi di 
kawasan Tahura R. Soerjo, walau tidak separah di kawasan Perhutani. Masyarakat dan bahkan pejabat di Kota Batu sendiri tidak bisa mengenali batas-batas kawasan yang berada di bawah pengelolaan Perum Perhutani dan Tahura R. Soerjo, sehingga penebangan terjadi dimana-mana. Mulai tahun 2000, baik Perum Perhutani maupun Tahura R. Soerjo yang sedang berusaha melakukan rehabilitasi hutan, harus menghadapi masalah konflik kepentingan dengan masyarakat lokal yang telah merasakan keuntungan ekonomi ketika melakukan budidaya tanaman sayuran di kawasan hutan. Konflik dengan masyarakat ini timbul terutama karena adanya kesenjangan komunikasi (communication gap) atau komunikasi yang lemah antara pengetahuan masyarakat, kebijakan pemerintah Kota Batu dan kebijakan Perum Perhutani dalam menjalankan Pengelolaan Hutan Bersama Masyarakat (PHBM).
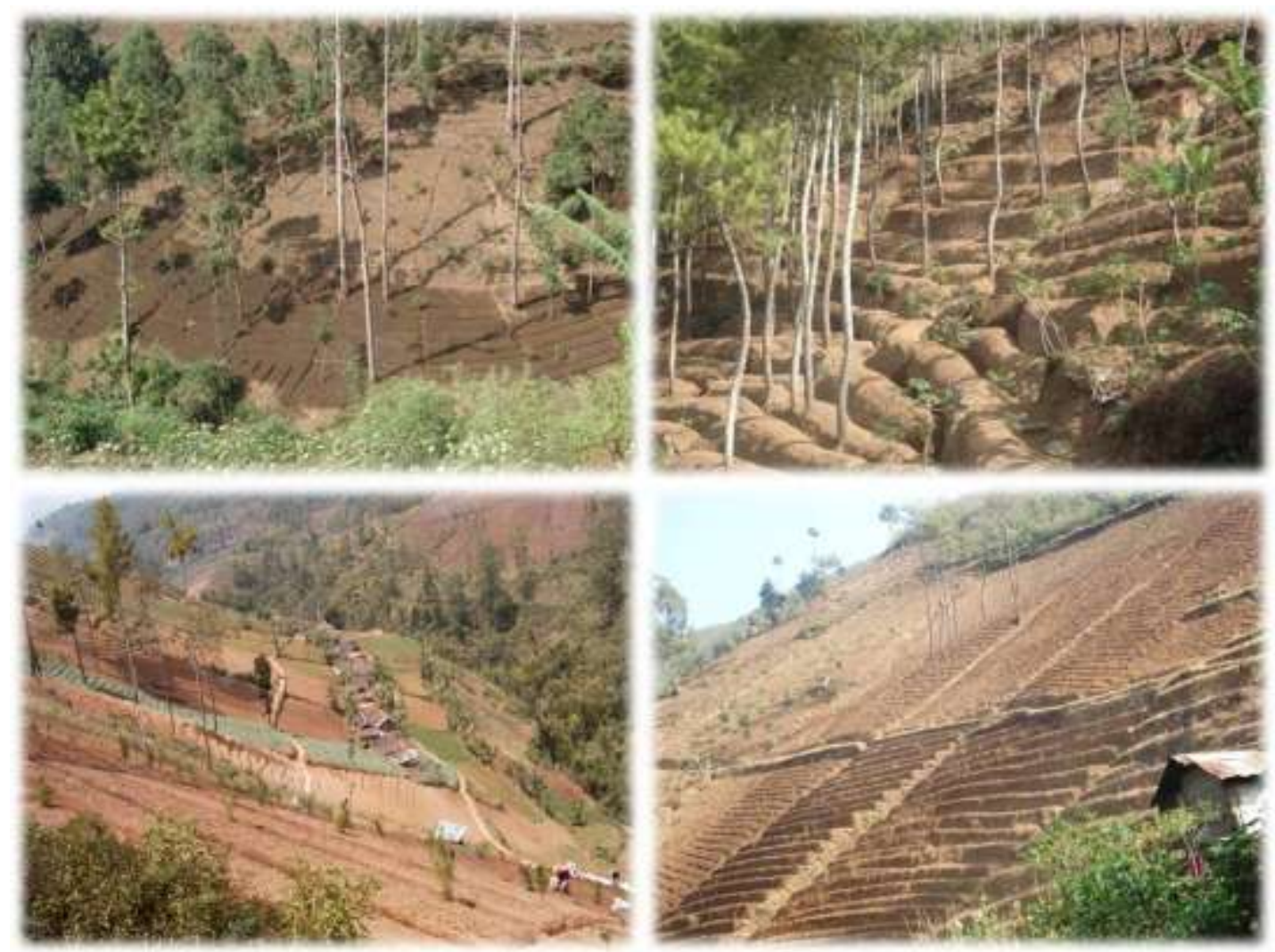

Gambar 4.2. Penanaman sayuran secara intensif diantara tegakan pinus di kawasan hutan produksi dan lindung Perhutani DAS Sumber Brantas.

\subsubsection{Menurunnya debit mata air utama di Kota Batu}

Kawasan hutan lindung di bawah pengelolaan Tahura R. Soerjo dan Perum Perhutani serta hutan produksi dibawah Perum Perhutani yang berada di DAS Sumber Brantas merupakan areal resapan dari 111 buah mata air utama yang ada di wilayah Kota Batu. Deforestasi yang telah terjadi di kawasan hutan lindung maupun di kawasan hutan produksi mengakibatkan perubahan penutupan hutan sehingga memberikan dampak terhadap kurang berfungsinya 
kawasan resapan. Akibatnya, 53 buah mata air pada musim kemarau didapati sudah mati diantaranya sumber Banyuning, sumber Terongbelok, sumber Gemulo, sumber Kasinan, sumber Coban Rais, dan sumber Gunung Biru (Koran Tempo, 29 Nopember 2006).

Sementara itu debit 58 mata air yang masih ada juga menurun. Penelusuran yang dilakukan oleh masyarakat Bumiaji pada tahun 2008 mendapatkan sebuah lagi mata air mati yang terletak di atas sumber Pesanggrahan (Malang Post, 8 Agustus 2008).

Dampak yang lain adalah meningkatnya debit puncak aliran sungai dan tingginya muatan sedimen pada musim penghujan serta menurunnya aliran dasar sungai (base-flow) di musim kemarau. Pengukuran dan pengamatan rutin terhadap debit Kali Brantas di kawasan Kota Batu memang belum ada, tetapi hal-hal tersebut dapat disimpulkan dari berbagai hasil studi dan indikator yang disampaikan oleh berbagai pihak di Kota Batu.

\subsubsection{Banjir dan sedimentasi waduk}

DAS Sumber Brantas yang luasnya 17,3000ha merupakan salah satu anak sungai Kali Brantas dibangian hulu disamping enam Sub-DAS lainnya yang bermuara di Waduk Karangkates. Berdasarkan data dari BP DAS Brantas (2006), ternyata DAS Sumber Brantas memberikan kontribusi sedimentasi tertinggi kedua setelah DAS Amprong. Berdasarkan perkiraan BP DAS Brantas, besarnya sedimen yang masuk sungai dari DAS Sumber Brantas mencapai $86,700 \mathrm{~m}^{3}$ setiap tahun.

Sedimen dari DAS Sumber Brantas berasal dari erosi yang terjadi rata-rata sebesar 143 ton/ha/tahun. Erosi terutama dari kawasan budidaya pertanian (sayuran) dan kawasan hutan Perhutani yang ditanami tanaman semusim. Selain karena faktor lereng yang curam, besarnya kehilangan tanah dipicu oleh sifat tanah yang mudah tererosi (erodibilitas tanah) dan absennya vegetasi penutup tanah khususnya pada awal musim penghujan. 

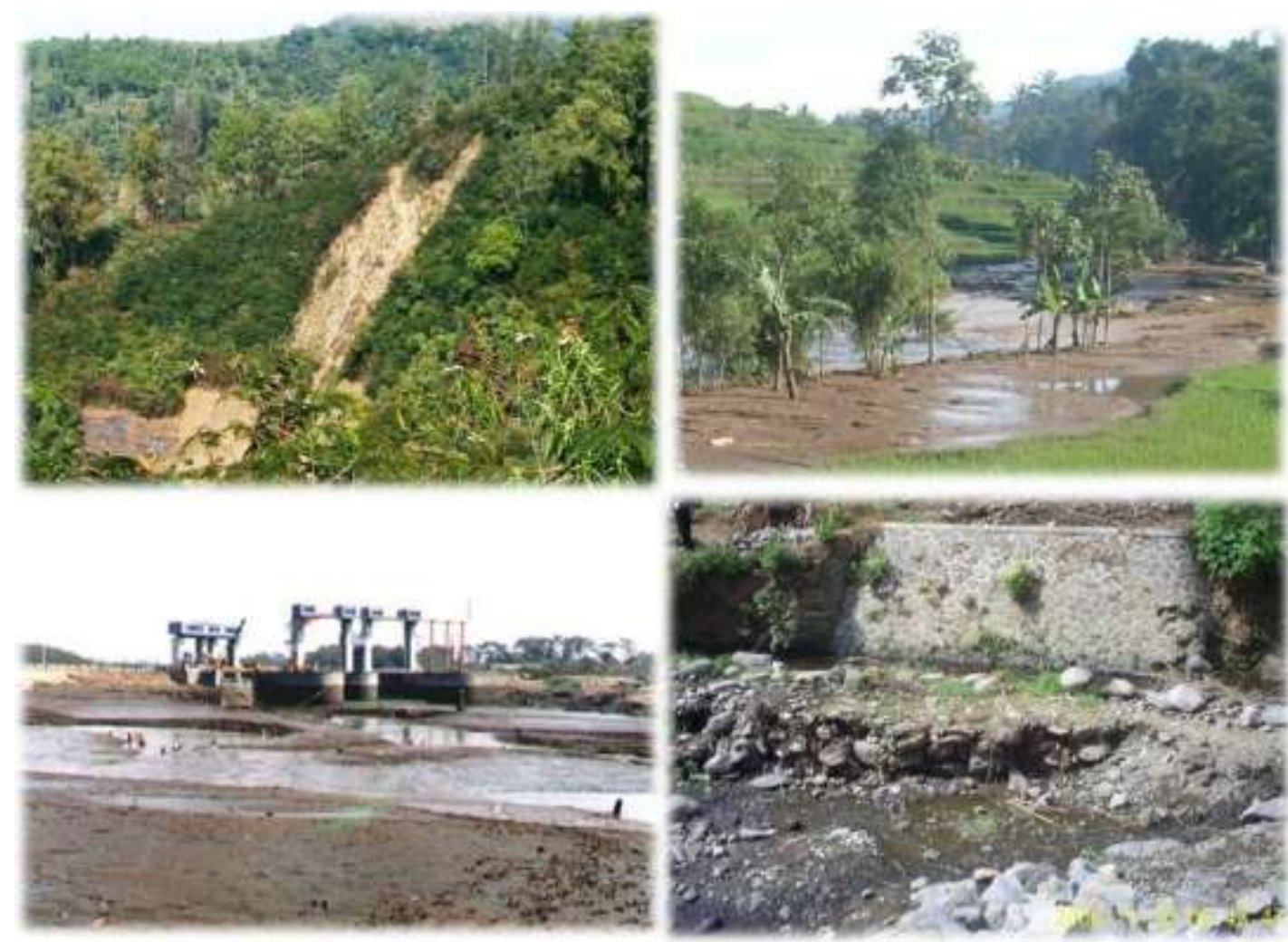

Gambar 4.3. Erosi dan longsor yang terjadi di bagian hulu DAS mengakibatkan pendangkalan sungai dan waduk, serta kerusakan sarana irigasi (check-dam Talun) akibat banjir bandang di Kali Brantas bagian hulu.

Tingginya tingkat erosi di kawasan ini sangat merisaukan Perum Jasa Tirta 1 (PJT) yang sangat berkepentingan dalam menjaga kelestarian umur efektif bendungan di bagian hilir, seperti Bendungan Sengguruh, Sutami, Lahor dan Wlingi serta bangunan-bangunan air lainnya. Berdasarkan studi yang pernah dilakukan oleh PJT 1, umur efektif Bendungan Sutami yang direncanakan selama 100 tahun berkurang menjadi hanya 30 tahun saja akibat pendangkalan waduk. Pada tahun 2003 kapasitas efektif waduk Sengguruh hanya tinggal 42\% dan waduk Sutami tinggal 57\% dibanding saat pembangunan (PJT, 2006). Oleh karena itu PJT memiliki kepentingan untuk ikut serta menjaga kawaaan DAS Sumber Brantas, paling tidak untuk menekan jumlah sedimen yang masuk ke sungai dan memelihara fungsi kawasan resapan beserta sumber-sumber airnya.

\subsubsection{Kontaminasi pestisida dan pupuk dalam aliran air}

Wilayah Kota Batu dan sekitarnya merupakan sentra produksi hortikultura (buah dan sayur) yang memiliki nilai ekonomi cukup tinggi. Usaha tani hortikultura sangat sesuai di kawasan ini, yang memiliki tanah vulkanik subur, cukup air serta suhu udara sejuk pada ketinggian di atas $600 \mathrm{~m}$ dpl. Pertanian yang berbasis tanaman buah dan sayur umumnya dikelola secara sangat intensif, dengan masukan (input) yang sangat tinggi seperti pengolahan tanah, 
penggunaan bibit, pupuk dan pestisida, serta penerapan irigasi. Penggunaan masukan kimia untuk pertanian hortikultura sudah sangat tinggi dosisnya, sehingga jika tidak menggunakannya maka besar kemungkinan produksi menurun bahkan tidak jarang gagal panen karena serangan hama dan penyakit.

Pemakaian bahan kimia dengan takaran yang sudah melebihi batas mengakibatkan terjadinya pencucian sisa pestisida dan pupuk sehingga menyebar mengikuti aliran air menuju air tanah (ground water) atau ke sungai. Selain itu sisa bahan aktif (residu) juga terdapat dalam produk buah atau sayur yang dipanen, sehingga melebihi ambang batas yang diperkenankan.

Pada tahun 2005, terdapat 20 sumber air di kawasan DAS Sumber Brantas yang diduga tercemar oleh pestisida, dan yang paling menderita adalah sumber air Banyuning dan Gemulo (Tempo, 25 Agustus 2005). Sumber-sumber air yang diduga tercemar pestisida ini lokasinya berada di bagian bawah (hilir) dari kawasan pertanian yang didominasi oleh tanaman sayuran. Namun menurut pendapat Kepala Dinas Pertanian Kota Batu, mata air masih aman dari pestisida, tetapi kalau air permukaan kemungkinan besar sudah sedikit tercemar.

Penelitian kualitas air akibat pencemaran pupuk dan pestisida di Kota Batu sampai sejauh ini masih sangat sedikit, sehingga sulit mendapatkan hasil publikasi yang bisa dikutip. Sementara monitoring dan pengukuran terhadap kualitas air belum pernah dilakukan, karena memang sangat mahal. Upaya monitoring kualitas air sungai melalui indikator bentos (vertebrata air) sudah pernah dilakukan tetapi belum bisa dilaksanakan secara rutin.

\subsubsection{Limbah industri, perhotelan dan domestik dalam aliran air}

Wilayah Kota Batu yang terletak di pegunungan dengan hawa sejuk dan pemandangan indah serta dihuni penduduk hampir 200 ribu orang, memiliki kegiatan perkonomian yang sangat aktif di sektor pariwisata, pertanian dan industri pertanian. Kegiatan-kegiatan tersebut menghasilkan berbagai bentuk limbah dalam jumlah cukup banyak. Setiap hari Kota Batu menghasilkan sampah sebanyak $350 \mathrm{~m}^{3}$, namun hanya sekitar $30 \%$ saja yang bisa diangkut ke TPA (tempat pembuangan akhir). Selebihnya, sampah yang tidak tertampung kebanyakan berada di rumah-rumah penduduk berupa sampah domestik. Sebagian kecil dapat dimanfaatkan menjadi kompos dan kerajinan dari sampah rumah tangga (TEMPO Interaktif, 3 September 2008). Sampah ini sangat potensial mencemari sungai yang mengalir di Kota Batu termasuk Kali Brantas, mengingat masyarakat memiliki perilaku suka membuang sampah ke sungai. Upaya sedang dilakukan oleh Pemerintah Kota Batu untuk membangun TPA baru di daerah Tlekung seluas 6 hektar dengan teknologi "sanitary landfiled" supaya bisa menampung dan mengolah sampah kota tersebut.

Selain sampah domestik, sampah pertanian juga sangat berpotensi mencemari sungai, terutama kotoran sapi. Masih banyak peternak sapi perah yang membuang kotoran bercampur 
sisa pakan langsung ke saluran drainasi yang akhirnya masuk ke sungai. Upaya membangun instalasi pengolahan limbah ternak untuk menghasilkan biogas sudah sering disosialisasikan tetapi nampaknya masih belum banyak diminati petani.

Masyarakat di Kelurahan Temas (Kota Batu) sejak tahun 2006 telah mengembangkan pengolahan limbah terpadu dengan sistem wetland, untuk menampung limbah rumah tangga dan limbah industri rumah tangga. Pengelolaan ini dikerjakan oleh Karang Taruna Temas dan LSM Fokal Mesra Kota Batu. Karena dinilai berhasil, Pemerintah Provinsi Jawa Timur mendukung dana pengembangan sistem ini dengan menambah kapasitas (volume) penampungan limbah sehingga bisa menampung limbah dari 500 rumah-tangga, sementara sebelumnya hanya dari 40 rumah-tangga (TEMPO Interaktif, 29 Agustus 2008).

Sumber sampah yang lain adalah dari sektor pariwisata, terutama hotel dan restoran besar. Seharusnya mereka mempunyai instalasi pengolahan limbah sendiri sesuai dengan Undangundang Nomor 18 Tahun 2008 tentang Pengelolaan Sampah, yang mewajibkan perusahaan untuk mengelola sampahnya. Sampah dalam industri hotel dan restoran tak boleh diendapkan lebih dari satu hari. Jika harus mengelola sendiri, manajemen merasa kesulitan karena mereka bukan perusahaan pengolah sampah, sehingga biasanya diserahkan kepada kontraktor.

(TEMPO Interaktif, 28 September 2008).
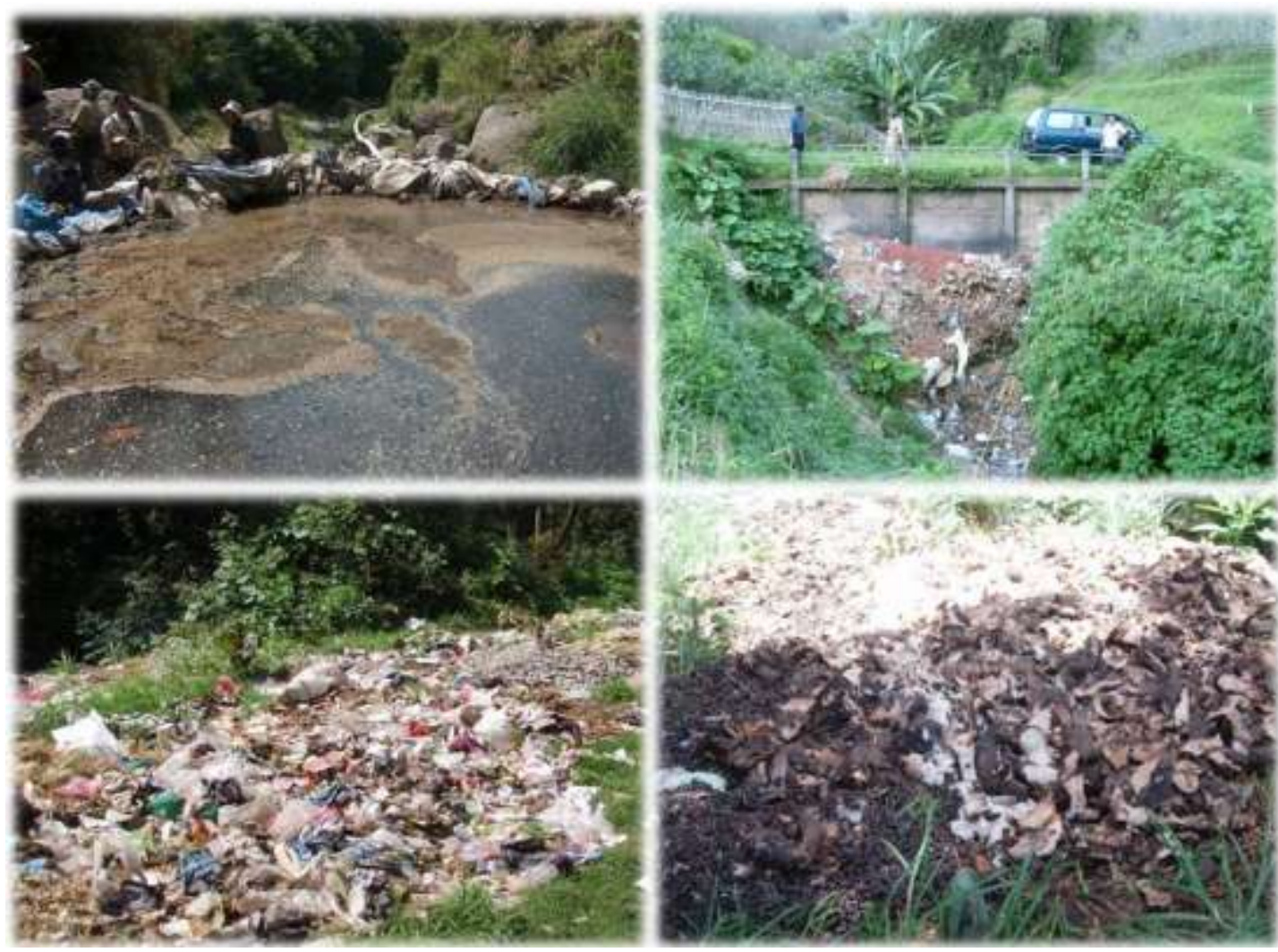

Gambar 4.4. Sampah pertanian, sampah domestik dan sampah industri rumah-tangga dibuang bukan di tempat sampah yang disediakan, berpotensi mencemari mata air dan sungai (kiri atas). 
Kenyataanya, masih banyak limbah rumah tangga dan limbah industri/perusahaan yang dibuang pada tempat pembuangan sampah liar yang berada di dekat pemukiman penduduk dan lokasi pabrik atau bahkan dibuang langsung ke sungai (Gambar 3.4.). Untuk mengatasi masalah pencemaran sampah ini Pemerintah Kota Batu telah merencanakan membangun instalasi pengolahan limbah terpadu untuk mengolah limbah domestik dan industri. Badan Perencanaan Pembangunan Daerah (Bappeda) Kota Batu sudah mulai melakukan kajian dan penelitian.

\subsubsection{Konflik stakeholder sebagai akibat ketidak teraturan pemanfaatan sumber air dan aliran sungai}

Konflik atau potensi konflik yang disebabkan oleh rebutan penguasaan air sudah mulai dirasakan di Kota Batu. Beberapa tahun yang lalu telah terjadi tarik ulur antara Pemkot Batu dan Pemkot Malang (PDAM) terkait dengan pembagian dana atas penggunaan air dari Kota Batu oleh PDAM Kota Malang.

Dalam penelusuran bersama masyarakat ditemukan adanya beberapa instansi dan perusahaan besar yang mengambil air langsung dari mata air di kawasan hutan (Tahura dan Perhutani). Berbagai pihak merasa tidak pernah memberikan ijin untuk pengambilan air dan terjadi saling lempar tanggung-jawab atas terjadinya kasus ini.

Selain instalasi pengambilan air yang besar, di lapangan juga ditemukan banyak sekali instalasi penyedotan air dalam skala kecil dengan pompa mesin untuk keperluan irigasi lahanlahan disekitarnya.

Persoalan timbul pada musim kemarau ketika debit air Kali Brantas sangat kecil, kebutuhan sehari-hari untuk domestik dan lain-lainnya ternyata tidak terpenuhi, maka persoalan penyedotan air di hulu menjadi isu yang menimbulkan potensi konflik. 

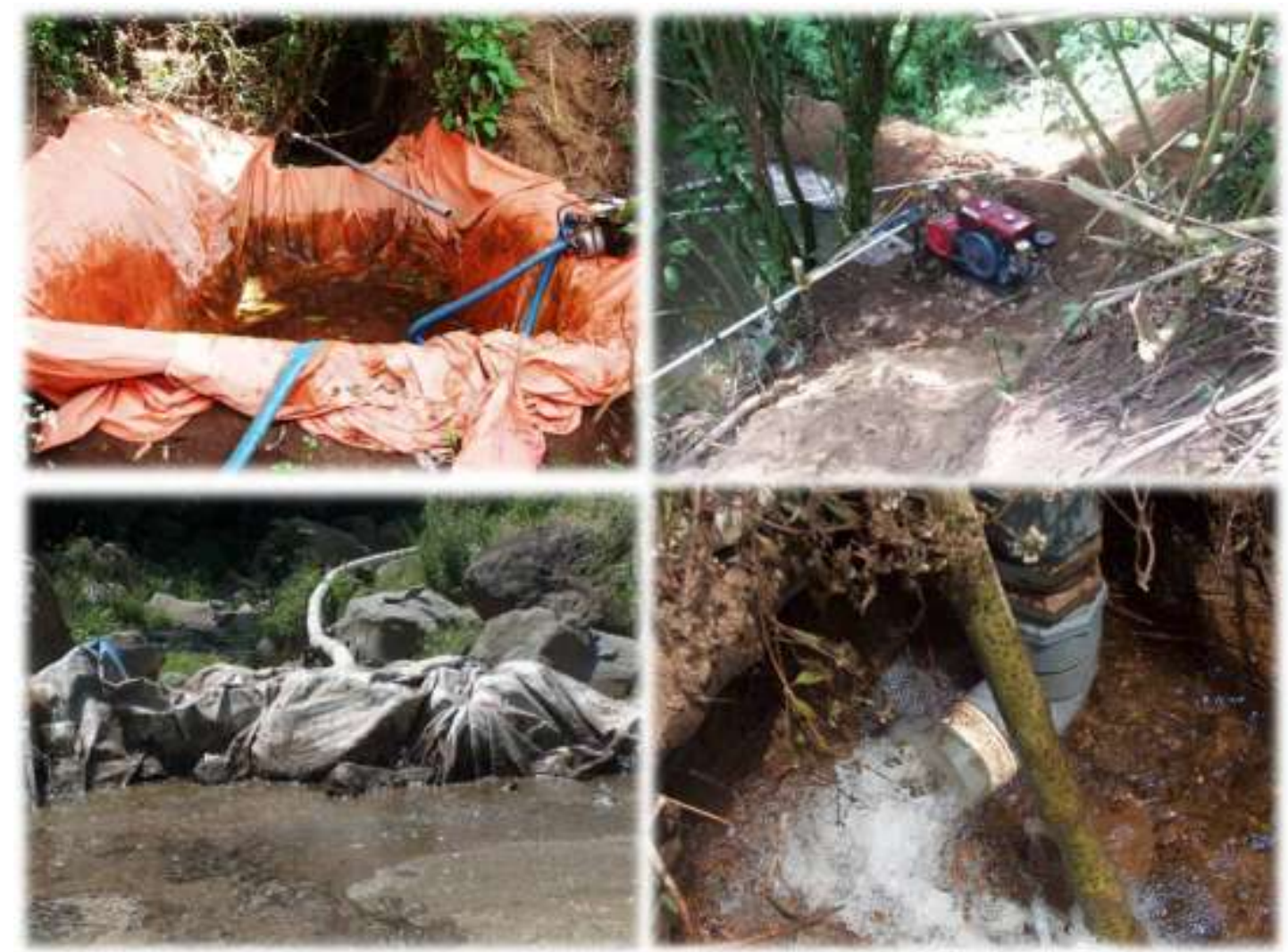

Gambar 4.5. Pompa air "berserakan" secara tersembunyi maupun terang-terangan di sekitar sumber air di DAS Sumber Brantas, untuk menyedot air secara "ilegal" digunakan untuk irigasi dan berbagai keperluan lainnya.

\subsubsection{Berkembangnya kawasan pemukiman dan industri di kawasan resapan}

Kawasan DAS Sumber Brantas secara tradisional merupakan daerah resapan yang sangat potensial bagi kesetimbangan hidrologi di DAS Brantas. Namun, fungsi tersebut akhir-akhir ini menjadi sangat terganggu akibat perkembangan penutupan lahan yang tidak terkendali. Gangguan terbesar adalah penebangan hutan baik ilegal maupun legal, mengakibatkan semakin luasnya tanah terbuka yang menyebabkan semakin besarnya limpasan permukaan dan erosi, akibat menurunnya laju infiltrasi.

Limpasan permukaan semakin besar dengan berkurangnya kawasan resapan akibat tertutup oleh bangunan baik perluasan pemukiman, pembangunan hotel, industri, dsb. Salah satu contoh pembangunan perusahaan jamur yang berada di kawasan Sumber Brantas seluas beberapa hektar (Gambar 4.1). 


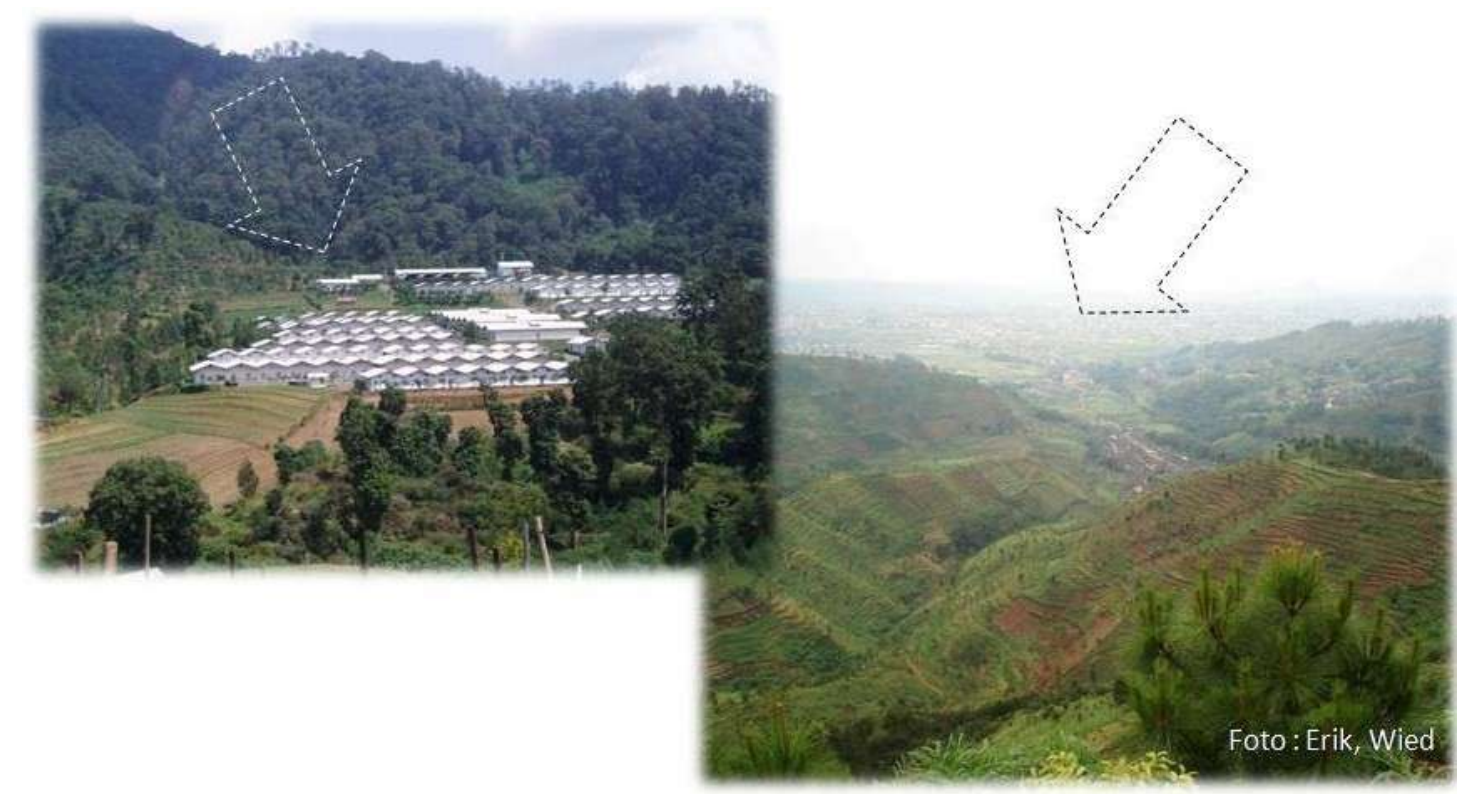

Gambar 4.6. Kondisi tutupan lahan di kawasan resapan DAS Sumber Brantas terbuka di hulu dan pemukiman di tengah (foto kanan), dan bangunan untuk industri/perusahaan di bagian hulu yang menutupi permukaan tanah sebagai kawasan resapan (foto kiri)

\subsection{Evaluasi Pengalaman Stakeholder dalam membangun integrasi komunikasi dalam Menjalankan Jasa Lingkungan}

Kegiatan fasilitasi Fokal Mesra, LMDH, kegiatan GNKPA (perencanaan DAS Mikro) dan GN-RHL untuk karakterisasi wilayah DAS dan diagnosis isu utama dan masalahnya terkait dengan fungsi DAS dan perikehidupan (termasuk sumber air minum) telah dilakukan dengan baik, walaupun dengan pendekatan yang berbeda (Tabel 5). Fokal Mesra melalui perencaan partisipatif untuk perbaikan peri-kehidupan masyarakat dengan analisis keterkaitan ekosistem hutan, lahan budidaya, sungai/sumber air, dan pemukiman memberikan informasi yang komperhensif untuk menyusun rencana aksi. Demikian pula LMDH dengan pendekatan pemetaan secara partisipatif dan GN-KPA (perencanaan DAS Mikro) dan GN-RHL dengan pedekatan Partisipatory Rapid Aprassial (PRA). Kegiatan GIRAB cukup memadai dengan pendekatan penelusuran transek DAS melalui kegiatan penelusuran sungai, namun pemahaman akar masalah dari isu yang ada belum teranalisis dengan baik.

Penilaian Bentang Lahan, kemiringan, penggunaan lahan dan zonasi vegetasi, toposekuen tanah dari punggung bukit sampai ke lembah sungai dalam kegiatan Fokal Mesra dilakukan secara partisipatif melalui kegiatan transek wilayah desa. Kegiatan LMDH dilakukan melalui kegiatan pemetaan secara partisipatif di masing-masing petak lahan Perhutani. Kedua kegiatan tersebut belum banyak memanfaatkan kaidah-kaidah ilmiah. Sementara GN-KPA (perencanaan DAS Mikro) dan GN-RHL dilakukan melalui upaya penggabungan antara 
kaidah-kaidah ilmiah dan partisipasi masyarakat. Kegiatan GIRAB hanya dilakukan observasi oleh stakeholder.

Pemahaman aliran air dan kosekuensi aliran lateral dilakukan dengan baik dalam kegiatan GN-KPA (perencanaan DAS Mikro) dan GN-RHL melalui analisis perkiraan limpasan permukaan, erosi dengan pendekatan model dan aliran bawah tanah dengan geolistrik. Untuk kegiatan Fokal Mesra dilakukan dengan inventarisasi pengetahuan lokal. Untuk kegiatan PHBM dan GIRAB hanya dilakukan melalui observasi sesaat.

Pencirian sistem penggunaan lahan terkait dengan hasil, tenaga kerja dan kebutuhan masukan biaya produksi/keuntungan dan dampak-dampaknya terhadap aliran air (evapotranspirasi, dampak pada pemadatan tanah, penutupan lahan) dilakukan dengan baik dalam kegiatan Fokal Mesra melalui sekolah lapangan dan GN-KPA (perencanaan DAS Mikro) dan GNRHL melalui pendekatan PRA. Untuk kegiatan PHBM dan GIRAB dilakukan melalui pemahaman empiris berdasarkan pengalaman-pengalaman setempat dan diangkat menjadi isu-isu strategis.

Pencirian mosaik bentang lahan dalam pandangan terpisah-pisah-terpadu, dan kosekuensinya terhadap mempertemukan fungsi produksi dan fungsi lingkungan dilakukan dengan baik dalam perencaan DAS Mikro melalui pendekatan pemetaan bentang lahan yang dikonfirmasikan dengan indepth interview dengan masyarakat. Untuk kegiatan Fokal Mesra dan PHBM dilakukan melalui pemahaman empiris berdasarkan diskusi-diskusi informal dan pertemuan-pertemuan stakeholder dan pengalaman-pengalaman setempat dan diangkat menjadi issu-issu strategis. Untuk kegiatan GIRAB kurang mendapatkan perhatian.

Pemahaman trade-offs antara fungsi agronomis relatif (RAF) dan fungsi lingkungan relative (REF), sebagai contoh dalam bentuk jumlah penduduk yang kecukupan pendapatan per $\mathrm{km}^{2}$ sebagai RAF dan jumlah penduduk dengan kecukupan air bersih hanya mendapat perhatian dalam kegiatan LMDH untuk memperjelas bagi hasil antara LMDH, Perum Perhutani dan Pemkot Batu melalui kesepakatan-kesepakatan bertahap, walaupun kesepakatan-kesepatan tersebut belum didokumentasikan dengan baik.

Mosaik bentang lahan dalam kontek aliran air dan "externalities" untuk pembuatan keputusan di lahan petani; keberadaan aturan dan insentif ('carrots and sticks') di tingkat masyarakat dan pemerintah; apakah moasik bentang lahan yang ada konfigurasinya stabil untuk memenuhi sebuah kebutuhan di kegiatan Fokal Mesra, LMDH dan GIRAB dilakukan baik dalam kesepakatan-kesepakatan secara partisipatif, pembuatan PERDES, penggalangan dukungan dari stakeholder lain. Untuk kegiatan GN-KPA (perencanaan DAS Mikro) dan GNRHL belum jelas kelanjutan kegiatan karena kegiatan ini dirancang berdasarkan keproyekan oleh BBWS Kali Brantas dan BP DAS Brantas. 
Analisis praktek pola dan penggunaan lahan yang ada berdasarkan prespektif stakeholder (termasuk gender dan pemerataan) cukup baik dilakukan dalam kegiatan Fokal Mesra dan LMDH, namun isu-isu yang diangkat belum jelas menyelesaikan masalah yang ada.

Pemahaman masalah yang ada dan konflik pada tingkat pengetahuan lokal, kebijakan dan ilmiah: sebagai tahapan dalam negosiasi dilakukan dengan baik dalam kegiatan Fokal Mesra, LMDH dan GIRAB melalui pendekatan empiris pengalaman-pengalaman jangka panjang yang diakukan oleh masyarat setempat secara partisipatif, namun dukungan subtantif tentang pemahaman fungsi DAS yang sehat masih bias.

Kelanjutan kesepakaran negosiasi, diikuti dengan kegiatan monitoring dan dampaknya terhadap layanan lingkungan dan perikehidupan masyarakat dilakukan dengan baik oleh Fokal Mesra dan LMDH dengan terus adanya interaksi yang positif secara organik stakeholder. Untuk Perencanaan DAS Mikro hingga saat ini komitmen dari BBWS Kali Brantas maupun BP DAS Brantas untuk merealisasi rencana yang dibuat belum jelas. Untuk kegiatan GIRAB sangat ditentukan oleh kepeloporan Camat yang walaupun telah mendapatkan dukungan dengan baik stakeholder di wilayah kecamatan tersebut, namun intrik-intrik politik yang berkembang dapat mengganggu kelancaran kegiatan tersebut.

Tabel 4.3. Evaluasi Pelaksanaan Membangun Komunikasi dalam Menjalankan Jasa Lingkungan di DAS Sumber Brantas

\begin{tabular}{|c|c|c|c|c|c|c|}
\hline \multirow{2}{*}{ Tahap } & \multirow{2}{*}{ Dukungan negosiasi DAS } & \multicolumn{5}{|c|}{$\begin{array}{c}\text { Macam integrasi stakeholder pengambil keputusan } \\
\text { dengan masyarakat }\end{array}$} \\
\hline & & $\begin{array}{l}\text { Fokal } \\
\text { Mesra }\end{array}$ & LMDH & GN-KPA & GIRAB & GN-RHL \\
\hline 1 & Karakterisasi dan diagnosis DAS. & $\mathrm{B}$ & $\mathrm{B}$ & $\mathrm{B}$ & C & C \\
\hline 2 & Penilaian Bentang Lahan. & C & C & $\mathrm{B}$ & $\mathrm{K}$ & $\mathrm{C}$ \\
\hline 3 & Pemahaman aliran air & C & $\mathrm{K}$ & $\mathrm{B}$ & $\mathrm{K}$ & $\mathrm{K}$ \\
\hline 4 & Pencirian system penggunaan lahan & $\mathrm{B}$ & $\mathrm{C}$ & $\mathrm{B}$ & $\mathrm{C}$ & $\mathrm{B}$ \\
\hline 5 & $\begin{array}{l}\text { Pencirian mosaik mempertemukan } \\
\text { fungsi produksi dan fungsi lingkungan. }\end{array}$ & $\mathrm{C}$ & C & B & $\mathrm{K}$ & $\mathrm{C}$ \\
\hline 6 & Pemahaman tradeoffs & $\mathrm{K}$ & C & $\mathrm{K}$ & $\mathrm{K}$ & $\mathrm{K}$ \\
\hline 7 & $\begin{array}{l}\text { Mosaik bentang lahan dan; } \\
\text { keberadaan aturan dan insentif }\end{array}$ & C & C & $\mathrm{K}$ & C & C \\
\hline 8 & $\begin{array}{l}\text { Analisis praktek pola dan penggunaan } \\
\text { lahan berdasarkan prespektif } \\
\text { stakeholder. }\end{array}$ & $\mathrm{C}$ & $\mathrm{C}$ & $\mathrm{K}$ & $\mathrm{K}$ & C \\
\hline 9 & $\begin{array}{l}\text { Pemahaman pengetahuan lokal, } \\
\text { kebijakan dan ilmiah: }\end{array}$ & B & B & C & $B$ & C \\
\hline 10 & Kelanjutan kesepakaran negosiasi, & $\mathrm{B}$ & $\mathrm{B}$ & $\mathrm{K}$ & $\mathrm{C}$ & $\mathrm{C}$ \\
\hline
\end{tabular}




\section{Modellers Ecological Knowledge (MEK)}

\subsection{Metode}

\subsubsection{Konsep Dasar Fungsi Hidrologi DAS}

Pada dasarnya terdapat tiga fungsi penting daerah aliran sungai sehubungan dengan kondisi hidrologi DAS, yaitu:

1. DAS sebagai area penampung air hujan.

2. DAS sebagai penyimpan air dalam jumlah dan waktu yang bervariasi dan berbeda-beda

3. DAS sebagai sistem yang akan melepaskan air baik dalam bentuk aliran permukaan maupun aliran dalam tanah.

Kunci utama penilaian kualitas suatu daerah aliran sungai terletak pada volume dan waktu aliran air yang dihasilkan oleh sistem DAS. Waktu serta volume aliran air tersebut sangat dipengaruhi oleh interaksi antara air hujan yang jatuh dengan kondisi penutupan lahan dan sifat-sifat tanah yang ada. Beberapa proses yang terjadi sehubungan dengan interaksi tersebut adalah:

1. Intersepsi air hujan oleh vegetasi. Komposisi vegetasi yang bervariasi pada suatu bentang lahan berpengaruh terhadap waktu jatuhnya air hujan di atas permukaan tanah.

2. Aliran permukaan sesaat setelah terjadinya hujan (surface quick flow). Aliran permukaan ini merupakan air yang tidak dapat terinfiltrasi ke dalam tanah dan akan mengalir menuju saluran-saluran drainase yang ada dalam sistem DAS.

3. Air hujan yang terinfiltrasi dalam tanah yang telah berada dalam kapasitas lapang akan mengalir ke dalam sistem sungai terdekat (soil quick flow).

4. Meningkatnya kapasitas infiltrasi tanah karena terserapnya air tanah oleh akar melalui proses transpirasi dan evaporasi.

5. Aliran air secara perlahan dari air tanah (groundwater stock) menuju saluran-saluran drainase dan sungai. 


\subsubsection{Struktur Model GenRiver}

GenRiver merupakan model yang dikembangkan berdasarkan preses hidrologi yang terjadi dalam level plot yang kemudian dikembangkan dalam level catchment, berdasarkan pada perhitungan-perhitungan empiris. Model ini dapat dipergunakan sebagai alat untuk memahami perubahan karakteristik aliran sungai terhadap perubahan penggunaan lahan yang terjadi pada tingkat plot, subcatchment dan catchment. Inti dari model ini adalah kondisi water ballance pada level plot yang dipengaruhi oleh curah hujan, tipe penutupan lahan dan sifat-sifat tanahnya. Pada level plot ini akan terjadi proses-proses aliran air seperti aliran permukaan sesaat setelah terjadinya hujan (surface quick flow), aliran air dalam tanah (soil quick flow) sehari setelah terjadinya hujan dan aliran air dari groundwater stock (base flow) yang dilepaskan perlahan ke saluran-saluran drainase.

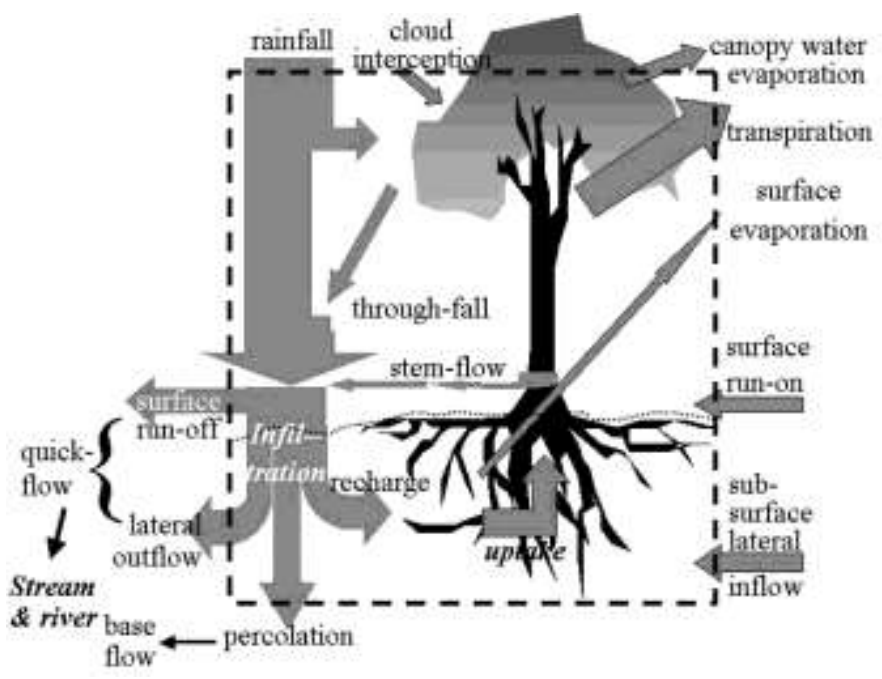

Gambar 5.1. Water ballance pada plot level yang merupakan inti dari model GenRiver

Input data untuk GenRiver disesuaikan dengan ketersediaan data yang berasal dari data sekunder (contoh: data timeseries hujan, suhu dan debit harian). Model GenRiver menggunakan program Stella yang memungkinkan dilakukannya modifikasi struktur model yang diperlukan oleh pengguna. Selain program Stella yang berbentuk file stm, dalam pengoperasiannya model ini menggunakan file excel yang didalamnya memuat data-data yang dapat dihubungkan (linked) dengan program Stella. Terdapat enam (6) sheet utama dalam program excel GenRiver yang memuat data-data yang akan diproses dalam running program GenRiver, yaitu sheet data hujan, debit, landcover, subcatment, evapotranspirasi dan sifat tanah. Dalam program Stella untuk model GenRiver, terdapat tiga menu utama yaitu menu input data (to input menu), menu untuk running dan output (run and output) dan menu yang menunjukkan struktur model GenRiver (model structure). 


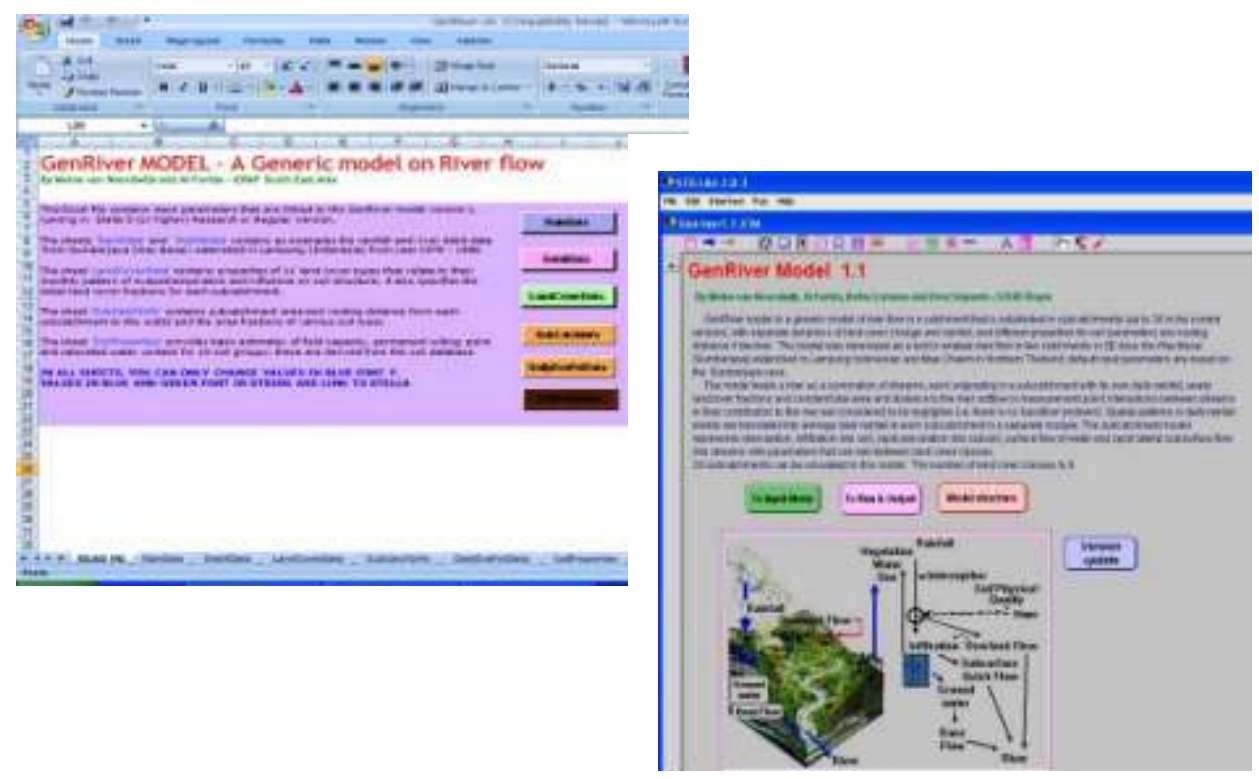

Gambar 5.2. Tampilan (layout) file GenRiver excel dan stella

Sementara itu, indikator-indikator kuantitatif dari fungsi DAS dalam merespon perubahan penggunaan lahan terhadap debit sungai yang dihasilkan ditunjukkan pada tabel berikut.

Tabel 5.1. Indikator kuantitatif fungsi DAS

\begin{tabular}{lll}
\hline \multicolumn{1}{c}{ Kriteria } & \\
\hline 1. Transmisi Air & Total debit sungai per unit hujan (TWY) \\
\hline 2. Penyangga pada puncak & a. Buffering indicator (BI). Indikator penyangga. \\
& bejadian hujan & b. Relative buffering indicator (RBI). Indikator penyangga terhadap total debit \\
& c. Buffering peak event (BPE) Indikator penyangga puncak kejadian hujan \\
& d. Total maksimum debit terhadap rata-rata curah hujan bulanan \\
& e. Total aliran air permukaan (surface quick flow ${ }^{2}$ ) terhadap debit total \\
& f. Total aliran air tanah (soil quick flow ${ }^{3}$ ) terhadap debit total \\
\hline 3. Pelepasan air secara & a. Total minimum debit terhadap rata-rata curah hujan bulanan \\
bertahap & b. Total aliran lambat (slow flow ${ }^{4}$ ) total debit \\
\hline
\end{tabular}

Keterangan :

2. Surface quick flow = aliran cepat permukaan = aliran permukaan pada saat kejadian hujan

3. Soil quick flow $=$ aliran cepat air $\operatorname{tanah}=$ aliran air dalam lapisan tanah setelah satu hari kejadian hujan

4. Slow flow = aliran lambat = aliran air dalam lapisan tanah setelah lebih dari satu hari kejadian hujan 


\subsubsection{Tahapan Kegiatan dalam MEK}

Tahapan-tahapan dalam kegiatan MEK disajikan pada tabel di bawah ini.

Tabel 5.2. Tahapan kegiatan dalam MEK

\begin{tabular}{|c|c|c|c|}
\hline Tahap & Kegiatan & Metode & Outputs \\
\hline 1 & $\begin{array}{l}\text { Review dan studi literatur tentang kondisi } \\
\text { hidrologi, landscape, geologi, iklim dan } \\
\text { sistem pengelalaan DAS Sumber Brantas }\end{array}$ & $\begin{array}{l}\text { Pengumpulan data dan } \\
\text { informasi dari sumber- } \\
\text { sumber terdahulu }\end{array}$ & $\begin{array}{l}\text { Kondisi pengelolaan air, } \\
\text { kondisi umum di DAS } \\
\text { Sumber Brantas }\end{array}$ \\
\hline 2 & $\begin{array}{l}\text { Penentuan dan pengumpulan parameter- } \\
\text { parameter iklim dan hidrologi serta } \\
\text { pengumpulan data-data iklim lainnya }\end{array}$ & Analisis data time series & $\begin{array}{l}\text { Deskripsi kondisi iklim dan } \\
\text { hidrolgi DAS Sumber } \\
\text { Brantas }\end{array}$ \\
\hline 3 & $\begin{array}{l}\text { Parametirisasi kondisi landuse / } \\
\text { landcover dan pembagian sub catchment }\end{array}$ & $\begin{array}{l}\text { Pemrosesan dan } \\
\text { analisis data geospasial }\end{array}$ & $\begin{array}{l}\text { Database untuk data-data } \\
\text { spasial dan indikator model }\end{array}$ \\
\hline 4 & $\begin{array}{l}\text { Parameterisasi untuk data tanah (jenis } \\
\text { tanah dan kedalaman) }\end{array}$ & $\begin{array}{l}\text { Pengumpulan data dari } \\
\text { penelitian-penelitian } \\
\text { yang sedang berjalan } \\
\text { dan terdahulu }\end{array}$ & Indikator-indikator model \\
\hline 5 & $\begin{array}{l}\text { Parameterisasi dan analisa kondisi } \\
\text { landuse aktual dan landuse skenario }\end{array}$ & Model GenRiver & $\begin{array}{l}\text { Dampak hidrologi dari } \\
\text { perubahan penggunaan } \\
\text { lahan di DAS Sumber } \\
\text { Brantas }\end{array}$ \\
\hline
\end{tabular}

Sementara itu, detail kegiatan dari setiap tahapan tersebut dijelaskan sebagai berikut.

Tahap 1. Review dan studi literatur tentang kondisi hidrologi, landscape, geologi, iklim dan sistem pengelalaan DAS Sumber Brantas

Pada tahap ini terdapat dua kegiatan. Kegiatan pertama adalah pengumpulan data sekunder dan informasi tentang studi yang berhubungan dengan kondisi hidrologi, bentang lahan (landscape), geologi, dan iklim di DAS Sumber Sumber Brantas. Data-data yang dimaksud dapat berupa laporan, artikel atau dokumentasi-dokumentasi lainnya. Kegiatan kedua adalah konsultasi dengan pihak-pihak terkait baik institusi maupun narasumber yang mempunyai kegiatan di lokasi studi yang berhubungan dengan kondisi hidrologi, pengelolaan DAS, dan topik terkait lainnya.

Metode yang dipergunakan dalam tahap ini adalah pengumpulan data dan informasi dari sumber-sumber terdahulu.

Output yang didapatkan dari tahap pertama ini adalah informasi tentang kondisi pengelolaan air, serta kondisi umum di wilayah studi. 


\section{Tahap 2. Parameterisasi kondisi iklim dan hidrologi serta data-data lainnya}

Data iklim dan hidrologi yang telah terkumpul dipergunakan untuk memvalidasi model GenRiver dan menjalankan simulasi kondisi aktual serta skenario yang diajukan. Keseluruhan kegiatan dalam tahap kedua ini dalam hubungannya dengan pengumpulan dan analisa data iklim dan hidrologi dijelaskan sebagai berikut :

- Pengumpulan data hujan dan data debit sungai selama 10 tahun

- Pengumpulan data evapotranspirasi harian selama 10 tahun

- Pengumpulan data hidrologi lainnya

- Analisa konsistensi data

Metode yang dipergunakan dalam tahap ini adalah dengan melakukan analisa data time series. Output yang dihasilkan berupa deskripsi kondisi iklim dan hidrologi DAS Sumber Brantas.

\section{Tahap 3. Parameterisasi landuse / landcover dan batas subcatchment}

Langkah-langkah yang dilakukan pada tahap ini adalah:

- Pengumpulan peta-peta maupun image seperti peta batas administrasi, peta geologi, peta jenis tanah, dan image satelit.

- Pengadaan data Digital Elevation Model (DEM)

- Pemrosesan peta (klasifikasi landuse dan penentuan jaringan sungai / subcatchment).

Metode yang dipergunakan dalam tahap ini adalah pemrosesan dan analisa data geospasial.

Output yang dihasilkan berupa database untuk data-data geospasial dan indikator model GenRiver.

\section{Tahap 4. Parameterisasi untuk data tanah (jenis dan kedalaman tanah)}

- Pengumpulan dan analisa data-data sifat tanah dari studi terdahulu khususnya data jenis tanah dan kedalaman tanah.

- Mengaplikasikan fungsi pedotransfer dari bermacam jenis tanah di lokasi studi sebagai parameter dalam model GenRiver.

Metode yang dipergunakan dalam tahap ini adalah pengumpulan data dari penelitianpenelitian yang sedang berjalan dan penelitian terdahulu.

Output yang dihasilkan berupa indikator-indikator untuk model GenRiver. 


\section{Tahap 5. Parameterisasi dan Analisa Data Kondisi Landuse Aktual dan Skenario}

Model GenRiver dikembangkan oleh ICRAF SEA sebagai suatu perangkat untuk menganalisa debit aliran sungai pada suatu Daerah Aliran Sungai (DAS) sebagai konsekuensi terhadap kondisi landuse yang ada di dalamnya. DAS terbagi dalam subcatchment (subDAS) yang masing-masing mempunyai kondisi landuse / landcover, jenis tanah, sifat-sifat fisik tanah, hujan, dan panjang aliran sungai yang berbeda-beda. Dalam model GenRiver, aliran sungai merupakan integrasi dari seluruh aliran anak sungai yang berada pada tiap subcatchment yang mempunyai karakteristik yang berbeda seperti yang dijelaskan sebelumnya. Model ini dikembangkan berdasarkan data-data yang didapatkan dari DAS Way Besai, Lampung Indonesia dan DAS Mae Chaem di Thailand Utara.

Data-data yang diperlukan untuk mengaplikasikan model GenRiver antara lain adalah :

A. Data Iklim

- Hujan

Data hujan diambil dari 6 stasiun data hujan di wilayah DAS Sumber Brantas. Keenam stasiun hujan ditentukan berdasarkan metode poligon thiesen. Keenam stasiun hujan tersebut adalah stasiun Kedungrejo, Ngaglik, Pacet, Ciliwung, Tlekung dan Pujon. Keseluruhan data hujan yang didapatkan dari tiap stasiun tersebut diambil dalam bentuk data timeseries selama 10 tahun dari tahun 1998 sampai dengan tahun 2007.

- Intensitas Hujan

Data intensitas hujan didapatkan dari data jumlah hujan dan waktu atau durasi kejadian hujan.

- Potensial Evaporasi

Data potensial evapotranspirasi diperoleh melalui persamaan Thornwaite. Sementara itu, data suhu harian yang dipergunakan dalam perhitungan tersebut mempergunakan data suhu harian selama kurun waktu 10 tahun dari tahun 1998 sampai dengan 2007 yang diperoleh dari Badan Meteorologi dan Geofisika (BMG) stasiun klimatologi Karangploso Malang.

$$
\begin{array}{ll}
\mathrm{PET} & =1,6[(10 . \mathrm{T}) / \mathrm{I}]^{\mathrm{a}} \\
\mathrm{I} & =\sum_{\mathrm{i}=1}^{12}\left[\left(\frac{\mathrm{T}}{5}\right)\right]^{1,5}
\end{array}
$$

Dimana :

PET = Evapotranspirasi potensial $(\mathrm{mm})$

$\mathrm{T}=$ Suhu rata-rata bulanan $(\mathrm{oC})$ 


$$
\begin{array}{lll}
\mathrm{I} & = & \text { Indeks panas tahunan } \\
\mathrm{a} & = & 675 \cdot 10^{-9} \mathrm{I}^{3}-771 \cdot 10^{-7} \mathrm{I}^{2}+1792 \cdot 10^{-5} \mathrm{I}+0,49239
\end{array}
$$

B. Kondisi Landform dan Jaringan Sungai

Kondisi landform dan jaringan aliran sungai di DAS Sumber Brantas didapatkan dari peta DEM. Peta ini pada dasarnya memperlihatkan perbedaan elevasi (ketinggian tempat) pada setiap subcatchment. Pada akhirnya dengan perbedaan ketinggian ini, diperoleh batas-batas subcatchment.

C. Tanah

Data tanah yang diperlukan untuk input data dalam model ini adalah:

- Rata-rata kedalaman tanah (batas olah perkembangan akar).

- Tekstur tanah (atau jenis tanah) sebagai input fungsi pedotransfer untuk mengestimasi kurva retensi air tanah (saturation, field capacity, dan wilting point).

- Estimasi berat isi tanah pada berbagai kondisi penggunaan tanah khususnya untuk pertanian, untuk mengestimasi konduktivitas hidrolik jenuh dan potensial infiltrasi.

D. Vegetasi dan Penutupan Lahan

Data tentang fraksi vegetasi dan landcover diperoleh dari analisis citra satelit. Detail selengkapnnya disajikan pada bab 2 .

\section{E. Data Debit Prediksi}

Dalam simulasi model GenRiver untuk kondisi DAS Sumber Brantas ini, debit sungai dalam bentuk time series tidak dapat disajikan. Hal ini disebabkan karena pengukuran debit aktual terletak jauh di bagian hilir (diluar DAS Sumber Brantas) dimana representasi wilayah yang terukur debitnya meliputi wilayah DAS Amprong, Bango, dan DAS Sumber Brantas itu sendiri. Oleh karena itu, dalam studi yang khusus dilakukan di DAS Sumber Brantas, data debit prediksi dalam jangka waktu 10 tahun akan dipergunakan untuk menjelaskan kondisi hidrologi di wilayah ini.

\subsubsection{Validasi Model GenRiver}

Validasi model GenRiver dalam studi ini dilakukan untuk menguji apakah model GenRiver dapat dipergunakan untuk mengetahui kondisi hidrologi di Sub DAS Sumber Brantas. Validasi sendiri menurut Hoover dan Perry (1989) merupakan proses penentuan apakah model, sebagai konseptualisasi atau abstraksi, merupakan representasi berarti dan akurat dari sistem nyata. Terdapat banyak macam metode validasi. Namun demikian, dalam konteks studi yang dilakukan, validasi model GenRiver dilakukan dengan metode perbandingan output 
simulasi dengan sistem nyata. Membandingkan output ukuran kinerja model simulasi dengan ukuran kinerja yang sesuai dari sistem nyata merupakan metode yang paling sesuai untuk melakukan validasi metode simulasi. Uji T, uji F maupun metode nonparametrik lainnya seperti uji ChiSquare dan Kolmogorov Smirnov dapat digunakan untuk menguji kesamaan ragam sistem nyata dengan model simulasi.

Validasi model GenRiver dilakukan pada tiga Sub DAS berbeda dimana salah satunya adalah sub DAS Sumber Brantas. Dua sub DAS yang dimaksud adalah sub DAS Bango dan Amprong. Sub DAS Bango dan Amprong terletak di wilayah Kabupaten Malang. Validasi model dilakukan dengan menghitung nilai efisiensi model dengan menggunakan persamaan Nush and Sutcliffe. Persamaan Nash and Sutcliffe disajikan sebagai berikut.

$$
\mathrm{NSE}=1-\left[\frac{\sum_{i=1}^{n}\left(Y_{i}^{o b s}-Y_{i}^{\text {sim }}\right)^{2}}{\sum_{i=1}^{n}\left(Y_{i}^{\text {obs }}-Y^{\text {mean }}\right)^{2}}\right\rceil
$$

Dimana :

$\mathrm{Yi}^{\text {obs }}=$ Debit pengukuran $(\mathrm{m} 3 / \mathrm{det})$

$\mathrm{Yi}^{\text {sim }}=$ Debit simulasi $(\mathrm{m} 3 / \mathrm{det})$

$\mathrm{Y}^{\text {mean }}=$ Rerata debit pengukuran $(\mathrm{m} 3 / \mathrm{det})$

Nilai NSE berkisar pada angka $-\infty$ sampai 1, dimana NSE $=1$ merupakan batas nilai paling tinggi. Nilai NSE < 0,0 mengindikasikan bahwa rerata debit pengukuran lebih baik untuk dipergunakan sebagai prediksi daripada debit simulasi itu sendiri. Dengan kata lain, bahwa performance model masih belum dapat diterima. Sementara itu, nilai NSE antara 0,0 sampai 1,0 menunjukkan bahwa model mempunyai performance yang dapat diterima. Pengkelasan dalam performance model dengan menggunakan nilai NSE disajikan pada tabel berikut.

Tabel 5.3. Kelas performance nilai NSE

\begin{tabular}{ll}
\hline Performance Rating & NSE \\
\hline Very Good & $0.75<$ NSE $\leq 1.00$ \\
\hline Good & $0.65<$ NSE $\leq 0.75$ \\
\hline Satisfactory & $0.50<$ NSE $\leq 0.65$ \\
\hline Unsatisfactory & NSE $\leq 0.5$ \\
\hline
\end{tabular}




\subsection{Hasil}

\subsubsection{Validasi Model GenRiver}

\section{Lokasi Studi}

Validasi model GenRiver dilakukan pada tiga DAS yaitu DAS Sumber Brantas, Bango dan Amprong. Secara keseluruhan wilayah studi mempunyai luas $774 \mathrm{~km}^{2}$ yang sebagian besar terletak di Kabupaten Malang dan selebihnya di Kota Batu.

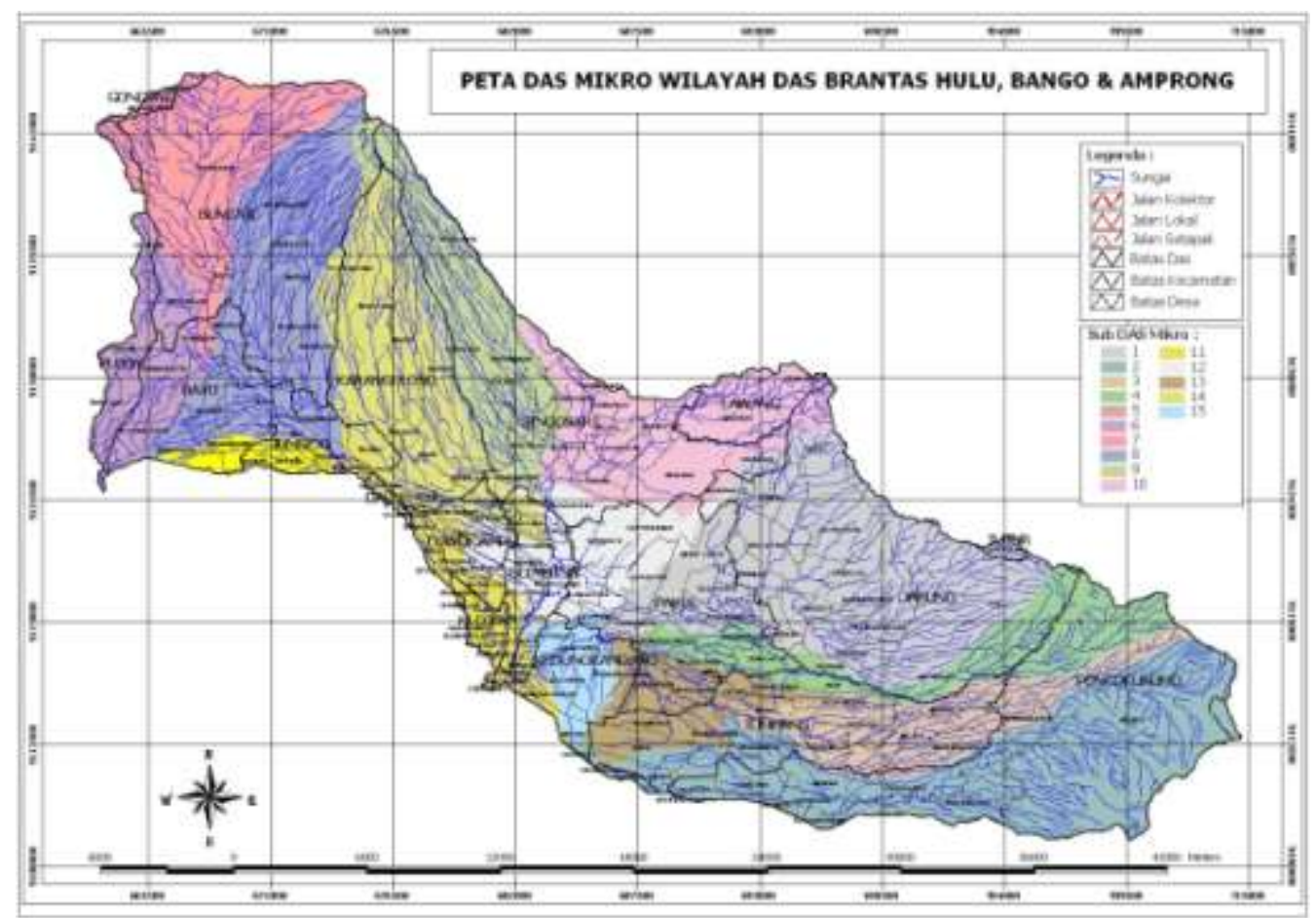

Gambar 5.3. Pembagian subcatchment pada tiga DAS untuk validasi model GenRiver

\section{Data Debit dan Hujan untuk Validasi Model}

Kondisi data hujan dan debit dalam kurun waktu 10 tahun dari tahun 1998 sampai dengan 2007 ditunjukkan pada gambar-gambar berikut. Data debit minimal pada musim kemarau dari tahun-ke tahun terlihat menunjukkan peningkatan nilai. Selain tiu, volume total debit yang dihasilkan oleh sistem hidrologi di ketiga DAS ini pada 5 tahun terakhir menunjukkan jumlah yang tak sebanding dengan volume hujan yang jatuh di seluruh DAS. 


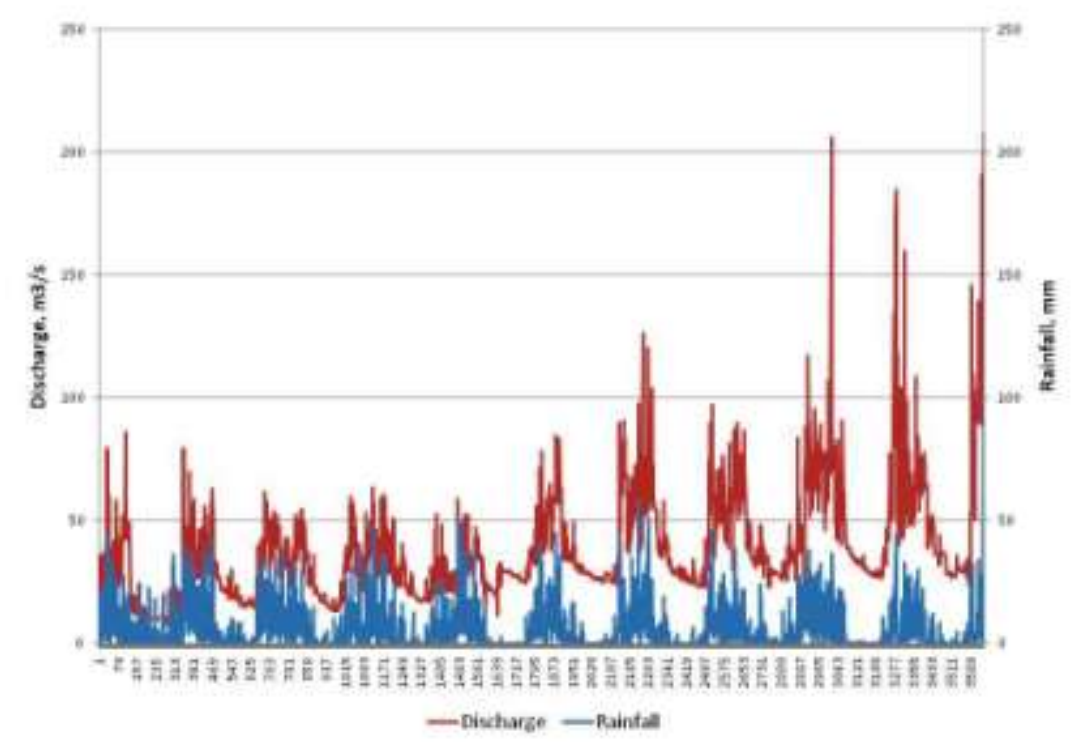

Gambar 5.4. Grafik hujan dan debit harian selama tahun 1998 sampai 2007

Sementara itu, total volume curah hujan dan debit ditunjukkan pada gambar berikut.

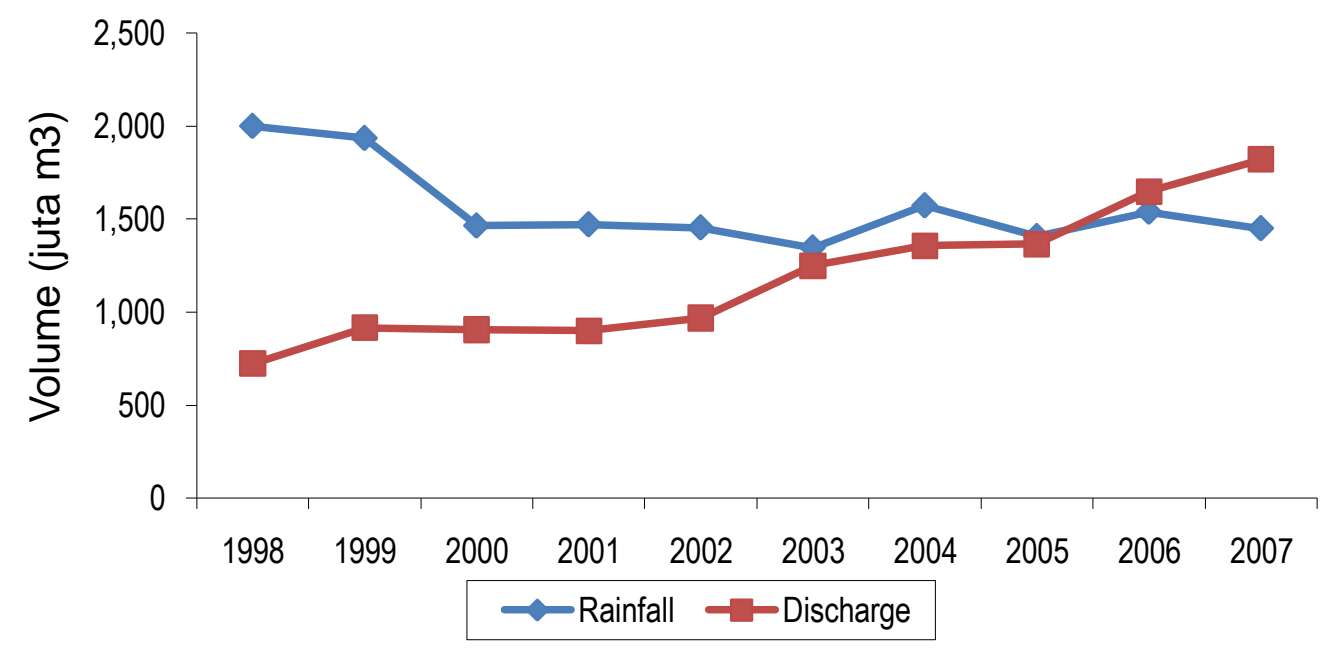

Gambar 5.5. Total volume curah hujan dan debit tahunan

\section{Hasil Validasi Model}

Hasil validasi model GenRiver di ketiga DAS dengan data debit dan hujan selama 10 tahun menunjukkan nilai efisiensi model yang sangat rendah, dengan nilai NSE kurang dari 0 dan nilai $\mathrm{R}^{2}$ antara debit aktual dan debit simulasi (prediksi) sebesar 0,074. Kondisi ini dapat dijelaskan dari data debit yang terlihat tidak logis setelah dihubungkan dengan data hujan, khususnya mulai tahun 2003 sampai dengan 2007. Verifikasi data debit dan hujan sebagai input data utama dalam validasi model ini perlu dilakukan lebih lanjut. 


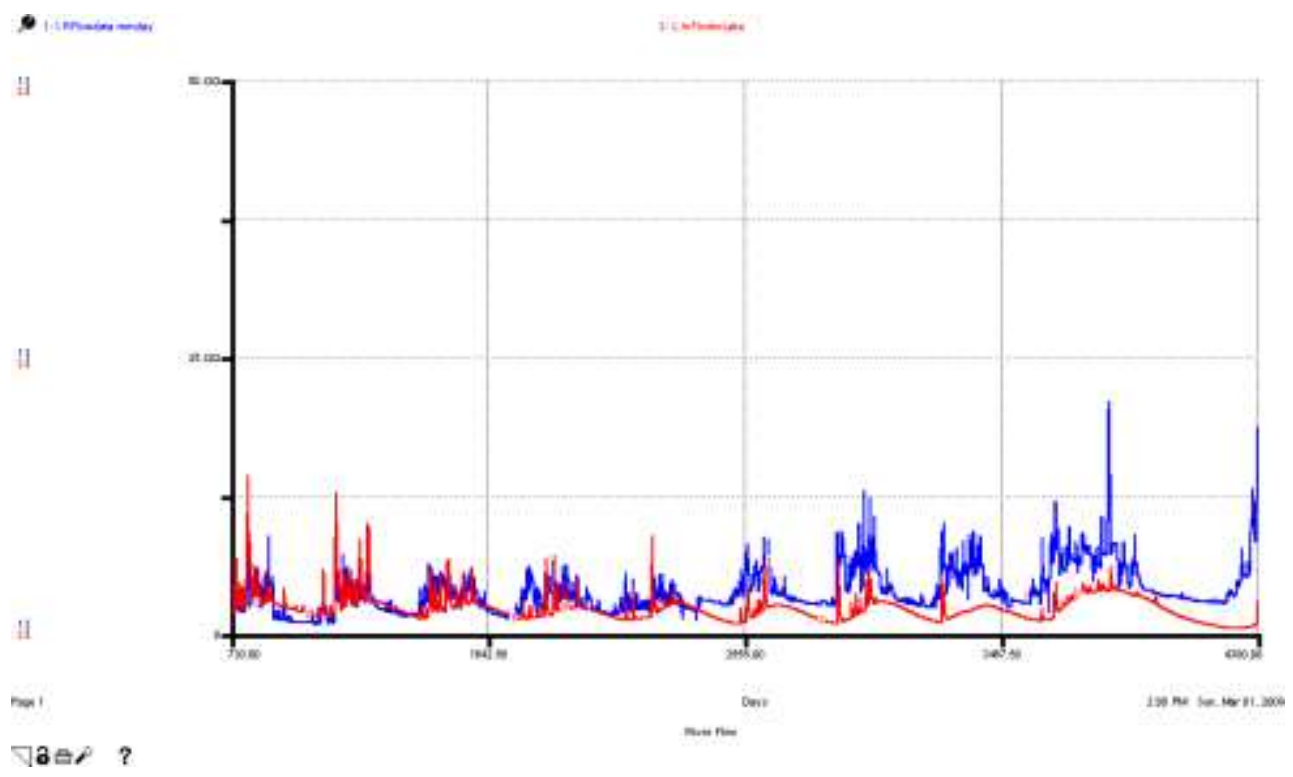

Gambar 5.6. Grafik debit aktual dan debit prediksi hasil simulasi model

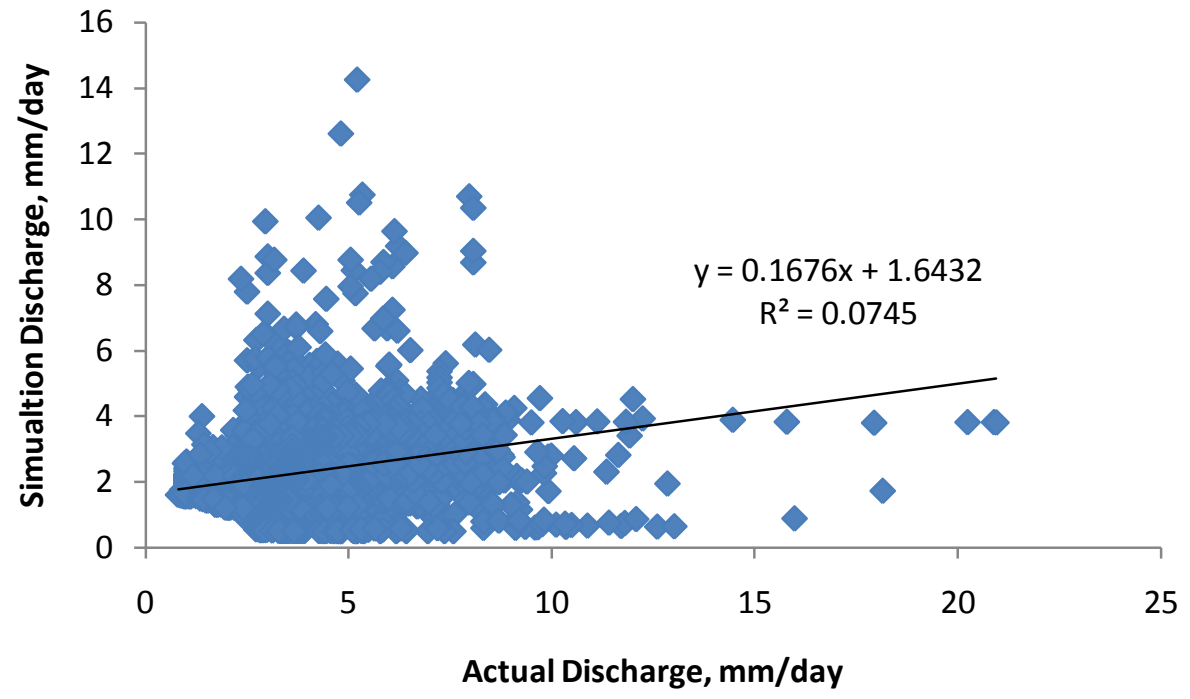

Gambar 5.7. Hubungan antara debit aktual dan debit prediksi hasil simulasi model seluruh tahun

Namun demikian, dari data hujan tahun pertama (1998), diperoleh hubungan antara debit prediksi dan debit aktual dengan nilai $\mathrm{R}^{2}$ sebesar 0,705 . Hal ini menunjukkan bahwa sebesar $70 \%$ debit simulasi (prediksi) yang diperoleh sesuai dengan debit aktual yang ada. 


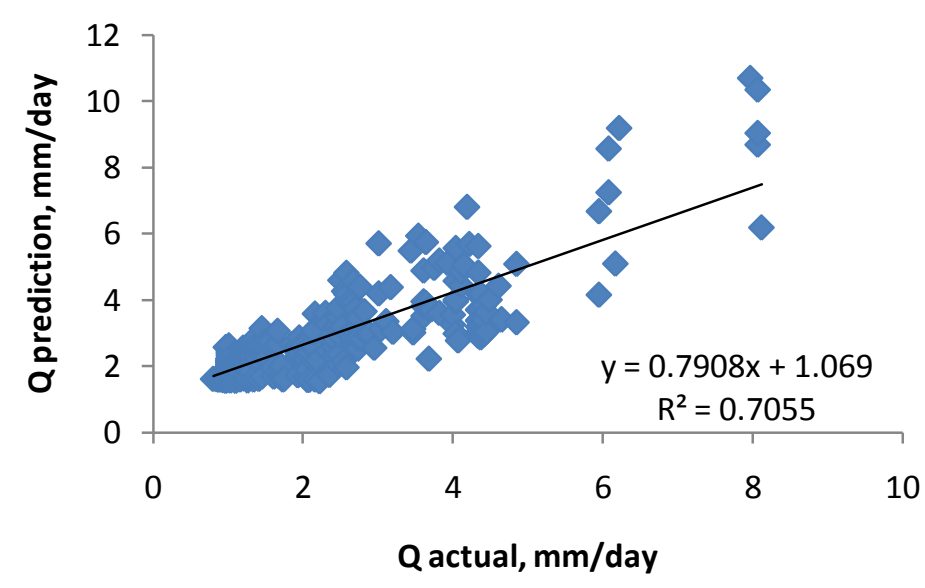

Gambar 5.8. Hubungan antara debit aktual dan debit prediksi hasil simulasi model pada tahun pertama

\subsubsection{Aplikasi Model GenRiver di DAS Sumber Brantas}

\section{Data Hujan dan Debit DAS Sumber Brantas}

Data hujan yang digunakan dalam hal ini adalah data hujan dari tahun 1998 sampai dengan tahun 2007. Lima dari sepuluh data hujan tahunan tersebut menunjukkan nilai hujan tahunan kurang dari $2000 \mathrm{~mm}$, dan selebihnya data hujan tahunan berkisar antara $2000 \mathrm{~mm}-2400$ $\mathrm{mm}$.

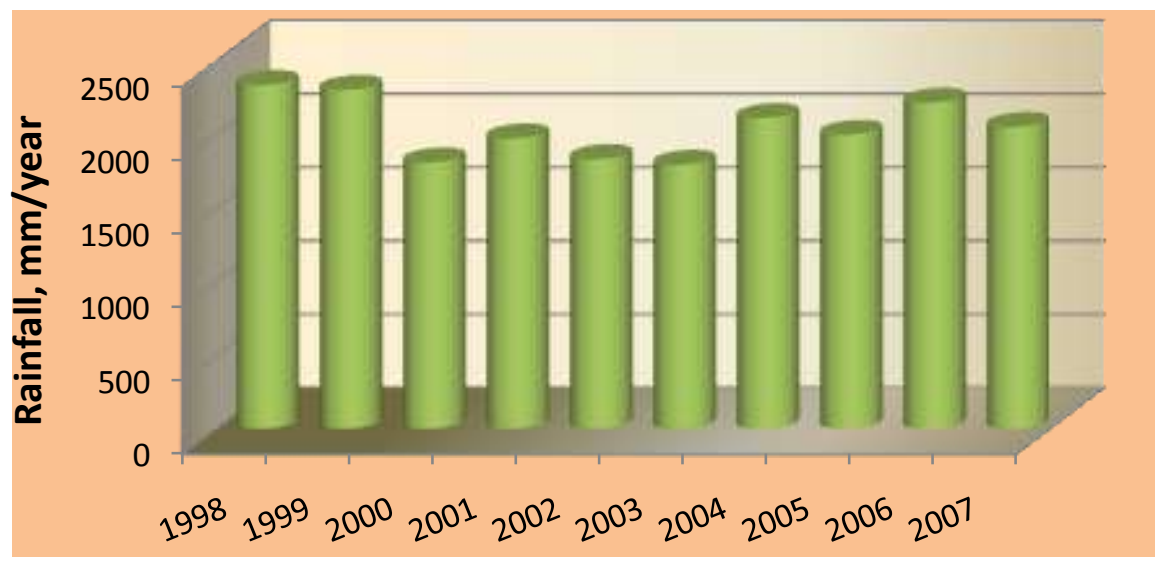

Gambar 5.9. Total hujan tahunan di wilayah DAS Sumber Brantas 
Sebaran data rata-rata hujan harian pada masing-masing tahun ditunjukkan pada gambar berikut.

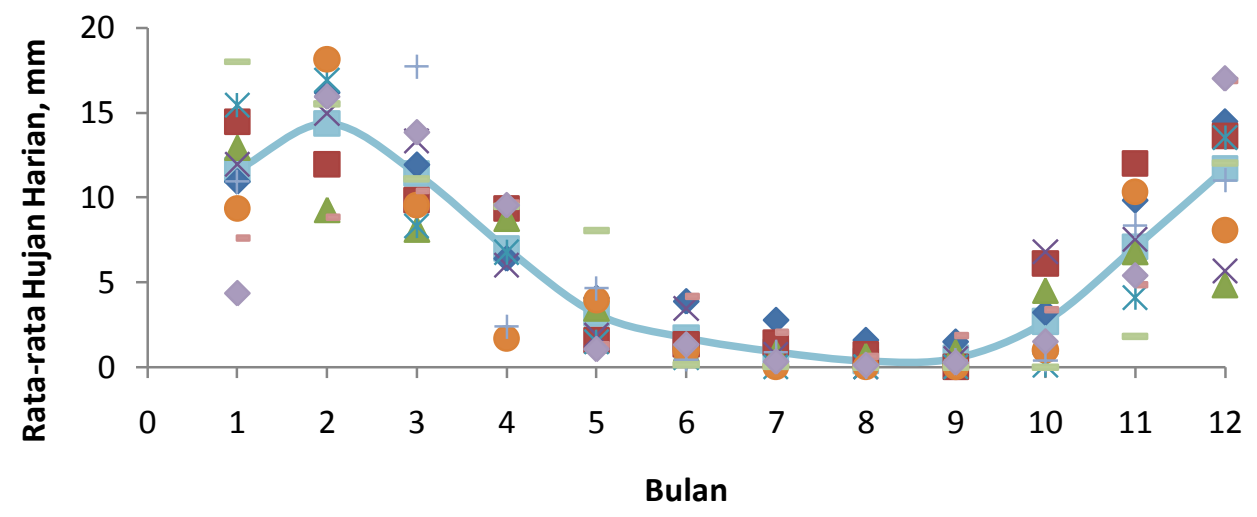

$\begin{array}{lllll}- \text {-Average } & \diamond 1998 & 1999 & \triangle 2000 \\ \times 2001 & * 2002 & \bullet 2003 & +2004 \\ -2005 & -2006 & & \end{array}$

Gambar 5.10. Rata-rata hujan harian tiap bulan dan sebarannya pada masing-masing tahun

Sementara itu, keragaman curah hujan harian musim hujan dan kemarau tiap bulan dari tahun 1998 sampai dengan tahun 2007 serta grafik hujan harian ditunjukkan pada gambar berikut.

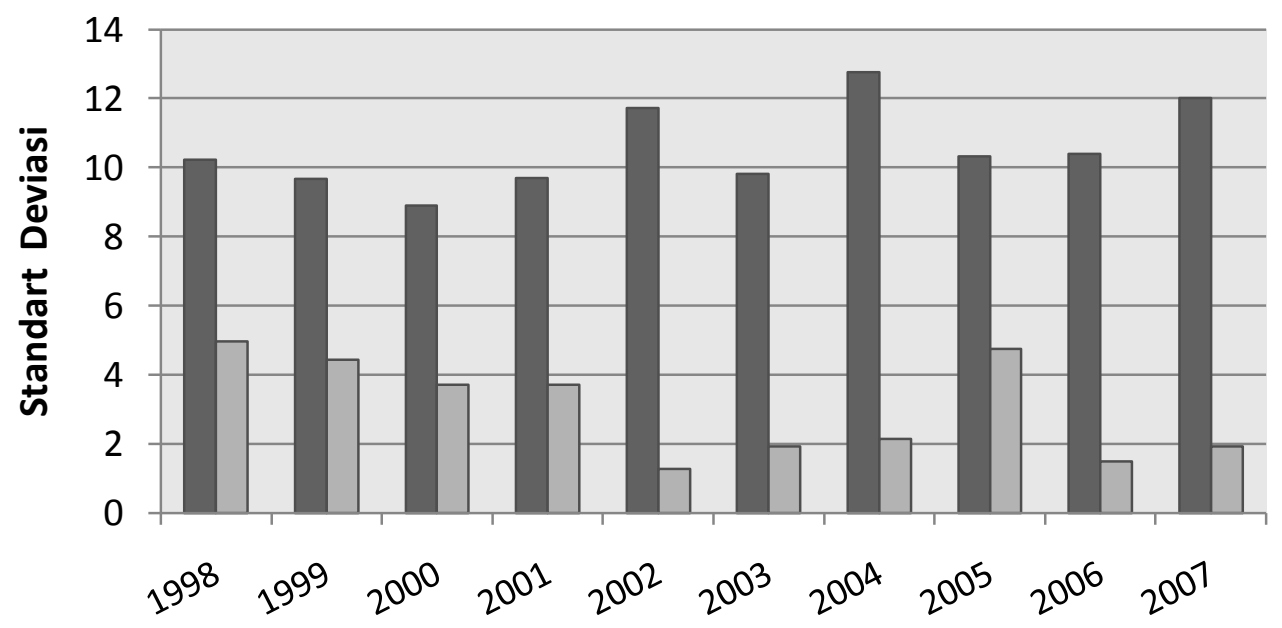

$\square$ Hujan $\square$ Kemarau

Gambar 5.11. Nilai standart deviasi hujan harian pada musim hujan dan kemarau 


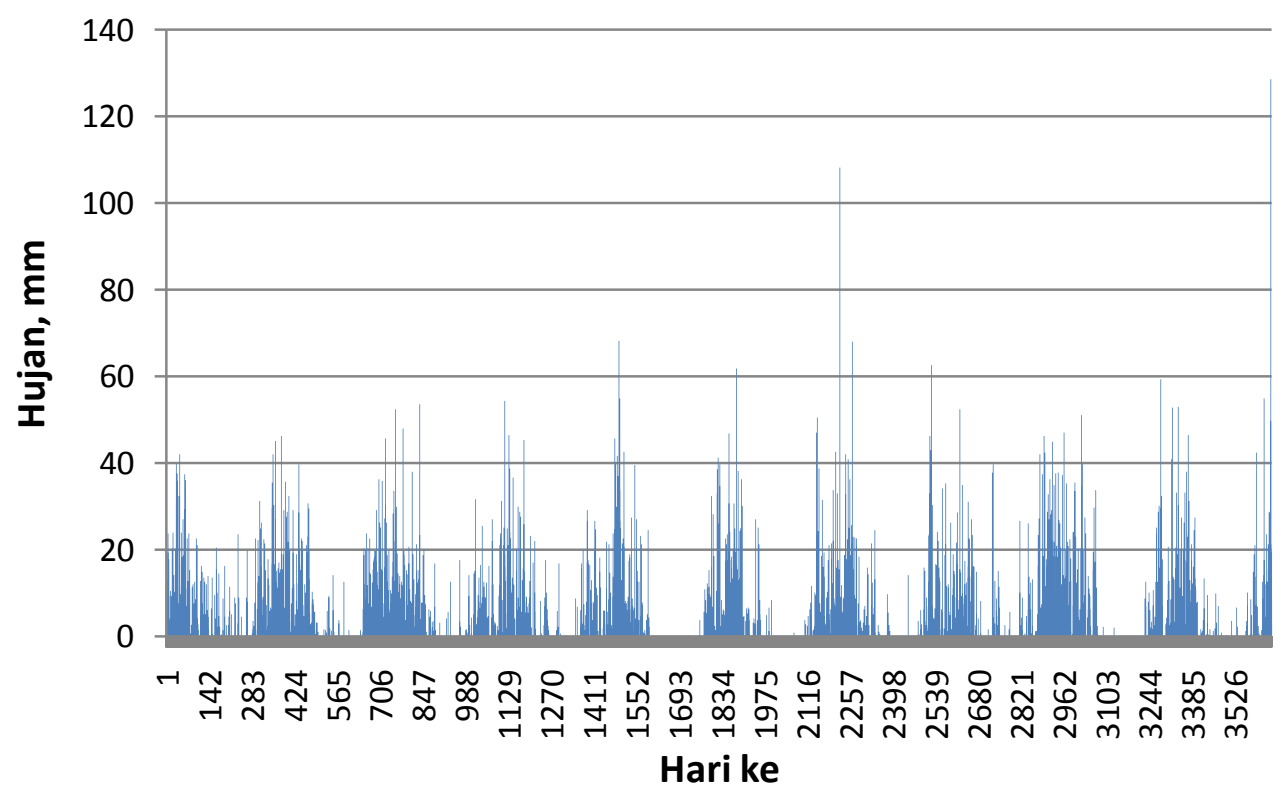

Gambar 5.12. Hujan harian dari keseluruhan tahun

\section{Parameterisasi Model GenRiver}

\section{A. Identifikasi Subcatchment}

Tabel di bawah ini menunjukkan data jumlah subcatchment, luasan dan jarak masing-masing subcatchment terhadap outlet. Titik pengamatan (measurement point) terhadap kondisi debit sungai tidak dilakukan dalam hal ini.

Tabel 5.4. Parameterisasi subcatchment, luas, dan jaraknya terhadap outlet

\begin{tabular}{|c|c|c|c|c|c|c|c|c|c|}
\hline $\begin{array}{l}\text { Sub- } \\
\text { catchment }\end{array}$ & $\begin{array}{l}\text { Fraksi } \\
\text { Luas }\end{array}$ & $\begin{array}{l}\text { Luas } \\
\left(\mathbf{k m}^{2}\right)\end{array}$ & $\begin{array}{l}\text { Routing } \\
\text { Distance } \\
(\mathrm{km})\end{array}$ & Obs1 & Obs2 & Obs3 & Obs4 & Obs5 & Obs6 \\
\hline A & 0.05 & 8.8 & 21.3 & -1 & -1 & -1 & -1 & -1 & -1 \\
\hline$B$ & 0.11 & 18.5 & 24.1 & -1 & -1 & -1 & -1 & -1 & -1 \\
\hline $\mathrm{D}$ & 0.01 & 1.3 & 2.1 & -1 & -1 & -1 & -1 & -1 & -1 \\
\hline$E$ & 0.06 & 10.8 & 16.2 & -1 & -1 & -1 & -1 & -1 & -1 \\
\hline $\mathrm{F}$ & 0.04 & 7.4 & 15.1 & -1 & -1 & -1 & -1 & -1 & -1 \\
\hline I & 0.05 & 7.9 & 17.8 & -1 & -1 & -1 & -1 & -1 & -1 \\
\hline $\mathrm{J}$ & 0.06 & 9.6 & 4.5 & -1 & -1 & -1 & -1 & -1 & -1 \\
\hline $\mathrm{K}$ & 0.06 & 10.9 & 6.4 & -1 & -1 & -1 & -1 & -1 & -1 \\
\hline$L$ & 0.03 & 4.4 & 5.0 & -1 & -1 & -1 & -1 & -1 & -1 \\
\hline $\mathrm{M}$ & 0.11 & 19.0 & 10.5 & -1 & -1 & -1 & -1 & -1 & -1 \\
\hline $\mathrm{N}$ & 0.07 & 11.5 & 11.1 & -1 & -1 & -1 & -1 & -1 & -1 \\
\hline 0 & 0.08 & 13.2 & 15.2 & -1 & -1 & -1 & -1 & -1 & -1 \\
\hline
\end{tabular}


Kondisi jenis tanah pada tiap subcatchment dideskripsikan pada tabel berikut. Data luasan jenis tanah pada masing-masing subcatchment didapatkan dengan mengoverlaykan antara peta jenis tanah dan peta pembagian subcatchment.

Tabel 5.5. Distribusi jenis tanah pada tiap subcatchment

\begin{tabular}{|c|c|c|c|c|c|c|c|c|c|c|}
\hline $\begin{array}{l}\text { Sub- } \\
\text { catchment }\end{array}$ & Alfisols & Andisols & Aridisols & Entisols & Inceptisols & Mollisols & Oxisols & Spodosols & Ultisols & Vertisols \\
\hline A & 0.00 & 0.90 & 0.00 & 0.00 & 0.10 & 0.00 & 0.00 & 0.00 & 0.00 & 0.00 \\
\hline B & 0.00 & 0.71 & 0.00 & 0.01 & 0.22 & 0.06 & 0.00 & 0.00 & 0.00 & 0.00 \\
\hline C & 0.00 & 0.56 & 0.00 & 0.01 & 0.34 & 0.09 & 0.00 & 0.00 & 0.00 & 0.00 \\
\hline D & 0.00 & 0.00 & 0.00 & 0.00 & 0.99 & 0.01 & 0.00 & 0.00 & 0.00 & 0.00 \\
\hline$E$ & 0.05 & 0.03 & 0.00 & 0.00 & 0.83 & 0.09 & 0.00 & 0.00 & 0.00 & 0.00 \\
\hline $\mathrm{F}$ & 0.03 & 0.12 & 0.00 & 0.00 & 0.75 & 0.11 & 0.00 & 0.00 & 0.00 & 0.00 \\
\hline G & 0.03 & 0.27 & 0.00 & 0.03 & 0.59 & 0.07 & 0.00 & 0.00 & 0.00 & 0.00 \\
\hline $\mathrm{H}$ & 0.00 & 0.18 & 0.00 & 0.01 & 0.73 & 0.07 & 0.00 & 0.00 & 0.00 & 0.00 \\
\hline 1 & 0.00 & 0.73 & 0.00 & 0.00 & 0.20 & 0.07 & 0.00 & 0.00 & 0.00 & 0.00 \\
\hline$J$ & 0.08 & 0.21 & 0.00 & 0.01 & 0.68 & 0.02 & 0.00 & 0.00 & 0.00 & 0.00 \\
\hline $\mathrm{K}$ & 0.01 & 0.14 & 0.00 & 0.04 & 0.77 & 0.04 & 0.00 & 0.00 & 0.00 & 0.00 \\
\hline L & 0.00 & 0.00 & 0.00 & 0.00 & 0.96 & 0.04 & 0.00 & 0.00 & 0.00 & 0.00 \\
\hline M & 0.00 & 0.35 & 0.00 & 0.00 & 0.55 & 0.10 & 0.00 & 0.00 & 0.00 & 0.00 \\
\hline $\mathrm{N}$ & 0.00 & 0.33 & 0.00 & 0.00 & 0.44 & 0.22 & 0.00 & 0.00 & 0.00 & 0.00 \\
\hline $\mathrm{O}$ & 0.00 & 0.51 & 0.00 & 0.00 & 0.42 & 0.07 & 0.00 & 0.00 & 0.00 & 0.00 \\
\hline $\begin{array}{l}\text { Time } \\
\text { independent } \\
\text { soil depth, } \\
\mathrm{cm}\end{array}$ & 450.00 & 400 & 110.00 & 475.00 & 470 & 165.00 & 320.00 & 142.50 & 180 & 198.00 \\
\hline $\begin{array}{l}\text { Topsoil } \\
\text { depth, cm }\end{array}$ & 25.00 & 25.00 & 25.00 & 25.00 & 25.00 & 25.00 & 25.00 & 25.00 & 25.00 & 25.00 \\
\hline
\end{tabular}


Tabel 5.6. Nilai asumsi untuk parameter-parameter yang lainnya

\begin{tabular}{lllllll}
\hline $\begin{array}{l}\text { Sub- } \\
\text { catchment }\end{array}$ & $\begin{array}{l}\text { Topsoil } \\
\text { BD/Bdref }\end{array}$ & $\begin{array}{l}\text { Soilquick } \\
\text { flow } \\
\text { capacity, } \\
\text { mm }\end{array}$ & $\begin{array}{l}\text { Plant } \\
\text { available } \\
\text { water, } \\
\mathbf{m m}\end{array}$ & $\begin{array}{l}\text { Inacces- } \\
\text { sible } \\
\text { water, } \\
\mathbf{m m}\end{array}$ & $\begin{array}{l}\text { Max } \\
\text { dynamic } \\
\text { GW } \\
\text { store, } \\
\mathbf{m m}\end{array}$ & $\begin{array}{l}\text { Ground } \\
\text { water } \\
\text { release } \\
\text { fraction }\end{array}$ \\
\hline A & 0.87 & 248.36 & 637.81 & 590.16 & 300 & 0.1 \\
\hline B & 0.96 & 234.49 & 630.25 & 576.88 & 300 & 0.1 \\
\hline C & 1.03 & 223.98 & 631.98 & 575.58 & 300 & 0.1 \\
\hline D & 1.10 & 232.97 & 810.43 & 733.13 & 300 & 0.1 \\
\hline E & 1.05 & 213.01 & 740.24 & 674.65 & 300 & 0.1 \\
\hline F & 1.08 & 209.92 & 705.75 & 642.98 & 300 & 0.1 \\
\hline G & 1.03 & 226.63 & 708.02 & 638.40 & 300 & 0.1 \\
\hline H & 1.04 & 224.03 & 726.40 & 655.70 & 300 & 0.1 \\
\hline I & 0.86 & 228.71 & 612.47 & 564.72 & 300 & 0.1 \\
\hline J & 1.09 & 232.69 & 762.74 & 697.48 & 300 & 0.1 \\
\hline K & 1.10 & 235.02 & 760.92 & 678.67 & 300 & 0.1 \\
\hline L & 1.06 & 226.60 & 788.29 & 713.09 & 300 & 0.1 \\
\hline M & 0.95 & 217.33 & 667.15 & 607.32 & 300 & 0.1 \\
\hline N & 0.96 & 188.03 & 570.53 & 520.98 & 300 & 0.1 \\
\hline O & 1.05 & 227.55 & 662.25 & 606.26 & 300 & 0.1 \\
\hline
\end{tabular}

\section{B. Penentuan tipe penutupan lahan}

Pada dasarnya, pengelompokan jenis penutupan lahan yang dipergunakan untuk input dalam model GenRiver terdiri dari 3 kelompok penutupan lahan. Kelompok pertama adalah landuse alami yang terdiri dari pioner, hutan sekunder muda (young secondary forest), hutan sekunder tua (old secondary forest) dan hutan primer (primary forest). Kelompok kedua adalah landuse agroforestry yang terdiri dari agroforestry early and late production, post productive agroforestry, dan agroforestry pioneer. Kelompok ketiga adalah bentukan-bentukan penggunaan lahan lainnya seperti sawah teririgasi, tanaman semusim, pemukiman dan sebagainya. Fraksi tiap-tiap landcover pada setiap subcatchment di DAS Sumber Brantas selengkapnya disajikan pada tabel 5.7.

Sementara itu, perkiraan (guestimation) dari pengaruh tiap landcover terhadap kondisi water ballance di lokasi studi disajikan pada tabel 5.8. 
Tabel 5.7. Distribusi jenis landcover pada tiap subcatchment dan hasil estimasi BD/BDref

\begin{tabular}{|c|c|c|c|c|c|c|c|c|c|c|c|c|c|}
\hline Land Cover Type & Pioneer & YoungSec & OldSec & PrimFor & $\begin{array}{l}\text { Water } \\
\text { body }\end{array}$ & $\mathrm{AF}_{\text {Prod }}$ Early & $\begin{array}{c}\mathrm{AF}_{\text {Prod }} \text { Late } \\
\text { Pand }\end{array}$ & Pine & Crop & $\begin{array}{l}\text { Paddy } \\
\text { Rice }\end{array}$ & Houses & Total & $\begin{array}{c}\text { Mean } \\
\text { BD/BDref }\end{array}$ \\
\hline $\mathrm{A}$ & 0.12 & 0.00 & 0.23 & 0.25 & 0.00 & 0.07 & 0.00 & 0.31 & 0.02 & 0.00 & 0.00 & 1.00 & 0.87 \\
\hline $\mathrm{B}$ & 0.18 & 0.00 & 0.11 & 0.13 & 0.00 & 0.06 & 0.00 & 0.25 & 0.24 & 0.00 & 0.03 & 1.00 & 0.96 \\
\hline $\mathrm{C}$ & 0.47 & 0.00 & 0.04 & 0.06 & 0.00 & 0.10 & 0.00 & 0.08 & 0.24 & 0.00 & 0.01 & 1.00 & 1.03 \\
\hline $\mathrm{D}$ & 0.30 & 0.00 & 0.00 & 0.01 & 0.00 & 0.34 & 0.00 & 0.01 & 0.06 & 0.09 & 0.19 & 1.00 & 1.10 \\
\hline $\mathrm{E}$ & 0.36 & 0.00 & 0.02 & 0.01 & 0.00 & 0.24 & 0.00 & 0.07 & 0.26 & 0.00 & 0.05 & 1.00 & 1.05 \\
\hline $\mathrm{F}$ & 0.29 & 0.00 & 0.01 & 0.02 & 0.00 & 0.25 & 0.00 & 0.03 & 0.25 & 0.01 & 0.13 & 1.00 & 1.08 \\
\hline $\mathrm{G}$ & 0.29 & 0.00 & 0.04 & 0.05 & 0.00 & 0.28 & 0.00 & 0.09 & 0.18 & 0.01 & 0.06 & 1.00 & 1.03 \\
\hline $\mathrm{H}$ & 0.21 & 0.00 & 0.05 & 0.07 & 0.00 & 0.25 & 0.00 & 0.04 & 0.24 & 0.01 & 0.13 & 1.00 & 1.04 \\
\hline 1 & 0.26 & 0.00 & 0.07 & 0.40 & 0.00 & 0.08 & 0.00 & 0.11 & 0.06 & 0.00 & 0.00 & 1.00 & 0.86 \\
\hline$J$ & 0.24 & 0.00 & 0.00 & 0.00 & 0.00 & 0.18 & 0.00 & 0.02 & 0.40 & 0.03 & 0.13 & 1.00 & 1.09 \\
\hline $\mathrm{K}$ & 0.17 & 0.00 & 0.01 & 0.00 & 0.00 & 0.24 & 0.00 & 0.02 & 0.32 & 0.04 & 0.20 & 1.00 & 1.10 \\
\hline $\mathrm{L}$ & 0.30 & 0.00 & 0.04 & 0.04 & 0.00 & 0.26 & 0.00 & 0.00 & 0.12 & 0.13 & 0.11 & 1.00 & 1.06 \\
\hline$M$ & 0.20 & 0.00 & 0.25 & 0.15 & 0.00 & 0.19 & 0.00 & 0.05 & 0.06 & 0.04 & 0.05 & 1.00 & 0.95 \\
\hline $\mathrm{N}$ & 0.28 & 0.00 & 0.07 & 0.19 & 0.00 & 0.11 & 0.00 & 0.13 & 0.18 & 0.00 & 0.04 & 1.00 & 0.96 \\
\hline 0 & 0.22 & 0.00 & 0.05 & 0.06 & 0.00 & 0.24 & 0.00 & 0.08 & 0.20 & 0.00 & 0.15 & 1.00 & 1.05 \\
\hline BD/BDref & 1.08 & 0 & 0.85 & 0.63 & 0 & 1.02 & 0 & 0.95 & 1.07 & 1.1 & 1.3 & & \\
\hline
\end{tabular}


Tabel 5.8. Jenis landcover dan pengaruhnya terhadap water ballance

\begin{tabular}{|c|c|c|c|c|c|c|c|c|c|c|c|c|c|c|c|c|}
\hline \multirow{2}{*}{ Landcover type } & \multirow{2}{*}{$\mathrm{BD} / \mathrm{BD}$ ref } & \multirow{2}{*}{$\begin{array}{c}\text { Potential } \\
\text { Intercep-tion } \\
\text { (mm day-1) }\end{array}$} & \multirow{2}{*}{$\begin{array}{l}\text { Relative } \\
\text { Drought } \\
\text { Threshold }\end{array}$} & \multicolumn{12}{|c|}{ Multiplier of Daily Potential Evapotranspiration } & \multirow{2}{*}{$\begin{array}{c}\text { Landcover Epo } \\
\text { mm year }{ }^{-1} \\
\end{array}$} \\
\hline & & & & Jan & Feb & Mar & Apr & May & Jun & Jul & Aug & Sep & Oct & Nov & Dec & \\
\hline Pioneer & 1.08 & 1 & 0.55 & 0.5 & 0.5 & 0.5 & 0.5 & 0.5 & 0.5 & 0.5 & 0.5 & 0.5 & 0.5 & 0.5 & 0.5 & 1786.95 \\
\hline YoungSec & 0 & 0 & 0 & 0.6 & 0.6 & 0.6 & 0.6 & 0.6 & 0.6 & 0.6 & 0.6 & 0.6 & 0.6 & 0.6 & 0.6 & 2144.34 \\
\hline OldSec & 0.85 & 3.5 & 0.5 & 0.8 & 0.8 & 0.8 & 0.8 & 0.8 & 0.8 & 0.8 & 0.8 & 0.8 & 0.8 & 0.8 & 0.8 & 2859.13 \\
\hline PrimFor & 0.63 & 3.5 & 0.45 & 0.8 & 0.8 & 0.8 & 0.8 & 0.8 & 0.8 & 0.8 & 0.8 & 0.8 & 0.8 & 0.8 & 0.8 & 2859.13 \\
\hline Water body & 0 & 0 & 0 & 1 & 1 & 1 & 1 & 1 & 1 & 1 & 1 & 1 & 1 & 1 & 1 & 3573.91 \\
\hline AF_EarlyProd & 1.02 & 2 & 0.55 & 0.6 & 0.6 & 0.6 & 0.6 & 0.6 & 0.6 & 0.6 & 0.6 & 0.6 & 0.6 & 0.6 & 0.6 & 2144.34 \\
\hline AF_LateProd & 0 & 0 & 0 & 0.7 & 0.7 & 0.7 & 0.7 & 0.7 & 0.7 & 0.7 & 0.7 & 0.7 & 0.7 & 0.7 & 0.7 & 2501.73 \\
\hline Pine & 0.95 & 3.5 & 0.3 & 1 & 1 & 1 & 1 & 1 & 1 & 1 & 1 & 1 & 1 & 1 & 1 & 3573.91 \\
\hline Crop & 1.07 & 1 & 0.7 & 1 & 1 & 1 & 1 & 1 & 1 & 0.7 & 0.3 & 0.5 & 0.5 & 0.5 & 0.8 & 2795.92 \\
\hline Paddy Rice & 1.1 & 1 & 0.8 & 1 & 1 & 1 & 1 & 1 & 1 & 1 & 1 & 1 & 1 & 1 & 1 & 3573.91 \\
\hline Houses & 1.3 & 0.05 & 0.01 & 0.01 & 0.01 & 0.01 & 0.01 & 0.01 & 0.01 & 0.01 & 0.01 & 0.01 & 0.01 & 0.01 & 0.01 & 35.74 \\
\hline \multicolumn{4}{|c|}{ Potensial evapotranspiration, $\mathrm{mm} /$ month } & 305 & 282 & 305 & 328 & 337 & 271 & 260 & 253 & 279 & 326 & 318 & 309 & \\
\hline
\end{tabular}

Keterangan :

Young sec dan AF_Late Prod tidak ada dalam tata guna lahan di lokasi studi 


\section{Skenario Penggunaan Lahan}

Skenario 1. Landuse tahun 1989

Skenario 1 mengacu pada landuse tahun 1989 dimana landuse ini mewakili kondisi penutupan lahan di lokasi studi sebelum terjadinya illegal logding (masa reformasi). Kondisi landuse pada tahun tersebut disajikan pada gambar berikut.

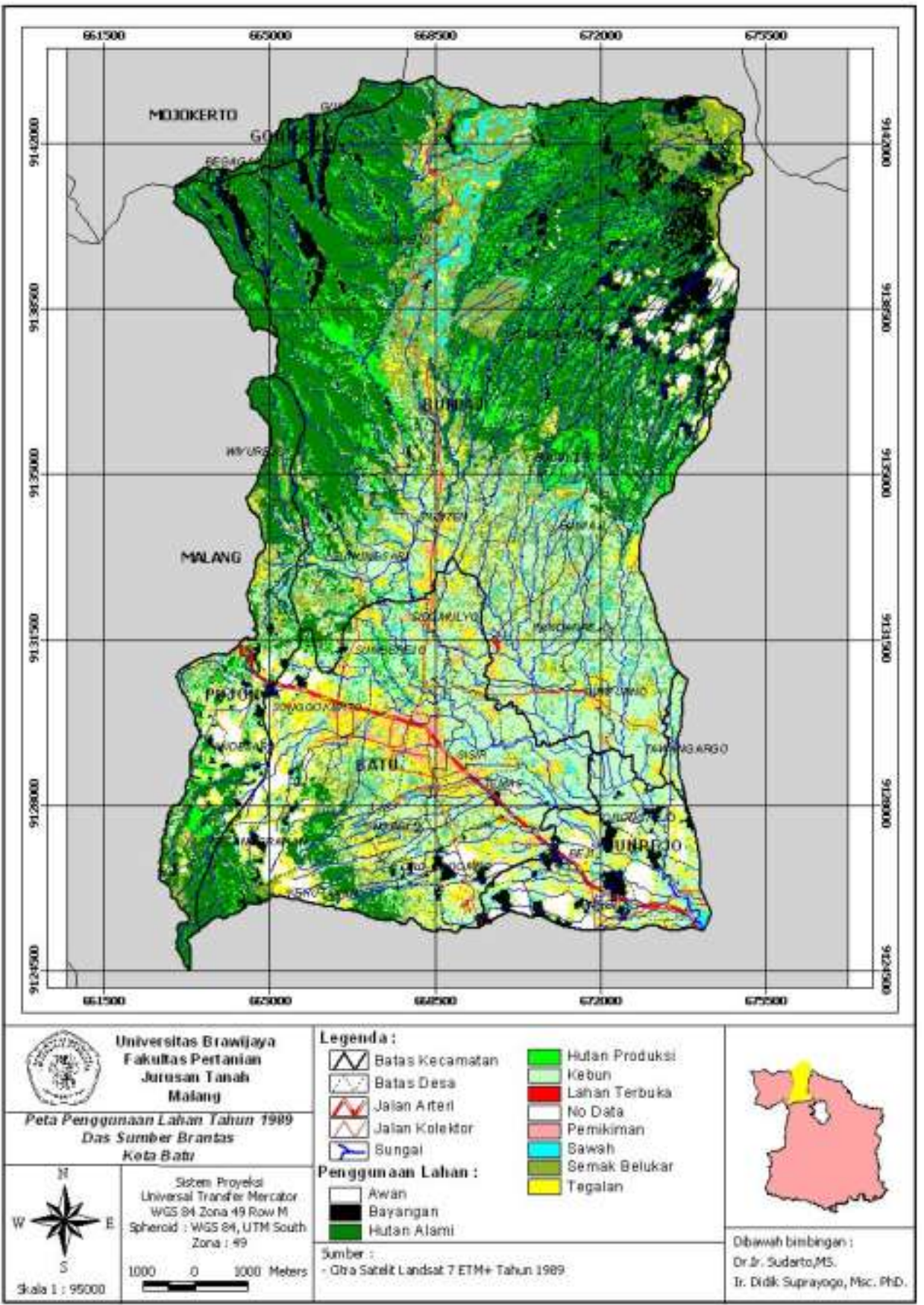

Gambar 5.11. Kondisi landuse di DAS Sumber Brantas tahun 1989 
Terdapat 3 jenis penggunaan lahan yang utama pada tahun ini yaitu hutan alami, kebun (perkebunan apel), serta semak belukar. Jenis penutupan lahan serta luasannya disajikan pada tabel berikut.

Tabel 5.9. Jenis penutupan lahan dan luasannya untuk skenario 1

\begin{tabular}{rlrc}
\hline No & Landuse & Luas (Ha) & Persentase \\
\hline 1 & No Data & 8.1 & 0.05 \\
\hline 2 & Kebun & 4070.07 & 23.41 \\
\hline 3 & Tegalan & 1650.51 & 9.49 \\
\hline 4 & Hutan Alami & 5304.42 & 30.51 \\
\hline 5 & Lahan Terbuka & 31.59 & 0.18 \\
\hline 6 & Pemukiman & 240.39 & 1.38 \\
\hline 7 & Bayangan & 1125.02 & 6.47 \\
\hline 8 & Sawah & 711.54 & 4.09 \\
\hline 9 & Awan & 711.27 & 4.09 \\
\hline 10 & Semak Belukar & 2316.33 & 13.32 \\
\hline 11 & Hutan Produksi & 1215.27 & 6.99 \\
\hline & Total & 17384.51 & 100 \\
\hline
\end{tabular}

Skenario 2. Landuse tahun 2002

Skenario kedua mengacu pada landuse sesaat setelah terjadinya masa reformasi pada tahun 1998/1999. Jenis penggunaan lahan serta luasan landuse pada tahun ini menunjukkan bahwa luasan hutan alami telah berkurang menjadi kurang dari $10 \%$ dari total luas catchment, jika dibandingkan dengan landuse tahun 1989. Berkurangnya luasan lahan hutan alami ini ternyata disebabkan karena hutan alami telah berubah menjadi hutan terganggu, hutan produksi, dan semak belukar. Hutan produksi dalam hal ini adalah hutan-hutan milik Perhutani yang telah ditanami tanaman semusim (tetelan). Sementara itu, hutan terganggu mempunyai kondisi yang lebih bagus daripada hutan produksi dimana tegakan pohon masih mendominasi. Sementara itu, semak belukar kebanyakan adalah lahan yang dulunya hutan dan setelah ditebang pohonnya menjadi lahan terlantar yang kemudian ditumbuhi oleh semak belukar. Lahan-lahan ini pada umumnya berada pada posisi lereng yang curam. Lebih jelasnya, jenis penutupan lahan dan luasannya disajikan pada tabel 5.10 dan gambar 5.14. 
Tabel 5.10. Jenis penutupan lahan dan luasannya untuk skenario 2

\begin{tabular}{llrc}
\hline No & Landuse & Luas (Ha) & Persentase \\
\hline 1 & No Data & 8.73 & 0.05 \\
\hline 2 & Kebun & 2917.71 & 16.78 \\
\hline 3 & Tegalan & 2289.33 & 13.17 \\
\hline 4 & Hutan Alami & 1602.81 & 9.22 \\
\hline 5 & Lahan Terbuka & 25.74 & 0.15 \\
\hline 6 & Pemukiman & 1343.61 & 7.73 \\
\hline 7 & Bayangan & 667.44 & 3.84 \\
\hline 8 & Sawah & 671.58 & 3.86 \\
\hline 9 & Awan & 100.64 & 0.58 \\
\hline 10 & Semak Belukar & 3722.85 & 21.41 \\
\hline 11 & Hutan Terganggu & 2386.44 & 13.73 \\
\hline 12 & Hutan Produksi & 1647.63 & 9.48 \\
\hline & Total & 17384.51 & 100 \\
\hline
\end{tabular}

Skenario 3. Landuse tahun 2006

Kondisi landuse aktual diwakili oleh landuse tahun 2006 dimana jenis dan komposisi landuse disajikan pada gambar 5.15 dan tabel 5.11 .

Tabel 5.11. Jenis dan luasan penutupan lahan tahun 2006

\begin{tabular}{llrc}
\hline No & Landuse & Luas (Ha) & Persentase \\
\hline 1 & No Data & 76.59 & 0.4 \\
\hline 2 & Kebun & 3171.20 & 18.2 \\
\hline 3 & Tegalan & 3484.64 & 20.0 \\
\hline 5 & Hutan Alami & 1374.01 & 7.9 \\
\hline 6 & Lahan Terbuka & 92.50 & 0.05 \\
\hline 7 & Pemukiman & 1253.21 & 7.2 \\
\hline 8 & Bayangan & 348.86 & 2.0 \\
\hline 9 & Sawah & 268.34 & 1.5 \\
\hline 10 & Awan & 539.37 & 3.1 \\
\hline 11 & Semak & 4386.33 & 25.2 \\
\hline 12 & Hutan Terganggu & 804.85 & 4.6 \\
\hline & total & 1584.63 & 100 \\
\hline
\end{tabular}




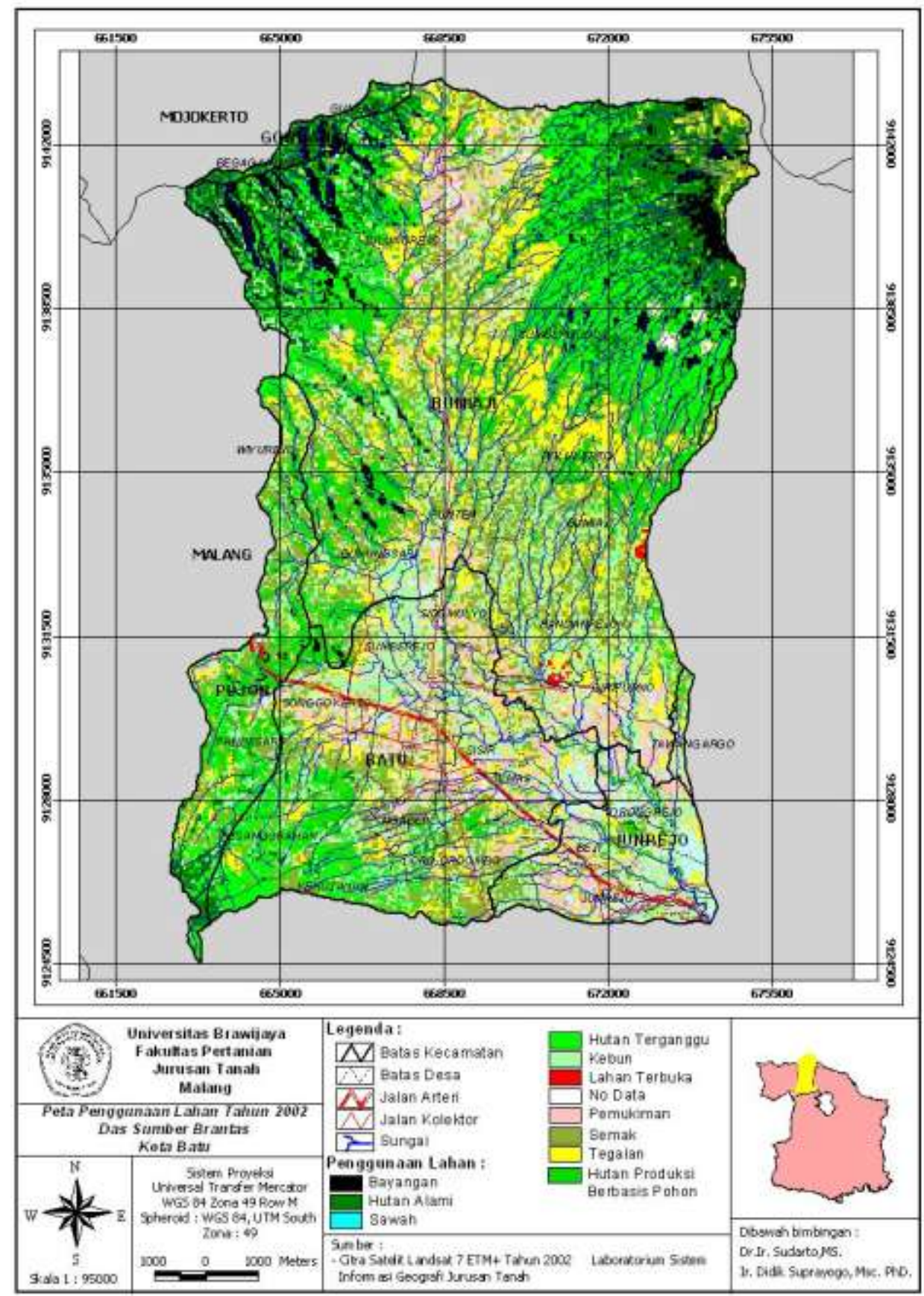

Gambar 5.12. Kondisi landuse di DAS Sumber Brantas tahun 2002 


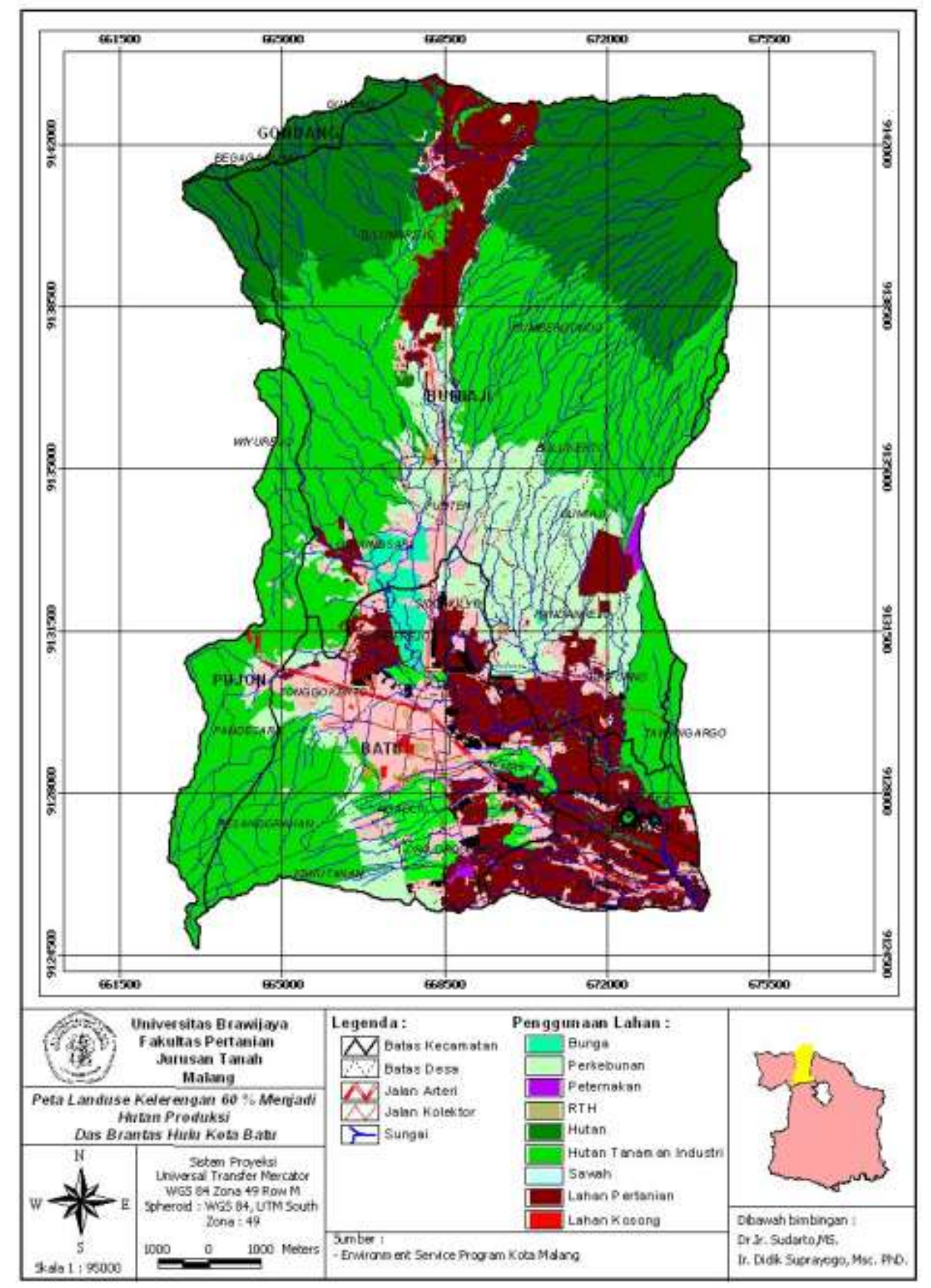

Gambar 5.13. Kondisi landuse tahun 2006

Skenario 3. Landuse RTRW dan hutan recovery

Skenario ketiga ditetapkan berdasarkan Rencana Tata Ruang dan Wilayah (RTRW) Kota Batu yang rencananya telah diimplementasikan pada tahun 2005 yang lalu. Namun demikian, RTRW yang baru masih dalam proses penyusunan sehingga masih belum dapat dipergunakan sebagai acuan untuk skenario. Karena perencanaan wilayah hutan baik itu hutan milik Perhutani maupun Tahura (Taman Hutan Raya) diluar otoritas pemerintah Kota Batu, sehingga dalam skenario ketiga ini ditetapkan seluruh kawasan hutan yang telah berubah fungsi dikembalikan lagi pada fungsi sebenarnya yaitu sebagai hutan alami dan hutan produksi (Hutan Tanaman Industri). 


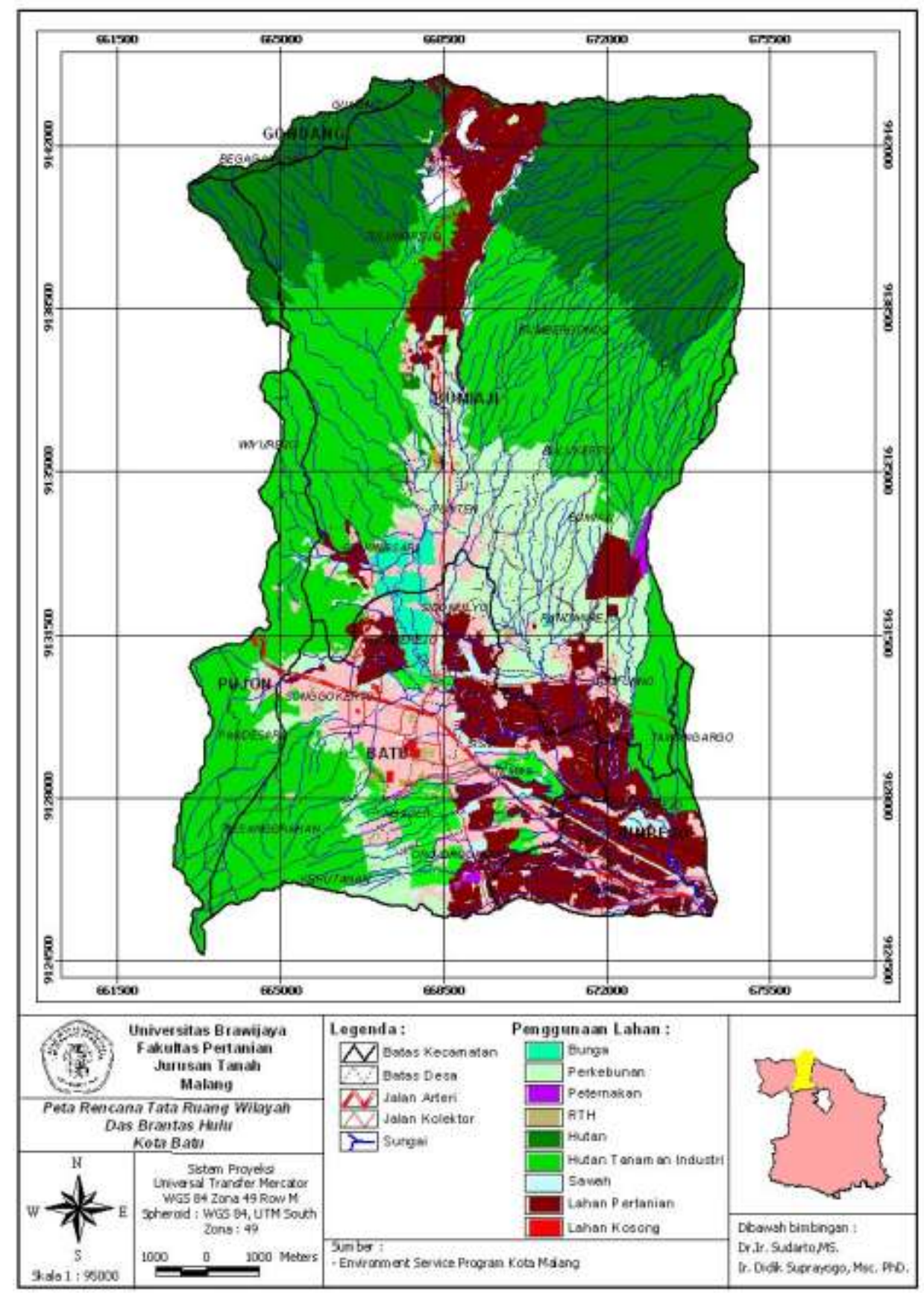

Gambar 5.14. Kondisi landuse RTRW dan hutan recovery 
Tabel 5.12. Jenis penutupan lahan dan luasannya untuk skenario 3

\begin{tabular}{llrc}
\hline No & Landuse & Luas (Ha) & Persentase \\
\hline 1 & Pemukiman & 1747.56 & 10.05 \\
\hline 2 & Kebun & 2478.83 & 14.26 \\
\hline 3 & Agroforestry & 807.15 & 4.64 \\
\hline 4 & Sayuran & 2099.00 & 12.07 \\
\hline 5 & Hutan Produksi & 6238.32 & 35.88 \\
\hline 6 & Hutan Alami & 3638.73 & 20.93 \\
\hline 8 & Lahan Terbuka & 20.02 & 0.12 \\
\hline & Sawah & 354.90 & 2.04 \\
\hline
\end{tabular}

\section{Dampak Skenario Perumbahan Penggunaan Lahan terhadap Kondisi Hidrologi DAS}

\section{Sumber Brantas}

\section{A. Fluktuasi Debit Harian}

Data hujan yang dipergunakan untuk ketiga skenario penggunaan lahan adalah data hujan dari tahun 1998 sampai dengan tahun 2007. Hasil fluktuasi debit harian diambil dari salah satu tahun (1998) disajikan pada gambar berikut.
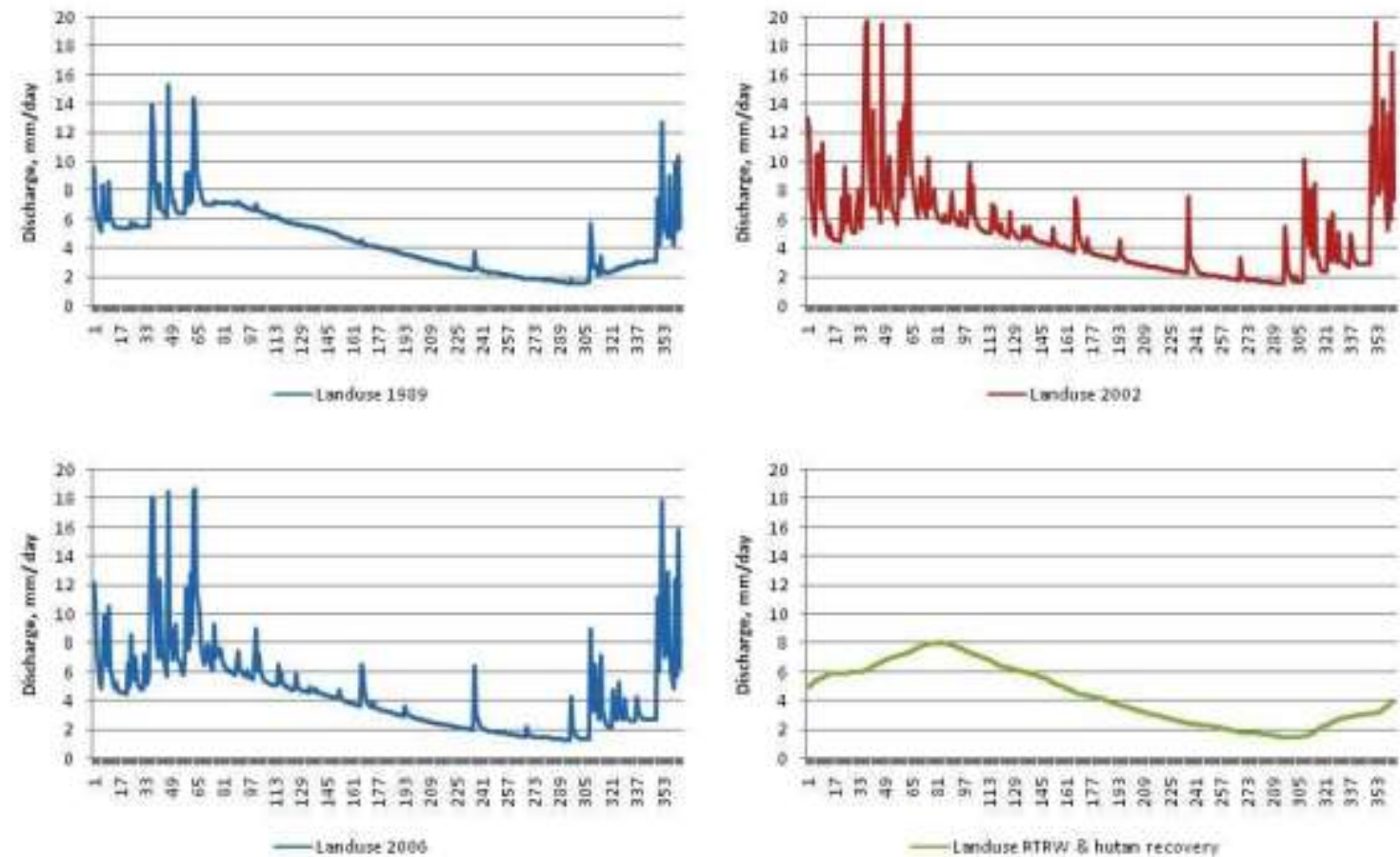

Gambar 5.15. Fluktuasi debit harian berbagai scenario 


\section{B. Fluktuasi Debit Musim Hujan dan Kemarau}

Fluktuasi debit antara musim hujan dan musim kemarau pada setiap skenario penggunaan lahan menunjukkan bahwa kondisi landuse aktual mempunyai perbedaan total debit musim kemarau dan musim penghujan yang paling tinggi. Nilai perbedaan tersebut hampir sama dengan kondisi pada saat landuse setelah reformasi. Sementara itu, skenario landuse ke-3 menunjukkan nilai perbedaan debit musim kemarau dan penghujan yang paling rendah dalam hal ini jumlah debit musim kemarau telah melebihi 50\% dari debit total pada musim penghujan. Rasio serta perbandingan antara debit kemarau dengan penghujan ditunjukkan pada tabel dan grafik berikut.

Tabel 5.13. Rasio debit musim kemarau dan penghujan (data hujan tahun 2004)

\begin{tabular}{lc}
\hline Landuse & Rasio Kemarau/Penghujan \\
\hline Landuse 1989 & 0.51 \\
\hline Landuse 2002 & 0.39 \\
\hline Landuse 2006 & 0.38 \\
\hline Landuse RTRW \& hutan recovery & 0.66 \\
\hline
\end{tabular}

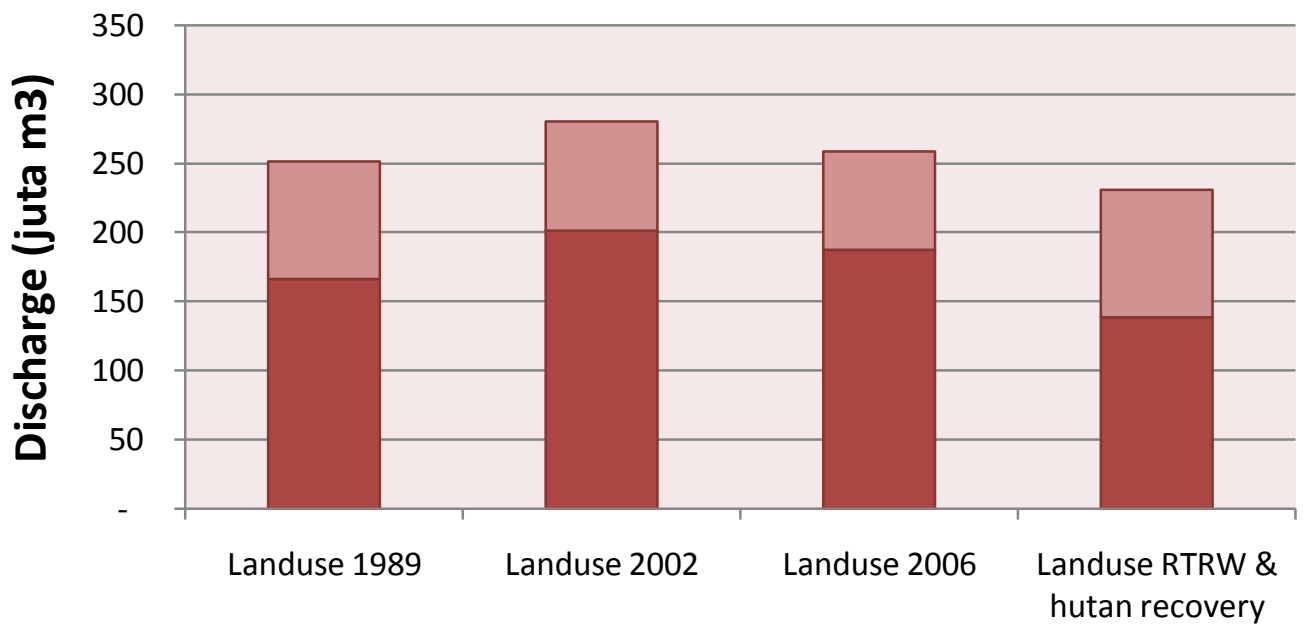

Debit Penghujan $\square$ Debit Kemarau

Gambar 5.16. Perbandingan debit musim kemarau dan penghujan (data hujan tahun 2004) 
C. Kondisi Water Ballance pada tiap skenario penggunaan lahan

Kondisi water ballance yang meliputi total hujan, intersepsi, evapotranspirasi dan river outflow disajikan pada tabel berikut.

Tabel 5.14. Kondisi water ballance pada tiap skenario penggunaan lahan

\begin{tabular}{lccccccc}
\hline & \multicolumn{3}{l}{ Flow Pathways $(\mathbf{m m})$} & & \multicolumn{2}{c}{ Water ballance terms in mm over 10 years $(\mathbf{m m})$} \\
\cline { 2 - 8 } $\begin{array}{l}\text { Skenario } \\
\text { Landuse }\end{array}$ & $\begin{array}{l}\text { Surf Quick } \\
\text { flow }\end{array}$ & $\begin{array}{l}\text { Soil } \\
\text { Quick } \\
\text { flow }\end{array}$ & Base flow & Cum Rain & $\begin{array}{l}\text { Cum } \\
\text { Intercep }\end{array}$ & $\begin{array}{l}\text { Cum Evap } \\
\text { Transp }\end{array}$ & $\begin{array}{l}\text { CumRiv } \\
\text { Outflow }\end{array}$ \\
\hline $\begin{array}{l}\text { Aktual } \\
\text { Landuse }\end{array}$ & $4,134.36$ & 192.89 & $10,314.69$ & $20,542.65$ & $2,780.45$ & $5,965.35$ & $14,635.74$ \\
\hline Skenario 1 & $1,804.04$ & - & $12,569.79$ & $20,542.65$ & $3,543.44$ & $6,264.81$ & $14,369.57$ \\
\hline Skenario 2 & $5,035.72$ & - & $10,725.17$ & $20,542.65$ & $2,717.61$ & $4,849.96$ & $15,753.39$ \\
\hline Skenario 3 & 93.60 & 4.67 & $13,521.49$ & $20,542.65$ & $2,888.85$ & $7,028.17$ & $13,622.33$ \\
\hline
\end{tabular}

Sementara itu, rata-rata harian kondisi water ballance untuk keseluruhan skenario penggunaan lahan dan landuse aktual disajikan pada gambar 5.19. Sedangkan hubungan antara kondisi waterballance dengan total hujan tahunan disajikan pada gambar 5.20.

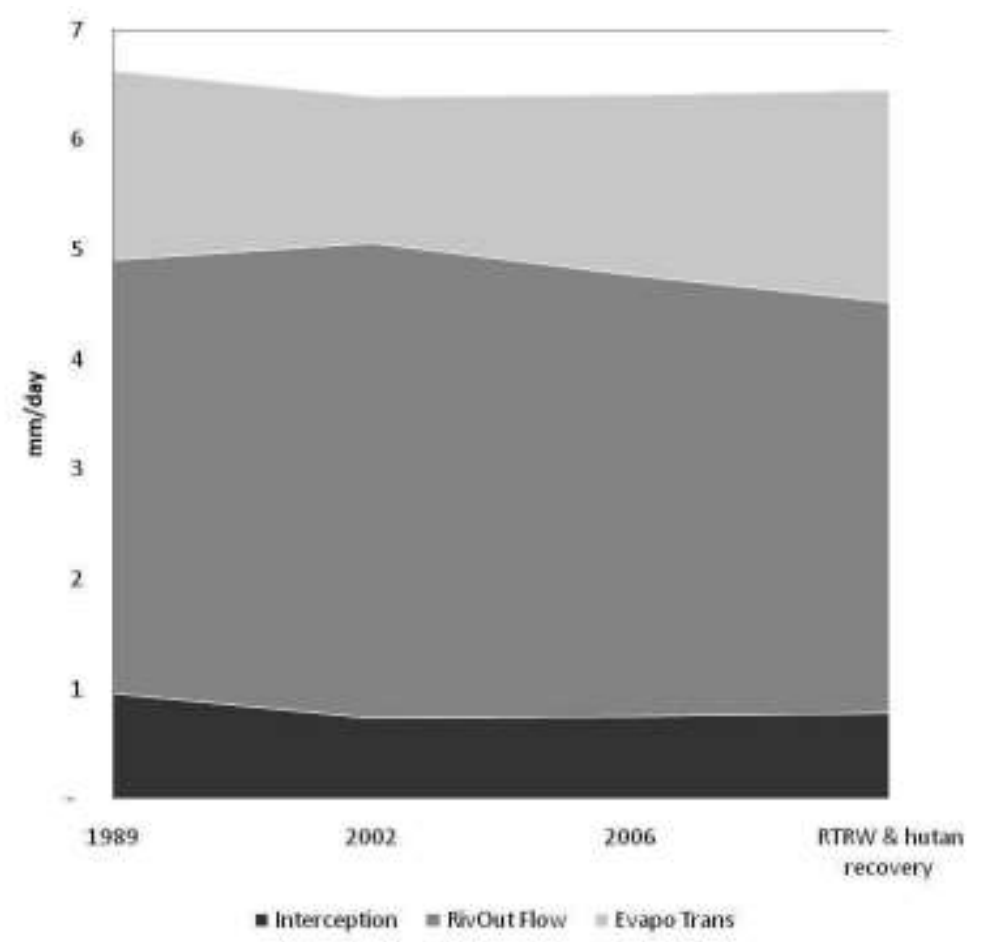

Gambar 5.17. Rata-rata kondisi water ballance pada beberapa skenario penggunaan lahan dan landuse aktual 


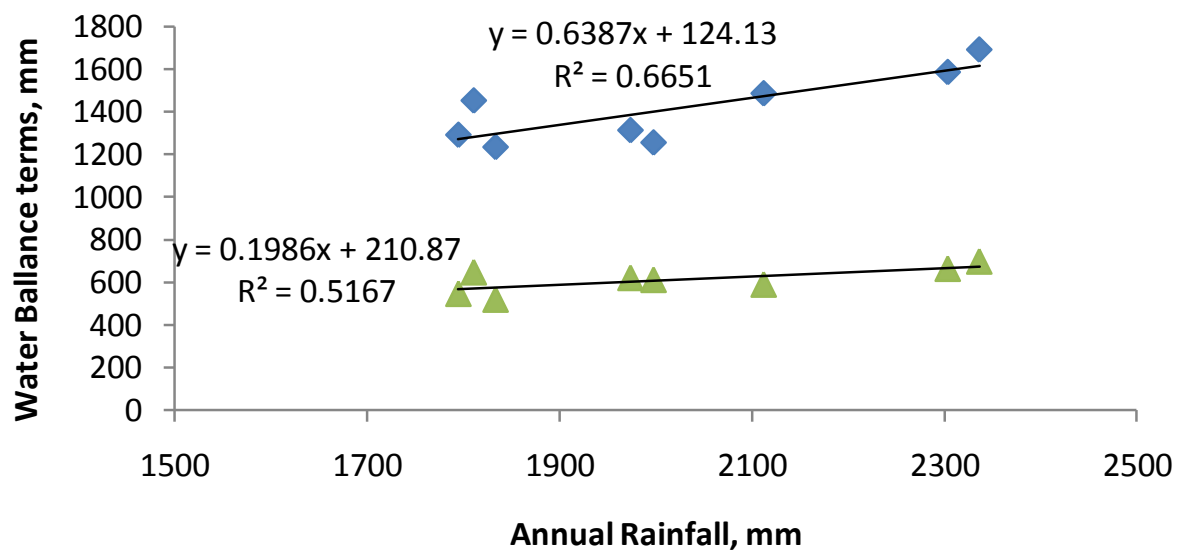

$\begin{array}{ll}- \text { RivlnFlow } & \Delta \text { Evapotrans } \\ - \text { Linear (RivInFlow) } & \text { Linear (Evapotrans) }\end{array}$

Gambar 5.18. Hubungan kondisi water ballance dengan total hujan tahunan 


\section{Pembahasan dan Kesimpulan}

\subsection{Pembahasan}

Setelah mempelajari pandangan atau persepsi masing-masing kelompok LEK, PEK dan MEK melalui metode yang sesuai untuk masing-masing kelompok, kemudian ketiga kelompok tersebut dipertemukan dalam forum sarasehan sehari. Dalam pertemuan bersama ini dihadiri oleh wakil-wakil Kelompok Tani, Kelompok LMDH, HIPPAM, HIPPA, dan tokoh-tokoh masyarakat (Kelompok LEK), wakil-wakil Pemerintah Kota Batu (Bappeda, Dinas Pertanian dan Kehutanan, Dinas Pengairan dan Bina Marga, dan Dinas Lingkungan Hidup (Kelompok PEK), Perum Jasa Tirta I, Tahura R. Soerjo, Perum Perhutani KPH Malang dan Jatim Park/PHRI (Kelompok Perusahaan/PEK), serta dari peneliti Fakultas Pertanian UB Malang (Kelompok MEK).
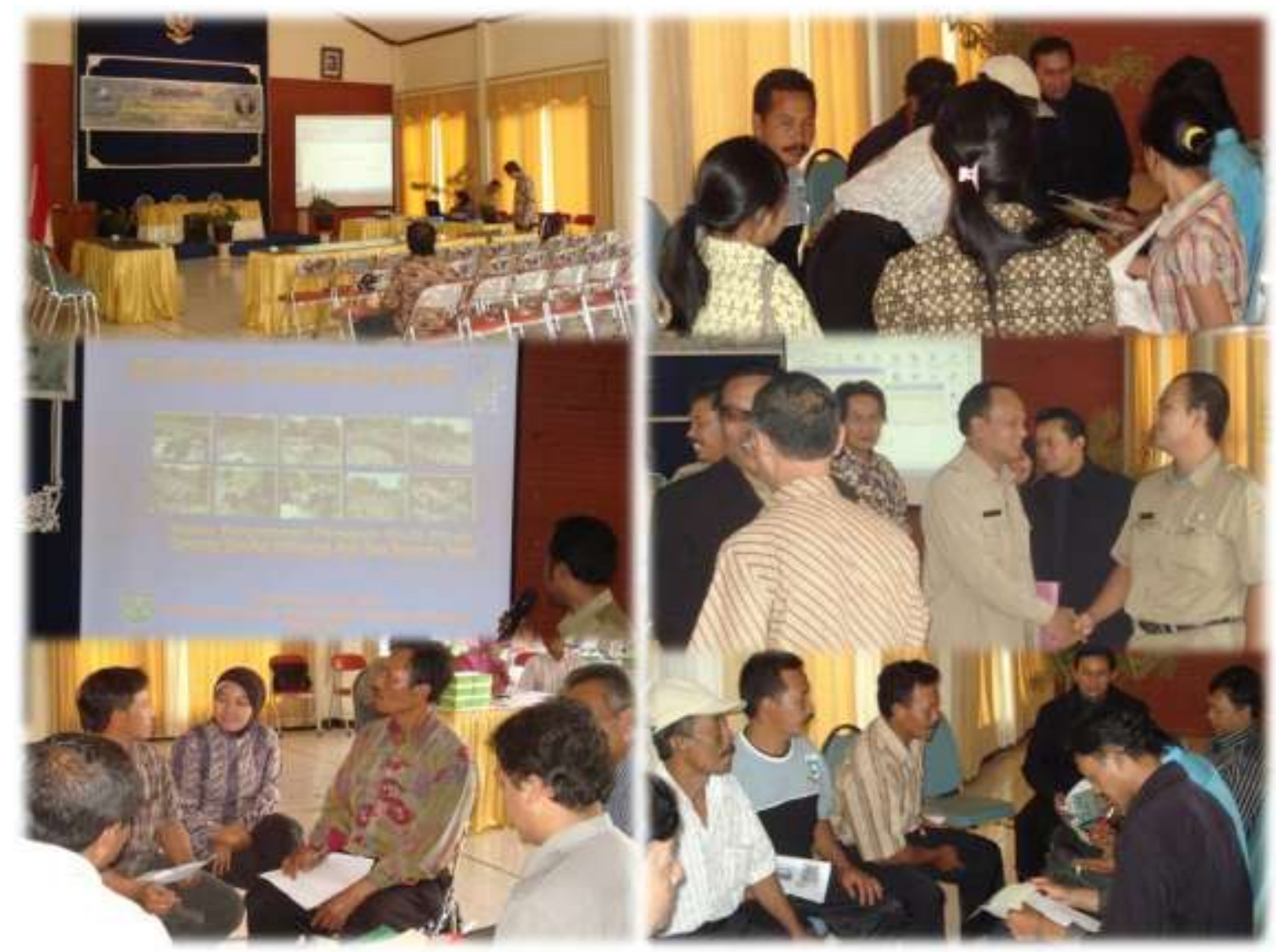

Gambar 6.1. Suasana sarasehan tiga pihak : LEK, PEK dan MEK untuk Pengelolaan DAS Sumber Brantas di Kota Batu 18 Pebruari 2009

Hasil analisis terhadap pandangan ketiga kelompok LEK, PEK dan MEK kemudian dikonfirmasikan dengan pertemuan sarasehan ketiga kelompok itu. Perbandingan kedua hasil 
analisis tadi menunjukkan bahwa terdapat persamaan dan perbedaan pendapat diantara ketiganya, namun secara umum kecenderungan pandangan dari ketiga kelompok itu dapat dikatakan serupa.

Berikut ini diuraikan persamaan dan perbedaan pandangan ketiga kelompok serta bagaimana upaya yang bisa dilakukan untuk membangun kesepahaman diantara mereka.

\subsubsection{Perbandingan Pandangan LEK, PEK dan MEK tentang banjir dan kekeringan}

Secara umum ketiga kelompok LEK, PEK dan MEK sepakat bahwa debit sungai dipengaruhi oleh $\underline{\text { musim }}$ (hujan dan kemarau) dan kondisi hutan (keberadaan pohon-pohonan). Walaupun secara umum persepsinya serupa, tetapi ada beberapa hal detil yang berbeda. Menurut kelompok LEK dan PEK, kondisi hutan ternyata berpengaruh terhadap jumlah air yang tertampung di sungai. Dengan kata lain, jika wilayah hutannya luas, maka bencana banjir juga akan jarang terjadi. Selain itu, dikatakan pula bahwa debit sungai pada musim penghujan dan kemarau sangat jauh berbeda, dimana pada musim hujan debit sungai seringkali sangatlah tinggi sehingga menimbulkan banjir sementara itu pada musim kemarau debit sungai menjadi sangat kecil dan tidak mencukupi kebutuhan air untuk pertanian.

Hasil yang sama juga diperoleh dari proses simulasi dengan model GenRiver oleh kelompok MEK, dimana dari empat skenario penutupan lahan, didapatkan bahwa penutupan lahan dengan prosentase luasan hutan paling kecil yaitu penutupan lahan tahun 2002, menghasilkan fluktuasi debit paling tinggi khususnya pada musim penghujan, dibandingkan dengan penutupan lahan lainnya (gambar 5.17). Fluktuasi debit yang tinggi menandakan adanya kejadian banjir pada hari-hari tertentu setelah adanya kejadian hujan. Hasil perbandingan debit sungai antara musim kemarau dan penghujan menunjukkan bahwa penutupan lahan tahun 2006 dan 2002 menghasilkan proporsi debit sungai pada musim penghujan lebih banyak dibandingkan pada musim kemarau. Hal ini sejalan dengan persepsi masyarakat seperti yang telah diuraikan sebelumnya.

Informasi lain yang didapatkan dari hasil simulasi model menunjukkan bahwa luasan wilayah hutan terkecil (landuse 2002), menghasilkan total debit sungai yang paling besar dalam kurun waktu satu tahun. Sementara itu, jika hutan masih banyak ditemukan (skenario landuse RTRW \& hutan recovery), maka total debit sungai dalam setahun pun relatif lebih kecil. Namun demikian, meskipun total debit pada skenario dengan luas wilayah hutan yang luas ini lebih kecil, tetapi ketersediaan air antara musim penghujan dan kemarau relatif lebih tercukupi dari pada skenario penutupan lahan lainnya. 


\subsubsection{Perbandingan Pandangan LEK, PEK dan MEK tentang jumlah dan debit mata air}

Adanya fenomena menurunnya jumlah mata air yang ada di wilayah DAS Sumber Brantas dari 111 menjadi 58 dikatakan oleh masyarakat lokal (LEK) sebagai akibat dari penggundulan hutan sebagai daerah resapan air, yang terjadi besar-besaran di wilayah ini. Kondisi ini terus memburuk dengan semakin menurunnya debit pada mata air yang masih tersisa. Upaya-upaya yang dapat dilakukan menurut mereka adalah dengan menanami lokasi-lokasi mata air dengan pepohonan besar seperti pohon lo, beringin, pucung, dan sebagainya dan tidak diperbolehkannya menanam tanaman sayur-sayuran (hortikultura) di dekat mata air. Pendapat yang sama pun dikemukakan oleh kelompok PEK. Beberapa program penanaman khususnya di wilayah mata air diprakarsai oleh beberapa instansi yang berkepentingan dengan pelestarian sumberdaya alam (misalnya Dinas SDAE). Namun demikian, menurut kelompok MEK daerah resapan dari suatu mata air tidaklah mudah ditentukan hanya dari lokasi yang berada di dekat mata air tersebut. Kondisi geologi sangat berpengaruh terhadap lokasi resapan suatu mata air. Dengan kata lain, daerah resapan suatu mata air dapat berupa satu wilayah catchment atau bahkan mungkin terletak jauh di balik perbukitan atau pegunungan di sebelahnya. Identifikasi daerah resapan mata air di DAS Sumber Brantas pernah dilakukan melalui studi yang dilakukan oleh Fakultas Pertanian Universitas Brawijaya bersama dengan masyarakat dengan mempergunakan metode geolistrik.

\subsubsection{Perbandingan Pandangan LEK, PEK dan MEK tentang kualitas air}

Pada dasarnya, persepsi terhadap kualitas air oleh ketiga kelompok LEK, PEK, dan MEK adalah sama. Penurunan kualitas air di DAS Sumber Brantas disebabkan oleh dua faktor utama. Faktor pertama adalah adanya erosi dan sedimentasi yang dihasilkan dari lahan-lahan terbuka di daerah hulu. Selain itu, sedimentasi juga dihasilkan dari kejadian-kejadian longsor baik yang terjadi di lahan, tebing-tebing sungai maupun di sepanjang jalan dengan kelerengan tinggi. Faktor kedua yang menyebabkan menurunnya kualitas air di wilayah ini adalah adanya pencemaran dari berbagai macam industri yang ada seperti pabrik jamur, bunga potong, serta hotel dan penginapan.

\subsubsection{Perbandingan Pandangan LEK, PEK dan MEK tentang erosi dan longsor}

Erosi terbesar menurut kelompok LEK berasal dari lahan-lahan hutan dengan kemiringan tinggi yang dikelola oleh pesanggem (tetelan). Erosi ini disebabkan karena lahan-lahan tersebut ditanami dengan tanaman sayuran seperti wortel, kentang, sawi dan sebagainya. Sementara itu, longsor dikatakan banyak terjadi di daerah-daerah pegunungan yang gundul tidak tertanami pohon. Persepsi kelompok LEK tentang erosi dan longsor tersebut tidak jauh berbeda dengan pendapat dari kelompok PEK dan MEK. Perubahan penggunaan lahan 
dengan struktur kanopi rapat menjadi terbuka merupakan faktor pendorong utama terjadinya erosi di wilayah ini. Sementara itu, faktor kelerengan merupakan faktor utama terjadinya longsor di wilayah ini dimana lokasi-lokasi dengan lereng yang tinggi $\left(>60^{\circ}\right)$ mempunyai kemungkinan paling besar untuk terjadi longsor. Sedangkan faktor lain seperti vegetasi merupakan faktor pendorong lain setelah faktor kelerengan. Sebagian besar longsor yang terjadi di DAS Sumber Brantas terjadi di lahan dan jalan.

\subsection{Penerapan Metodologi RHA di DAS Sumber Brantas}

Penerapan metode RHA di DAS Sumber Brantas memakan waktu kurang dari 6 bulan. Meskipun pekerjaan ini telah melebihi 3 bulan dari batas waktu kontrak pekerjaan, namun pada kenyataannya pekerjaan ini baru dimulai sekitar 4.5 bulan setelah penandatanganan kontrak kerja sehingga total waktu yang digunakan untuk mengerjakannya adalah selama 5 bulan. Beberapa kendala, keuntungan serta kekurangan dari pelaksanaan metode RHA di DAS Sumber Brantas dijelaskan pada uraian berikut.

DAS Sumber Brantas yang luasnya sekitar 173,84 km², hampir $95 \%$ terletak dalam wilayah Kota Batu dan sisanya di Kabupaten Malang. Kota Batu merupakan sebuah kawasan otonom yang baru (2001). Dilihat dari kedua aspek ini (luas dan wilayah administrasi) maka sebenarnya DAS Sumber Brantas merupakan sebuah kawasan pengelolaan yang ideal untuk ditangani dalam satu unit pengelolaan. Oleh sebab itu DAS Sumber Brantas merupakan sebuah pilihan lokasi yang ideal untuk uji-coba penerapan metode RHA. DAS Sumber Brantas yang tidak terletak dalam willayah administrasi yang berbeda memberi keuntungan tersendiri khususnya dalam studi LEK dan PEK, karena tidak diperlukan pengulangan responden dari institusi yang sama.

Selain itu, luas DAS yang tidak begitu besar memberikan kemudahan tersendiri dalam studi MEK, apalagi didukung dengan kondisi sistem drainase/hidrologi yang tidak begitu rumit dimana keseluruhan wilayah DAS hanya terbagi dalam subcatchment-subcatchment dengan satu outlet utama (tanpa ada waduk, danau dan lokasi-lokasi penampungan air lainnya). Namun demikian, kelemahan dalam studi MEK yang dilakukan di DAS Sumber Brantas adalah tidak adanya stasiun pengukuran debit yang dapat mengukur debit yang keluar dari DAS ini. Sehingga pada akhirnya proses validasi model dilakukan pada wilayah yang merupakan representasi dari debit yang dikeluarkan di stasiun pengukuran debit Gadang. Wilayah tersebut mencakup DAS Sumber Brantas itu sendiri, DAS Bango, dan Amprong. Bertambah luasnya wilayah ini membawa konsekuensi tersendiri terhadap ketersediaan data baik data hidrologi, tanah maupun spasial yang diperlukan dalam input GenRiver untuk proses validasi model dan juga waktu yang diperlukan untuk menyelesaikan pekerjaan. 
Kelemahan lain dalam penerapan metode RHA ini terletak pada proses simulasi data dalam program GenRiver. Seperti diketahui bahwa karena sifatnya sebagai "rapid appraissal", sebagian besar data yang dipergunakan merupakan data sekunder yang diperoleh dari sumber lain. Oleh karenanya tingkat validitas data yang ada belum dapat sepenuhnya dipastikan oleh peneliti, sehingga diperlukan verifikasi dari data-data yang ada. Proses ini, ditambah dengan dukungan birokrasi dan administrasi dari institusi penyedia data yang belum tentu dapat mempermudah proses penyediaan data merupakan faktor lain yang dapat menghambat analisa data dalam studi MEK. Di sisi lain, GenRiver sebagai model yang dikembangkan oleh tim peneliti ICRAF SEA, memerlukan pemahaman lebih mendalam dari pihak luar yang hanya memahami model ini dibagian luar (kulitnya) saja. Keseluruhan faktor-faktor tersebut yang kemudian berintegrasi menjadi satu, dapat memberikan kemungkinan penerapan metode di lokasi-lokasi lain akan memerlukan waktu lebih lama dari waktu yang ditetapkan (dalam hal ini selama 6 bulan).

\subsection{Peluang Pembayaran Jasa Lingkungan di DAS Sumber Brantas}

Rantai pembayaran jasa lingkungan dimulai dari adanya "pembeli" yang mendapatkan layanan secara nyata yang hanya bisa dirasakan apabila dia membayar harganya. Layanan aktual tersebut hanya dapat diberikan oleh penjual yang telah melakukan upaya menghasilkan jasa tersebut.

Rantai layanan ini disajikan secara skematis dalam Gambar 6.2., dimulai dari kondisi landsekap dibawah pengelolaan/penguasaan petani/Perhutani/Tahura yang akan menjadi penyedia air (kuantitas, kualitas dan kontinyuitas). Air yang dihasilkan digunakan oleh PDAM (Kota Batu dan Kota Malang), HIPPAM (Kota Batu), Perusahaan (Hotel, Restoran, Industri di Kota Batu dan Malang), dan Perum Jasa Tirta 1 yang mengelola air untuk selanjutnya disediakan bagi PLTA (Sengguruh dan Karangkates) dan industri, PDAM, irigasi (di kawasan tengah dan hilir Kali Brantas). 


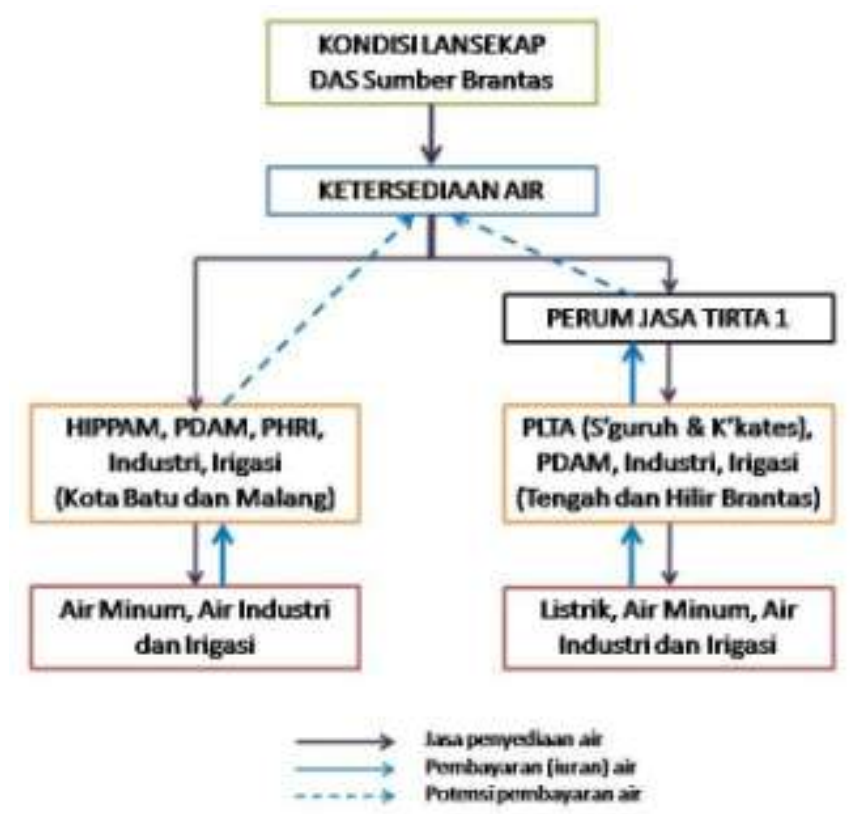

Gambar 6.2. Skema Imbal Jasa Lingkungan di DAS Sumber Brantas

Pada saat ini hampir semua pemanfaat air atau konsumen (kecuali untuk irigasi) sudah "membayar" harga air yang digunakan, walaupun dengan kondisi kualitas, kuantitas dan kontinyuitas yang belum terjamin sepenuhnya. Bentuk-bentuk "gangguan" terhadap penyediaan air yang terkait dengan kualitas, kuantitas dan kontinyuitas sudah mulai lebih sering dirasakan oleh konsumen, misalnya kekurangan air (industri dan PDAM di Surabaya dan sekitarnya), dan pemadaman listrik secara bergilir.

Dalam skema (Gambar 6.2.) ditunjukkan bahwa para konsumen akhir pada saat ini telah membayar harga untuk mendapatkan air atau enerji dari air. Pembayaran oleh konsumen diberikan kepada institusi yang menyediakan air tersebut (PDAM, PLN, HIPPAM). Sementara di DAS Sumber Brantas terdapat institusi yang langsung mengambil air dari sungai/mata air, khususnya di wilayah Kota Batu dan Kota Malang dan institusi yang mendapat air yang sudah dikelola oleh Perum Jasa Tirta 1. Mekanisme yang kedua, di mana institusi penyedia air/enerji memperoleh air dari PJT I, telah melakukan prinsip-prinsip imbal jasa lingkungan secara terbatas.

Sampai sejauh ini, PJT 1 telah menerima hasil "penjualan" air dari konsumennya, terutama dari PJB (Pembangkit PLN Jawa-Bali), PDAM Surabaya, kalangan Industri besar sepanjang Kali Brantas mulai dari Malang sampai Surabaya. Sementara untuk konsumen lain yang cukup besar adalah petani dan petambak sempai sejauh ini mendapat alokasi air Kali Brantas secara gratis. PJT berkewajiban menyediakan air kepada semua konsumennya secara kontinyu sebanyak yang disepakati bersama dan pada kualitas yang memadai. Hasil "penjualan” air oleh PJT 1 sebagian besar dialokasikan untuk pemeliharaan bangunanbangunan dan infrastruktur pendukung di sepanjang Kali Brantas. Sebagian kecil dari hasil itu juga mulai dialokasikan untuk pemeliharaan daerah tangapan air Kali Brantas. 
Sampai sejauh ini, mekanisme imbal jasa lingkungan yang dikembangkan melalui PJT masih dalam lingkup yang agak terbatas. PJT sebagai sebuah BUMN yang berbentuk Perusahaan Umum (Perum) masih belum bisa diterima oleh seluruh stakeholder yang terkait dengan pemanfaatan air. Studi yang dilakukan bersama oleh YPP-LP3ES-PJT I (Gunawan et al., 2006) menunjukkan bahwa masih banyak stakeholder (konsumen) yang belum bersedia mengikuti mekanisme yang dikembangkan melalui PJT dengan berbagai argumentasinya, walaupun sudah diatur dalam undang-undang. Keinginan sebagian stakeholder (konsumen) adalah menggunakan sebuah badan pengelola non-pemerintah yang dianggap lebih netral. Pada saat ini PJT I bekerja sama dengan beberapa pihak (masyarakat, Pemerintah Kota dan/atau Kabupaten dan LSM) sedang menguji-cobakan mekanisme pembayaran jasa kepada masyarakat (petani) yang melakukan praktek-praktek konservasi air. Selain PJT I, ada beberapa perusahaan besar swasta yang juga sedang mencoba melakukan mekanisme imbal jasa lingkungan di kawasan DAS Kali Brantas, misalnya PT Sampoerna, PDAM Kota Malang, PT Unilever, dsb.

Konsumen tersebut di atas seringkali tidak mendapatkan air dalam jumlah dan kualitas yang sesuai dengan kebutuhannya. Kondisi yang sering diungkap misalnya kekurangan air di musim kemarau untuk PLTA dan PDAM (termasuk kualitasnya). Perum Jasa Tirta I tidak mampu menyediakan karena adanya gangguan baik oleh alam maupun manusia. Gangguan alam misalnya pola musim kemarau dan hujan yang ekstreem di luar perkiraan. Gangguan oleh manusia misalnya pencemaran air sungai karena aktivitas manusia membuah limbah ke sungai baik dari domestik maupun industri yang tidak bisa dikendalikan. Gangguan lainnya berasal dari kombinasi keduanya ulah manusia dan kondisi alam, misalnya pendangkalan waduk karena sedimentasi sebagai akibat tindakan manusia menggunakan lahan di bagian hulu DAS secara tak terkendali (penggundulan lahan, pengolahan tanah intensif, dsb).

Pendangkalan waduk-waduk yang dibangun di sepanjang Kali Brantas mengakibatkan kapasitas waduk menurun (Perum Jasa Tirta I, 2005), sehingga jumlah air yang ditampung selama musim penghujan tidak mencukupi untuk kebutuhan PLTA pada musim kemarau. Oleh karena itu, PJT I juga memiliki kepentingan besar terhadap pengelolaan lahan di bagian hulu DAS Kali Brantas, termasuk DAS Sumber Brantas. Adanya gangguan-ganguan terhadap kualitas, kuantitas dan kontinyuitas produk-produk yang dihasilkan oleh berbagai stakeholder tersebut pada akhirnya juga sampai ke masyarakat sebagai konsumen akhir. Konsumen akhir seperti rumah tangga yang menggunakan air bersih PDAM dan listrik dari PLN seringkali merasa terganggu dengan adanya suplai air PDAM yang kualitasnyan tidak layak dan tidak lancar dan gangguan listrik yang sering mati.

Pada saat ini sebagian konsumen akhir tampaknya bersedia membayar lebih banyak dari apa yang sekarang mereka keluarkan untuk mendapatkan air dan enerji listrik. Konsumen berani membayar harga lebih mahal untuk membeli air bersih (air minum) berupa air kemasan, 
dengan alasan kualitas. Banyak konsumen juga menggunakan generator sendiri untuk memperoleh listrik dengan membeli BBM ketika listrik dari PLN mati. Sementara petanipetani di Kota Batu mengambil air dari sungai dan mata air dengan menggunakan pompa air dan diangkut dengan kendaraan untuk menyiram tanamannya. Upaya-upaya tersebut membuktikan bahwa sebagian konsumen ternyata sudah bersedia membayar lebih untuk memperoleh layanan yang lebih baik.

Potensi ini pembeli jasa lingkungan khususnya sumberdaya air di DAS Kali Brantas pada umumnya dan DAS Sumber Brantas khusunya adalah sangat besar. Sementara Pemerintah Daerah dan DPRD Provinsi Jawa Timur tengah menyiapkan peraturan daerah (PERDA) tentang mekanisme imbal jasa lingkungan antara hulu-hilir, maka hasil studi RHA ini dapat dipakai sebagai dasar pengembangan mekanisme ini di DAS Sumber Brantas.

Pemahaman yang sama dari berbagai pihak tentang hubungan antara kualitas, kuantitas dan kontinyuitas penyediaan air berhubungan dengan kondisi lahan di hulu atau daerah tangkapan air, bisa dipakai menjadi dasar pengembangan mekanisme imbal jasa lingkungan ini. Adanya perbedaan terhadap detil proses masing-masing bisa menjadi bahan dialog selanjutnya dalam rangka membangun kemitraan oleh semua pihak. Landasan untuk menjalankan proses ini di DAS Sumber Brantas sebenarnya sudah dibangun melalui berbagai kegiatan yang dilakukan oleh berbagai pihak dalam beberapa tahun terakhir ini. Walaupun hasilnya masih sangat beragam tetapi proses pengembangan mekanisme imbal jasa lingkungan di DAS Sumber Brantas dan DAS Kali Brantas pada umumnya, sudah layak untuk dikembangkan lebih konkrit lagi.

Dalam pertemuan antar pihak yang dilaksanakan dalam rangka RHA ini, terungkap adanya kebutuhan yang sangat mendasar jika akan menerapkan mekanisme imbal jasa lingkungan atau yang sduah dikenal oleh masyarakat dengan istilah "hulu-hilir". Masalah-masalah yang diungkapkan itu sesuai dengan salah satu prinsip imbal jasa yaitu "bagaimana membuat pembeli yakin bahwa layanan yang diberikan sesuai dengan yang dijanjikan". Salah satunya adalah bagaimana membuktikan berbagai kualitas servis atau layanan, misalnya :

- Bagaimana mengukur hasil air atau debit air yang dihasilkan oleh DAS Sumber Brantas dan kontribusi setiap SubDAS sampai DAS Mikro yang ada didalamnya supaya bisa memberikan reward kepada petani secara adil ? Sampai saat ini belum ada pengukuran-pengukuran debit di kawasan ini. Siapa yang akan mengukur dan memonitor?

- Terkait dengan kualitas air, sebenarnya sudah ada upaya pengukuran oleh PJT dan masyarakat. Namun karena biaya analisis air sangat mahal dan jumlah sampel yang banyak (untuk memonitor secara "kontinyu") maka monitoring kualitas yang dilakukan tidak memadai. Pengembangan monitoring kualitas dengan metode biologi 
dan pelibatan stakeholder (kelompok masyarakat, anak sekolah) sudah dicoba tetapi belum mempunyai sasaran yang jelas sehingga tidak berjalan dengan konsisten.

Selain itu juga masih ada beberapa persoalan lain yang belum dapat disepakati oleh berbagai pihak yang terlibat dalam mekanisme hulu-hilir ini, diantaranya adalah:

- Siapa yang paling layak untuk menjadi perantara dalam mekanisme ini dan bisa diterima oleh semua stakeholder belum dapat dirumuskan dengan jelas. Sudah ada inisiasi pembentukan Forum DAS Brantas namun masih belum jelas ke mana arahnya. Demikian pula ada keinginan untuk membentuk forum-forum DAS di level bawahnya (Sub DAS sampai DAS Mikro), tetapi juga belum ada kesepakatan ke mana visi dan misi nya.

- Konsep alokasi air bagi pemakai atau konsumen pada umumnya sudah agak jelas dan mudah dipahami serta diperhitungkan oleh semua pihak. Sebaliknya konsep kontribusi petani hulu terhadap hasil air masih sulit untuk dipahami. MEK melalui simulasi model seperti GenRiver yang diterapkan dalam studi RHA di DAS Sumber Brantas ini juga belum bisa memberikan solusi yang cukup detil terhadap persoalan ini.

- Hubungan antara jenis tanaman (semusim versus tahunan/pohon) dengan fungsi hodrologi secara umum sudah ada kesepahaman diantara semua stakeholder. Namun, hubungan yang lebih detil misalnya tentang jenis pohon apa yang mampu meningkatkan hasil air, di mana lokasi penanaman yang tepat (misalnya untuk mempertahankan mata air), dsb masih belum ada kesepakatan. Salah satu isu sedang hangat di DAS Sumber Brantas adalah konversi tanaman sayuran di kawasan hutan dengan tanaman kopi robusta yang ditanam dibawah tegakan.

\subsection{Kesimpulan}

Berdasarkan hasil penelitian RHA di DAS Sumber Brantas yang dilakukan dengan melibatkan masyarakat lokal, pemerintah daerah dan lembaga swasta, lembaga nonpemerintah dan perguruan tinggi di Kota Batu, maka dapat disimpulkan:

1. Terdapat kesamaan pemahaman dari tiga pihak (LEK, PEK dan MEK) tentang fungsi hidrologi dan pengelolaan DAS Sumber Brantas terutama hal-hal yang bersifat umum, misalnya hubungan antara hutan, penebangan pohon dan debit sungai (banjir dan kekeringan). Perbedaan terhadap hal-hal detil memang ada dan belum semua bisa disatukan.

2. Berdasarkan skenario simulasi model dampak pengelolaan lahan terhadap fungsi hidrologi DAS Sumber Brantas, hasil yang terbaik adalah jika seluruh kawasan 
"hutan" yang sebagian besar menjadi lahan pertanian tanaman semusim dikembalikan menjadi hutan (reforestasi) dan hutan tanaman (agro-forestri), sementara kawasan budidaya dengan kelerengan $>60^{\circ}$ juga ditanami dengan tanaman tahunan (agroforestri).

3. Ada beberapa faktor yang cukup kuat untuk digunakan sebagai dasar dalam mengembangkan mekanisme imbal-jasa lingkungan antara hulu-hilir di DAS Sumber Brantas. Selain itu di Kota Batu juga sudah ada proses pendahuluan yang bisa dipakai sebagai rujukan jika akan melaksanakan mekanisme imbal jasa lingkungan. 


\section{Daftar Pustaka}

Anonimous. 2006. Studi Bufferzone Pengamanan Sumberdaya Strategis di DAS Sumber Brantas. Laporan Akhir. Dinas Permukiman, Pemerintah Propinsi Jatim, Surabaya.

Anonimous. 2006. Studi Detil Konservasi Sub DAS Sumber Brantas. Laporan Akhir PT Ika Adya Perkasa. Induk Pelaksana Kegiatan Pengembangan Wilayah Sungai Kali Brantas, Direktorat Jendral Sumberdaya Air, Departemen Pekerjaan Umum.

Anonimous. 2007. Studi Kajian Hidrologi Kawasan DAS Sumber Brantas. Laporan Akhir. Dinas Permukiman, Pemerintah Propinsi Jatim, Surabaya.

Environmental Service Program (ESP). 2006. Quarterly Report No. 7. October-December 2006. Development Alternatives, Inc. for the USAID. p. 43-44.

Farida, K. Jeanes, D. Kurniasari, A. Widayati, A. Ekadinata, D. Prasetyo Hadi, L. Joshi, D. Suyamto and M. van Noordwijk. 2005. Rapid Hydrological Appraisal (RHA) of Singkarak Lake in the context of Rewarding Upland Poor for Environmental Services (RUPES). Working Paper 2005, ICRAF Southeast Asia, Bogor.

Fokal Mesra. 2008. Penguatan Pengorganisasian dan Leveraging Kelompok Masyara-kat dalam rangka Konservasi Lingkungan dan Sumberdaya Air DAS Sum-ber Brantas Kota Batu. Laporan Kegiatan Forum Kajian Air dan Lingkungan menuju Selaras Alam (Fokal Mesra). Environmental Service Program (ESP) - USAID.

Gunawan, Pandriono, and R.Y. Kristiawati. 2005. Action Research on Development Upstream-Downstream Transaction for Watershed Protection Services and Improved Livelihoods. Final Report. IIED-LP3ES-YPP-JASA TIRTA I.

Handayani, et al. 2001.Penentuan Status Kualitas Perairan Sungai Sumber Brantas dengan Biomonitoring Makrozoobentos : Tinjauan dari Pencemaran Bahan Organik. Biosain Vol. 1 No. 1, April 2001.

Jeanes, K. M. van Noordwijk, L. Joshi, A. Widayati, Farida and B. Leimona. 2006. Rapid Hydrological Appraisal in the Context of Environmental Service Rewards. World Agroforestry Centre, ICRAF Southeast Asia, Bogor, Indonesia.

Nugroho, N.P., C.N.S. Priyono, dan S.A. Cahyono. 2004. Dampak Sosial, Ekonomi dan Ekologi Pengelolaan Hutan Pinus. Prosiding Ekspose BP2TPDAS-IBB Surakarta di Kebumen 3 Agustus 2004.

Paguyuban LMDH Kota Batu dan Kelompok Petani Bumi Jaya. 2008. Pengembangan Usaha Pembibitan Permanen Berbasis Masyarakat Lembaga Desa Hutan (LMDH). Laporan Akhir. Environmental Service Program (ESP) - USAID.

Pemerintah Provinsi Jawa Timur. 2006. Peraturan Daerah Provinsi Jawa Timur Nomor 02 Tahun 2006 tentang Rencana Tata Ruang Wilayah Provinsi Jawa Timur. 
Perum Jasa Tirta (PJT) I. 2005. Tinjauan Hidrologi dan Sedimentasi DAS Kali Sumber Brantas. Paper disampaikan pada Diskusi Terbatas tentang "Masalah dan Model Penanganan Lahan Kritis di Jawa Timur", Balitbang Provinsi Jawa Timur tanggal 15 Nopember 2005.

PPLH UB. 2008. Semilokas Sehari DAS Brantas. Masalah dan Solusinya. Malang 24 Juli 2008.

Priyono, C.N.S. 2003. Pengaruh Hutan Pinus terhadap Erosi dan Tata Air. Prosiding Diskusi Panel "Menyikapi Kerusakan Sumberdaya Alam dengan Pendekatan Pengelolaan Daerah Aliran Sungai”, di Trenggalek 20 Januari 2003. BP2TPDAS, Badan Litbang Kehutanan, Departemen Kehutanan, Surakarta.

Santoso, S dan Suwarti, T. Geologi Lembar Malang, Jawa. 1992. Pusat Penelitian dan Pengembangan Geologi Departemen Pertambangan dan Energi, Dirjen Geologi dan Sumberdasya Mineral.

Serikat Petani Gunung Biru (SPGB). 2008. Restorasi Kawasan Hutan Wengkon : Model Pengorganisasian Masyarakat serta Pengembangan Tanaman di bawah Tegakan yang sesuai. Laporan Akhir. Environmental Service Program (ESP) - USAID. 


\section{WORKING PAPERS IN THIS SERIES}

2005

1. Agroforestry in the drylands of eastern Africa: a call to action

2. Biodiversity conservation through agroforestry: managing tree species diversity within a network of community-based, nongovernmental, governmental and research organizations in western Kenya.

3. Invasion of prosopis juliflora and local livelihoods: Case study from the Lake Baringo area of Kenya

4. Leadership for change in farmers organizations: Training report: Ridar Hotel, Kampala, 29th March to 2nd April 2005.

5. Domestication des espèces agroforestières au Sahel : situation actuelle et perspectives

6. Relevé des données de biodiversité ligneuse: Manuel du projet biodiversité des parcs agroforestiers au Sahel

7. Improved land management in the Lake Victoria Basin: TransVic Project's draft report.

8. Livelihood capital, strategies and outcomes in the Taita hills of Kenya

9. Les espèces ligneuses et leurs usages: Les préférences des paysans dans le Cercle de Ségou, au Mali

10. La biodiversité des espèces ligneuses: Diversité arborée et unités de gestion du terroir dans le Cercle de Ségou, au Mali

2006

11. Bird diversity and land use on the slopes of Mt. Kilimanjaro and the adjacent plains, Tanzania

12. Water, women and local social organization in the Western Kenya Highlands

13. Highlights of ongoing research of the World Agroforestry Centre in Indonesia

14. Prospects of adoption of tree-based systems in a rural landscape and its likely impacts on carbon stocks and farmers' welfare: The FALLOW Model Application in Muara Sungkai, Lampung, Sumatra, in a 'Clean Development Mechanism' context

15. Equipping integrated natural resource managers for healthy agroforestry landscapes.

16. Are they competing or compensating on farm? Status of indigenous and exotic tree species in a wide range of agro-ecological zones of Eastern and Central Kenya, surrounding Mt. Kenya. 
17. Agro-biodiversity and CGIAR tree and forest science: approaches and examples from Sumatra.

18. Improving land management in eastern and southern Africa: A review of polices.

19. Farm and household economic study of Kecamatan Nanggung, Kabupaten Bogor, Indonesia: A socio-economic base line study of agroforestry innovations and livelihood enhancement.

20. Lessons from eastern Africa's unsustainable charcoal business.

21. Evolution of RELMA's approaches to land management: Lessons from two decades of research and development in eastern and southern Africa

22. Participatory watershed management: Lessons from RELMA's work with farmers in eastern Africa.

23. Strengthening farmers' organizations: The experience of RELMA and ULAMP.

24. Promoting rainwater harvesting in eastern and southern Africa.

25. The role of livestock in integrated land management.

26. Status of carbon sequestration projects in Africa: Potential benefits and challenges to scaling up.

27. Social and Environmental Trade-Offs in Tree Species Selection: A Methodology for Identifying Niche Incompatibilities in Agroforestry [Appears as AHI Working Paper no. 9]

28. Managing tradeoffs in agroforestry: From conflict to collaboration in natural resource management. [Appears as AHI Working Paper no. 10]

29. Essai d'analyse de la prise en compte des systemes agroforestiers pa les legislations forestieres au Sahel: Cas du Burkina Faso, du Mali, du Niger et du Senegal.

30. Etat de la recherche agroforestière au Rwanda etude bibliographique, période 19872003

31. Science and technological innovations for improving soil fertility and management in Africa: A report for NEPAD's Science and Technology Forum.

32. Compensation and rewards for environmental services.

33. Latin American regional workshop report compensation.

34 Asia regional workshop on compensation ecosystem services.

35 Report of African regional workshop on compensation ecosystem services.

36 Exploring the inter-linkages among and between compensation and rewards for ecosystem services CRES and human well-being 
37 Criteria and indicators for environmental service compensation and reward mechanisms: realistic, voluntary, conditional and pro-poor

38 The conditions for effective mechanisms of compensation and rewards for environmental services.

39 Organization and governance for fostering Pro-Poor Compensation for Environmental Services.

40 How important are different types of compensation and reward mechanisms shaping poverty and ecosystem services across Africa, Asia \& Latin America over the Next two decades?

41. Risk mitigation in contract farming: The case of poultry, cotton, woodfuel and cereals in East Africa.

42. The RELMA savings and credit experiences: Sowing the seed of sustainability

43. Yatich J., Policy and institutional context for NRM in Kenya: Challenges and opportunities for Landcare.

44. Nina-Nina Adoung Nasional di So! Field test of rapid land tenure assessment (RATA) in the Batang Toru Watershed, North Sumatera.

45. Is Hutan Tanaman Rakyat a new paradigm in community based tree planting in Indonesia?

46. Socio-Economic aspects of brackish water aquaculture (Tambak) production in Nanggroe Aceh Darrusalam.

47. Farmer livelihoods in the humid forest and moist savannah zones of Cameroon.

48. Domestication, genre et vulnérabilité : Participation des femmes, des Jeunes et des catégories les plus pauvres à la domestication des arbres agroforestiers au Cameroun.

49. Land tenure and management in the districts around Mt Elgon: An assessment presented to the Mt Elgon ecosystem conservation programme.

50. The production and marketing of leaf meal from fodder shrubs in Tanga, Tanzania: A pro-poor enterprise for improving livestock productivity.

51. Buyers Perspective on Environmental Services (ES) and Commoditization as an approach to liberate ES markets in the Philippines.

52. Towards Towards community-driven conservation in southwest China: Reconciling state and local perceptions.

53. Biofuels in China: An Analysis of the Opportunities and Challenges of Jatropha curcas in Southwest China.

54. Jatropha curcas biodiesel production in Kenya: Economics and potential value chain development for smallholder farmers 
55. Livelihoods and Forest Resources in Aceh and Nias for a Sustainable Forest Resource Management and Economic Progress.

56. Agroforestry on the interface of Orangutan Conservation and Sustainable Livelihoods in Batang Toru, North Sumatra.

\section{8}

57. Assessing Hydrological Situation of Kapuas Hulu Basin, Kapuas Hulu Regency, West Kalimantan.

58. Assessing the Hydrological Situation of Talau Watershed, Belu Regency, East Nusa Tenggara.

59. Kajian Kondisi Hidrologis DAS Talau, Kabupaten Belu, Nusa Tenggara Timur.

60. Kajian Kondisi Hidrologis DAS Kapuas Hulu, Kabupaten Kapuas Hulu, Kalimantan Barat.

61. Lessons learned from community capacity building activities to support agroforest as sustainable economic alternatives in Batang Toru orang utan habitat conservation program (Martini, Endri et al.)

62. Mainstreaming Climate Change in the Philippines.

63. A Conjoint Analysis of Farmer Preferences for Community Forestry Contracts in the Sumber Jaya Watershed, Indonesia.

64. The Highlands: A shower water tower in a changing climate and changing Asia.

65. Eco-Certification: Can It Deliver Conservation and Development in the Tropics?

66. Designing ecological and biodiversity sampling strategies. Towards mainstreaming climate change in grassland management.

67. Participatory Poverty and Livelihood Assessment Report, Kalahan, Nueva Vizcaya, the Philippines

68. An Assessment of the Potential for Carbon Finance in Rangelands

69. ECA Trade-offs Among Ecosystem Services in the Lake Victoria Basin.

70. Le business plan d'une petite entreprise rurale de production et de commercialisation des plants des arbres locaux. Cas de quatre pépinières rurales au Cameroun.

71. Les unités de transformation des produits forestiers non ligneux alimentaires au Cameroun. Diagnostic technique et stratégie de développement Honoré Tabuna et Ingratia Kayitavu.

72. Les exportateurs camerounais de safou (Dacryodes edulis) sur le marché sous régional et international. Profil, fonctionnement et stratégies de développement. 
73. Impact of the Southeast Asian Network for Agroforestry Education (SEANAFE) on agroforestry education capacity.

74. Setting landscape conservation targets and promoting them through compatible land use in the Philippines.

75. Review of methods for researching multistrata systems.

76. Study on economical viability of Jatropha curcas L. plantations in Northern Tanzania Assessing farmers' prospects via cost-benefit analysis

77. Cooperation in Agroforestry between Ministry of Forestry of Indonesia and International Center for Research in Agroforestry

78. "China's bioenergy future. an analysis through the Lens if Yunnan Province

79. Land tenure and agricultural productivity in Africa: A comparative analysis of the economics literature and recent policy strategies and reforms

80. Boundary organizations, objects and agents: linking knowledge with action in agroforestry watersheds

81. Reducing emissions from deforestation and forest degradation (REDD) in Indonesia: options and challenges for fair and efficient payment distribution mechanisms

82. Mainstreaming Climate Change into Agricultural Education: Challenges and Perspectives.

83. Challenging Conventional mindsets and disconnects in Conservation: the emerging role of eco-agriculture in Kenya's Landscape Mosaics.

84. Lesson learned RATA garut dan bengkunat: suatu upaya membedah kebijakan pelepasan kawasan hutan dan redistribusi tanah bekas kawasan hutan.

85. The emergence of forest land redistribution in Indonesia.

86. Commercial opportunities for fruit in Malawi.

87. Status of fruit production processing and marketing in Malawi.

88. Fraud in tree science.

89. Trees on farm: analysis of global extent and geographical patterns of agroforestry

90. The springs of Nyando: water, social organization and livelihoods in Western Kenya.

91. Building cpacity toward region-wide curriculum and teaching materials development in agroforestry education in Southeast Asia.

92. Overview of Biomass Energy Technology in Rural Yunnan.

93. A Pro-Growth Pathway for Reducing Net GHG Emissions in China 
94. Analysis of local livelihoods from past to present in the central Kalimantan Ex-Mega Rice Project area

95. Constraints and options to enhancing production of high quality feeds in dairy production in Kenya, Uganda and Rwanda

96. Agroforestry education in the Philippines: status report from the Southeast Asian Network for Agroforestry Education (SEANAFE)

\section{0}

97. Economic viability of Jatropha curcas L. plantations in Northern Tanzaniaassessing farmers' prospects via cost-benefit analysis.

98. Hot spot of emission and confusion: land tenure insecurity, contested policies and competing claims in the central Kalimantan Ex-Mega Rice Project area

99. Agroforestry competences and human resources needs in the Philippines

100.CES/COS/CIS paradigms for compensation and rewards to enhance environmental Services

101. Case study approach to region-wide curriculum and teaching materials development in agroforestry education in Southeast Asia

102. Stewardship agreement to reduce emissions from deforestation and degradation (REDD): Lubuk Beringin's Hutan Desa as the first village forest in Indonesia

103.Landscape dynamics over time and space from ecological perspective

104. A performance-based reward for environmental services: an action research case of "RiverCare" in Way Besai sub-watersheds, Lampung, Indonesia

105. Smallholder voluntary carbon scheme: an experience from Nagari Paningahan, West Sumatra, Indonesia

106. Rapid Carbon Stock Appraisal (RACSA) in Kalahan, Nueva Vizcaya, Philippines.

107. Tree domestication by ICRAF and partners in the Peruvian Amazon: lessons learned and future prospects in the domain of the Amazon Initiative ecoregional program

108. Memorias del Taller Nacional: "Iniciativas para Reducir la Deforestación en la region Andino - Amazónica”, 09 de Abril del 2010. Proyecto REALU Peru

109.Percepciones sobre la Equidad y Eficiencia en la cadena de valor de REDD en Perú -Reporte de Talleres en Ucayali, San Martín y Loreto, 2009. Proyecto REALU-Perú. 
110. Reducción de emisiones de todos los Usos del Suelo. Reporte del Proyecto REALU Perú Fase 1

111.Programa Alternativas a la Tumba-y-Quema (ASB) en el Perú. Informe Resumen y Síntesis de la Fase II. 2da. versión revisada

112.Estudio de las cadenas de abastecimiento de germoplasma forestal en la amazonía Boliviana

113. Biodiesel in the Amazon

114.Estudio de mercado de semillas forestales en la amazonía Colombiana

115.Estudio de las cadenas de abastecimiento de germoplasma forestal en Ecuador

116. How can systems thinking, social capital and social network analysis help programs achieve impact at scale?

117.Energy policies, forests and local communities in the Ucayali Region, Peruvian Amazon

118. NTFPs as a Source of Livelihood Diversification for Local Communities in the Batang Toru Orangutan Conservation Program

119.Studi Biodiversitas: Apakah agroforestry mampu mengkonservasi keanekaragaman hayati di DAS Konto?

120.Estimasi Karbon Tersimpan di Lahan-lahan Pertanian di DAS Konto, Jawa Timur 



\section{Who we are}

The World Agroforestry Centre is the international leader in the science and practice of integrating 'working trees' on small farms and in rural landscapes. We have invigorated the ancient practice of growing trees on farms, using innovative science for development to transform lives and landscapes.

\section{Our vision}

Our Vision is an 'Agroforestry Transformation' in the developing world resulting in a massive increase in the use of working trees on working landscapes by smallholder rural households that helps ensure security in food, nutrition, income, health, shelter and energy and a regenerated environment.

\section{Our mission}

Our mission is to advance the science and practice of agroforestry to help realize an 'Agroforestry Transformation' throughout the developing world.

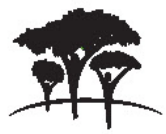

United Nations Avenue, Gigiri - PO Box 30677 - 00100 Nairobi, Kenya Tel: +254 207224000 or vla USA +1 6508336645

Fax: +254 207224001 or via USA +1 6508336646

Southeast Asia Regional Programme - Sindang Barang, Bogor 16680

PO Box161 Bogor 16001, Indonesia

Tel: +62 2518625415 - Fax: +62 2518625416

www.worldagroforestry.org 